\title{
GAMMA SPECTROSCOPIC EXAMINATION OF PEACH BOTTOM HTGR CORE COMPONENTS
}

\author{
by \\ J. F. HOLZGRAF, F. MCCORD, and C. F. WALLROTH \\ $\Delta$ \\ - \\ NOTICE

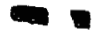 \\ ability. \\ Prepared under \\ Contract EY-76-C-03-0167 \\ Project Agreement No. 56 \\ for the San Francisco Operations Office \\ Department of Energy and the \\ Electric Power Research Institute
}

POPTIONS OFTHISTEPOAMEMUECIBLE IL has been reproduced from the best available copy to permit the broadest possible arail

GENERAL ATOMIC PROJECT 3238

DATE PUBLISHED: APRIL 1978

NoTICE -

This report was prepared as an account of work sponsored by the United States Government. Neither

United States nor the United States Departmert the

Energy, nor any of their emroloyees, Dor any of the

contractors, subcontractors, or their employ of their

any warranty, express or implied, or agues, makes

liability or responsibility for the accuracy, com any legal

of usefulness of any information, appary, preteness process disclosed, or represents that is useduct or infringe privately owned rights.

\section{GENERAL ATOMIC COMPANY}




\section{DISCLAIMER}

This report was prepared as an account of work sponsored by an agency of the United States Government. Neither the United States Government nor any agency Thereof, nor any of their employees, makes any warranty, express or implied, or assumes any legal liability or responsibility for the accuracy, completeness, or usefulness of any information, apparatus, product, or process disclosed, or represents that its use would not infringe privately owned rights. Reference herein to any specific commercial product, process, or service by trade name, trademark, manufacturer, or otherwise does not necessarily constitute or imply its endorsement, recommendation, or favoring by the United States Government or any agency thereof. The views and opinions of authors expressed herein do not necessarily state or reflect those of the United States Government or any agency thereof. 


\section{DISCLAIMER}

Portions of this document may be illegible in electronic image products. Images are produced from the best available original document. 
This report was prepared as an account of work sponsored by the United States Government. Neither the United States nor the Department of Energy, nor any of their employees, nor any of their contractors, subcontractors, or their employees, makes any warranty, express or implied, or assumes any legal liability or responsibility for the accuracy, completeness or usefulness of any information, apparatus, product or process disclosed, or represents that its use would not infringe privately owned rights.

Printed in the United States of America Available from

National Technical Information Service

U.S. Department of Commerce 5285 Port Royal Road

Springfield, Virginia 22161

Price: Printed Copy $\$ 8.00$; Microfiche $\$ 3.00$ 

FOREWORD

Peach Bottom Atomic Power Station Unit No. 1 was the first installation of a High-Temperature Gas-Cooled Reactor (HTGR) in the United States. Power operation began in January 1967 and commercial operation on June 1, 1967. The plant was operated successfully through October 31,1974 , when it was shut down for decommissioning.

In March 1975, the Peach Bottom End-of-Life Program, cosponsored by ERDA and EPRI, was initiated. The prime objective of this program is to validate specific HTGR design codes and predictions by comparison of actual and predicted physics, thermal, fission product, and materials behavior in the Peach Bottom reactor. These design methods verifications, to be completed in CY-78, utilize the data determined during three consecutive phases of the program, together with the data determined in a complementary program of Peach Bottom driver fuel element postirradiation examinations at ORNL. The three phases are (1) nondestructive fuel and circuit gamma scanning at the Peach Bottom site, (2) removal of Peach Bottom steam generator and primary circuit components, and (3) laboratory examinations of removed components.

This report covers the gamma spectroscopic examinations of Peach Bottom reactor core components sponsored by General Atomic and by ERDA and EPRI under the Peach Bottom End-of-Life Program. Associated analyses and design methods verifications are also included. 
0

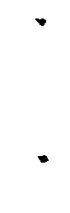


ABSTRACT

During discharge of Core 2 from the Peach Bottom High-Temperature GasCooled Reactor (HTGR), 55 driver elements, 21 test elements, three reflector elements, and one control rod with sleeve were axially gamma scanned with a high-resolution $\mathrm{Ge}(\mathrm{Li})$ detector. The purpose of the exercise was to determine fission product distributions for use in burnup calculations, power profile determinations, and fission product release and redistribution studies. The results showed that the predicted and measured burnups had a $\pm 7 \%$ root mean square deviation on an element-to-element basis and were within $\pm 0.7 \%(1 \sigma)$ on a core average basis. The element-to-element variation of $\pm 7 \%$ is within the generally stated $\pm 3 \%$ to $8 \%$ accuracy for nuclear predictions.

The only isotopes detected that redistributed within the elements were Cs-137 and Cs-134. This redistribution was characterized by release in the high-temperature upper portion of some driver elements, movement down the purge stream, and buildup on both sleeve and compact surfaces in the cooler portions of the element; the core average Cs-137 loss via migration through the sleeve into the coolant was undetectable within the measurement uncertainty of $\pm 0.4 \%(1 \sigma)$. The scanning of the reflectors and control rods showed low Cs-137 and Cs-134 contamination and some pronounced cesium buildup for the control rod sleeve. Cesium redistribution was found to vary with core position; elements on the periphery of the core exhibited less redistribution than elements near the center owing to higher temperatures.

Measured $\mathrm{Pa}-233$ profiles were found to be slightly different in shape from predicted thorium absorption rates. Radial power factors and their time history were reasonably well modeled. This conclusion was reached from activity measurements for total fuel elements at various radial core locations: long-lived isotopes followed the predicted time-averaged power 
distributions, whereas short-lived isotopes were approaching the end-of-life power predictions. Both end-of-life and time-averaged distributions enveloped the isotopic distributions of short- to long-lived nuclides. Axial power profiles were compared with short- and long-lived isotopes. The Cs-137 profiles verified the calculated time-averaged power profiles, and $\mathrm{Zr}-95$ combined with La-140 adequately presented the predicted end-of-1ife axial power shape. Analysis of single-channel strip charts showed axial expansion of the driver fuel stacks as predicted and accounted for by the fuel element design. 
CONTENTS

FOREWORD . . . . . . . . . . . . . . . . . . . . . . . . . . . .

ABSTRACT . . . . . . . . . . . . . . . . . . . . . . . v v

1. INTRODUCTION . . . . . . . . . . . . . . . . . . . . . . . . .

2. EXPERIMENTAL DESCRIPTION . . . . . . . . . . . . . . . . . . . $2-1$

2.1. Equipment .. . . . . . . . . . . . . . . $2-1$

2.2. Scanning Procedure................. . 2-2

2.2.1. Axial Scans . . . . . . . . . . . . . . 2-2

2.2.2. Static Counts ............... 2-3

2.3. Data Processing .. . . . . . . . . . . . . . 2-3

2.3.1. Isotope CPM Table . . . . . . . . . . . . 2-4

2.3.2. Isotope Ratio Table .. . . . . . . . . 2-5

2.3.3. Normalized Isotope Ratio Table . . . . . . . 2-6

2.3.4. Absolute Isotope Concentrations . . . . . . . 2-6

2.3.5. Interpolation Table .. . . . . . . . . . 2-7

2.3.6. Statistical Test Table... . . . . . . . 2-7

2.3.7. Plot Package .. . . . . . . . . . . 2-8

2.4. Calibrations . . . . . . . . . . . . . . . . 2-8

3. RESULTS . . . . . . . . . . . . . . . . . . 3-1

3.1. Fuel Stack Lengths . . . . . . . . . . . . . . . . . 3-1

3.2. Power Profiles . . . . . . . . . . . . . . . 3-4

3.2.1. Axial Profiles................ 3-5

3.2.2. Radial Profiles . . . . . . . . . . . 3-5

3.3. Composite Burnup . . . . . . . . . . . . . . . 3-7

3.4. Fission Product Release and Redistribution....... . 3-11

3.5. Thorium Absorption Rates... . . . . . . . . . . 3-18

4. CONCLUSIONS . . . . . . . . . . . . . . . . . . . 4-1

5. ACKNOWLEDGMENTS . . . . . . . . . . . . . . . . . 5-1

6. REFERENCES . . . . . . . . . . . . . . . . . . . . 6-1 
APPENDIX A FIGURES . . . . . . . . . . . . . . . . . . A-1

APPENDIX B TABLES . . . . . . . . . . . . . . . . . . . . . B B-1

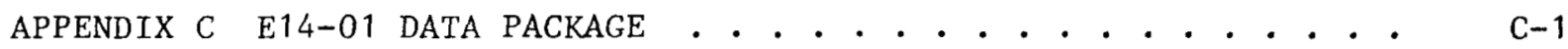

FIGURES

1. Peach Bottom elements scanned during Phase I . . . . . . A-3

2. Peach Bottom elements scanned during Phase II . . . . . . A A-4

3. Collimator geometry in Peach Bottom charge machine . . . . . A-5

4. Test arrangement for gamma scanning Peach Bottom test

5. Electrical schematic of Peach Bottom gamma scanning

equipment . . . . . . . . . . . . . . . . . . A-7

6. Effective scanning paths of Peach Bottom EOL gamma

7. Detector counting efficiency for Phase I and Phase II gamma scanning. . . . . . . . . . . . . . . . . A A

8. E14-01 strip chart recording of $\mathrm{Cs}-137$.......... . A-11

9. Measured axial strain versus fast fluence at various

10. Fitted axial strain versus fast fluence at various temperatures . . . . . . . . . . . . . . . A A-14

11. Normalized nuclide CPM ratio axial profiles of $\mathrm{Zr}-95$ and La-140 for E14-01 . . . . . . . . . . . . . A-15

12. Normalized nuclide CPM ratio axial profiles of $\mathrm{Zr}-95$

13. FEVER time-averaged power profile comparison for E14-01 . . A-17

14. FEVER calculated EOL power profile comparison for E14-01 . . A-18

15. EOL axial power profile comparison for 14 Phase I unperturbed elements . . . . . . . . . . . . . A A-19

16. Normalized radial distribution of $\mathrm{La}-140$ and $\mathrm{Zr}-95$ in Phase I driver elements . . . . . . . . . . A A-20

17. Normalized radial distribution of $\mathrm{Zr}-95$ in Phase II driver elements . . . . . . . . . . . . . . . . A-21

18. Normalized radial distribution of $\mathrm{Cs}-137$ in Phase I driver elements . . . . . . . . . . . . . A $\mathrm{A}-22$

19. Normalized radial distribution of Cs-137 in Phase II driver elements . . . . . . . . . . . . A-23 
20. Normalized radial isotope distribution summary for

Phase I. . . . . . . . . . . . . . . . . . $\mathrm{A}-24$

21. Cs-137 inventory versus axial core position for F03-01 . . A-25

22. FISS-PROD calculated Cs-137 inventories for Peach Bottom driver elements . . . . . . . . . . . . . . ${ }^{A}-26$

23. Absolute cesium nuclide activities for (a) E01-01,

(b) E03-02, (c) E06-02, (d) E09-01, (e) E11-01, and

(f) E14-01.....................

24. Absolute cesium nuclide activities for (a) F02-01,

(b) F04-03, and (c) F15-14. Solid curves are FISS-PROD

calculations... . . . . . . . . . . . . $\mathrm{A}-28$

25. Relative $\mathrm{Cs}-137$ difference versus core location . . . . A-29

26. Relative $\mathrm{Cs}-137$ difference versus mean element temperature .................. . A-30

27. Ce-141/2r-95 CPM ratio versus thermal fluence . . . . . . A-31

28. Ru-103/Zr-95 CPM ratio versus thermal fluence . . . . . . A-32

29. I-131/2r-95 CPM ratio versus thermal fluence. . . . . . A-33

30 (a). Cerium/zirconium nuclide CPM ratios for E01-01. . . . . . A-34

30 (b). Absolute cerium nuclide activities for E01-01 . . . . . . A-34

31(a). Ruthenium/zirconium nuclide CPM ratios for E01-01 . . . . A-35

31 (b). Absolute ruthenium nuclide activities for E01-01... . . A-35

32 (a). Iodine/zirconium nuclide CPM ratios for E01-01..... . A-36

32(b). Absolute iodine nuclide activities for E01-01 . . . . . A-36

33. Normalized protactinium CPM ratios for E14-01 . . . . . . A-37

34. Normalized radial distribution of $\mathrm{Pa}-233$ in Phase I driver elements . . . . . . . . . . . . . A-38

35. Normalized radial distribution of $\mathrm{Pa}-233$ in Phase II driver elements . . . . . . . . . . . . . A A-39

\section{TABLES}

1. Peach Bottom elements gamma scanned during Phase I. . . . B-3

2. Peach Bottom elements gamma scanned during Phase II . . . . B-4

3. Nuclear constants for isotopes used in Peach Bottom EOL gamma scanning... . . . . . . . . . . . B-5

4. FTE-6 comparison of fuel stack length . . . . . . . . B-6

5. FTE-18 comparison of fuel body and stack lengths derived from metrology and gamma scanning .. . . . . . . . $\mathrm{B}-7$ 
6. Phase I and Phase II fuel stack length comparison for driver elements . . . . . . . . . . . . . . B-8

7. Comparison of stack length of test elements . . . . . . . B-9

8. Burnup comparison for driver and test elements scanned during Phase I of Peach Bottom EOL program . . . . . . . B-10

9. Burnup comparison of driver elements scanned during Phase II of Peach Bottom EOL program . . . . . . . . . . B-11

10. Cs-137 inventory comparison of Phase I driver elements . . . B-12

11. Cs-137 inventory comparison of Phase I and II driver elements................. . . B-13

12. F03-01 Cs-137 inventory comparison . . . . . . . . . . B-14

13. E01-1 comparison of calculated and measured axial Cs-137 inventory . . . . . . . . . . . . . B $\mathrm{B} 15$

14. E03-02 comparison of calculated and measured Cs-137 inventory . . . . . . . . . . . . . . B-16

15. E06-02 comparison of $\mathrm{Cs}-137$ axial inventory . . . . . . B-17

16. E09-01 comparison of measured and calculated $\mathrm{Cs}-137$ axial inventory ................. B-18

17. E11-01 comparison of $\mathrm{Cs}-137$ axial inventory . . . . . . . B-19

18. E14-01 comparison of measured and calculated Cs-137 axial inventory . . . . . . . . . . . . . . . B-20

19. Survey temperature predictions for Peach Bottom driver elements . . . . . . . . . . . . . . . . B-21

20. Position and magnitude of maximum $\mathrm{Cs}-137$ release in driver elements .. . . . . . . . . . . . . B-22

21. Position and magnitude of maximum $\mathrm{Cs}-137$ plateout in driver elements ................. 


\section{INTRODUCTION}

The final shutdown of the Peach Bottom HTGR on October 31, 1974, presented a unique opportunity to measure the isotopic distribution of gamma ray emitting radionuclides in about $10 \%$ of the fuel elements. Fifty-five fuel driver elements, 21 fuel test elements, three reflector elements, and a control rod and sleeve were axially gamma scanned. A description of the core components is given in Ref 1 . The first scanning operation took place from November 24 to December 18, 1974, to measure short-half-lived isotopes; the second phase was between May 28 and June 8, 1975, to detect long-lived isotopes. The elements in Phase I and II scanning operations are listed in Tables 1 and 2, respectively, and are shown in core maps in Figs. 1 and $2 . *$ Phase I was privately funded by General Atomic (GA), and the program was merged with the EPRI/ERDA-sponsored Peach Bottom End-of-Life Program for the Phase II measurements.

The raw spectra of all the gamma scanning were stored on GA SIGMA II tapes (see Table 1). Analysis of these spectra was performed using a spectra integration program (PBGST) and a special data reduction program (PBEOLGS), which are discussed in Section 2.3. The objectives as outlined in the gamma scanning test plan (Ref. 2) are to determine:

1. Axial and radial power distributions.

2. Relative and absolute burnup.

3. Fission product distributions.

\footnotetext{
*Figures and tables appear in Appendixes $A$ and $B$, respectively.
} 
4. Axial and radial thorium absorption rate distributions near end of life (EOL).

5. Fuel column length changes during irradiation.

The feasibility of gamma spectroscopic examination of HTGR fuel elements had been demonstrated by the Dragon Project (Ref. 3). The methodology for the evaluation of the Peach Bottom EOL gamma scan examination was developed with the analysis of FTE-6 (Ref. 4).

Ten different isotopes, which are listed in Table 3 together with their nuclear constants, were chosen to establish the following types of information:

\section{Isotope $\quad$ Application}

Cs-137 (absolute inventory) Composite FIMA and Cs-137 loss

$\begin{array}{ll}\begin{array}{l}\text { La-140 (relative) } \\ \text { Zr-95 (relative) }\end{array} & \begin{array}{l}\text { Normalized power distribution for 1ast } 50 \text { to } \\ 200 \text { days* of reactor operation }\end{array} \\ \text { Cs-137 (relative) } & \begin{array}{l}\text { Normalized time-averaged power distribution** } \\ \text { Cs-134/Cs-137 (relative) }\end{array} \\ & \begin{array}{l}\text { Normalized time-averaged thermal fluence } \\ \text { distribution** }\end{array}\end{array}$

Pa-233 (relative) Normalized Th-232 absorption rates

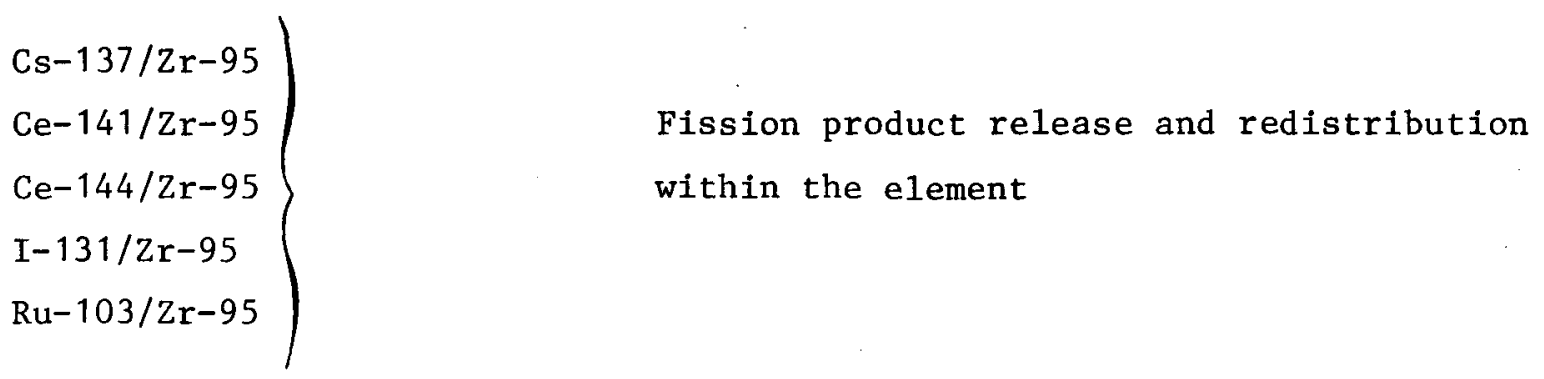

*Three half-lives assumed.

**Assuming fuel loadings and no cesium migration. 


$$
\text { Strip charts of single-channel scans were analyzed to determine the }
$$

change in fuel stack lengths during irradiation by comparison with preirradiation data. 


\section{EXPERIMENTAL DESCRIPTION}

\subsection{EQUIPMENT}

The general arrangement of the gamma scanning equipment at Peach Bottom is outlined in Figs. 3 through 5. The major components were a collimator, a charge machine, a Ge(Li) gamma spectrometer, and associated electronic data acquisition equipment.

The Peach Bottom charge machine was outfitted with a gamma scan port that penetrated nearly through its wall; a $12.7-\mathrm{mm}$ steel plate separated the end of the collimator from the charge machine cavity (see Figs. 3 and 4 and Ref. 2). With an element positioned in the charge machine cavity, the collimator system allowed the measurement of gamma ray emissions from a fixed volume of fuel. The collimator geometry and the scanning paths of the two collimators that were used on the majority of the scans are shown in Fig. 6 .

The charge machine driver mechanism was modified to slow movement of the element past the collimator slit (Fig. 4). Attached to the driver mechanism shaft were a meter and a single-turn potentiometer, which were calibrated (Ref, 8) and used to visually and electronically monitor the position of the element relative to the collimator system. Additionally, a switch was installed on the driver mechanism shaft and was activated once during each revolution of the shaft. When the switch was activated, a pulse signal was sent for graphical recording, which provided a log of element position as a function of time.

The gamma rays passing through the collimator slit were monitored using a high-resolution $\mathrm{Ge}(\mathrm{Li})$ detector. The detector was isolated in a lead case to reduce background activity to a minimum. The signal from the detector 
was transmitted to two monitoring systems: (1) a pulse height multichannel analyzer (MCA) and (2) a series of single-channel analyzers (SCAs) (Fig. 5). The MCA-accumulated gamma ray spectra were stored on magnetic tape for computer analysis and data processing at GA. The SCA activity data of selected nuclide peaks and their backgrounds were graphically recorded continuously as a function of time on $X-Y$ plotters and at 1-min intervals with scalers and a teletype unit.

\subsection{SCANNING PROCEDURE}

Two types of measurements were performed on each element: (1) measuring activities while the element was slowly moved past the collimator system (axial scans) and (2) measuring activities at a specified location with the element stationary (static scans). The sequence of each element scan was as follows:

1. Calibration (Cs-137, Co-60 source).

2. Background measurements.

3. Axial scans.

4. Static scans on selected fuel locations.

5. Trap scan.

6. Second calibration (Cs-137, Co-60 source).

\subsubsection{Axial Scans}

For the axial scans, the element was moved at a constant speed $(\sim 70 \mathrm{~mm} /$ min) past the collimator system with all gamma ray monitoring systems operating, i.e., (1) MCA-magnetic tape, (2) SCA-ratemeter-recorder, and (3) SCAscaler-teletype. The axial scans were generally started $0.6 \mathrm{~m}$ and $0.3 \mathrm{~m}$ below the start of the fuel column for Phases I and II, respectively, and ended above the top of the fuel column in both Phase I and II scanning. The MCA was operated in a LIVE-TIME mode with a 50-s count time. During the magnetic tape recording operation, no spectrum was being accumulated in the analyzer ( $4.3-s$ dead-time). The SCA-ratemeter output was continuously 
graphically recorded along with the pulse signals from the drive mechanism locations and magnetic tape and teletype record pulses. The scalar count times were $60 \mathrm{~s}$ with a dead-time of $\sim 6 \mathrm{~s}$ during the teletype record time.

\subsubsection{Static Counts}

Measurements were made with the elements stationary using both the MCA and SCA scalar systems. The MCA was operated in a LIVE-TIME mode with a count time of $5 \mathrm{~min}$; simultaneously, five 60 -s counts were made at each scan location on the element with the SCA scalar systems.

Static counts were made in the top, middle, and bottom sections of the driver fuel column (usually at the center of compacts 5, 16, and 25), in the trap area of the element, and in the graphite portion of the element for background. For test elements, static counts were made at the center of each fuel body and in the trap area. Additional static counts were made on fuel elements selected for destructive postirradiation examination (PIE) or at locations where unusual activity was noted from the SCA graphs.

\subsection{DATA PROCESSING}

On an average, 50 to 60 spectra were measured for each element and recorded on magnetic tape.

The raw spectra collected at Peach Bottom were transcribed and analyzed using the SIGMA II computer PBGST program at GA (Ref. 7). This program identified the isotope peaks, integrated the area under each peak, subtracted out the background, and calculated the $2 \sigma$ counting error (Ref. 9). In addition, the program decayed the counts-per-minute (CPM) back to EOL of Core 2 (October 31, 1974, 15.35 hr) and corrected the counts for the relative detector efficiency, absolute intensity, attenuation of the 12.7-mm steel plate, and approximate attenuation of the fuel bodies. These corrections (see Table 3) gave a modified CPM value which is approximately proportional to the disintegration rate of the various isotopes. These corrections were 
not used in the following analysis because of an absolute calibration technique described in Section 2.4; however, comparison with absolute values showed the relative corrections to be within measurement errors (Ref. 7).

The processed SIGMA II tape was then translated to the UNIVAC-1110 (Ref. 10) for data analysis. Tabulation of element scans, calculations of absolute CPM and composite FIMA values, and comparisons and plots of isotope profiles were all done using the PBEOLGS program (Ref. 11). The entire PBEOLGS data package for element E14-01 is presented in Appendix $C$ as an example. The tables and calculations are described in Sections 2.3.1 through 2.3.7.

\subsubsection{Isotope CPM Table}

The first table (see Appendix C) lists the CPM of the ten selected isotopes and their associated $1 \sigma$ counting errors, core position, identity, and scan interval. The scans are listed in chronological order except for the static counts, calibrations, and miscellaneous scans that are tabulated separately. In the driver elements, the automatic scans were also separated into three strata, which represent the bottom graphite section, fuel section, and upper graphite section; the static scans were listed as one stratum in each element scan. In the test elements, the scans were stratified on a body-to-body basis. The strata information was then included in the weighted mean and associated statistical information, which is explained by the following algorithms:

$$
\begin{aligned}
& \text { WT MEAN CPM }=\sum \mathrm{w}_{i} \mathrm{CPM}_{i}=\overline{\mathrm{CPM}}, \\
& \mathrm{w}_{i}=\frac{\ell_{i}}{\Sigma l_{i}},
\end{aligned}
$$

where $W_{i}=$ weighting factor,

$$
\begin{aligned}
\ell_{i} & =\text { scan interval, } \\
\mathrm{CPM}_{i} & =\mathrm{CPM} \text { for each individual scan, }
\end{aligned}
$$


WT MEAN CPM = mean $C P M$ weighted with scan interval;

WT MEAN 1 SIGMA $=\left(\sum w_{i} s_{i}^{2}\right)^{1 / 2}$,

where

$S_{1}=$ standard error for each individual scan $(1 \sigma)$;

$$
\begin{aligned}
\text { WT RMS } & =\left[\sum \mathrm{W}_{i}\left(\mathrm{CPM}_{i}-\overline{\mathrm{CPM}}\right)^{2}\right] 1 / 2 ; \\
\text { WT ERROR } & =\left[\sum \mathrm{w}_{i}^{2}(\mathrm{~S})_{i}^{2}\right] 1 / 2 .
\end{aligned}
$$

\subsubsection{Isotope Ratio Table}

The isotope ratio gives the calculated CPM ratios of various isotopes for each scan from the CPM table (Section 2.3.1). The following statistical algorithms apply:

$$
\text { RATIO }=R_{i}=\frac{C P M_{A}}{C P M_{B}} \text {, }
$$

1 SIGMA ERROR $=R_{i}\left[\left(\frac{S_{A}}{C_{A}}\right)^{2}+\left(\frac{S_{B}}{C_{A} M_{B}}\right)^{2}\right]^{1 / 2}=S_{R i}$,

WT MEAN RATIO $=\sum W_{i} R_{i}=\overline{R_{i}}$,

WT MEAN 1 SIGMA $=\left(\sum w_{i} s_{\mathrm{Ri}}^{2}\right)^{1 / 2}$,

$$
\begin{aligned}
\text { WT RMS } & =\left[\sum W_{i}\left(R_{i}-\overline{R_{i}}\right)^{2}\right]^{1 / 2}, \\
\text { WT ERROR } & =\left(\sum W_{i}^{2} R_{i}^{2}\right)^{1 / 2} .
\end{aligned}
$$




\subsubsection{Normalized Isotope Ratio Table}

The normalized isotope ratio table shows the CPM of various isotopes normalized to the total weighted mean of all strata containing fuel. The following algorithms apply (Ref. 4):

$$
\mathrm{N}_{i}=\frac{\mathrm{CPM}_{1}}{\overline{\mathrm{CPM}}}
$$

where $\quad N_{i}=$ normalized ratio,

$\mathrm{CPM}_{\mathbf{i}}=\mathrm{CPM}$ for each scan (see Section 2.3.1),

$\overline{\mathrm{CPM}}=$ weighted mean of all fuel sections (total strata mean);

1 SIGMA ERROR $=\frac{\mathrm{CPM}_{i}}{\overline{\mathrm{CPM}}}\left[\left(\frac{{ }_{\mathrm{CPM}_{i}}}{\mathrm{CPM}_{i}}\right)^{2}\left(1-\frac{2}{\mathrm{~N}} \frac{\mathrm{CPM}_{i}}{\overline{\mathrm{CPM}}}\right)+\left(\frac{\mathrm{S}_{\overline{\mathrm{CPM}}}}{\overline{\mathrm{CPM}}}\right)^{2}\right]^{1 / 2}$,

where $\mathrm{S}_{\mathrm{CPM}_{i}}=1$ SIGMA counting error of isotope 1 on each scan,

$\mathrm{S}_{\overline{C P M}}=1$ SIGMA counting error on mean CPM along the fuel element (of any preselected strata) (see Eq. 5).

The WT MEAN, RATIO, WT MEAN 1 SIGMA, WT RMS, and WT ERROR are all calculated from Eqs. 6 through 11 in Section 2.3.2.

\subsubsection{Absolute Isotope Concentrations}

The quantitative isotope concentrations and composite fissions per initial metal atom (FIMA) using $\mathrm{Cs}-137$ and $\mathrm{Ru}-106$ are shown in the next table (see Appendix $C$ ). The calculations of the curies and FIMA are explained in section 3.3. For convenience, the reported curie value at each axial location is for an equivalent compact at that position (see Section 
2.4 for a detailed discussion of calibration). This allows the direct comparison of results using different collimators and gamma scanning of fuel compacts at ORNL without the need for complicated scanning geometry corrections. The error analysis of these calculations is discussed in detail in Ref. 4. Reduction of the strata information is done with the algorithms outlined in Section 2.3.1.

\subsubsection{Interpolation Table}

The interpolation linearly interpolates the CPM and ratios to any set of axial locations. The centerlines of all compacts are used for interpolation points for the: fuel driver elements. Because the scan interval is equal by definition, the algorithm can be simplified:

$$
\begin{aligned}
\overline{\mathrm{X}} & =\frac{1}{\mathrm{n}} \sum \mathrm{x}_{i}, \\
\mathrm{~S}_{\overline{\mathrm{x}}} & =\left(\frac{1}{\mathrm{n}} \sum \mathrm{S}_{\mathrm{x}}^{2}\right)^{1 / 2}, \\
\operatorname{RMS} & =\left[\frac{1}{\mathrm{n}} \sum\left(\mathrm{R}_{\mathrm{i}}-\overline{\mathrm{R}}\right)^{2}\right]^{1 / 2}, \\
\text { ERROR } & =\left(\frac{1}{\mathrm{n}^{2}} \sum \mathrm{s}_{\mathrm{x}}{ }^{2}\right)^{1 / 2} .
\end{aligned}
$$

\subsubsection{Statistica1 Test Table}

The statistical test table is designed to compare any stratified measured information with predictions or equivalent measured information for statistical significance. The relative difference between the two values for comparison calculated with an associated error and a statistical individual agreement test is applied to the comparison. These tests and the method of calculation are outlined in Section 3.1 . 


\subsubsection{Plot Package}

Any strata information can be plotted against the axial core location of the particular scan along the fuel element.

\subsection{CALIBRATIONS}

To calculate absolute curie and FIMA values for the driver elements it was necessary to calibrate the scanning geometry at Peach Bottom. This was achieved for Phase I by cross-calibrating the results determined from ORNL on individual driver element compacts from element E14-01 (Ref. 12) and the in situ scanning of E14-01 at the Peach Bottom site. E14-01 was chosen as a calibration element because it did not show significant cesium transport (Ref. 12). If an element with cesium transport had been used for calibration, it would have been impossible in the Peach Bottom scans to separate the detected cesium activity in the compact from that built up on the graphite components. This would have caused an erroneous comparison with individual compact activities determined at ORNL, which do not contain the accumulated cesium activity of the sleeve and center spine cross sections seen in the Peach Bottom scans (see Fig. 6). However, this problem can be overcome by composition of activity measurements at ORNL for compact and graphite components, as described in section 3.4 .

In the calibration procedure, four static scans were taken from E14-01 which corresponded to the mean activities of the four compacts measured at ORNL. Using the absolute isotope activities measured at ORNL for each compact and the relative activity in CPM observed at Peach Bottom, the absolute counting efficiency of the Phase I Peach Bottom gamma scanning geometry (17.47-mm $\times 0.254-\mathrm{mm}$ collimator) can be determined using the following equation for each particular nuclide gamma energy peak:

$$
\mathrm{CE}=\frac{\mathrm{CPM}}{\mathrm{DPM} * \mathrm{~A} \cdot \mathrm{I} .} \text {, }
$$


where $C E=$ absolute counting efficiency,

CPM = counts per minute measured at Peach Bottom for about $76.2 \mathrm{~mm}$ ( 3 in.) of axial fuel element length,

DPM = disintegrations per minute measured at ORNL for a single fuel compact of 76.2-mm (3-in.) length,

A.I. = absolute intensity of a particular isotope.

This expression includes all the geometry and attenuation effects associated with the Peach Bottom scans. All driver fuel spectra were converted to an equivalent axial fuel element section of $76.2 \mathrm{~mm}$ ( $3 \mathrm{in}$.) at the axial midpoint of each scan. This calibration does not fully account for relative depletion or enrichment of a mobile isotope along the scanning geometry due to radial and axial migration compared with nonmobile isotopes within the scanned volume. For the releasing element F03-01, the measured Cs-137 inventory was close to that predicted (see Section 3.4), which indicates that the geometry effects described above still allowed the determination of axial Cs-137 and Cs-134 activity within the accuracy of the calibration.

The counting efficiency was calculated for all the isotope energy peaks except La-140 and I-131, which were too short-lived to be detected at ORNL. The counting efficiency of these two isotopes and all other isotopes was determined from the logarithmic first-order fit through the counting efficiency versus energy data of peaks greater than $300 \mathrm{keV}$ (Fig. 7).

Because the counting efficiency changes with each geometry, it was also necessary to determine the counting efficiency for the gamma scanning of Phase II driver elements, which were measured with a $6.35-\mathrm{mm} \times 1.27-\mathrm{mm}$ collimator. All of the driver elements scanned at ORNL were from Phase I; therefore, the calibration procedure used for Phase I was not applicable for Phase II gamma scanning. To correct for this, several collimators used 
on E14-02 and E03-01 were intercompared to determine a factor that could be multiplied by the Phase I counting efficiencies to give appropriate results for the Phase I scans. Element E14-02 was scanned with the 0.254-mm $\mathrm{x} 17.475-\mathrm{mm}$ and $0.254-\mathrm{mm} \times 23.876-\mathrm{mm}$ collimators, and E03-01 was scanned with the $0.254-\mathrm{mm} \times 23.876-\mathrm{mm}$ and $1.270-\mathrm{mm} \times 0.635-\mathrm{mm}$ collimators. The relationship between the various CPM values seen by each collimator is as follows:

$$
\frac{B}{A} * \frac{C}{B}=\frac{C}{A}=5.025,
$$

where $A=(0.254 \mathrm{~mm} \times 17.475 \mathrm{~mm})$ Phase I driver elements,

$B=(0.254 \mathrm{~mm} \times 23.876 \mathrm{~mm})$ Phase I and II driver elements,

$\mathrm{C}=(1.270 \mathrm{~mm} \times 0.635 \mathrm{~mm})$ Phase II driver elements.

The counting efficiency of each isotope used in the analysis of Phase II was determined by multiplying the counting efficiency determined for the Phase I collimator by 5.025. Both calibration curves are shown in Fig. 7 . Certain elements in both Phase I and Phase II could not be calibrated for quantitative results. The nonfueled components including reflectors (A18-08, D18-12, and D17-12), a guide sleeve (E08-01G), and a control rod (E08-01) had no calibration. In Phase I, FPTE-3 (E14-08) and FTE-18 (E06-01) (Ref. 9) were not calibrated because of unusual fueled geometries and can presently only be evaluated in relative terms. Some isotope calibration data may become available from PIEs at the Atomic Energy Research Establishment (AERE), Harwell, Great Britain, and Kernforschungsanlage (KFA), Jülich, West Germany. In Phase II, F01-01, F07-06, F09-08, F10-09, F14-13, and F12-11 did not yield quantitative results because of collimator or detector problems during scanning, * which were not recognized until the fuel elements were sealed for final disposal in Idaho.

Several of the driver elements were scanned twice for reproducibility: Specifically, the double scanning of A17-11 and C02-01 (FTE-6) showed

\footnotetext{
*F01-01 lost collimator identity; F07-06, F09-08, F10-09, and F12-11 had collimator or detector problems; and F14-13 was inadvertently scanned with a lead shield in place.
} 
measurements of all the isotopes to be well within the $2 \sigma$ counting errors as shown below:

\begin{tabular}{c|c|c}
\hline \multirow{2}{*}{ Element } & \multicolumn{2}{|c}{ Pa-233 Activity } \\
\cline { 2 - 3 } & $\begin{array}{c}\text { Scan } 1 \\
(\mathrm{CPM} \pm 2 \sigma)\end{array}$ & $\begin{array}{c}\text { Scan } 2 \\
(\mathrm{CPM} \pm 2 \sigma)\end{array}$ \\
\hline $\begin{array}{c}\text { A17-11 } \\
\text { C02-01 (FTE-6) }\end{array}$ & $49,224 \pm 902$ & $49,441 \pm 900$ \\
Body 1 & $168 \pm 12$ & $171 \pm 13$ \\
Body 2 & $341 \pm 25$ & $302 \pm 23$ \\
Body 3 & $349 \pm 30$ & $341 \pm 28$ \\
\hline
\end{tabular}

The counting efficiency of the test element gamma scans was calculated using the same methodology applied to the driver elements. The source terms in both the six- and eight-hole teledial configurations came from FTE-15 (Ref. 13) and FTE-6 (Ref. 4) hot cell gamma scanning at GA. By calculating the volume percent of each fuel rod scanned in the collimator path (see Fig. 6), the total absolute activity of each of the major isotopes was determined from calibrated $G A$ hot cell scans on individual fuel rods. Using these calibrated disintegrations per minute (DPM) values and the CPM values seen in the Peach Bottom scanning of FTE-6 and FTE-15, the counting efficiency was calculated using Eq. 18. The absolute curie values quoted in the analysis section for the fuel test elements are for the volume of fuel and graphite seen by the collimator in Fig. 6 over the nominal length of a standard equivalent fuel rod $(49.28 \mathrm{~mm}$ or $63.5 \mathrm{~mm}$ for the eight- or six-hole teledial configuration, respectively) which has its midpoint at the centerline of each Peach Bottom scan. The difference between the driver and test element calibration is the corresponding fuel and graphite volume, which is the equivalent of one fuel compact inclusive spine and sleeve section, whereas test element inventories are representative for the fraction of fuel rods (about 3 and 3.5 fuel rods for six- and eight-hole teledial configurations, respectively) and graphite within the collimator path shown in Fig. 6 . 


\section{RESULTS}

\subsection{FUEL STACK LENGTHS}

One of the goals of the Peach Bottom EOL gamma scanning program was to determine the in situ fuel stack lengths of various driver and test elements from Phase I and Phase II. Using the single-channel strip charts of various nuclides and the calibrated Veeder-Root location system, the fuel stack lengths were determined for each fuel element scanned. Figure 8 shows a typical strip chart from driver element E14-01. In most cases, several nuclide strip charts were available for each fuel element; therefore, the mean, $\bar{x}$, and standard deviation on the mean, $S_{\bar{x}}$, were calculated when applicable.

The statistical tests used for the comparison of the methods were the individual values agreement test, the group agreement test, and the group goodness-of-fit test (Ref. 4). The null hypothesis, i.e., that there is no difference, is accepted at the 0.05 significance level for the individual value agreement test if

$$
|d j|=\left|\frac{Z_{j}}{S_{Z j}}\right| \leq 1.96,
$$

$$
\text { where } \begin{aligned}
\mathrm{Z}_{j} & =\text { relative difference, } \\
\mathrm{S}_{\mathrm{Z}_{j}} & =\text { error on the relative difference. }
\end{aligned}
$$

The group agreement test is passed if

$$
|\sqrt{\mathrm{m}} \overline{\mathrm{d}}| \leq 1.96
$$

where $\mathrm{m}=$ number of measured values or tests,

$$
\bar{d}=\text { average of } z_{j} /\left|s_{z j}\right| \text { for the } m \text { values. }
$$


The group goodness-of-fit test is accepted if

$$
\frac{1}{m} \sum\left(\frac{s_{j}}{s_{Z j}}\right)^{2} \leq \frac{x_{0.95}^{2}}{m}
$$

where $x_{0.95}^{2}=$ upper 95 percentile point for the chi-squared distribution with $m$ degrees of freedom.

The axial variability is within the uncertainty of the measurements if

$$
\frac{\mathrm{mRMS}}{\mathrm{df} \sigma^{2}} \leq \frac{\chi_{0.95}^{2}}{\mathrm{df}}
$$

where $\begin{aligned} \mathrm{df}= & \text { degree of freedom (usually } \mathrm{m}-1 \text { ), } \\ \sigma^{2}= & 1 / \mathrm{m} \sum_{\mathrm{RMS}^{2}=} \mathrm{S}_{Z_{j}}^{2} \text { mean measurement error, } \\ & \text { variability). }\end{aligned}$

Comparison of fuel body stack lengths from the destructive PIEs and the Peach Bottom EOL gamma scanning of FTE-6 (Ref. 4) was used to qualify the accuracy of the gamma scanning method. As shown in Table 4, there are no significant differences in the two measurements. This permits the confident use of stack lengths for elements where no direct postirradiation measurements are available.

For the Phase I element, FTE-18 (Ref. 9), single-channel isotope plots were analyzed for fuel body and total stack lengths. A comparison of the lengths as derived from metrology and gamma scanning is shown in Table 5. The following conclusions can be drawn:

1. When comparing total fuel body stack length information determined from gamma scanning and metrology, a bias of $\hat{b}=8 \pm 2 \mathrm{~mm}$ was detected for the Peach Bottom scan length over all six fuel bodies. 
However, this is a small relative error of $0.4 \pm 0.1(1 \sigma) \%$ over a total length of $2083 \mathrm{~mm}$ (82.01 in.).

2. The associated error with the Peach Bottom scan-derived fuel body strain data can be as large as the measured effect. Therefore, for strain information, metrology data are preferred. On the average, the bias was $\hat{b}=54 \pm 17$ (10) (relative \%) between the two methods of strain measurements.

3. The hot cell scan data give an accurnulative EOL fuel length of $2051 \mathrm{~mm}$ ( $80.75 \mathrm{in.}$ ), which results in an accumulative fuel-free length of $32 \mathrm{~mm}(1.26 \mathrm{in.})$. This is a revision of the information presented in Ref. 9, which results from the recent calibration of the gamma scanner drive mechanism at the GA hot cell (change from $0.04 \mathrm{in.} / \mathrm{rev}$ to $0.04167 \mathrm{in.} / \mathrm{rev}$ ).

4. By application of the metrology-derived stack strain, the accumulative beginning-o $\dot{\mathrm{f}}-1$ ife (BOL) fuel length was $2063 \mathrm{~mm}(81.25 \mathrm{in.})$ rather than $2036 \mathrm{~mm}$ ( $80.16 \mathrm{in.)}$ nominal; i.e., the fuel-free zones at the ends of each fuel body averaged $2.7 \mathrm{~mm}(0.11 \mathrm{in}$.) rather than $5 \mathrm{~mm}$ (0.2 in.).

5. Significant differences between metrology-derived and Peach Bottom gamma-scan-derived length measurements were detected at the $95 \%$ confidence level by application of statistical test methods. However, the absolute differences are small and are acceptable for length determination. For reliable strain information, precision metrology is the preferred method.

Results of the relative change of in situ stack lengths for Phase $I$ and Phase II driver elements are presented in Table 6. Table 7 shows the results of the test elements scanned in Phase $I$. The driver element strains are compared with mean fast fluence and time-averaged fuel temperatures in 
Figs. 9 and 10. The following conclusions can be drawn from the results of the Phase I and Phase II gamma-scan-derived fuel stack lengths:

1. Fuel stack lengths of driver elements had an average expansion of $0.7 \%$ with a standard deviation on the mean of $\pm 0.2 \%$. The fuel stack expansion tended to increase with both fast fluence and temperature. The data were found to best follow the computerderived relationship (see Fig. 10)

$$
\mathrm{d} \ell / \ell=\frac{2.45 \times 10^{-4} \phi \mathrm{T}}{10^{25} \mathrm{~cm}^{-2}{ }^{\circ} \mathrm{C}}(\%),
$$

$$
\text { where } \begin{aligned}
\phi & =\text { fast fluence }\left(10^{25} \mathrm{n} / \mathrm{cm}^{2}\right), \\
\mathrm{T} & =\text { element and time-averaged temperature }\left({ }^{\circ} \mathrm{C}\right), \\
\mathrm{d} l / \ell & =\text { strain of fuel stack length }(\%) .
\end{aligned}
$$

2. Fuel stack lengths in the test elements all decreased. All elements containing TRISO-BISO or TRISO-TRISO* fuel with the exception of FTE-9 showed approximately $1 \%$ shrinkage. Element FTE-9 showed shrinkage of $3.5 \%$ for a TRISO-BISO fuel, which is significantly more than expected and is believed to be a measurement error. Element FBTE-1 with BISO-BISO fuel shrank about $3 \%$, and blended beds in FBTE-5 had about $2 \%$ shrinkage.

\subsection{POWER PROFILES}

Short- and long-lived isotope profiles were used to verify, respectively, axial and radial EOL and time-averaged power profiles. Normalized profiles for $\mathrm{La}-140$ and $\mathrm{Zr}-95$ were used to test the power during the last 50 to 200 days, and Cs-137 and Cs-134/Cs-137 normalized profiles were used in the comparison of calculated time-averaged power profiles and thermal fluence profiles, respectively.

${ }^{*}$ Gamma spectroscopy only detects the fuel stack envelope, i.e., the stack with the least shrinkage; consequently, TRISO-TRISO fuel is usually detected. 


\subsubsection{Axial Profiles}

In the axial power profile comparison, two qualifications were necessary in the use of the isotope profiles. The first was that only elements with insignificant cesium migration could be used in the time-averaged power profile comparison. The other was that the loading of each element was assumed to be constant along its length; this assumption was necessary to allow the use of the $\mathrm{Cs}-134 / \mathrm{Cs}-137$ ratio, which is not related to the power if the fuel loading changes and is more representative of the thermal fluence distribution in any case.

In the Peach Bottom scans, $\mathrm{Zr}-95$ and La-140 profiles showed insignificant differences for unperturbed elements two or more locations away from control rods. This suggests little difference in the relative power profile for the last 50 to 200 days. Figure 11 shows the close agreement in these two isotope profiles for E14-01, which was not influenced by control rods. In driver elements that were near control rod banks which were gradually withdrawn toward EOL, the isotope profiles are different because of a significant change in the axial power profile distribution with time. Figure 12 shows an example of this for F03-01.

E14-01 was used in the comparison of FEVER-calculated isotope-derived power profiles. In Fig. 13 the E14-01 time-averaged profiles show good agreement between measurements and predictions except for the bottom of the core, where apparently more thermal neutron reflections occurred than was predicted. The E14-01 EOL power profiles are also compared with FEVERcalculated values in Fig. 14; in this case the profile flattened as predicted, but the shift in the peak to the top of the element was not obvious. When 14 unperturbed elements were grouped together, the average La-140 activity was found to follow the same trends as it did in E14-01 when compared with the FEVER EOL power (see Fig. 15).

\subsubsection{Radial Profiles}

Using the mean activity of La-140, $\mathrm{Zr}-95$, and $\mathrm{Cs}-137$ in driver elements not influenced by control rods, the radial core distribution of these 
isotopes was compared with the GAUGE-predicted EOL and time-averaged radial power profiles. Figures 16 and 17 show the predicted EOL profile and the normalized isotope activities of both La-140 and Zr-95 for Phase I from 15 unrodded fuel elements (as identified in Table $8^{*}$ ) and $\mathrm{Zr}-95$ for Phase II from 15 unrodded elements (see Table 9*). In both cases the normalized isotope profiles appeared somewhat flatter than the predicted EOL, with the Zr-95 profile being further away from the predicted EOL power shape than the La-140 profile.

The Cs-137 profile is also compared with the time-averaged power profile in Figs. 18 and 19 for Phase $I$ and Phase II, respectively. In both Phase I and Phase II driver elements, the relatively flat predicted timeaveraged power profile was substantiated by the measured Cs-137 activity.

In Fig. 20, a summary of the calculated radial power profiles and measured isotope profiles shows some interesting trends:

1. There appears to be an area around core radial position 9 or 10 with no change in the relative radial power production.

2. With increasing time, the relative power production became higher in the center and lower at the periphery, which makes the control rod removal pattern visible.

3. Owing to the fact that the predicted EOL and time-averaged power distributions envelope the short-, medium-, and long-life isotopic distributions on either side, it is concluded that the radial power factors and their time histories are reasonably well modeled.

*Except A03-03 for Phase I and E03-01, E14-02, and F05-04 for Phase II because of different irradiation exposure (A03-03) or arbitrary reduction toward the same sample size between Phase I and Phase II for statistical purposes. 


\subsection{COMPOSITE BURNUP}

Ru-106 and Cs-137 can be used to establish a composite burnup which is defined as the number of fissions occurring per initial heavy metal atom (FIMA).

The burnup can be calculated by

$$
\text { FIMA }_{c}=\frac{D P M}{\left(U_{0}+T_{o}\right) \lambda y} \text {, }
$$

where

$$
\begin{aligned}
& \text { FIMA }_{\mathrm{C}}=\text { composite burnup, } \\
& \mathrm{DPM}=\text { disintegrations/minute of isotope at EOL, } \\
& \lambda \quad=\text { isotope decay constant }\left(\min ^{-1}\right), \\
& y \quad=\text { fractional fission yield of isotope from U-235), } \\
& \mathrm{Th}_{\mathrm{O}} \quad \text { number of atoms of thorium at BOL, } \\
& \mathrm{U}_{\mathrm{O}} \quad \text { number of atoms of uranium at BOL. }
\end{aligned}
$$

A rigorous analysis requires the calculation of the decay of the isotope during the life of the reactor. When long-lived isotopes are used, the power fluctuations of the reactor become more insignificant and it can be assumed in most cases that the reactor operated at constant power for the life of the core. In this case the decay during life can be approximated by

$$
N^{\prime}=N\left(\frac{1-e^{-\lambda t}}{\lambda t}\right)
$$

$$
\text { where } \quad \begin{aligned}
& N^{\prime}=\text { atoms of isotope corrected for decay during life, } \\
& N=\text { atoms of isotope at EOL } \\
& \lambda=\text { isotope decay constant }\left(s^{-1}\right), \\
& t=\text { time of irradiation (s). }
\end{aligned}
$$

\footnotetext{
*Assume the same for U-233.
} 
There was gross redistribution of $\mathrm{Cs}-137$ in the majority of the elements, as discussed in Section 3.4. Substitution of Ru-106 as a fission monitor in cases of cesium loss or movement was not possible because of its low yield and consequently large counting error.

In cases where $\mathrm{Cs}-137$ was redistributed in the element but not lost, the total Cs-137 inventory can be used in the calculation of an element average FIMA and compared with GAUGE predictions. (GAUGE is a twodimensional depletion code in an $r-\Theta$ geometry.) It is felt to be a reasonable assumption in light of an approximate loss of $65 \mathrm{Ci}$ (Ref. 14) into the primary circuit, which is $2 \times 10^{-4}$ of the total Cs-137 inventory of the core.

Table 8 summarizes the FIMA comparison between all the driver elements and several test elements that had constant axial fuel loadings. In all cases the calculated and measured absolute FIMA were within $\pm 15 \%$ of each other.

To demonstrate the agreement of the calculated and measured FIMA on a core average basis, all the fuel driver elements except for F07-06, F09-08, F10-09, and F12-11, which showed scanning problems, and F01-01, which had no calibration, were averaged. The results are as follows:

FIMA $(\mathrm{n}=48)$

\begin{tabular}{c} 
Calculated \\
$($ at. \%) \\
\hline
\end{tabular}

Mean

7.53

$\pm 1.45$

RMS

Error $(1 \sigma)$

\begin{tabular}{l} 
Measured \\
(at. \%) \\
\hline
\end{tabular}

$$
7.59
$$$$
\pm 1.54
$$$$
\pm 0.05
$$

\section{Relative Difference}

$\underline{(C / M-1)=\bar{Z}} \quad \underline{S_{\bar{Z}}(1 \sigma)}$.

$\pm 0.007$

(a) Mean relative measurement error for individual driver elements. 
This analysis shows a $-0.4 \% \pm 0.7 \%(1 \sigma)$ higher FIMA than that predicted by GAUGE. Using an individual agreement test discussed in Section 3.1, 14 out of 48 of the driver elements showed differences between the calculations and the measurements that could not be attributed to the measurement error. On a group basis (Eq. 21), the agreement showed that there was no difference at the 0.05 significance level between the measured and calculated values. Consequently, there was no significant difference between the calculated and measured burnup on a core average within the uncertainty of $\pm 0.7 \%$. (The established bias of $-0.4 \%$ is well within the uncertainty of $\pm 0.7 \%$ and can therefore be ignored.) The root mean square deviations, RMS, for the calculated and measured FIMA values were within $\pm 5 \%$ of each other, which is evidence that the element-to-element variation was well predicted for the core. The measured RMS is higher than the predicted, which is partially due to a superposition of counting errors in addition to the true element-toelement variability.

As mentioned above, several of the fuel elements showed significant differences between the calculated and measured FIMA values. Using the element-to-element variation test (Eq. 20), the difference between the calculated and measured burnups on a core basis was found to be significant, with $\pm 6.8 \%$ versus a mean counting error of $\pm 4.8 \%$. The observed range was between $+14 \%$ and $-15 \%$, which covers the $2 \sigma$ range of the observed RMS deviation. From a statistical viewpoint, the deviations for all the 48 driver elements participating in the test were within the $2 \sigma$ range and therefore acceptable for the test.

In summary, it is concluded that the core average power was predicted within $\pm 0.7 \%(1 \sigma)$ and that the element-to-element variation between predicted and measured local power was within $\pm 6.8 \%(1 \sigma)$. This is even better than the commonly stated uncertainty of $\pm 3 \%$ to $\pm 8 \%$ for nuclear depletion calculations (Ref. 15). 
Several test elements with uniform axial fuel loadings are compared with GAUGE-calculated values in Table 8. The comparison of the eight test elements with a mean element FIMA is shown below:

\begin{tabular}{|c|c|c|c|c|}
\hline & \multicolumn{2}{|c|}{ FIMA $(n=8)$} & \multicolumn{2}{|c|}{ Relative Difference } \\
\hline & $\begin{array}{c}\text { Calculated } \\
(\text { at. } \%) \\
\end{array}$ & $\begin{array}{l}\text { Measured } \\
(\text { at. } \%)\end{array}$ & $(\mathrm{C} / \mathrm{M}-1)=\overline{\mathrm{Z}}$ & $S_{\bar{Z}}(1 \sigma)$ \\
\hline Mean & 7.82 & 9.10 & -0.125 & \pm 0.022 \\
\hline RMS & \pm 2.22 & \pm 3.05 & \pm 0.122 & -- \\
\hline Error $(1 \sigma)$ & - & \pm 0.22 & $\pm 0.062^{(a)}$ & -- \\
\hline
\end{tabular}

(a) Mean relative measurement error for individual fuel test elements

On an individual element basis, four of the eight test elements showed significant differences between the measured and calculated values. On a group level, the bias between the calculated and measured values could not be explained by measurement errors. A possible explanation for the bias is the complicated scanning geometry (see Fig. 6). Because the amount of fueled volume can change with azimuthal movement, the confidence in the scanning configuration of the fuel test elements is less than for driver fuel elements, where rotation and off-axis effects of the element within the fuel handling machine had less effect on the scanned geometry. The lowering of the fuel elements from the fuel handing machine into storage cans was occasionally monitored with a television system. Very slight rotation and pendulum effects were observed during these operations.

The alternative explanation is an obvious underprediction of timeaveraged power for this group of test elements. This is not necessarily representative for the total group of 33 test elements; however, the RMS deviation of $\pm 12 \%$ between predicted and obtained test element power may be indicative of the achievable accuracy in lack of any other information (e.g., destructive burnup measurements). The observed deviations ranged between $+10 \%$ and $-24 \%$. 


\subsection{FISSION PRODUCT RELEASE AND REDISTRIBUTION}

One of the major goals of the EOL gamma scanning exercise was to determine the release and redistribution of relative fission products within the driver and test elements and possible migration through the sleeves into the primary circuit.

The total measured cesium inventory at EOL in each of the driver elements in both Phase I and Phase II is compared with the predicted Cs-137 inventory in Tables 10 and 11 . The predicted Cs-137 inventory was derived from the GAUGE FIMA and Eq. 19. Because of the direct relationship between FIMA and the Cs-137 inventory, the bias between the calculated and measured mean Cs-137 inventory was similar to the FIMA biases in Tables 8 and 9 on both an element-to-element basis and a core average basis. Because of the smaller uncertainty in the Cs-137 activity compared with deduced burnup values, there were 21 out of 48 elements which showed significant differences at the 0.05 level between measured and calibrated values using the individual agreement test (Eq. 20) as compared with the burnup comparison, where 14 out of 48 elements showed disagreement. On a core average basis, the group agreement test showed no difference between the measured and calculated values on the 0.05 significance level.

The following values were obtained:

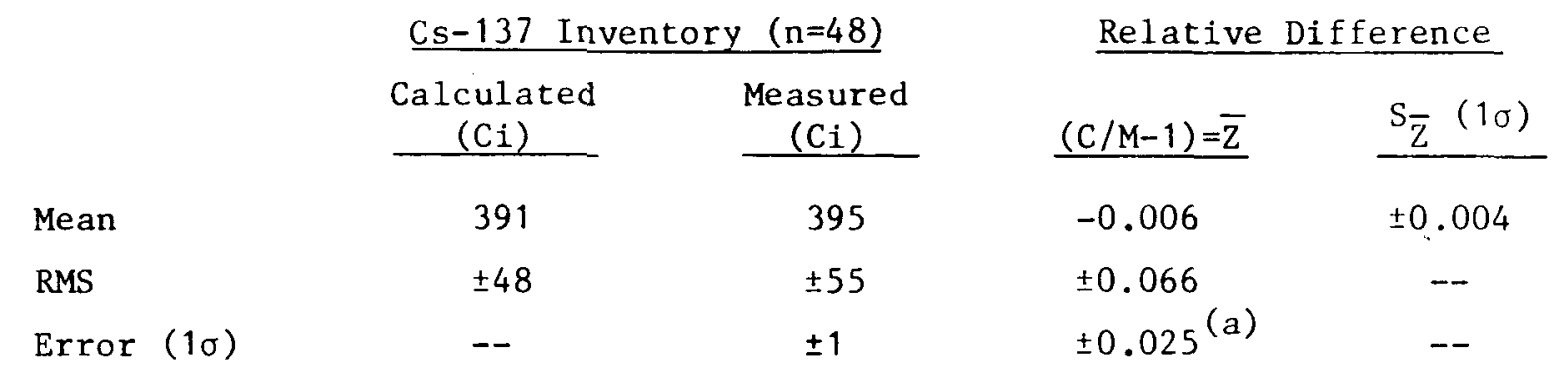

(a) Mean relative measurement error for individual driver elements. 
The numerical conclusions are that on a core average basis, the cesium inventory is predicted within $\pm 0.4 \%$ (the established bias of $-0.5 \%$ is within the $2 \sigma$ limit of the progressed measurement error and therefore is ignored). The element-to-element variation was established with $\pm 6.6 \%$, which again is larger than the mean relative measurement error of $\pm 2.5 \%$. The measurement uncertainty on the cesium inventory represents a fraction of $\pm 3.5 \times 10^{-3}$, which is a factor of 18 larger than the estimated core release (Ref. 14) of $2 \times 10^{-4 *}$ into the primary circuit.

An assumption in the measurement of the Cs-137 activity from the Peach Bottom gamma scans is that the $\mathrm{Cs}-137$ inventory is contained within the compact in a homogeneous manner. In reality, this is not true because the regions where $\mathrm{Cs}-137$ is lost from the compacts or built up on the sleeve and spine would be different from the calibrated geometry of a fuel compact with a homogeneous isotopic distribution. The impact of this effect is shown by the full element scanning of F03-01 at Peach Bottom and individual compact, sleeve, and spine scanning at ORNL. If the effect were large, the difference in the ORNL and Peach Bottom scans would be significant. In Table 12, the activity of each compact and the adjacent sleeve and spine sections as determined at ORNL are compared with FISS-PROD** predicted Cs -137 inventories and inventories determined from the Peach Bottom gamma scans, which were calibrated with the E14-01 inventory measurements at ORNL. The results are summarized below:

\begin{tabular}{lcc}
\multicolumn{1}{c}{ Method } & $\begin{array}{c}\text { Cs-137 Inventory } \\
(\mathrm{Ci})\end{array}$ & $\begin{array}{c}\text { Measurement } \\
\text { Error } \\
(\mathrm{Ci})\end{array}$ \\
\cline { 2 - 3 } GAUGE & 383.8 & ND \\
FISS-PROD** & 394.6 & ND \\
Peach Bottom & 404.8 & $\pm 7.1(1 \sigma)$ \\
ORNL & 404.2 & $\pm 3.2(1 \sigma)$
\end{tabular}

*Reference 14 assesses $65 \mathrm{Ci}$ of cesium released into the primary circuit, which represents a fraction of $2 \times 10^{-4}$ assuming a total core inventory of $3.2 \times 10^{5} \mathrm{Ci}$, based on the mean inventory per element times 804 elements. Some additional cesium was accumulated at reflector and control rod components, which was not accounted for in the 65-Ci estimate. **FISS-PROD is a one flux group depletion code. 
The good agreement between the ORNL and Peach Bottom determinations confirms the precision of the E14-01 and F03-01 inventory measurements at ORNL.

The axial distribution of the Cs-137 was also found to be in good agreement for the ORNL and Peach Bottom scans, as shown in Fig. 21. This comparison demonstrates that the Peach Bottom scanning accurately measured the cesium activity in elements that had significant cesium redistribution.

Reflector and control rod components were also gamma scanned and showed low Cs-137 contamination as follows:

\begin{tabular}{|c|c|c|c|c|c|}
\hline \multirow[b]{2}{*}{$\begin{array}{l}\text { Element } \\
\text { I.D. }\end{array}$} & \multirow[b]{2}{*}{$\begin{array}{l}\text { Element } \\
\text { Type }\end{array}$} & \multicolumn{2}{|c|}{$\begin{array}{l}\text { Cs-137 Activity } \\
\text { Above Background }\end{array}$} & \multicolumn{2}{|c|}{$\begin{array}{l}\text { Cs-134 Activity } \\
\text { Above Background }\end{array}$} \\
\hline & & $\begin{array}{l}\text { Mean } \\
\text { (CPM) }\end{array}$ & $\begin{array}{l}\text { Error } \\
(\%)(10)\end{array}$ & $\begin{array}{l}\text { Mean } \\
(\text { CPM })\end{array}$ & $\begin{array}{l}\text { Error } \\
(\%)(1 \sigma)\end{array}$ \\
\hline A18-08 & Reflector & 12.6 & \pm 4.3 & $<0.1$ & -- \\
\hline D18-12 & Reflector & $<0.3$ & & $<0.1$ & -- \\
\hline E17-16 & Reflector & 13.6 & $\pm 5.2^{(a)}$ & $<0.1^{(a)}$ & -- \\
\hline E08-01G & $\begin{array}{l}\text { Control rod } \\
\text { guide sleeve }\end{array}$ & 24.9 & \pm 4.6 & 37.4 & \pm 1.2 \\
\hline F08-01A & Control rod & 8.1 & \pm 5.7 & 1.8 & \pm 0.4 \\
\hline
\end{tabular}

(a) Using average background from A18-08 and D18-12.

The control rod sleeve (E08-01G) had the highest cesium levels above the background. Because there is no quantitative calibration for the scanning of these reactor components, an assessment of the magnitude of the cesium accumulation cannot be made until some calibration has been done on reflector A18-08, which was shipped to ORNL for PIE. On a semiquantitative basis the buildup would be small, because $20 \mathrm{CPM}$ of $\mathrm{Cs}-137$ corresponds to $<1 \%$ of the activity seen in a standard driver element, which is $\sim 5 \mathrm{Ci}$. 
Low release was also evident from the scan of the fission product trap in each of the driver elements (see Tables 10 and 11). In all cases except two, the cesium activity in the trap was only slightly above the background. In E04-02 and E09-02, the activity in the trap was an order of magnitude higher than for the rest of the elements. Using the detector calibration for the fuel scanning, there was a 7- to 9-Ci buildup of both Cs-137 and Cs-134 in each trap. This corresponds to approximately $2 \%$ of the total cesium inventory in these two particular elements; however, these values have to be confirmed by inventory measurements for specific fission product traps at ORNL.

The redistribution of mobile fission products in the elements is characterized by the predicted and measured profiles of these isotopes. In the case of Cs-137, the predicted values from the FISS-PROD (Ref. 16) ca1culations are a good representation of the non-distributed profile because the long half-life of Cs-137 (30.1 yr) is not seriously affected by the detailed power history of the element.

Only the Cs-137 was calculated with FISS-PROD owing to the simplicity of this one-dimensional depletion code, which does not accurately predict short-lived isotopes. All other isotopes will be analyzed qualitatively by their profiles and in comparison with non-releasing isotopes. The FISS-PROD determined relationship between fluence and Cs-137 activity produced is shown in Fig. 22.

The redistribution of $\mathrm{Cs}-137$ within the driver elements appears to correlate with core location, which is explainable by the fuel element temperature. The difference in $\mathrm{Cs}-137$ redistribution is illustrated graphically in Fig. 23. These plots show the measured and predicted Cs-137 inventory for E01-01, E03-02, E06-02, E09-01, E11-01, and E14-01, which covered the radius of the core. In Tables 13 through 18, the quantitative difference between the measured and calculated Cs-137 inventories is given. From the comparison of the six elements it is obvious that the Cs -137 distribution is similar in all elements. Generally, the highest Cs-137 loss 
occurs in the upper portion of the element near compacts 18 through 22 , and thus Cs-137 is subsequently transported downward by the purge stream until it accumulates on cooler surfaces. The maximum accumulation occurred between compacts 2 through 8 in the six fuel elements analyzed. To show that this behavior is consistent for other radial sections through the core, the plots of Cs-137 activity of F02-01, F04-03, and F15-14 are given in Fig. 24. Again, the Cs-137 redistribution is seen to increase with locations nearer the center of the core. The three plots in Fig. 24 also show the measured activity of $\mathrm{Cs}-134$. It is obvious from the profiles that both isotopes of cesium redistribute themselves in the elements in a similar fashion.

To further illustrate the core location* effect and Cs-137 loss in the upper high-temperature region of the driver elements, a plot of core locations versus maximum $\mathrm{Cs}-137$ loss is shown in Fig. 25. With few exceptions, increasing $\mathrm{Cs}-137$ release was found for compacts 15 through 22 with decreasing distance from the core center.

Cs-137 redistribution data for E01-01, E03-02, E06-02, E09-01, E11-01, and E14-01 from Tables 13 through 18 were used in a correlation of Cs-137 release to fuel temperature within the element. The time-averaged SURVEY (Ref. 17) calculated fuel temperatures (Table 19) for several of the compacts in each element are plotted against the relative $\mathrm{Cs}-137$ difference in that compact in Fig. 26. This plot shows a noticeable loss of Cs-137 from the compacts starting at approximately $1060^{\circ} \mathrm{C}$ (time-averaged temperature). Above this temperature the magnitude of the loss increased but appeared to be somewhat random. The scatter in the data is attributed to the uncertainty in the measurements and in the SURVEY-calculated temperatures, which have an intrinsic error and are not fully representative of the diffusive release of Cs-137; in fact, the activation-energy time-weighted temperature should be used in the comparison of the Cs-137 diffusive process as explained in Ref. 4. The time-weighted temperature is used only for illustrative furposes in this particular analysis.

* Core radial location is defined by the first two digits of the element identity. For example, the core location for F06-02 is 06 . This number is directly related to the distance from the center of the core, which varied between 01 to 17 . 
Another analysis was performed on all the driver elements to summarize the effect of Cs-137 redistribution within the core. For all driver elements, the maximum Cs-137 buildup and release areas were determined and related to the time-averaged temperatures in Tables 20 and 21 . Several conclusions were drawn from this analysis:

1. Maximum $\mathrm{Cs}-137$ plateout occurred in compacts 5 to 14 , and maximum Cs-137 loss occurred in compacts 15 to 25 .

2. The time-averaged temperature of the fuel where Cs-137 1oss was greatest was $1100^{\circ} \mathrm{C}$ with an RMS of $\pm 30^{\circ} \mathrm{C}$ for 37 driver elements that showed Cs-137 loss. This generally corresponded to the location of peak fuel temperature of the elements (see Fig. 26).

3. The Cs-137 plateout occurred in regions with fuel temperatures of $936^{\circ} \mathrm{C} \pm 81^{\circ} \mathrm{C}$ (RMS) and maximum EOL sleeve temperatures of $652^{\circ} \mathrm{C} \pm 46^{\circ} \mathrm{C}$ (RMS).

The redistribution and loss of other radionuclides were also considered; specifically, cesium, ruthenium, and iodine isotopes were tested for mobility. The mobility tests were performed in fuel elements using several nonreleasing fuel elements as internal standards. The criterion for loss or movement was deduced from a comparison of isotopic ratios between a mobile and a non-mobile isotope; $\mathrm{Zr}-95$ was chosen as a non-mobile isotope. A description of the test statistic is given in Ref. 4.

FISS-PROD calculations of the isotopic inventories of a fuel compact at various thermal fluence exposures showed that the isotopic ratios changed from $5 \%$ to $20 \%$ within the thermal fluence exposure of the fuel driver elements. Therefore, a correlation of thermal fluence versus isotopic ratios can be established when comparing a non-releasing element with elements suspected of release. 
The ratios chosen for the initial analysis were $\mathrm{Ce}-141 / \mathrm{Zr}-95, \mathrm{Ru}-103 /$ $\mathrm{Zr}-95$, and $\mathrm{I}-131 / \mathrm{Zr}-95$. Ru-106 and $\mathrm{Ce}-144$ were not chosen for mobility tests because of the low fission yield of $\mathrm{Ru}-106$ and because of the low absolute gamma ray intensity for $\mathrm{Ce}-144$, which resulted in low activities and high counting errors. E01-01 was the element used for a test of mobility of the three isotopes in question, because it was one of the Cs-137 redistributing elements scanned first during Phase I. The short cooldown time for this element allowed good discrimination for short half-lived isotopes, especially I-131. During Phase II of the gamma scanning, I-131 and Ce-141 activity was not detected owing to their short half-lives and consequently low activity levels after a 7 -month decay.

E14-01 was considered to be a non-releasing element from gamma scanning evidence at ORNL (Ref. 12) and the Peach Bottom gamma scanning, which indicated no cesium loss or redistribution (see Section 3.4); it was therefore used to determine the relationship between fluence and isotopic ratios. A14-14 and E13-01 were also chosen from Phase II gamma scanning to add additional data to the Ru-103/2r-95 ratio versus thermal fluence data. I-131 and Ce-141 distribution profiles were limited to data for these isotopes from Phase I gamma scanning, which had only E14-01 as a non-releasing element with the standard fuel loading $(45.792 \mathrm{~g} \mathrm{Th}, 8.318 \mathrm{~g} \mathrm{U})$. The highthorium-loaded (Th:U atomic ratio of $18.5: 1$ ) fuel elements in Phase I did not show Cs-137 redistribution, but were not analyzed for other isotopic movement.

The data of GAUGE/FEVER calculated thermal fluence versus the various isotopic ratios from E04-01, A14-14, and E03-01 are shown in Figs. 27 through 29. A least squares fit was determined for each set of data, and this was used for the non-releasing base lines of Ce-141/Zr-95, I-131/Zr-95, and $\mathrm{Ru}-103 / \mathrm{Zr}-95$. The $95 \%$ confidence 1 imits on this 1 inear regression were determined via algorithms described in Ref. 4.

Using these ratio-fluence relationships, the non-releasing base lines with their $95 \%$ confidence levels are compared with the measured ratios in 
Figs. $30(a)$ and 31 (a) for E01-01, which was shown to be a high-releasing element, as discussed in Section 3.4.

In all cases the measured and non-releasing base lines were within the $95 \%$ confidence levels of each other. The conclusion is that within the $2 \sigma$ uncertainties of the counting errors, Ce-141, Ru-103, and I-131 isotopes were not mobile in the Peach Bottom driver elements. The absolute isotopic profiles of these three elements, which are shown in Figs. $30(\mathrm{~b})$ through 32 (b), were relatively smooth with no major perturbations, which is further evidence of no fission product mobility of Ce-141, Ru-103, or I-131.

\subsection{THORIUM ABSORPTION RATES}

Mathematically, the Pa-233 concentration is shown to be related to the thorium absorption by

$$
\frac{\mathrm{dN}_{\mathrm{Pa}-233}}{\mathrm{dt}}=-\lambda \cdot \mathrm{N}_{\mathrm{Pa}-233}+\sigma_{\mathrm{a}} \mathrm{N}_{\mathrm{Th}-232} \phi,
$$

where

$$
\begin{aligned}
\phi & =\text { neutron flux, } \\
\mathrm{N}_{\mathrm{Pa}-233}= & \text { number of nuclei of } \mathrm{Pa}-233 \text { formed, } \\
\sigma_{\mathrm{a}} \mathrm{N}_{\mathrm{Th}-232} \phi= & \text { absorption rate of } \mathrm{Th}-232, \\
\sigma_{\mathrm{a}}= & \text { microscopic cross section for absorption reactions in } \\
& \mathrm{Th}-232, \\
\lambda^{-}= & \lambda+\sigma_{\mathrm{a}} \phi, \\
\lambda= & \text { decay constant of } \mathrm{Pa}-233 .
\end{aligned}
$$

All the Pa-233 normalized profiles in the fuel driver elements were smooth and had small counting errors. The GAUGE/FEVER calculated normalized 
absorption rate for E14-01 is compared with the Pa-233 normalized profile in Fig. 33. The measured and calculated profiles agree closely except for a shift in peak toward the bottom of the core.

The radial distribution of $\mathrm{Pa}-233$ in the core was also compared with the GAUGE-calculated EOL thorium absorption rate for driver elements that were located away from the control rods. Figures 34 and 35 show the calculated and measured comparison for Phase I and Phase II driver elements, respectively. In both cases the measured radial profiles of Pa-233 were flatter than the predicted profile, which may be explainable by the shift in radial power distribution toward EOL due to control rod withdrawal, as discussed in Section 3.2.2. 


\section{CONCLUSIONS}

The Peach Bottom EOL gamma scanning exercise of driver elements, test elements, reflector elements, and a control rod with sleeve was done to provide a data base of information on fission product distribution in the Peach Bottom core for use in validating nuclear physics and thermal performance and fission product release codes. The analysis of the gamma spectroscopic data allows conclusions about burnup, power and thorium absorption profiles, fission product release and redistribution trends, and fuel stack length dimensional changes. The conclusions from these findings are summarized below:

1. Fuel stack dimensional changes of the fuel driver elements showed an average increase of $0.7 \%$ in length, which is within the design criterion of the elements. This stack expansion tended to increase with both higher temperatures and fast fluences. Most of the fuel test elements showed a shrinkage in their fuel stacks of $-0.5 \%$ to $-2 \%$.

2. Normalized axial and radial Cs-137 profiles in the core properly predicted the corresponding axial and radial time-averaged power distributions.

3. The shape and peak shift in the FEVER-calculated EOL axial power profiles were reasonably well predicted by the normalized $\mathrm{Zr-95}$ and La-140 distributions. Radial EOL power profiles were also approached by the normalized radial La-140 and 2 r-95 profiles.

4. The influence of control rod withdrawal on the EOL power shape of nearby elements was reflected in different La-140 and $2 r-95$ axial profiles. 
5. Measured burnup from the Cs-137 inventory and GAUGE-calculated burnups of the driver and test elements were within $\pm 6.8 \%$ (10) of each other on an element-to-element basis. This agreement is better than the generally stated accuracy of $\pm 10 \%$ for nuclear predictions. The relative difference of the measured and calculated burnups on a core average basis for 48 driver elements was within the progressed uncertainty of the measurements $[+0.7 \%(1 \sigma)]$.

6. Cesium inventory measurements resulted in agreement with predictions within $\pm 0.4 \%$ on a core average basis and within $\pm 6.6 \%$ on an element-to-element basis. The measured cesium inventory was associated with a relative error of $\pm 3.5 \times 10^{-3}$, which is above the estimated fractional release (excluding accumulation of cesium in reflector and control rod components) of $2 \times 10^{-4}$ into the primary circuit; i.e., the cesfum release was undetectable within the sensitivity of the measurement method.

7. Ten isotopes were systematically analyzed, and only Cs-137 and Cs-134 were found to be released and redistributed within the element. In the case of Cs-137 there was no detectable release from the driver elements within the measurement uncertainties, although Cs-137 and Cs-134 did redistribute within the fuel elements. This was characterized by release in the locations of high fuel temperatures in the upper portions of the driver element and movement down the purge stream to the cooler sleeve, spine, and compact surfaces where accumulation occurred.

8. Of the non-fueled components scanned (i.e., reflectors, control rod, and control rod sleeve), only the control rod sleeve showed some Cs-137 and Cs-134 contamination. The activity on this sleeve was approximated to be $<1 \%$ of total activity in one driver element, or $<5 \mathrm{Ci}$. 
9. The Pa-233 normalized activity profile was found to follow the predicted GAUGE/FEVER thorium absorption profiles except for a slight shift of the peak toward the bottom of the core. Measured radial core $\mathrm{Pa}-233$ profiles were found to be flatter than the calculated EOL thorium absorption rates, which may be related to the change in power distribution toward EOL due to control rod removal. 


\section{ACKNOWLEDGMENTS}

The authors would like to acknowledge the support and advice of all the individuals involved with this report. Special thanks go to Paul Love and Andy Valenciano for their patience and overtime efforts to complete the PBEOLGS data reduction program that made this report possible. John Saurwein is also thanked for his helpful discussions and data input; Frank Dyer, ORNL, is acknowledged for the calibration work (Ref. 12), which formed the basis for the quantitative analysis in this report; and Art Mehner is thanked for the coordination of the data collection at the site. Other contributors are as follows:

\section{Data Collection}

V. Orphen, V. Rodger, J. Mackenzie, A. Wyman, and D. Bryan of the Intelcom Rad Tech staff; W. Birely and associated Philadelphia Electric staff at Peach Bottom; L. Mayweather, D. Harmston, R. DeNooy, K. Buthe, J. Graves, A. Wyman, J. Renauld

\section{Data Reduction}

E. Anderson, D. Hill, A. Bagierek, R. Archibald, W. Lefler, M. Scott

\section{$\underline{\text { Report Preparation }}$}

D. Novak, J. Baker, J. Weaver and staff 


\section{REFERENCES}

1. Philadelphia Electric Company, "Final Hazards Summary Report, Peach Bottom Atomic Power Station," Vol. II, 1964.

2. Mehner; A. S., "Test Plan for Gamma Scanning Peach Bottom Test and Driver Elements," General Atomic Company, unpublished data.

3. Hick, H., and J. York, "Metallic Fission Product Behavior in Dragon Fuel Elements as Observed from Gamma-Spectrometric Examination," Dragon Report DPTN/5-13, November 5, 1973.

4. Wallroth, C. F., J. F. Holzgraf, and D. D. Jensen, "Postirradiation Examination and Evaluation of Peach Bottom Fuel Test Element FTE-6," ERDA Report GA-A13943, September 1977.

5. Meek, M. E., and B. F. Rider, "Compilation of Fission Product Yields," Vallecitos Nuclear Center Report NEDO-12154-1, 1974.

6. Evaluated Nuclear Data File Library, ENDF/B, Version IV, Brookhaven National Laboratory.

7. Anderson, E. E., "Method of Data Reduction for Peach Bottom Gamma Scan," General Atomic Company, unpublished data.

8. Scheffel, W. J., et al., "Peach Bottom 150 Full-Power Day Core Examinations," General Atomic Report GAMD-8703, December 1968.

9. Wallroth, C. F., et al., "Postirradiation Examination and Evaluation of Peach Bottom Molded Fuel Test Element FTE-18," General Atomic Report GA-A13699, June 1, 1976.

10. Archibald, R., General Atomic Company, private communication, February 1976.

11. Love, P., and A. Valenciano, "PBEOLGS, A Program for Peach Bottom EOL Gamma Scan Analysis," General Atomic Company, unpublished data.

12. Wichner, R. P., et al., "Distribution of Fission Products in Peach Bottom HTGR Fuel Element E14-01," ERDA Report ORNL/TM 5730, Oak Ridge National Laboratory, August 1977. 
13. Holzgraf, J. F., et al., "Postirradiation Examination and Evaluation of Peach Bottom Fuel Test Elements FTE-14 and 15," General Atomic Report GA-A13944, to be published.

14. Hanson, D. L., N. L. Baldwin, and W. E. Selph, "Gamma Scanning the Primary Circuit of the Peach Bottom HTGR," General Atomic Report GA-A14161, October 31, 1976.

15. "Reactor Burn-up Physics," in Proceedings of a Panel on Reactor Burn-up Physics, a Conference Organized by the International Atomic Energy Agency and Held in Vienna, July 12-16, 1971, IAEA, Vienna 1973.

16. Crockett, T., General Atomic Company, private communication, June 1977.

17. Saurwein, J. J., "Peach Bottom Test Element Thermal Analyses with TREVER Code," General Atomic Company, unpublished data. 
APPENDIX A

FIGURES

A-1 


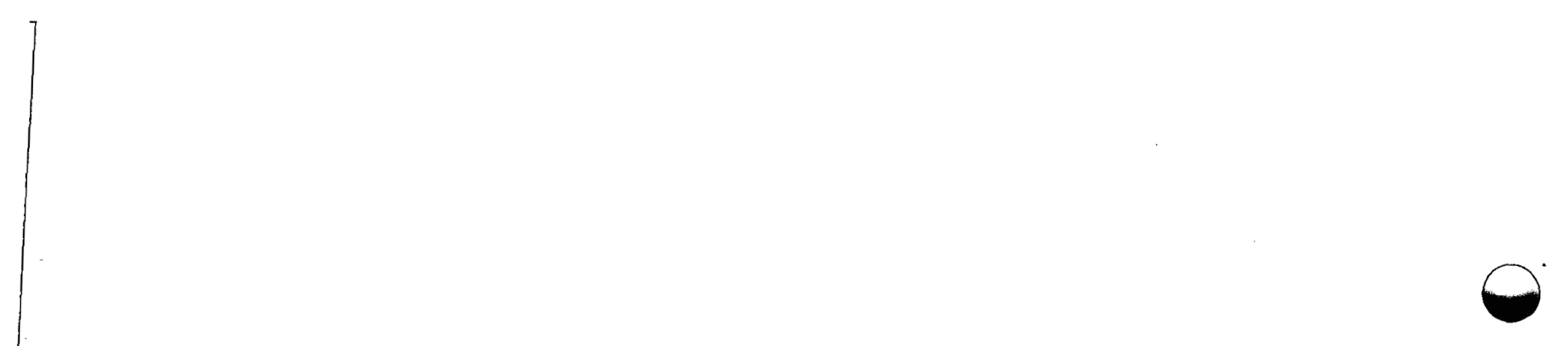

$\vartheta$ 


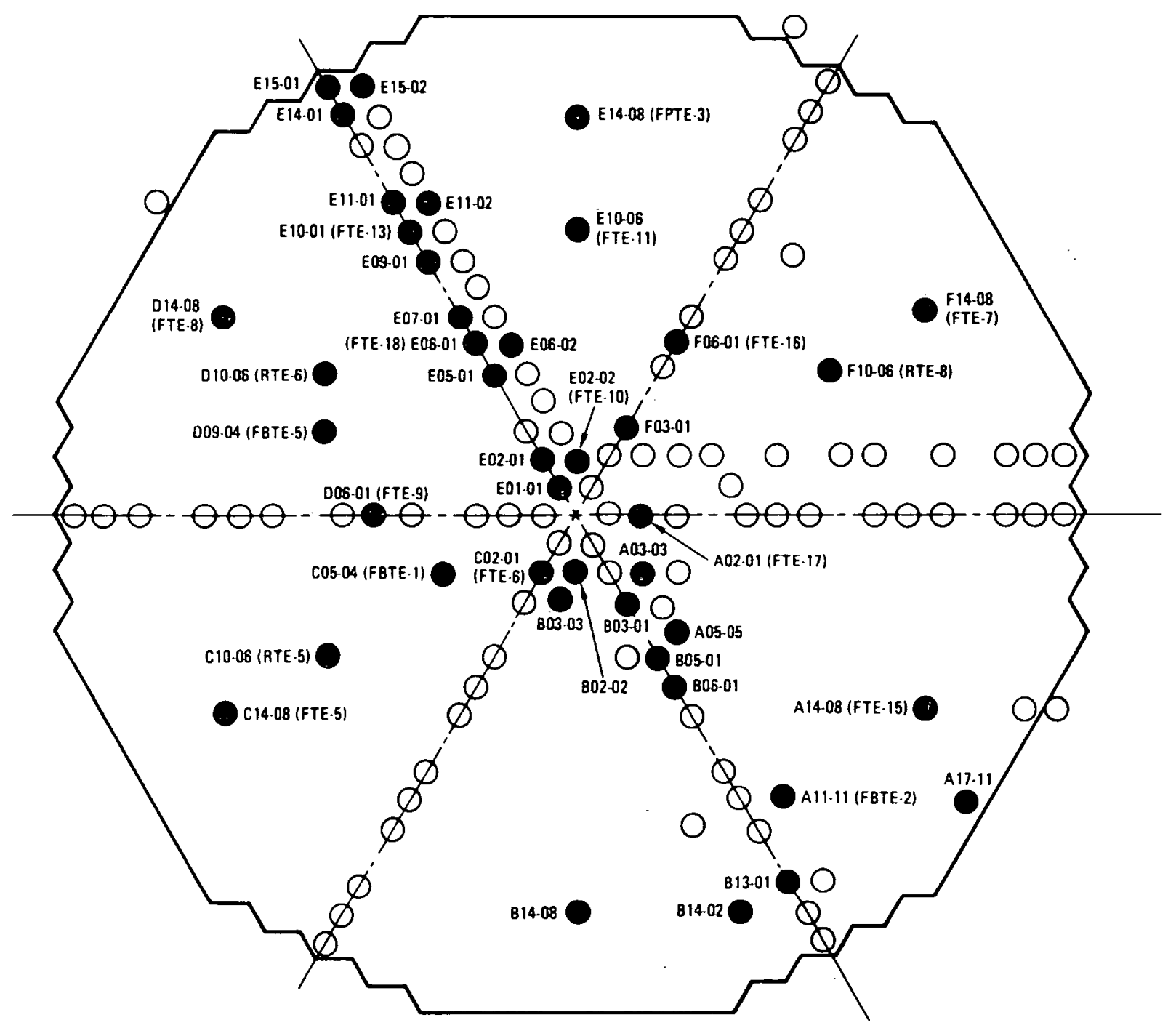

Fig. 1. Peach Bottom elements scanned during Phase I 


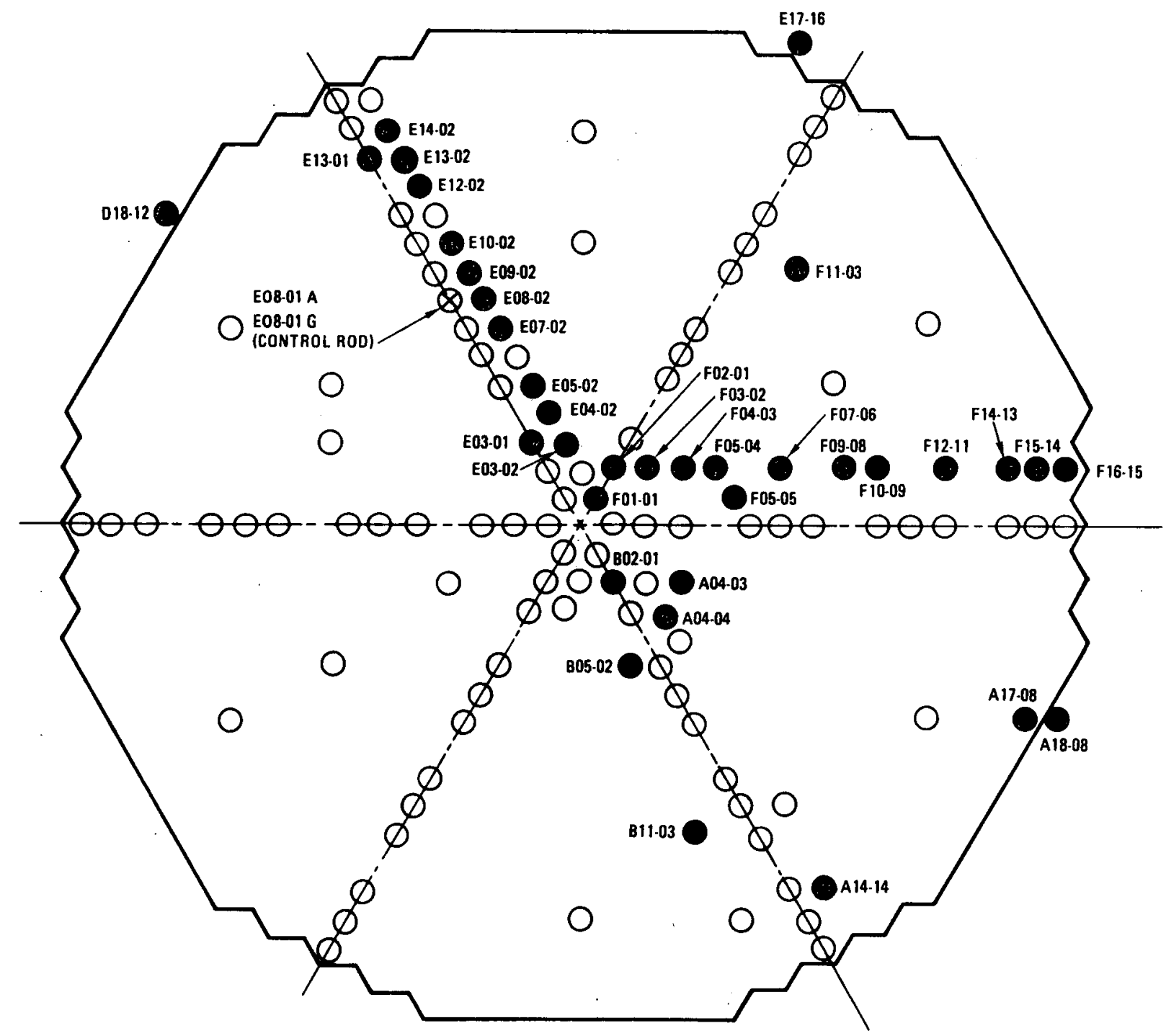

Fig. 2. Peach Bottom elements scanned during Phase II 


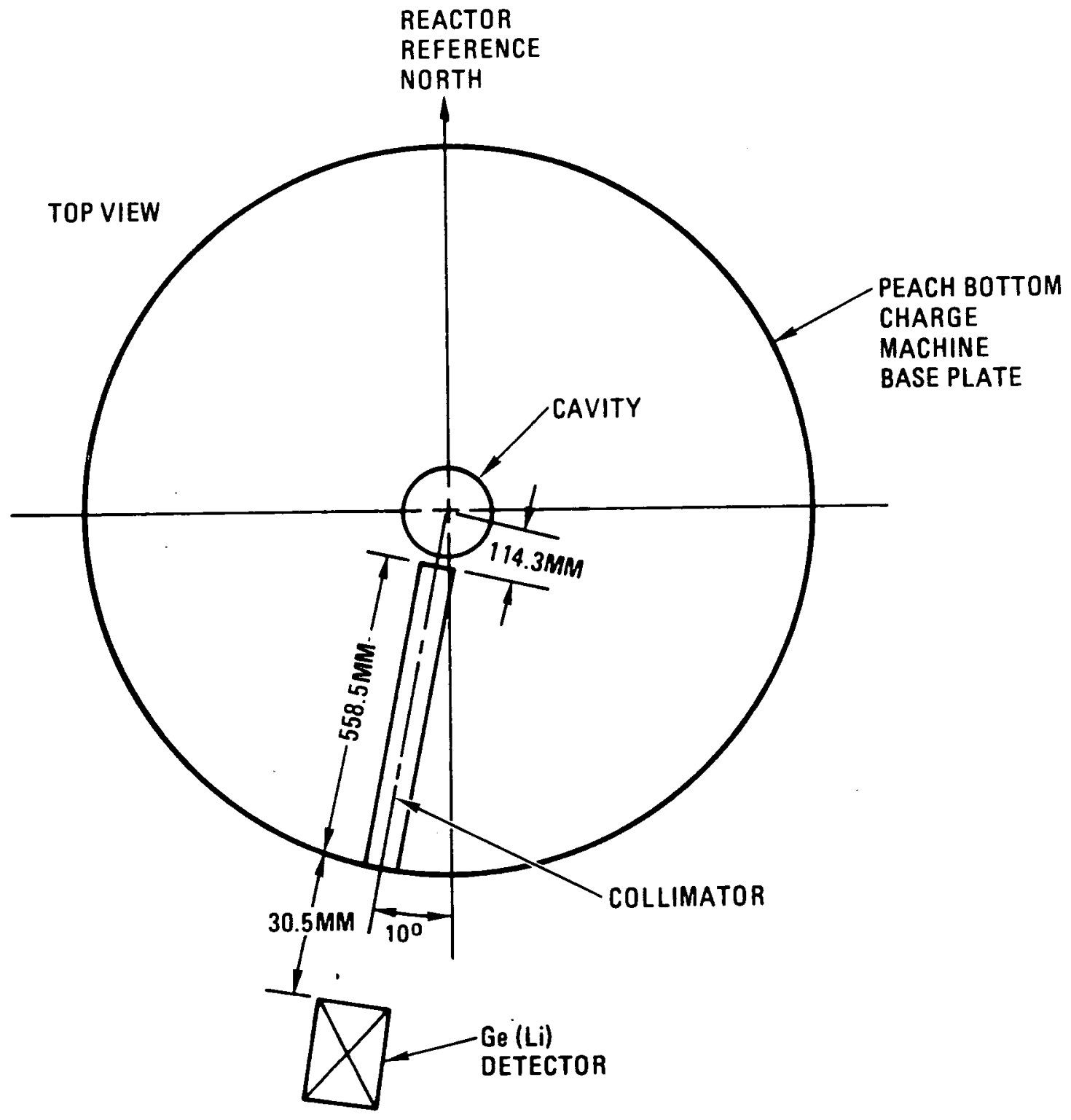

Fig. 3. Collimator geometry in Peach Bottom charge machine 


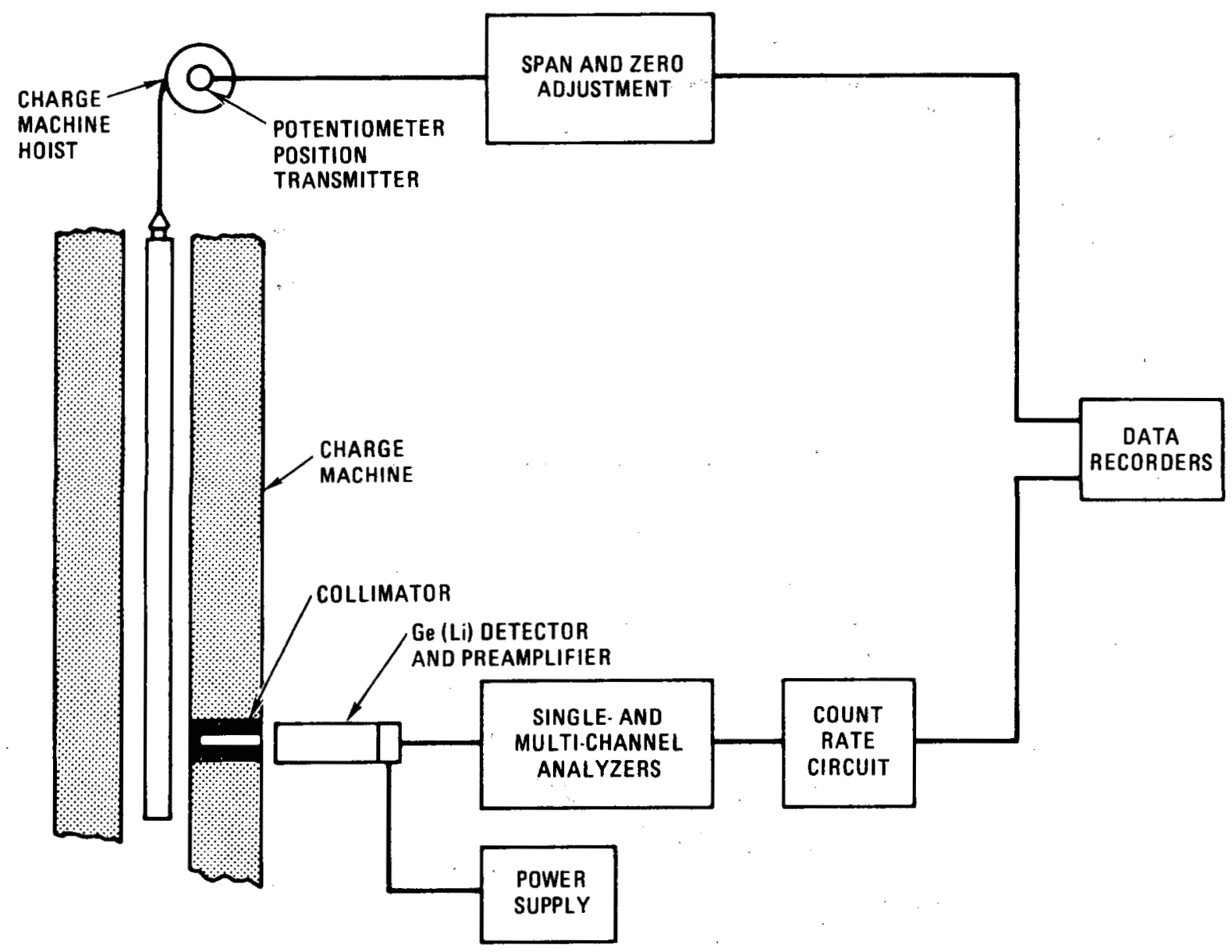

Fig. 4. Test arrangement for gamma scanning Peach Bottom test and driver fuel elements 


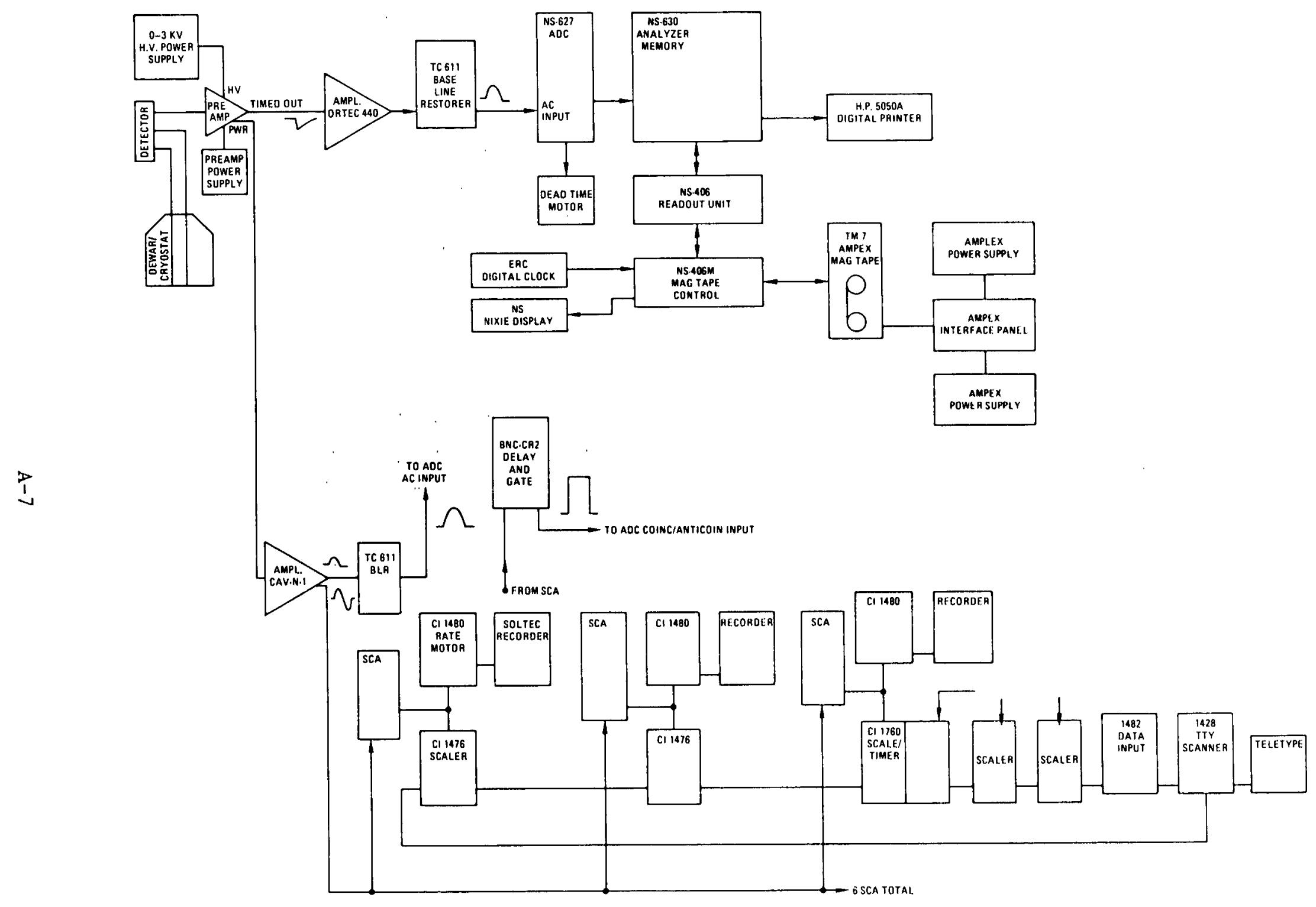

Fig. 5. Electrical schematic of Peach Bottom gamma scanning equipment 

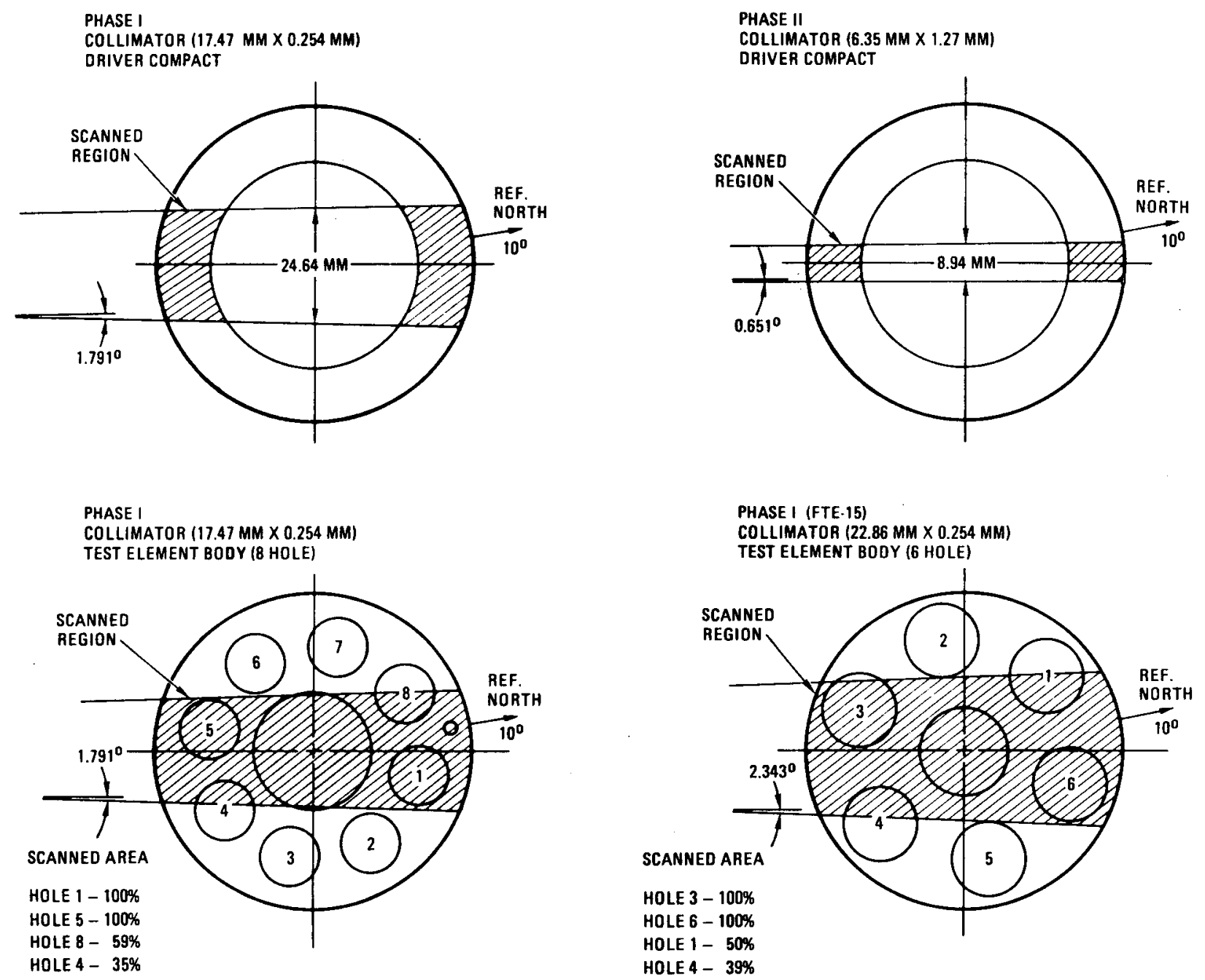

Fig. 6. Effective scanning paths of Peach Bottom EOL gamma scanning 


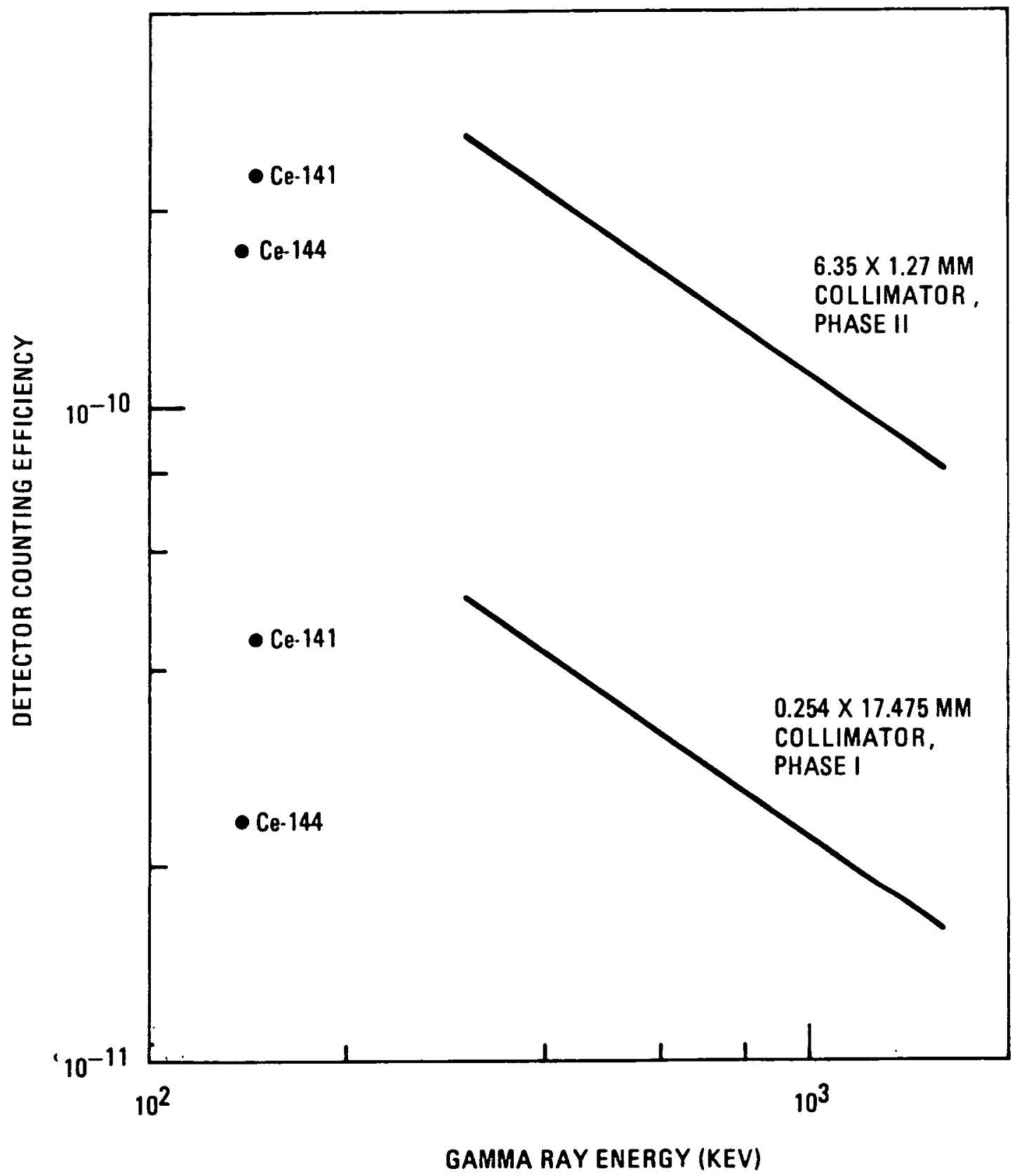

Fig. 7. Detector counting efficiency for Phase I and Phase II gamma scanning 
$\bullet$

$\theta$ 


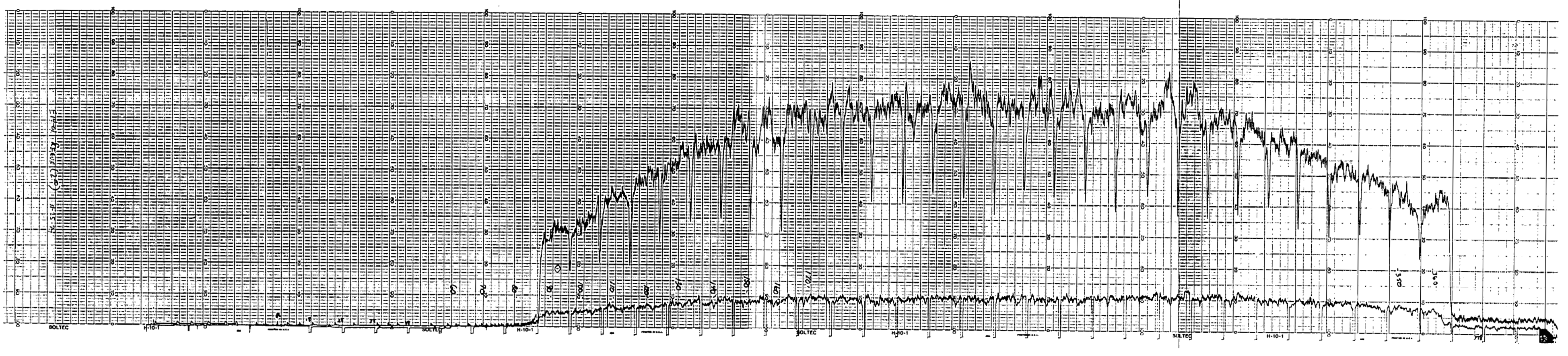

Fig. 8. E14-01 strip chart recording of $\mathrm{Cs}-137$ 


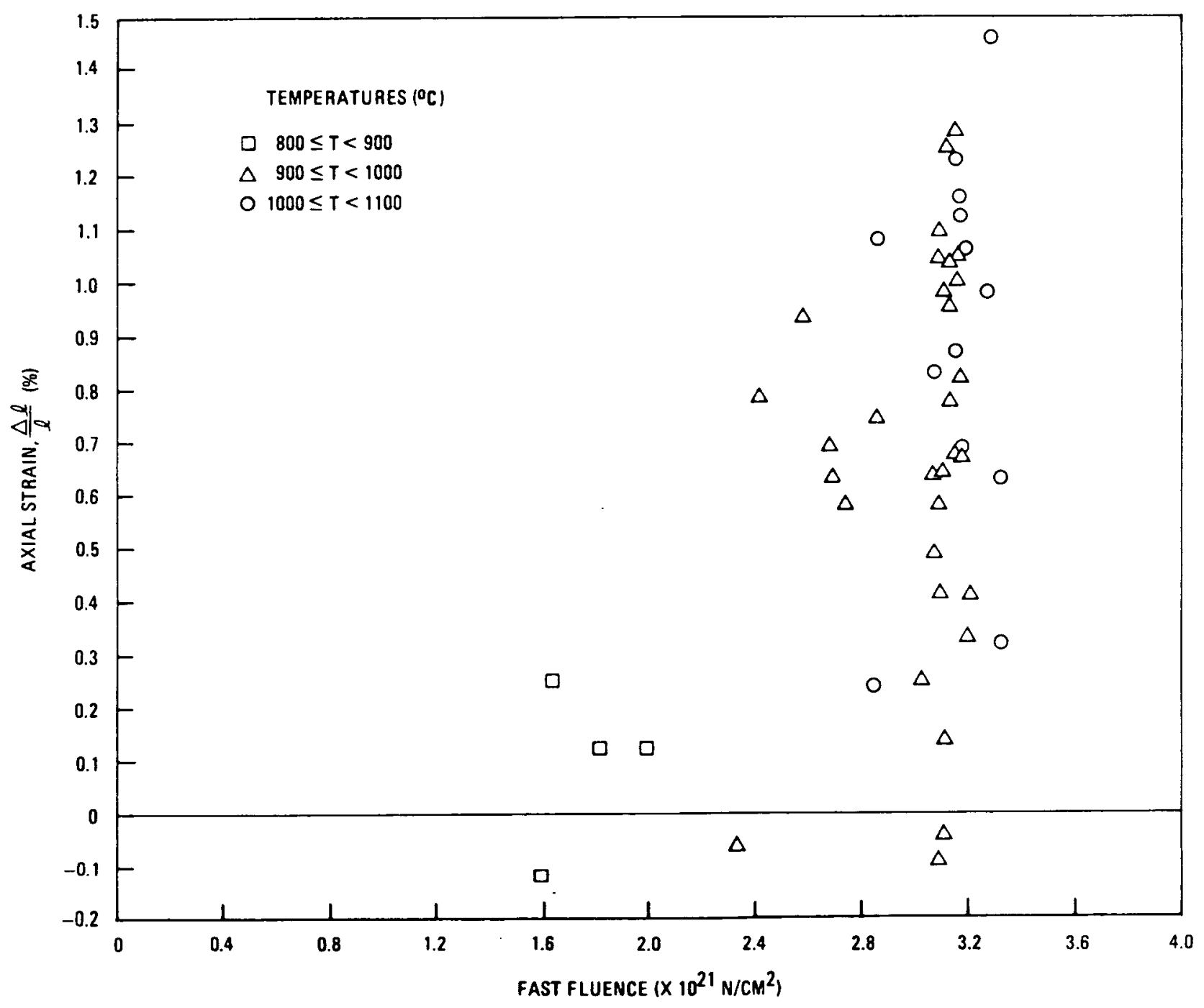

Fig. 9. Measured axial strain versus fast fluence at various timeaveraged temperature ranges 


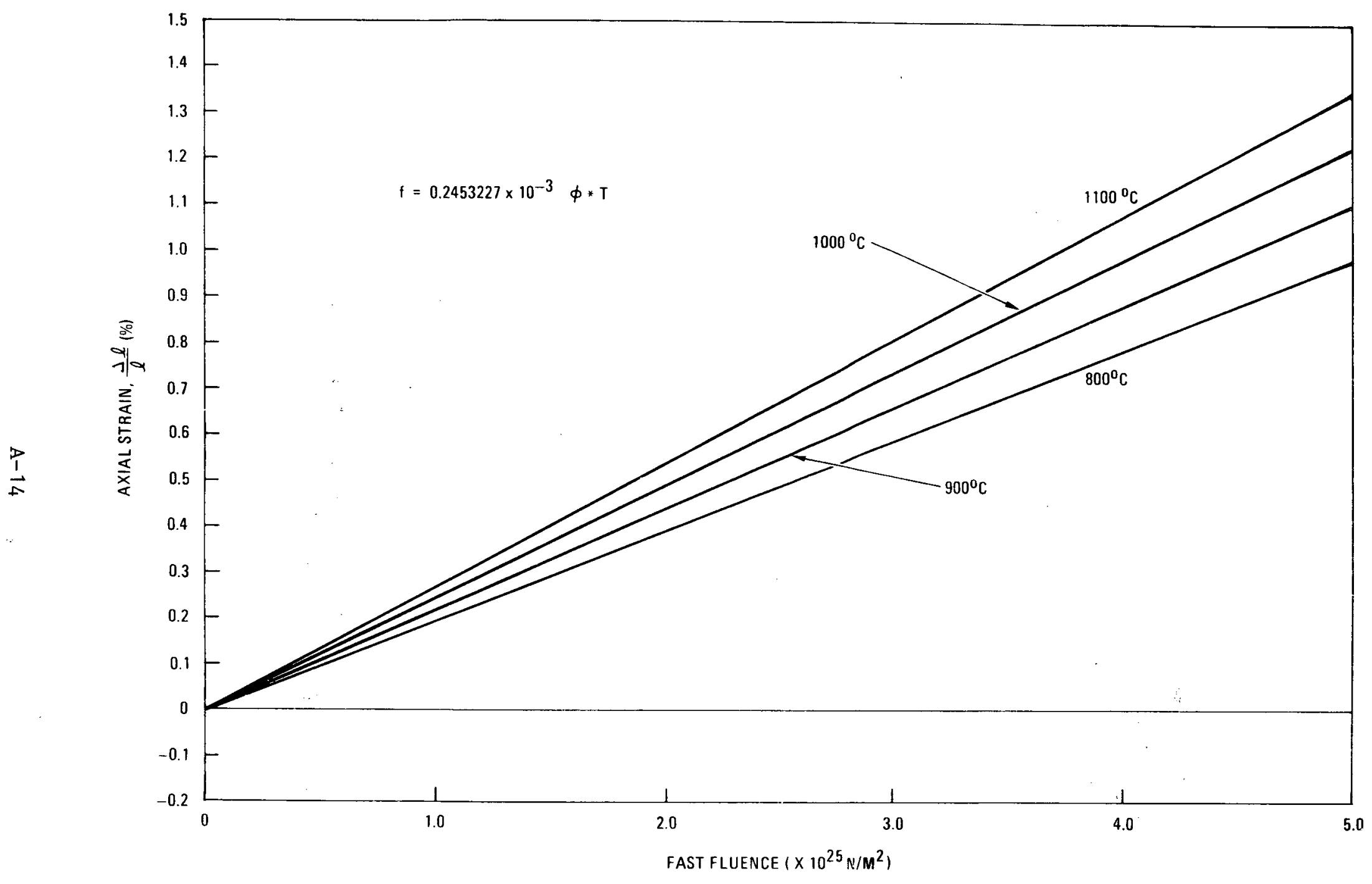

Fig. 10. Fitted axial strain versus fast fluence at various temperatures 


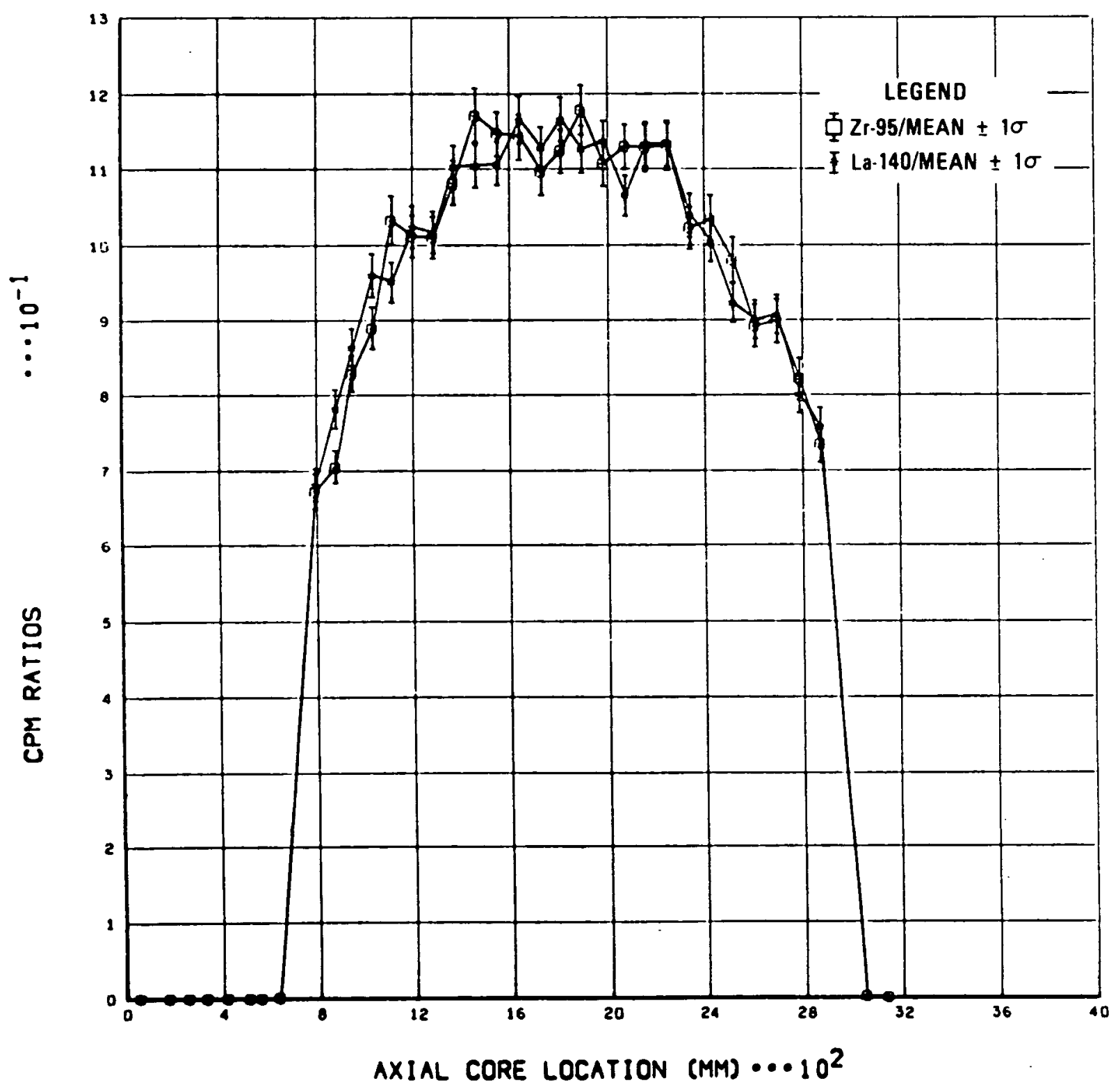

Fig. 11. Normalized nuclide CPM ratio axial profiles of $\mathrm{Zr}-95$ and La-140 for E14-01

$$
\text { A-15 }
$$




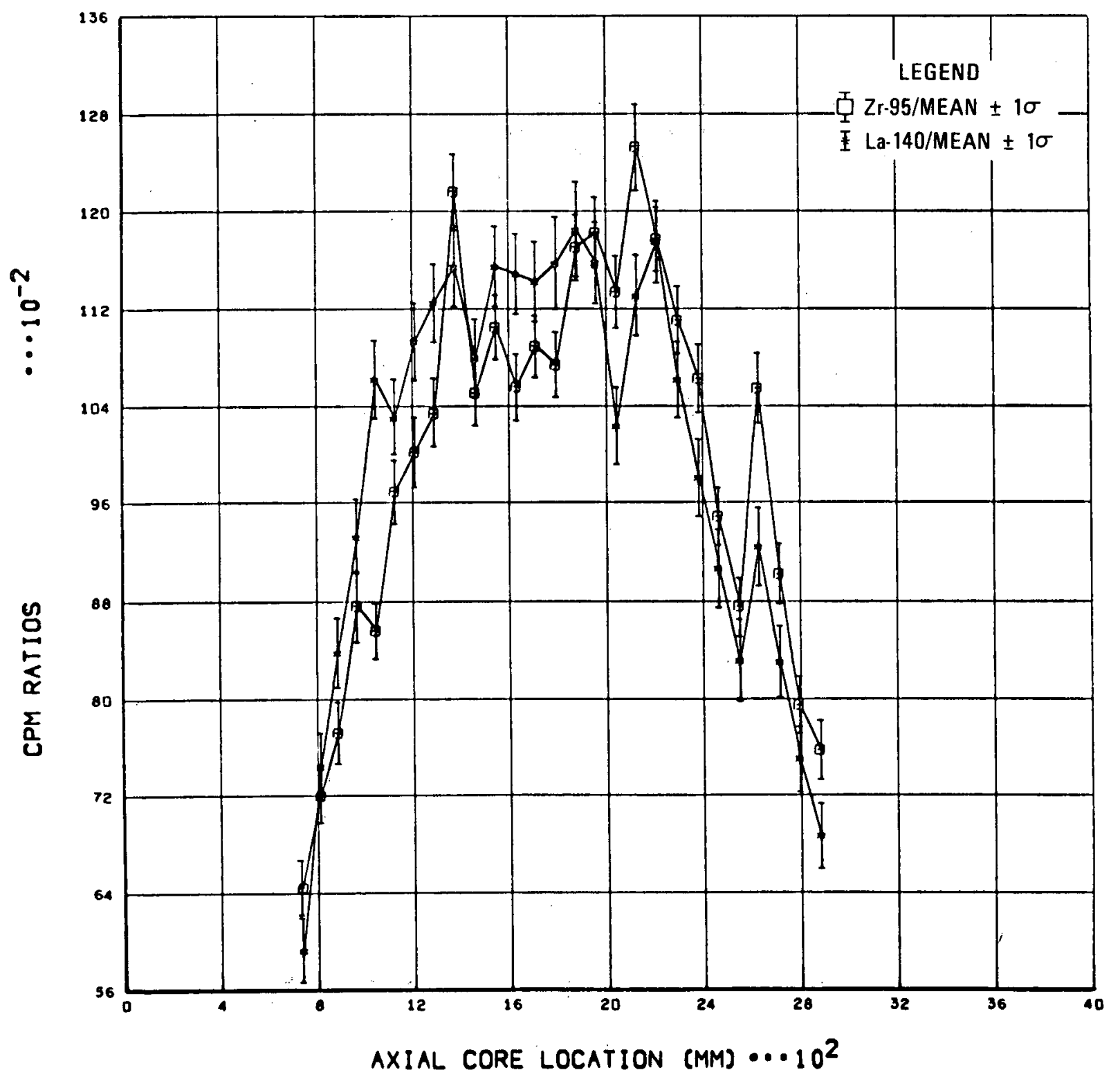

Fig. 12. Normalized nuclide CPM ratio axial profilés of $\mathrm{Zr}-95$ and La-140 for F03-01 


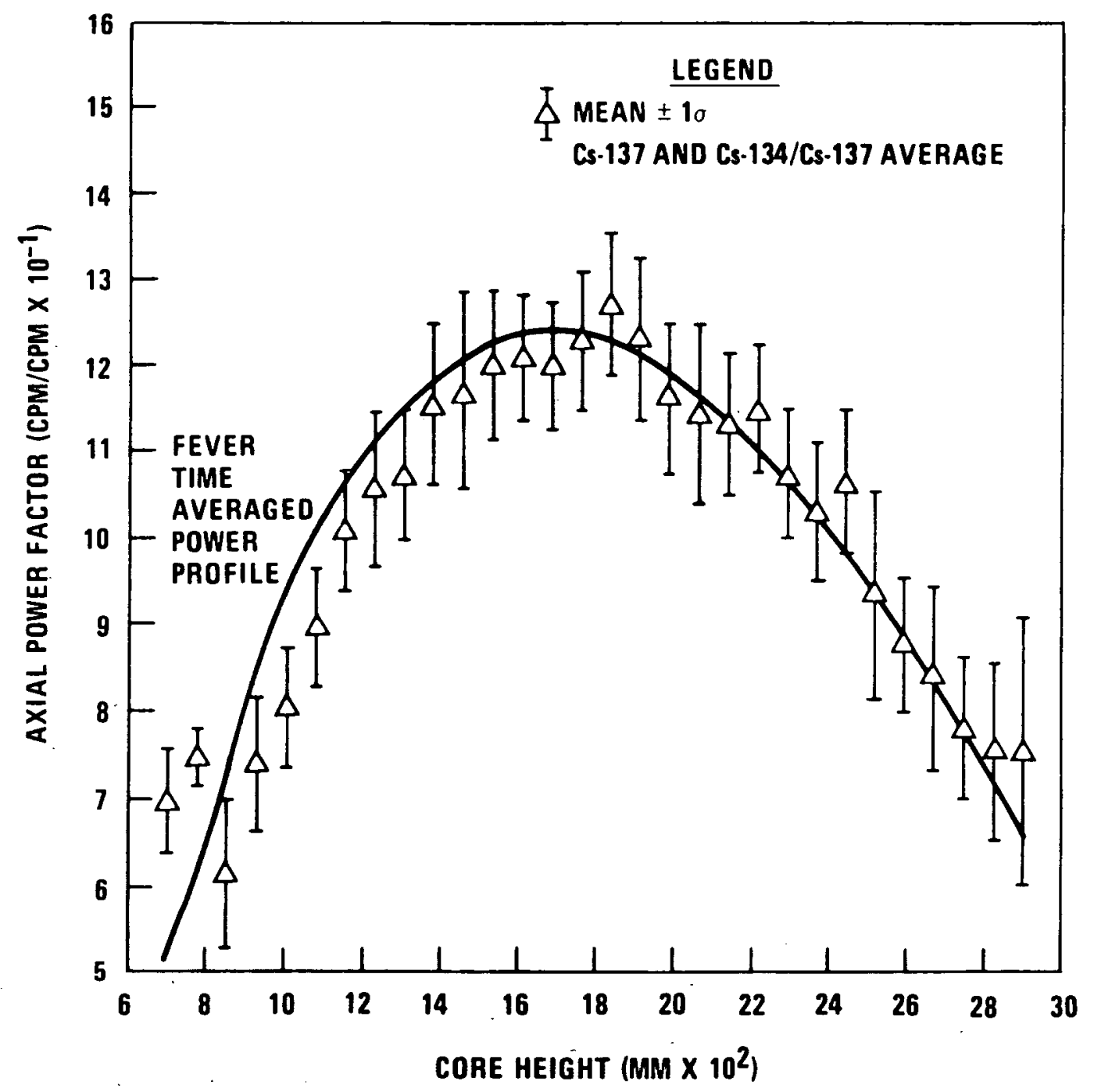

Fig. 13. FEVER time-averaged power profile comparison for E14-01 


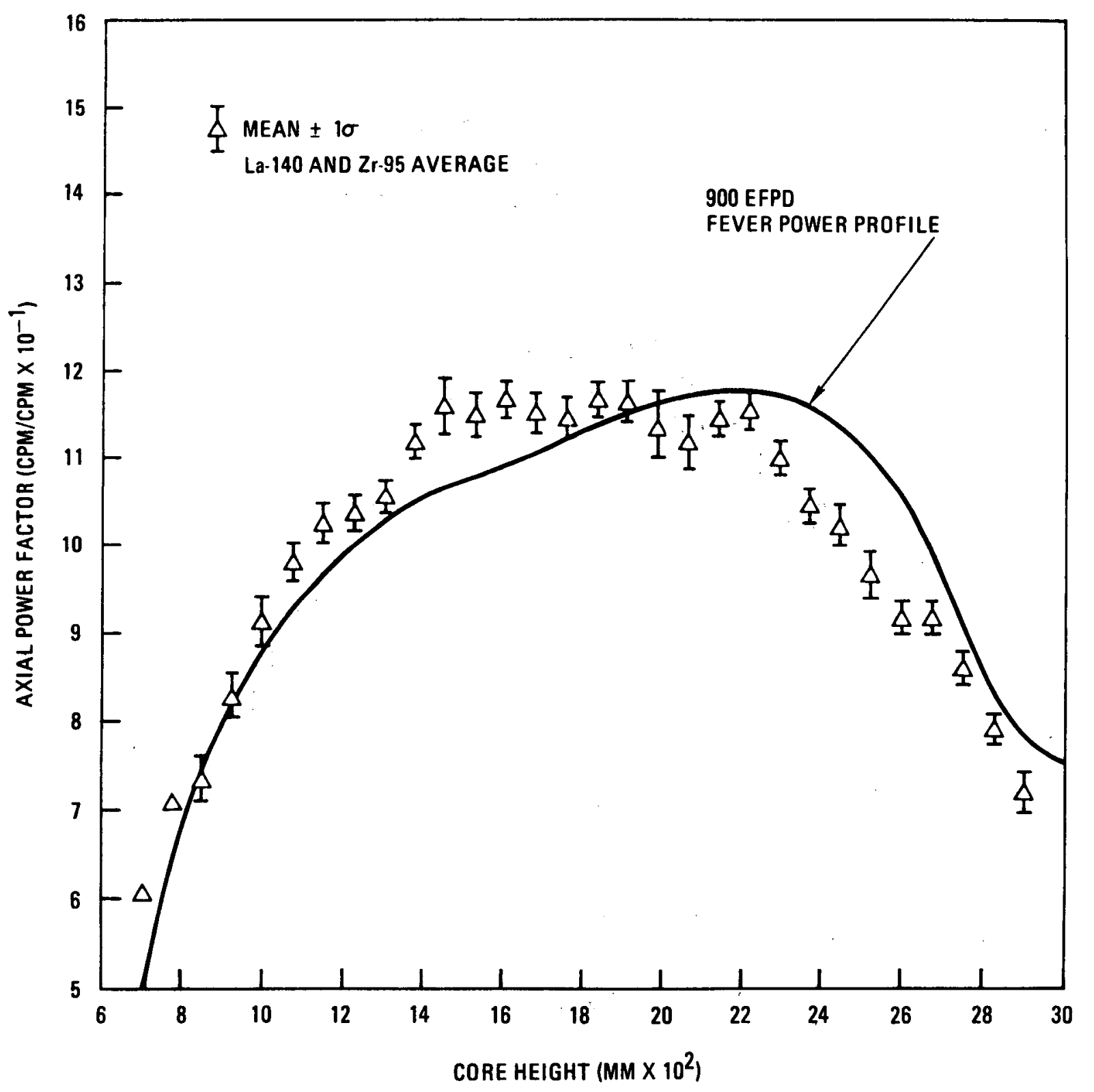

Fig. 14. FEVER calculated EOL power profile comparison for E14-01 


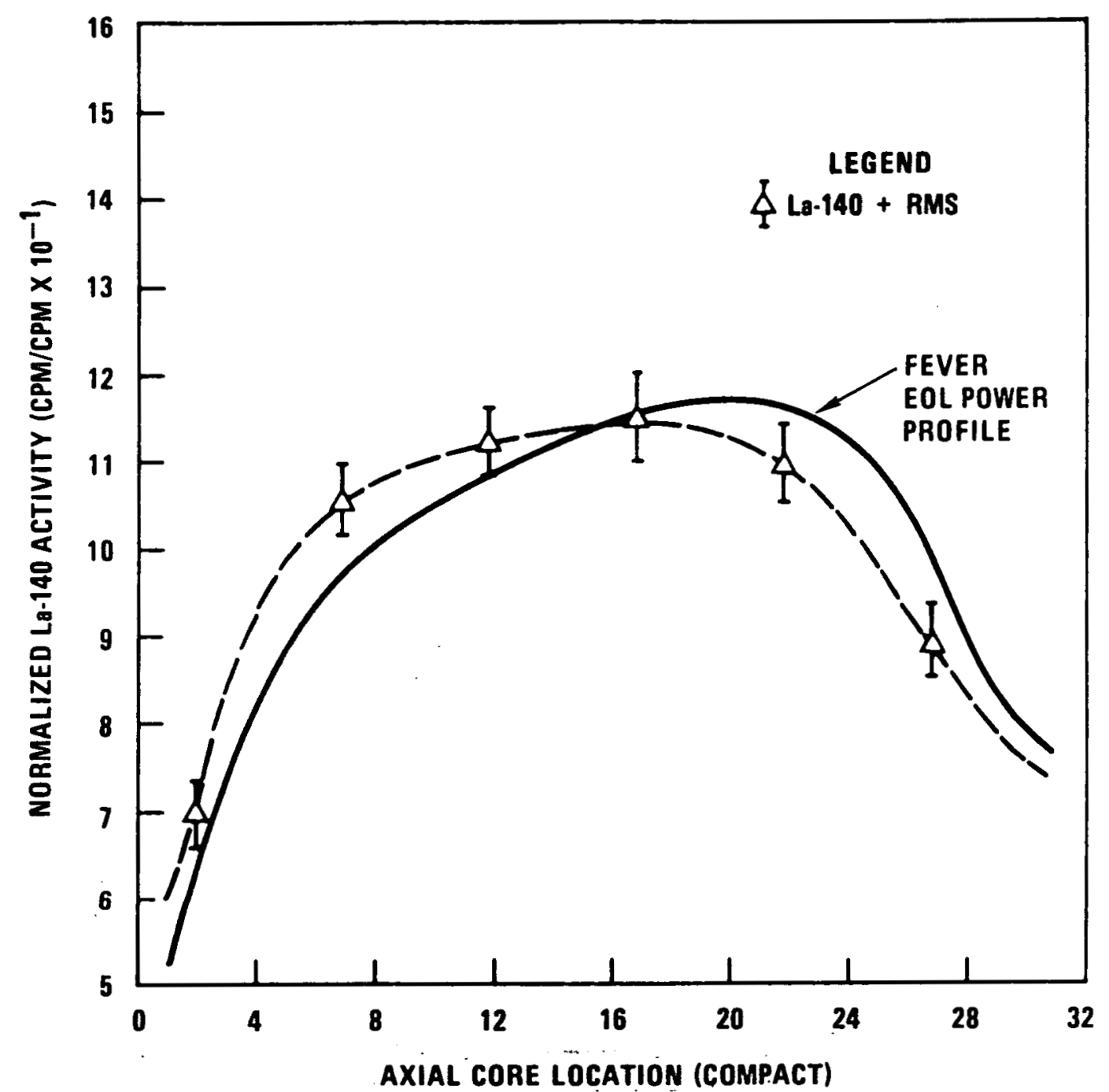

Fig. 15. EOL axial power profile comparison for 14 Phase I unperturbed elements

$$
\text { A-19 }
$$




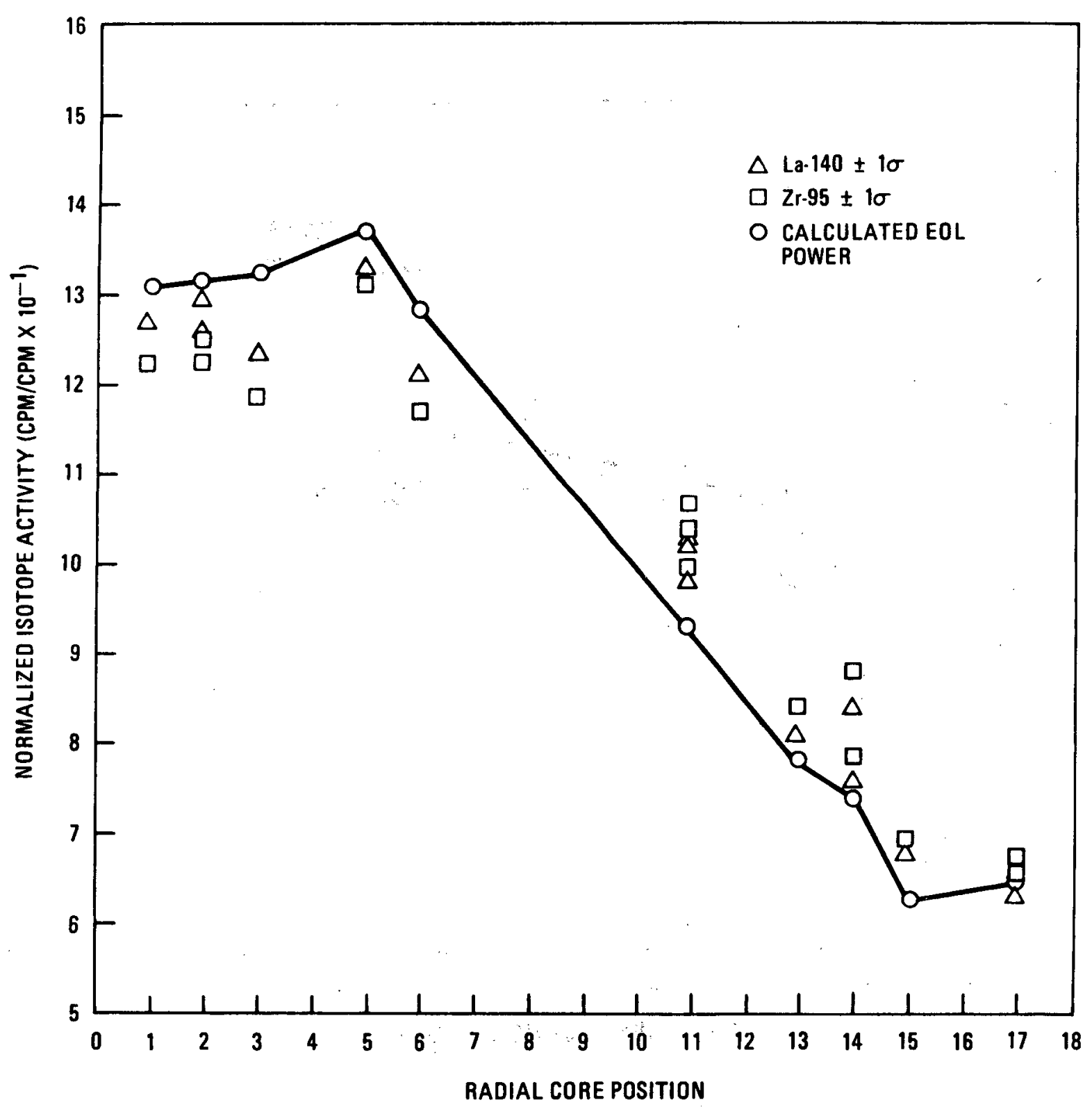

Fig. 16. Normalized radial distribution of La-140 and $\mathrm{Zr}-95$ in Phase I driver elements 


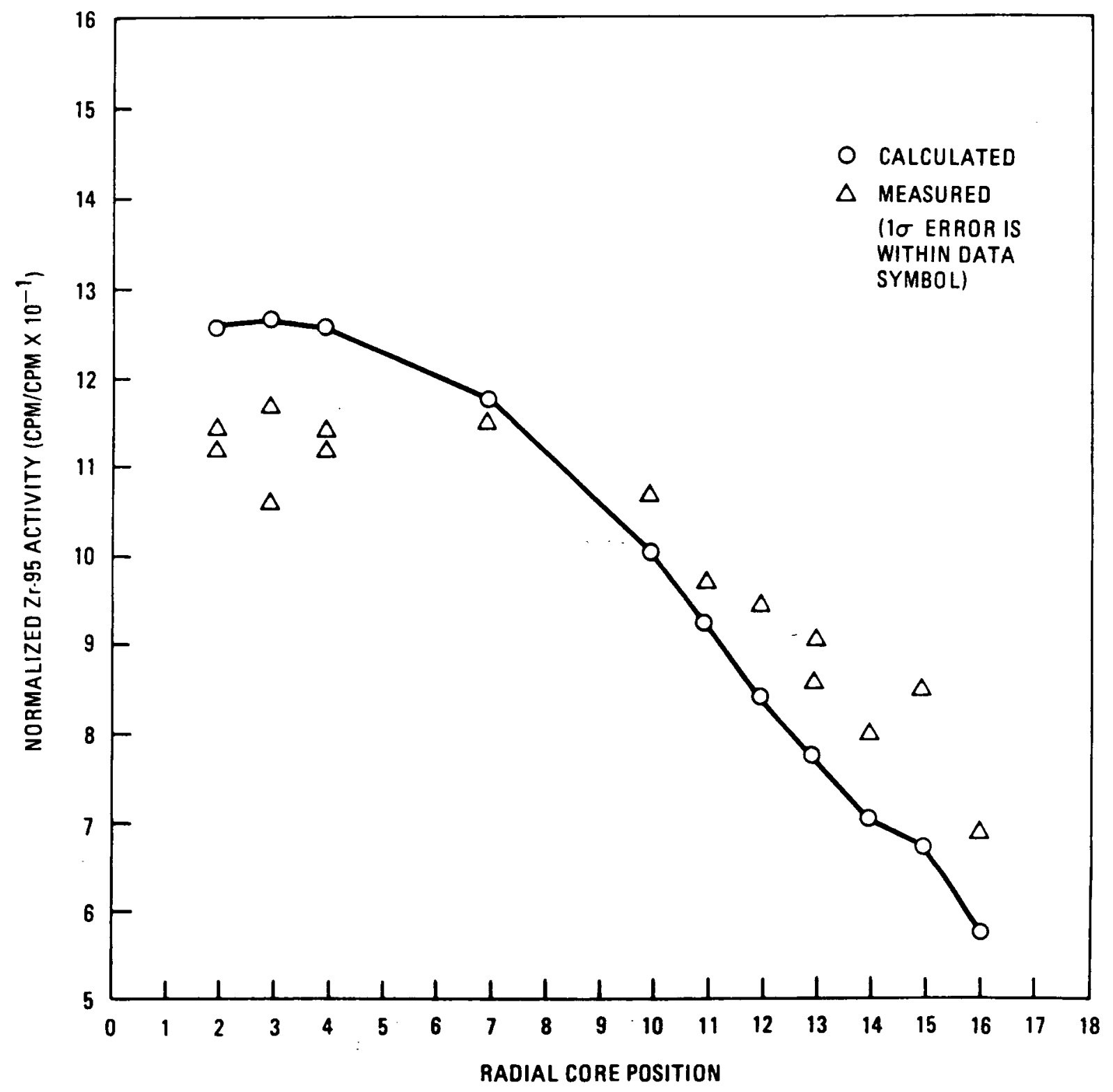

Fig. 17. Normalized radial distribution of $\mathrm{Zr}-95$ in Phase II driver elements 


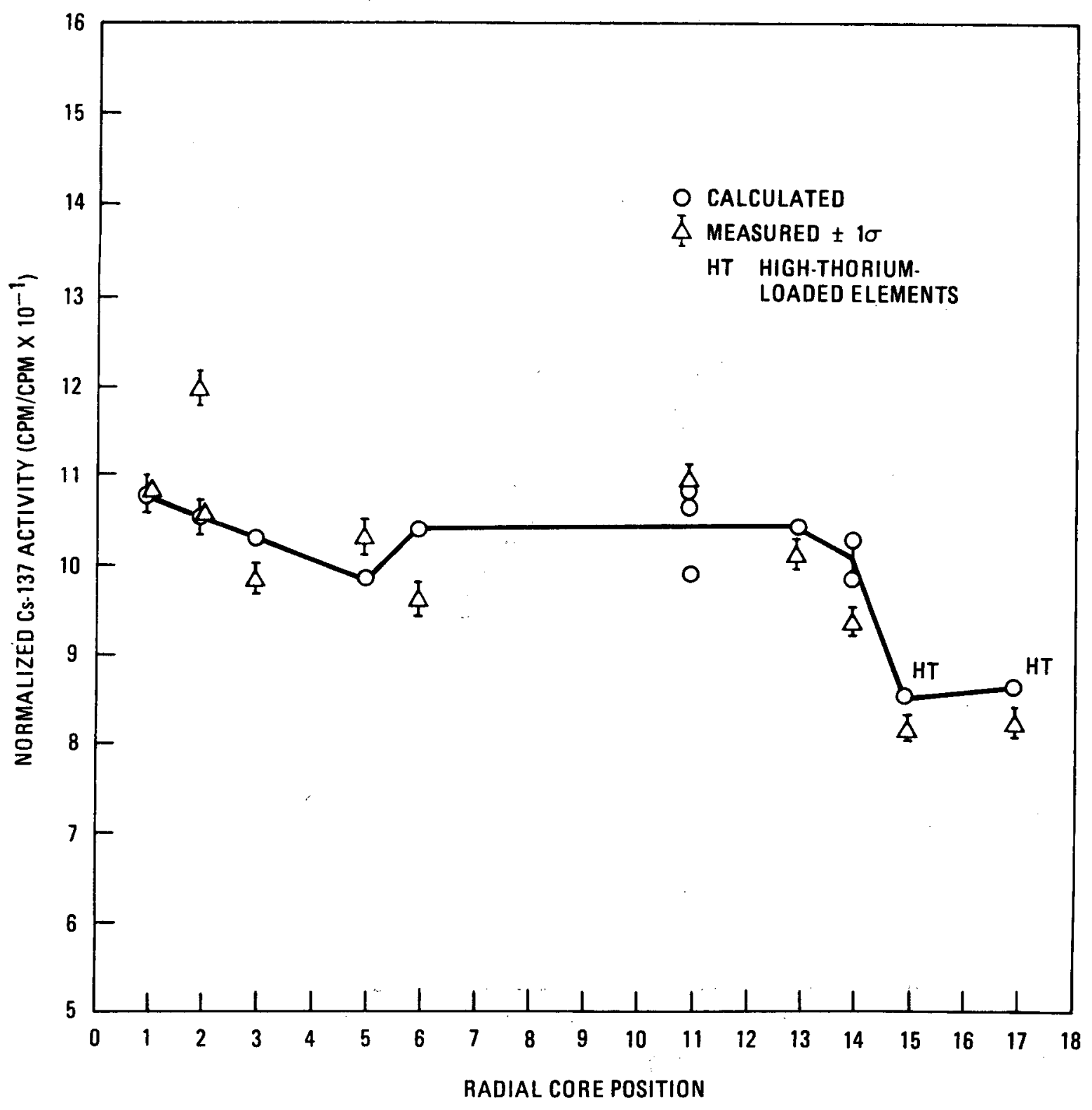

Fig. 18. Normalized radial distribution of $\mathrm{Cs}-137$ in Phase I driver elements 


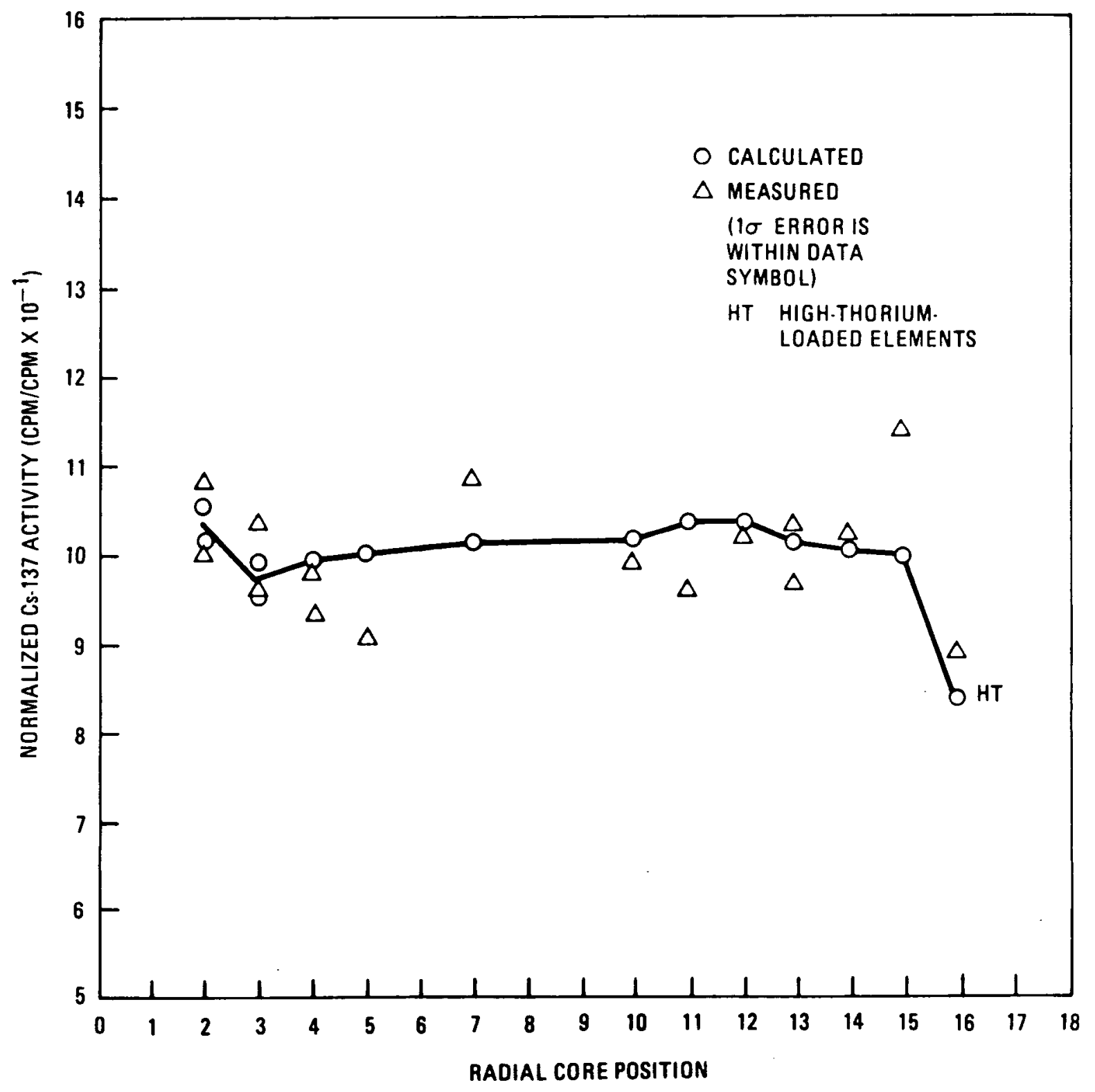
Fig. 19. Normalized radial distribution of Cs-137 in Phase II driver
elements 


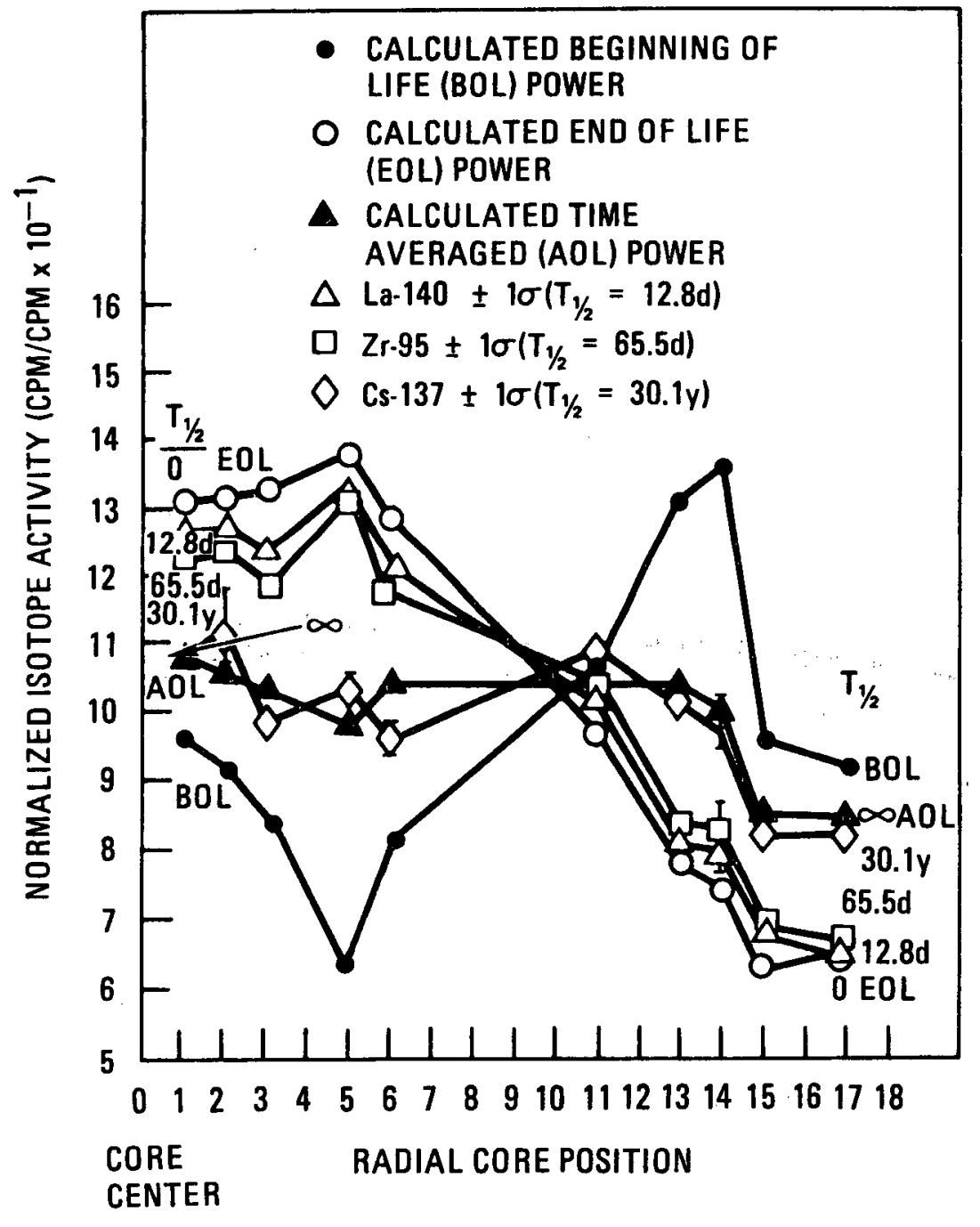

Fig. 20. Normalized radial isotope distribution summary for Phase I 


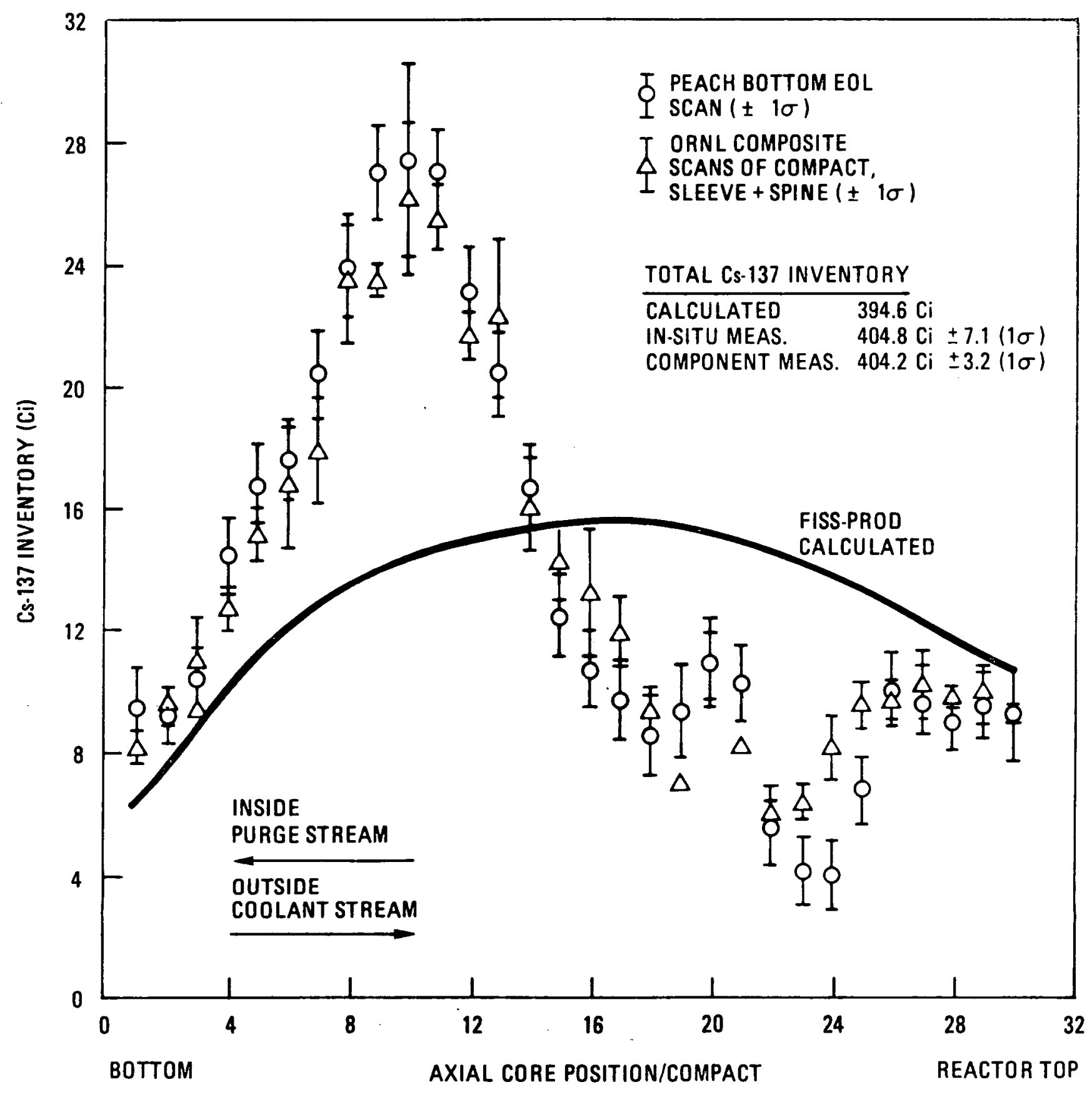

Fig. 21. Cs-137 inventory versus axial core position for F03-01 


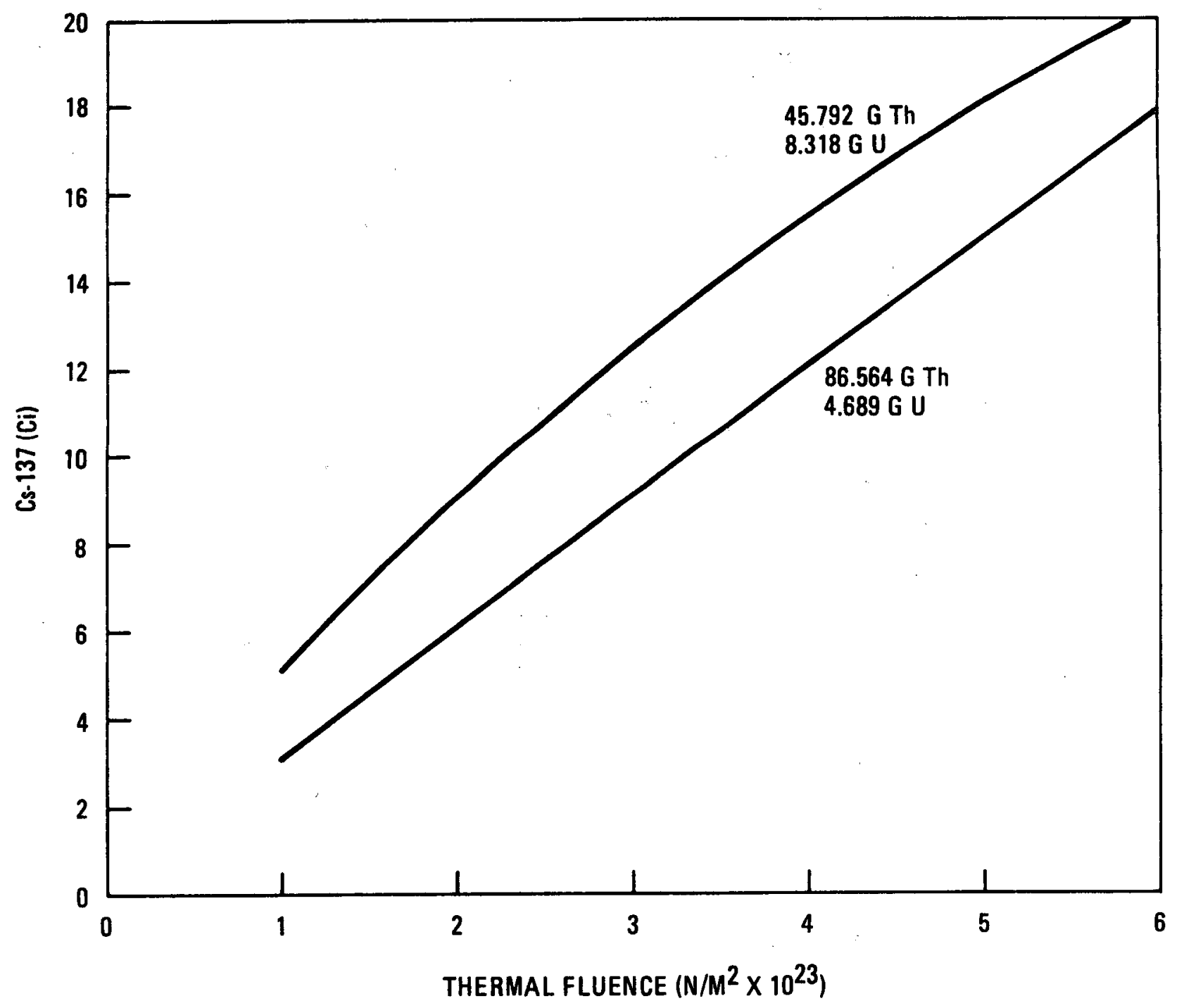

Fig. 22. FISS-PROD calculated Cs-137 inventories for Peach Bottom driver elements 


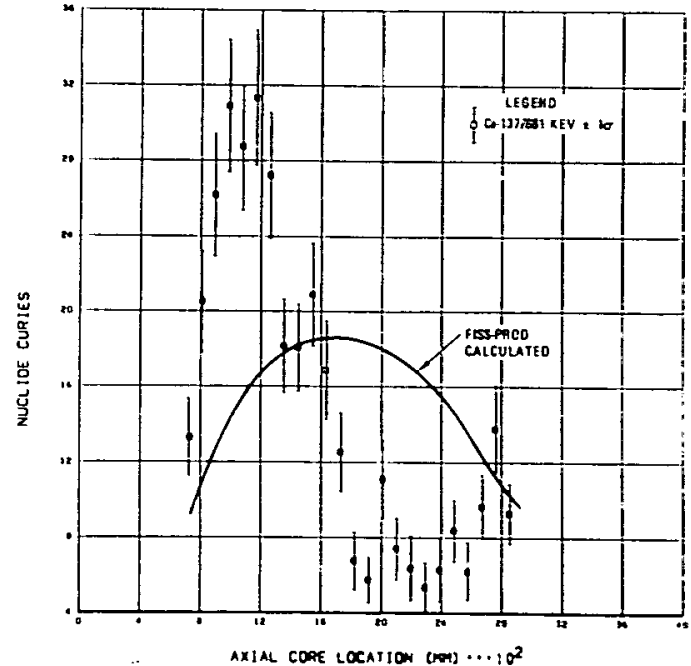

(a)

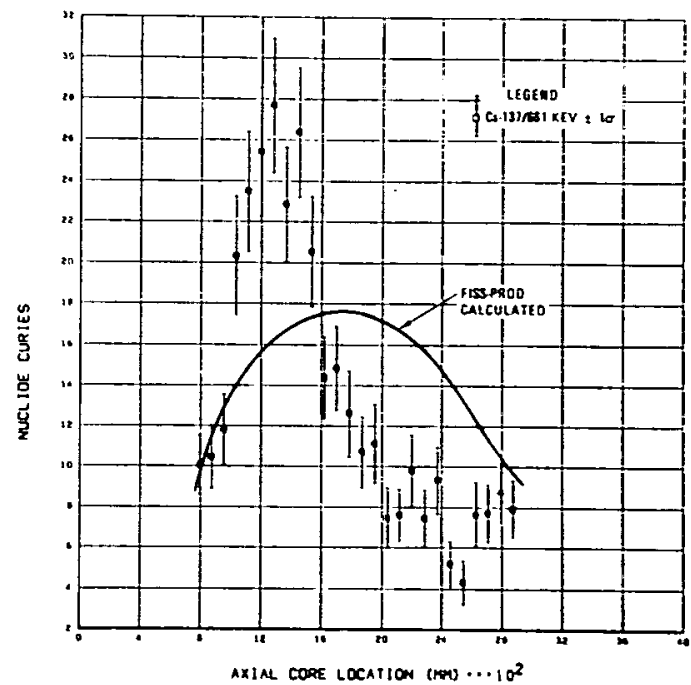

(c)

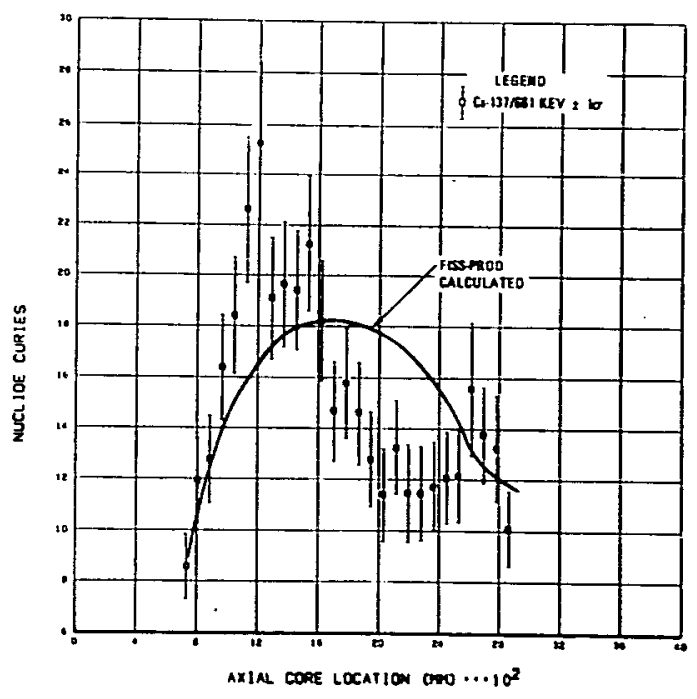

(e)

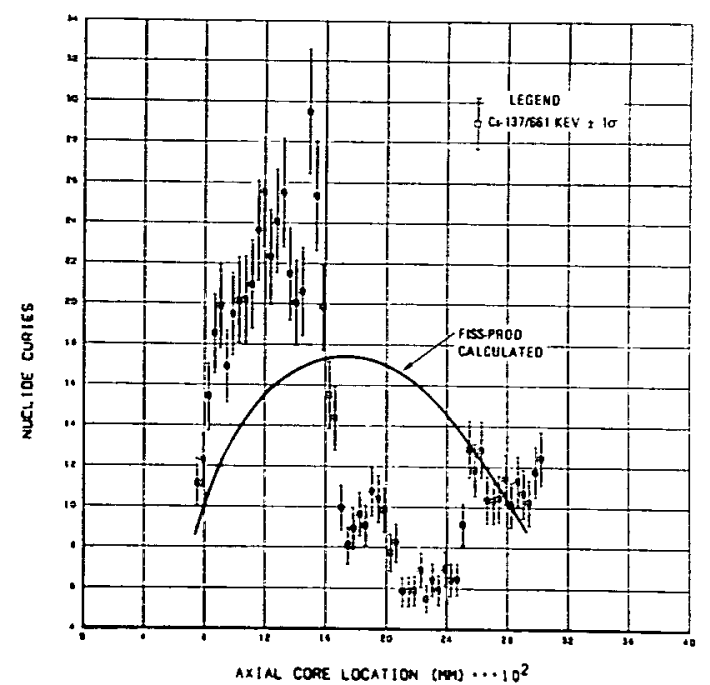

(b)

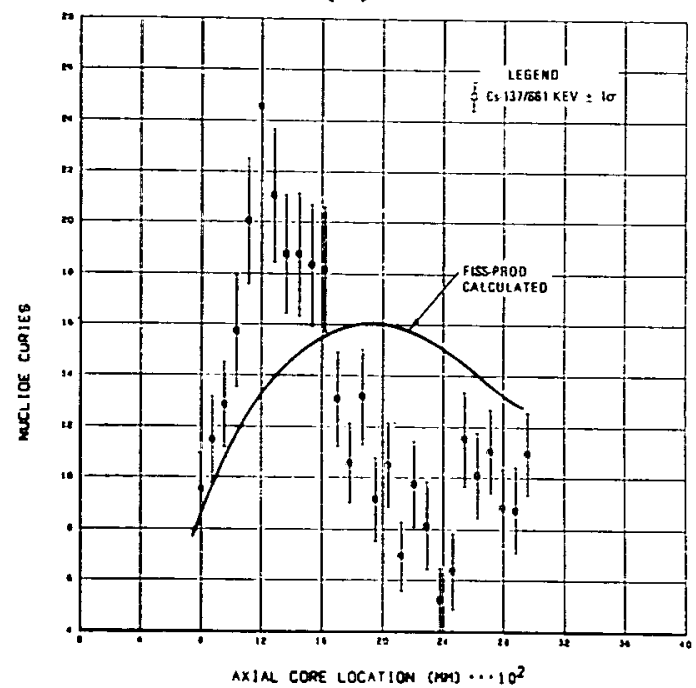

(d)

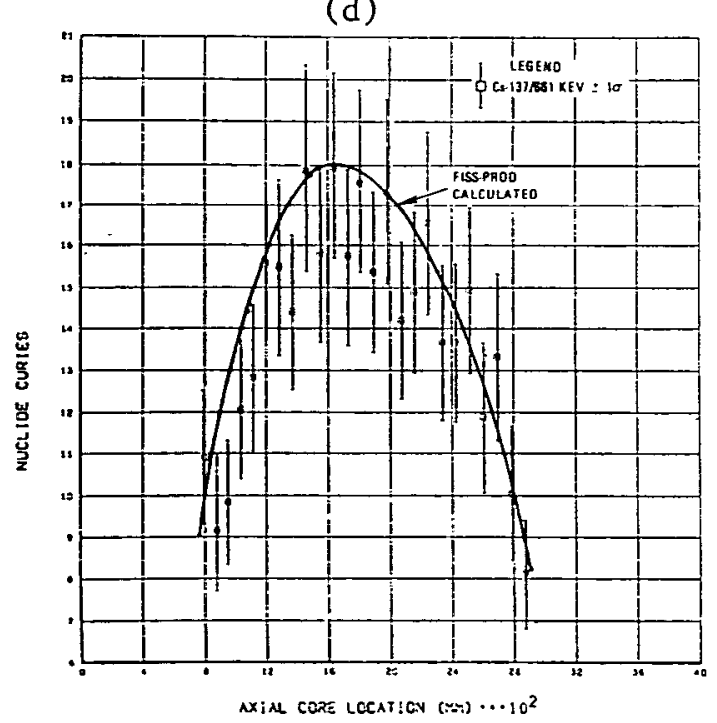

(f)

Fig. 23. Absolute cesium nuclide activities for (a) E01-01, (b) E03-02, (c) E06-02, (d) E09-01, (e) E11-01, and (f) E14-01 


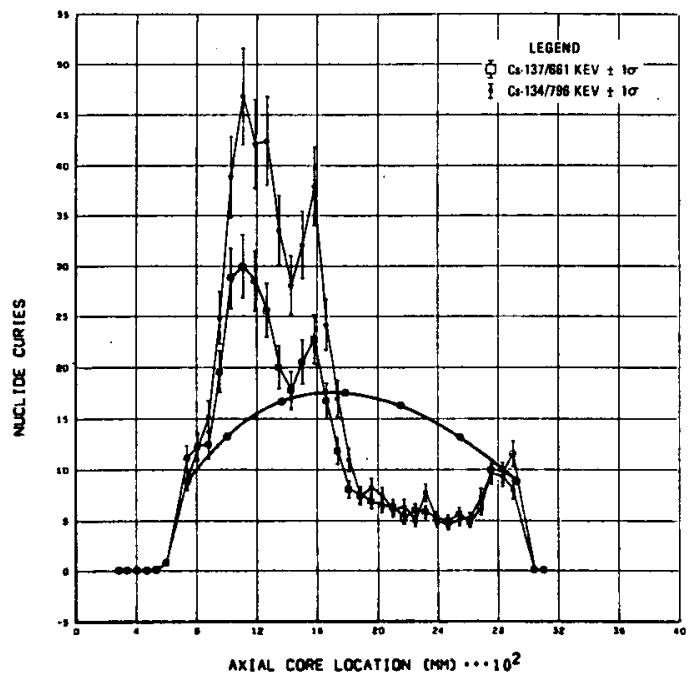

(a)

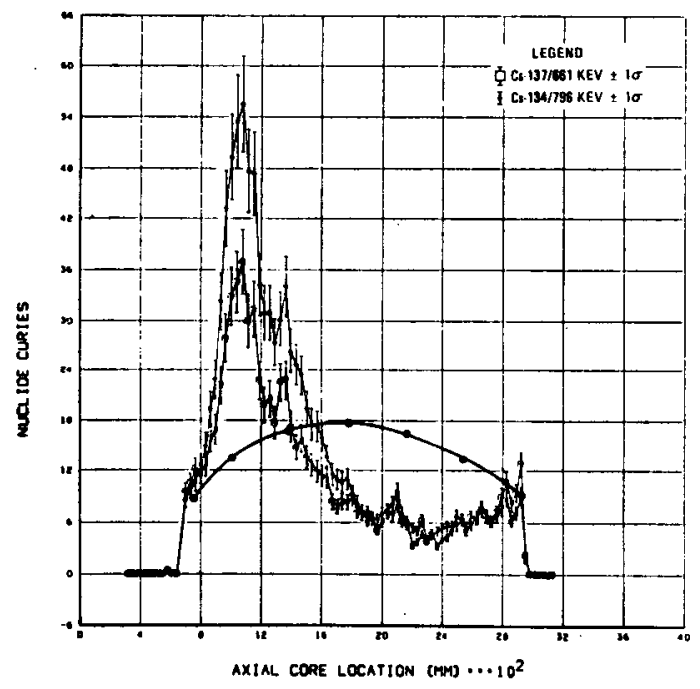

(b)

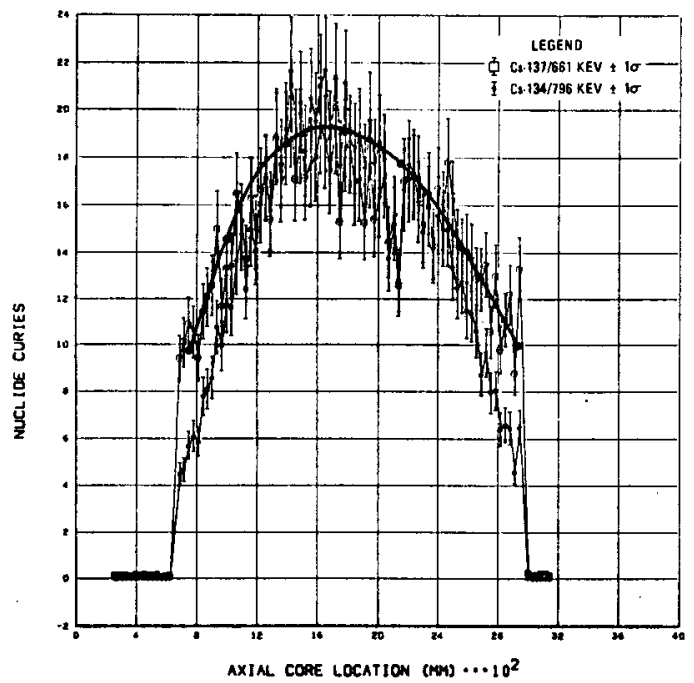

(c)

Fig. 24. Absolute cesium nuclide activities for (a) F02-01, (b) F04-03, and (c) F15-14. Solid curves are FISS-PROD calculations. 


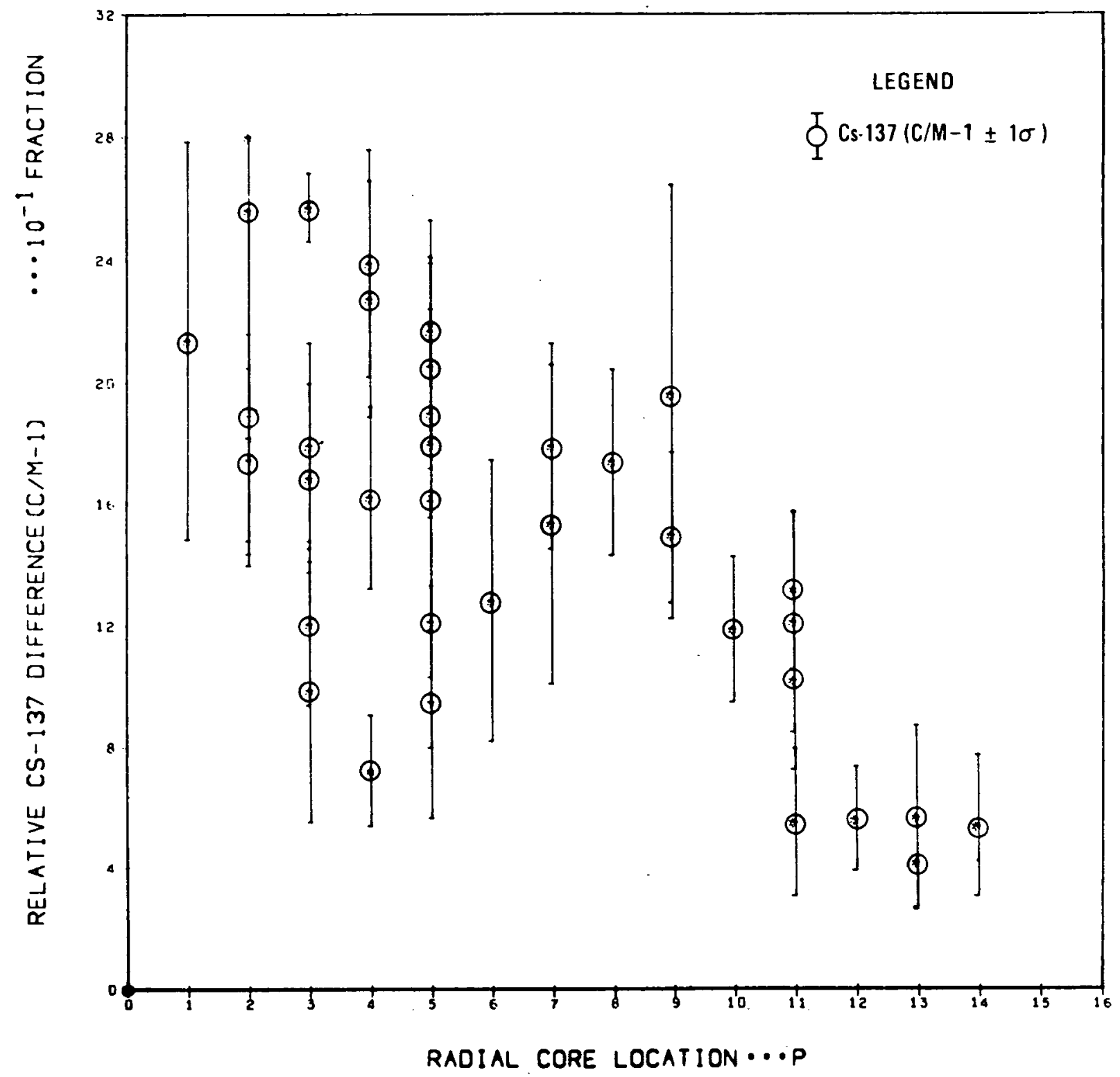

Fig. 25. Relative Cs -137 difference versus core location 


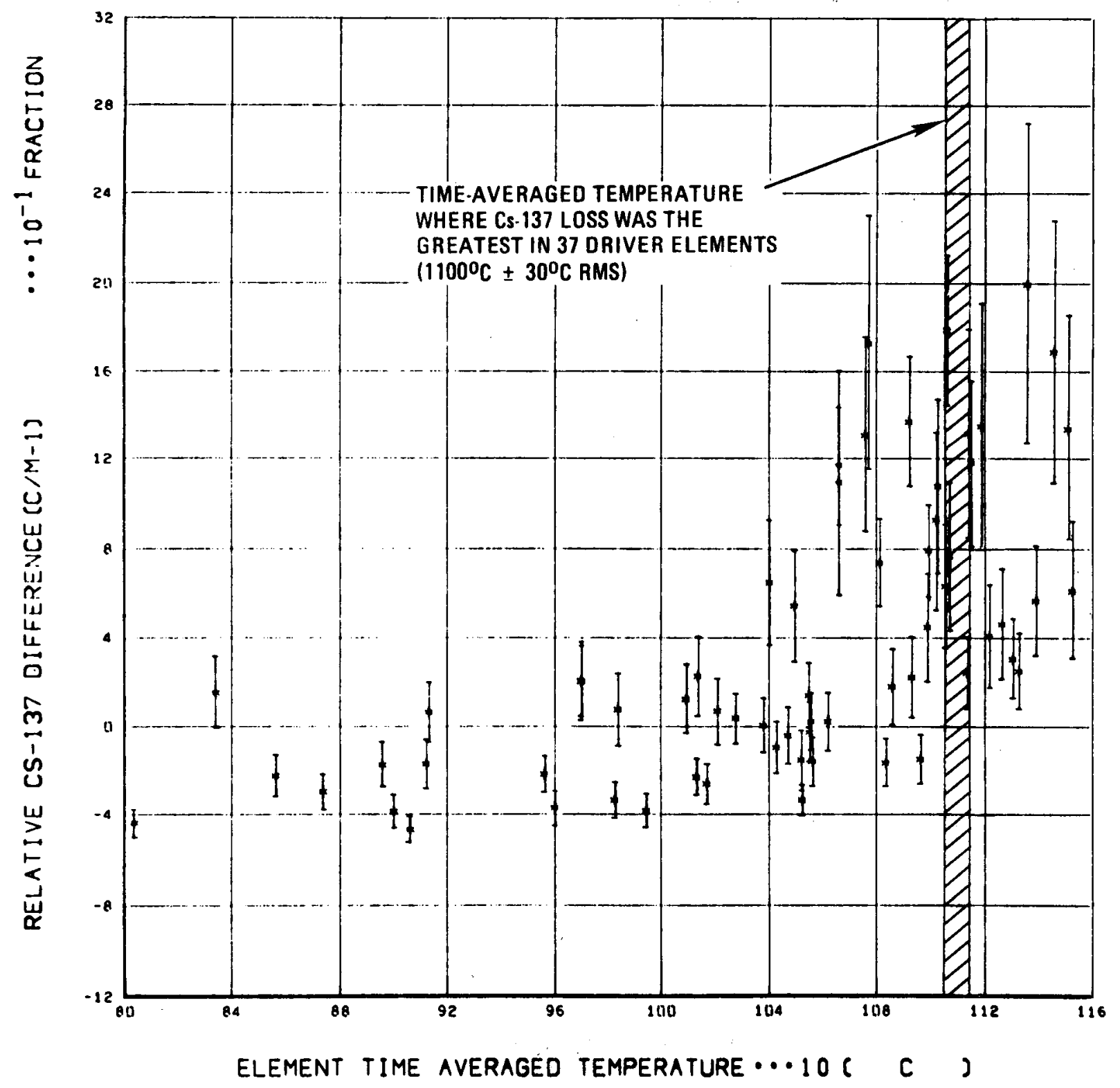

Fig. 26. Relative $\mathrm{Cs}-137$ difference versus mean element temperature 


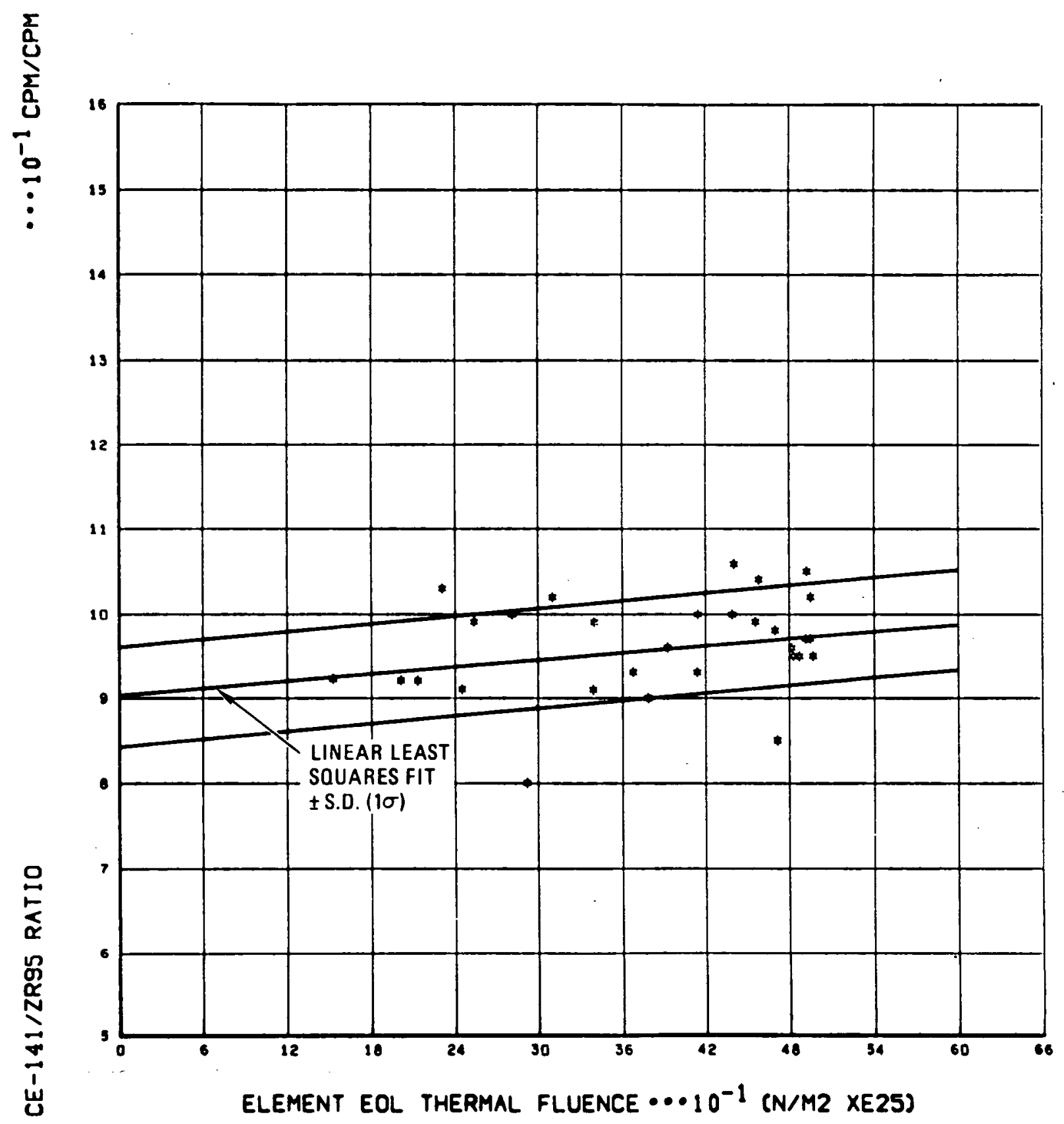

Fig. 27. Ce-141/Zr-95 CPM ratio versus thermal fluence

$$
\text { A-31 }
$$




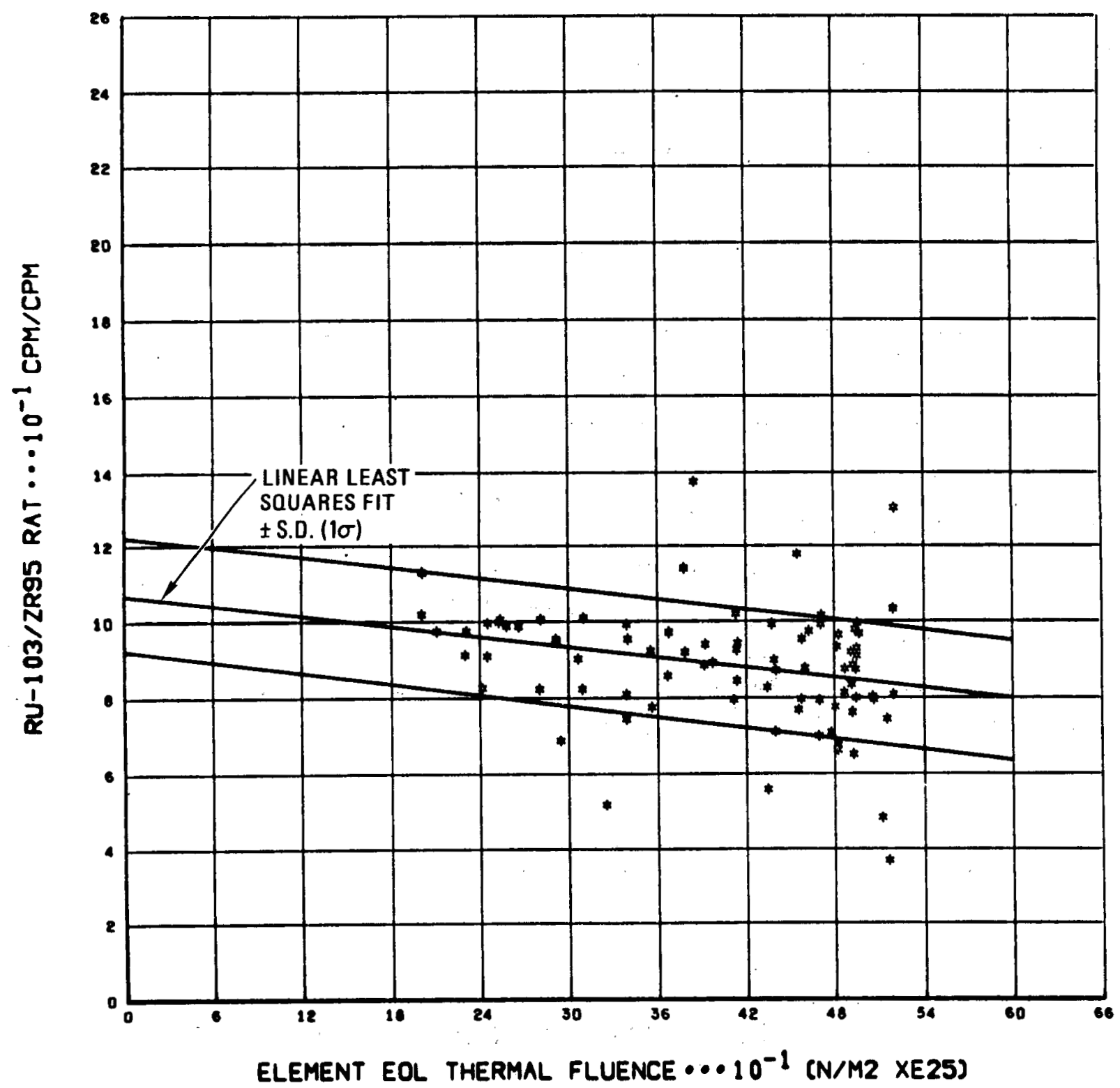

Fig. 28. Ru-103/Zr-95 CPM ratio versus thermal fluence 


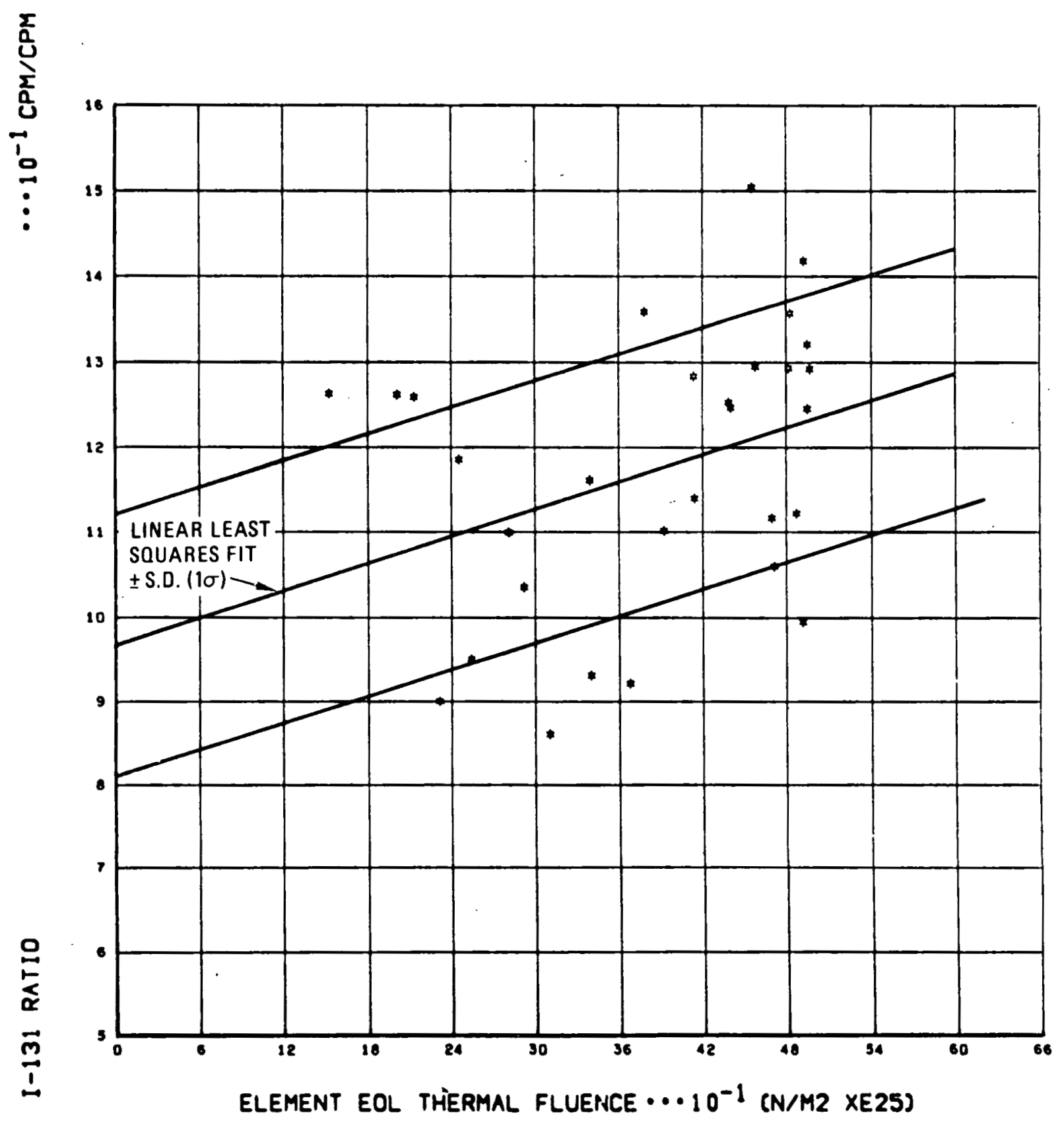

Fig. 29. I-131/2r-95 CPM ratio versus thermal fluence 


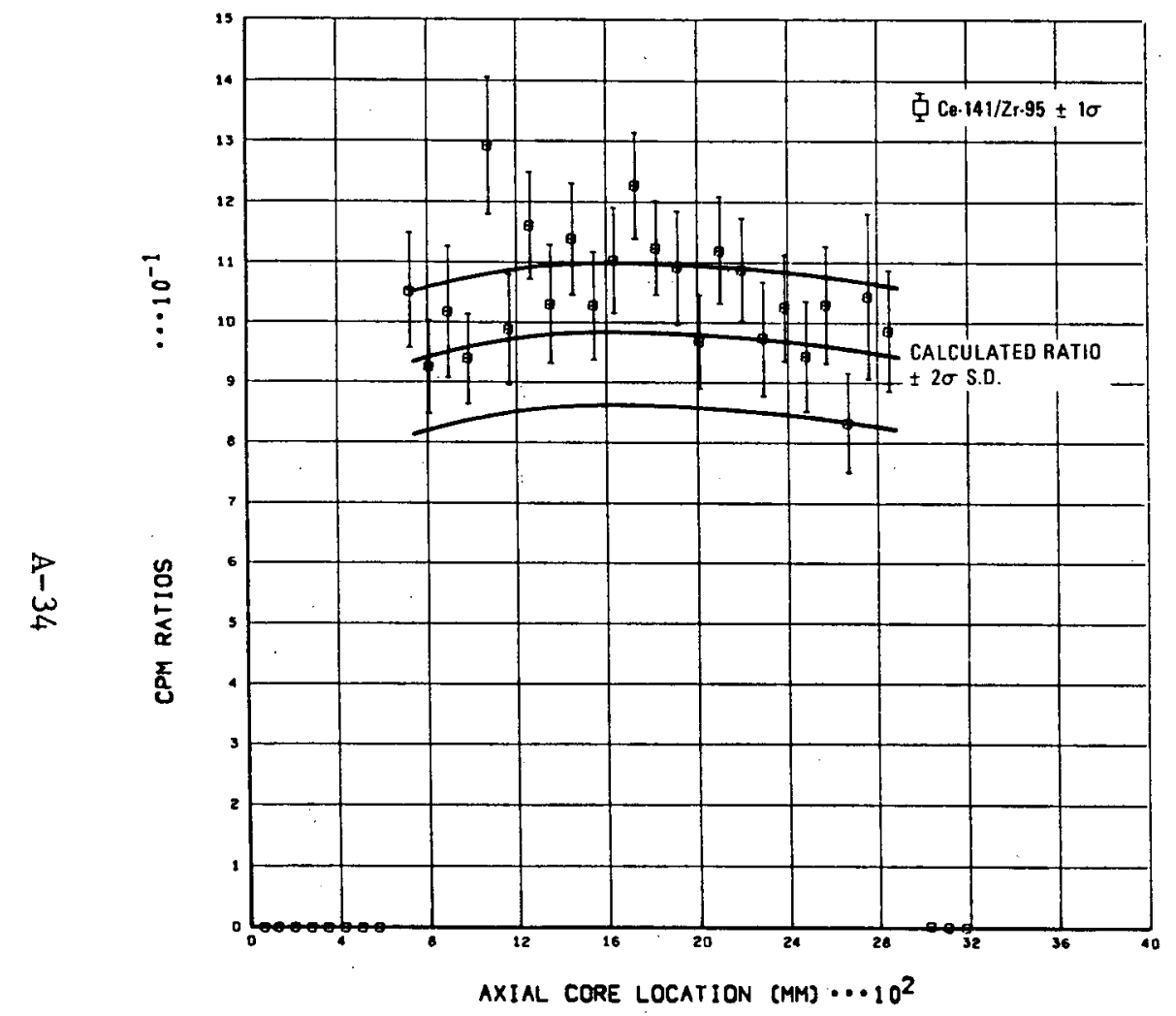

Fig. 30(a). Cerium/zirconium nuclide CPM ratios for E01-01

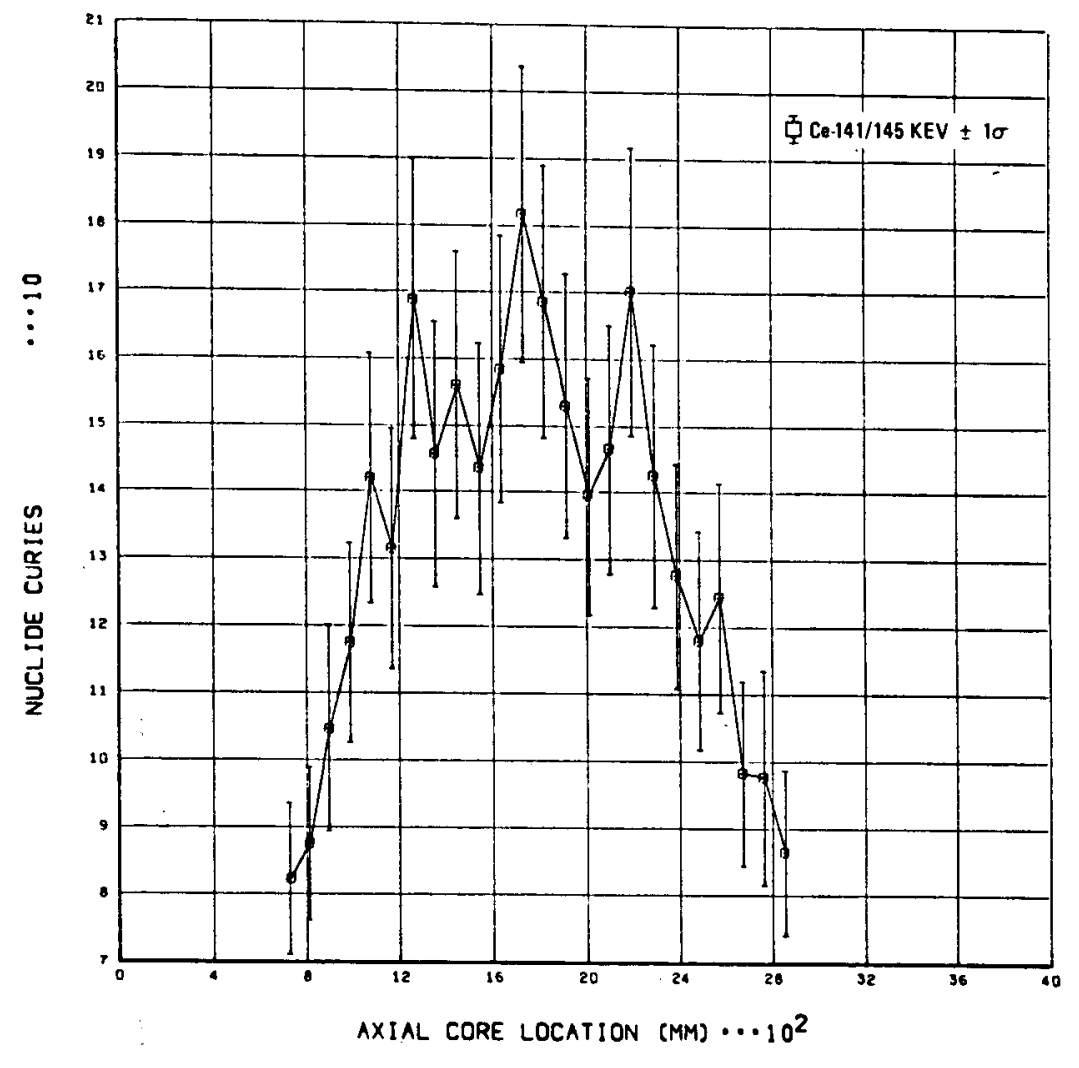

Fig. 30(b). Absolute cerium nuclide activities for E01-01 


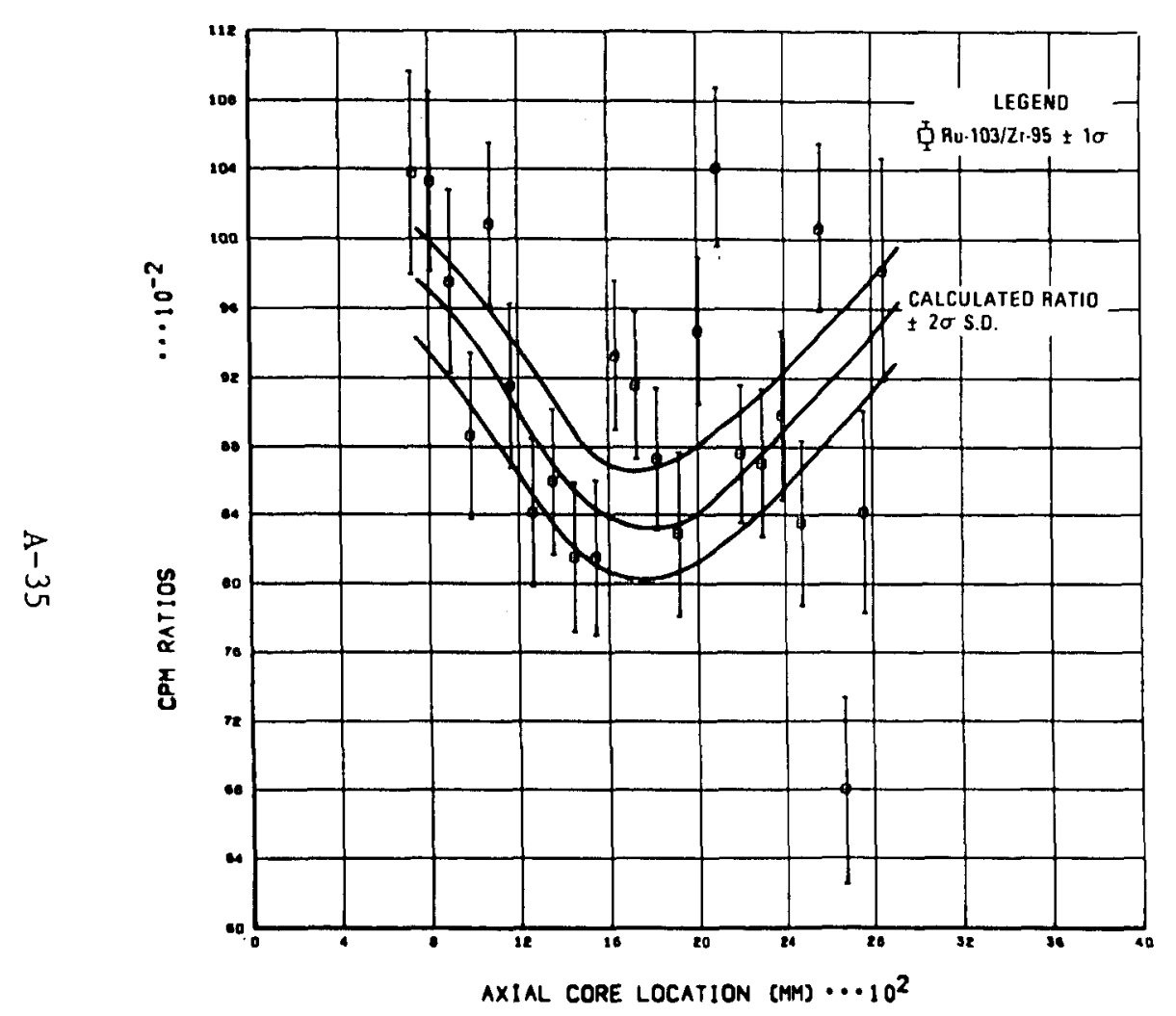

Fig. 31(a). Ruthenium/zirconium nuclide CPM ratios for E01-01

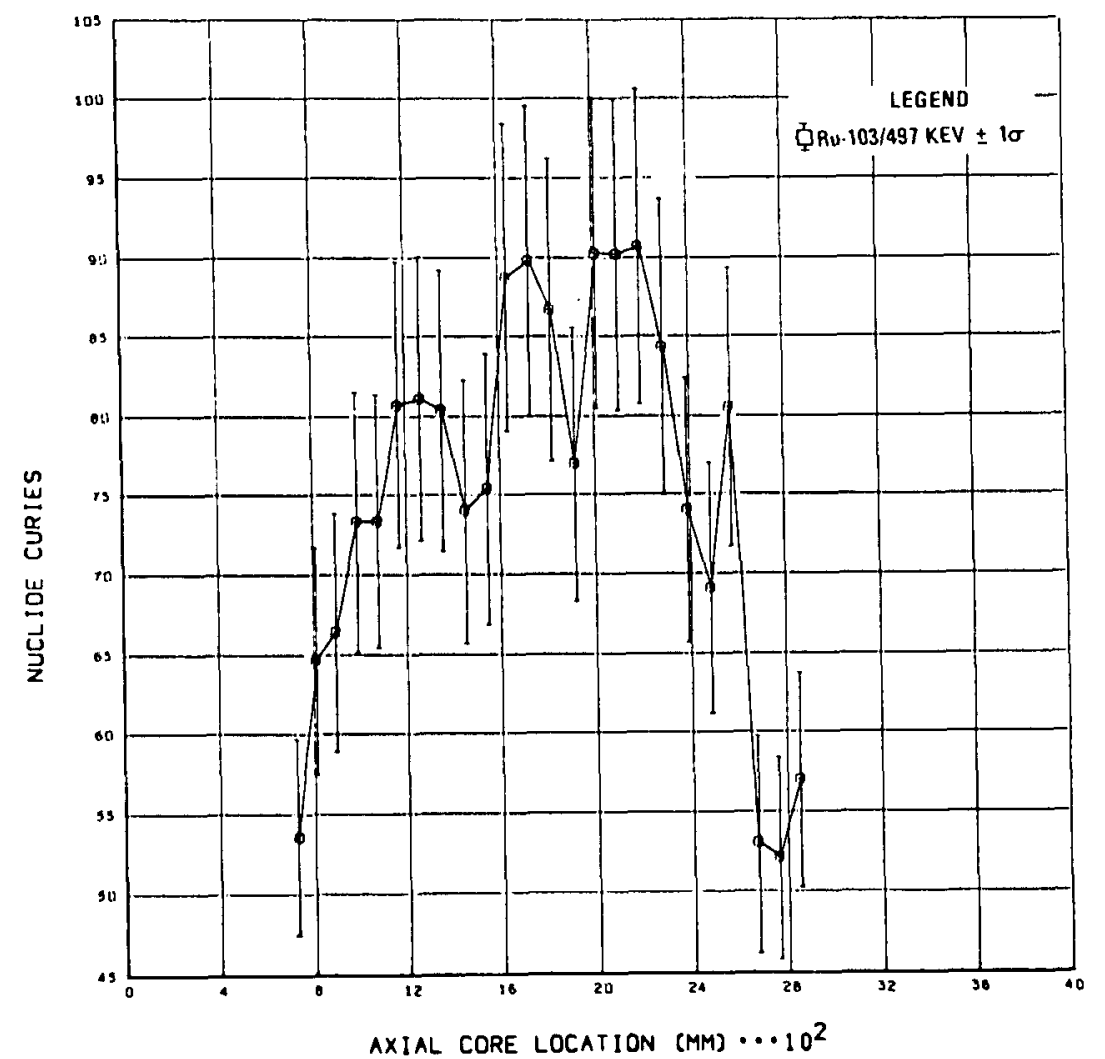

Fig. 31(b). Absolute ruthenfum nuclide activities for E01-01 


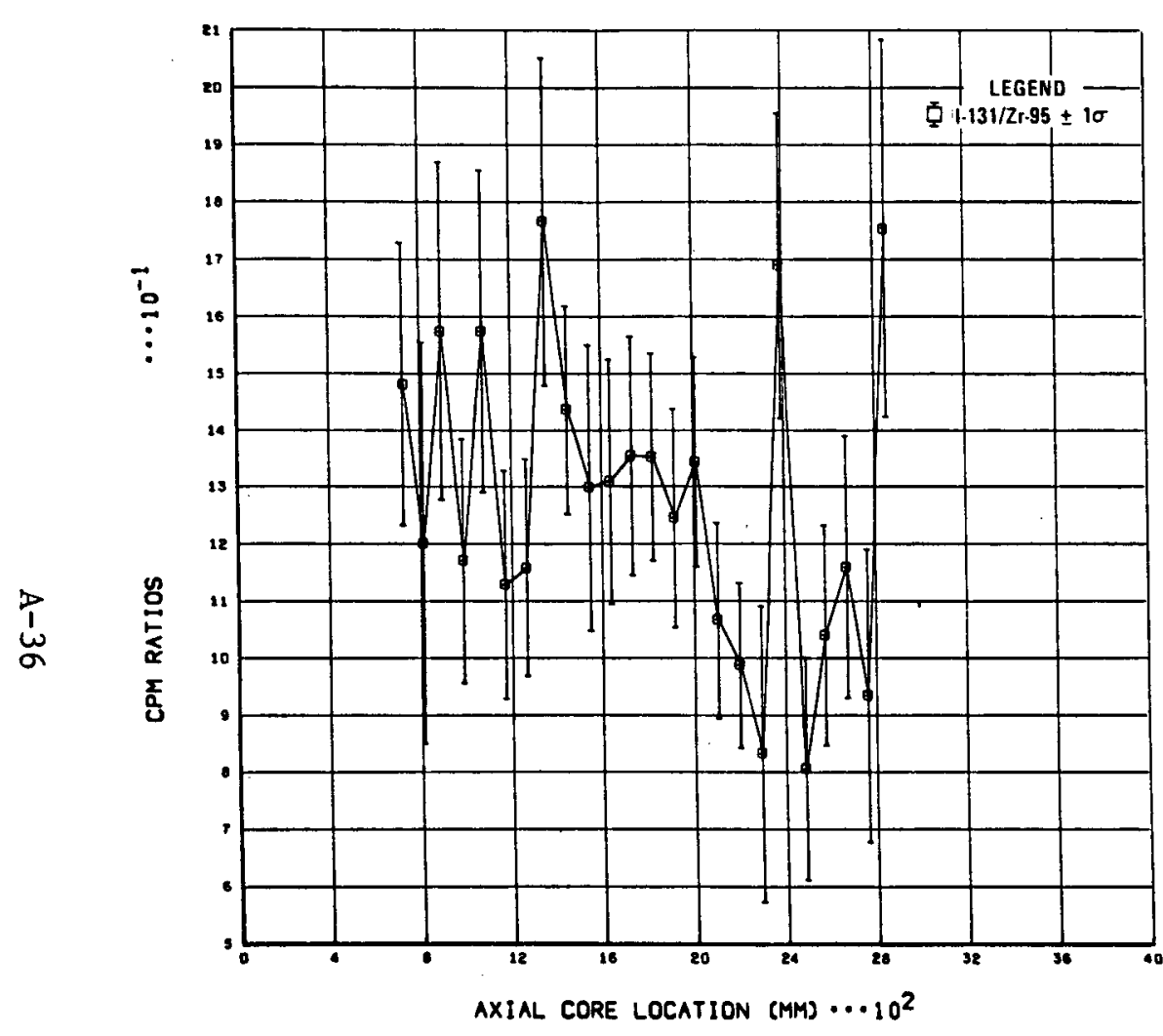

Fig. 32(a). Iodine/zirconium nuclide CPM ratios for E01-01

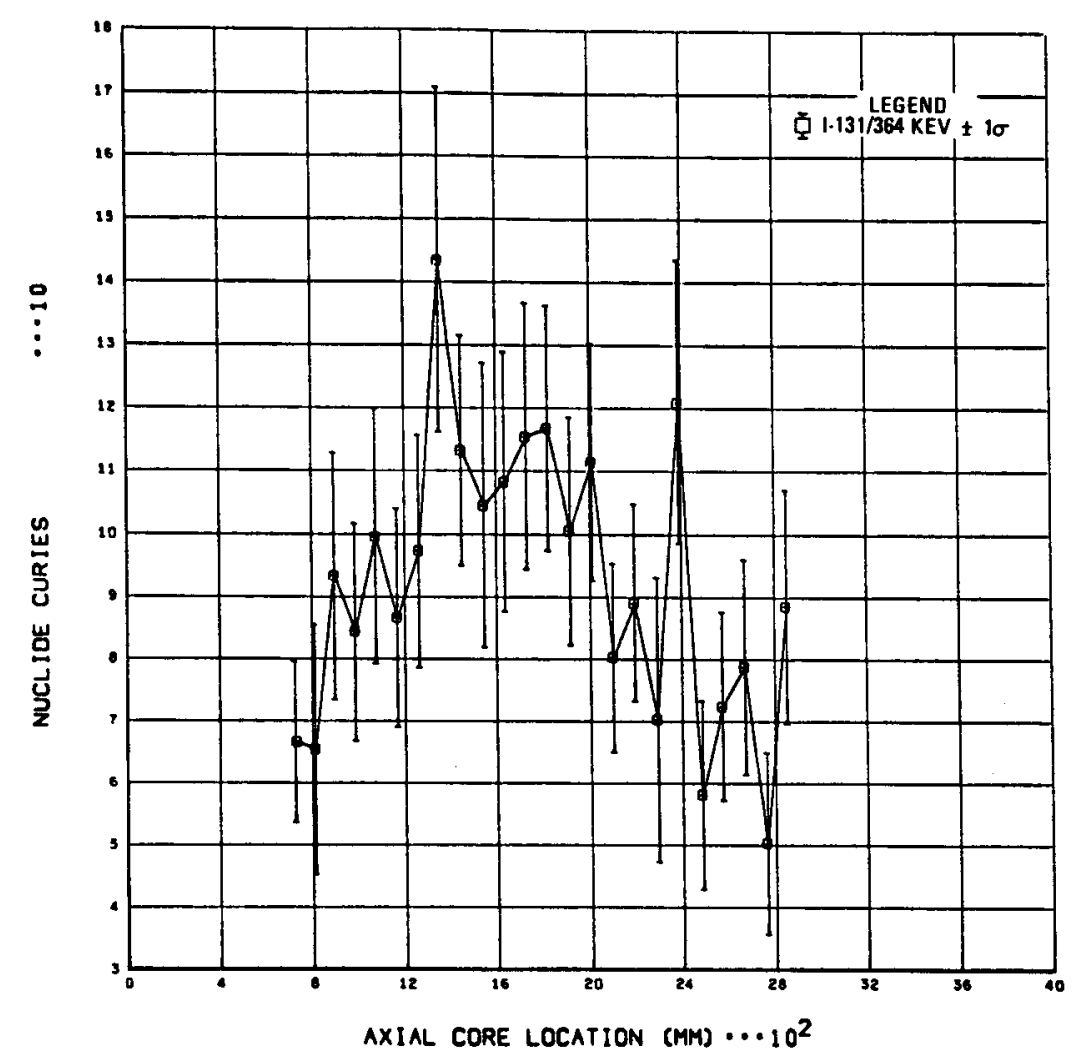

Fig. 32(b). Absolute iodine nuclide activities for E01-01 


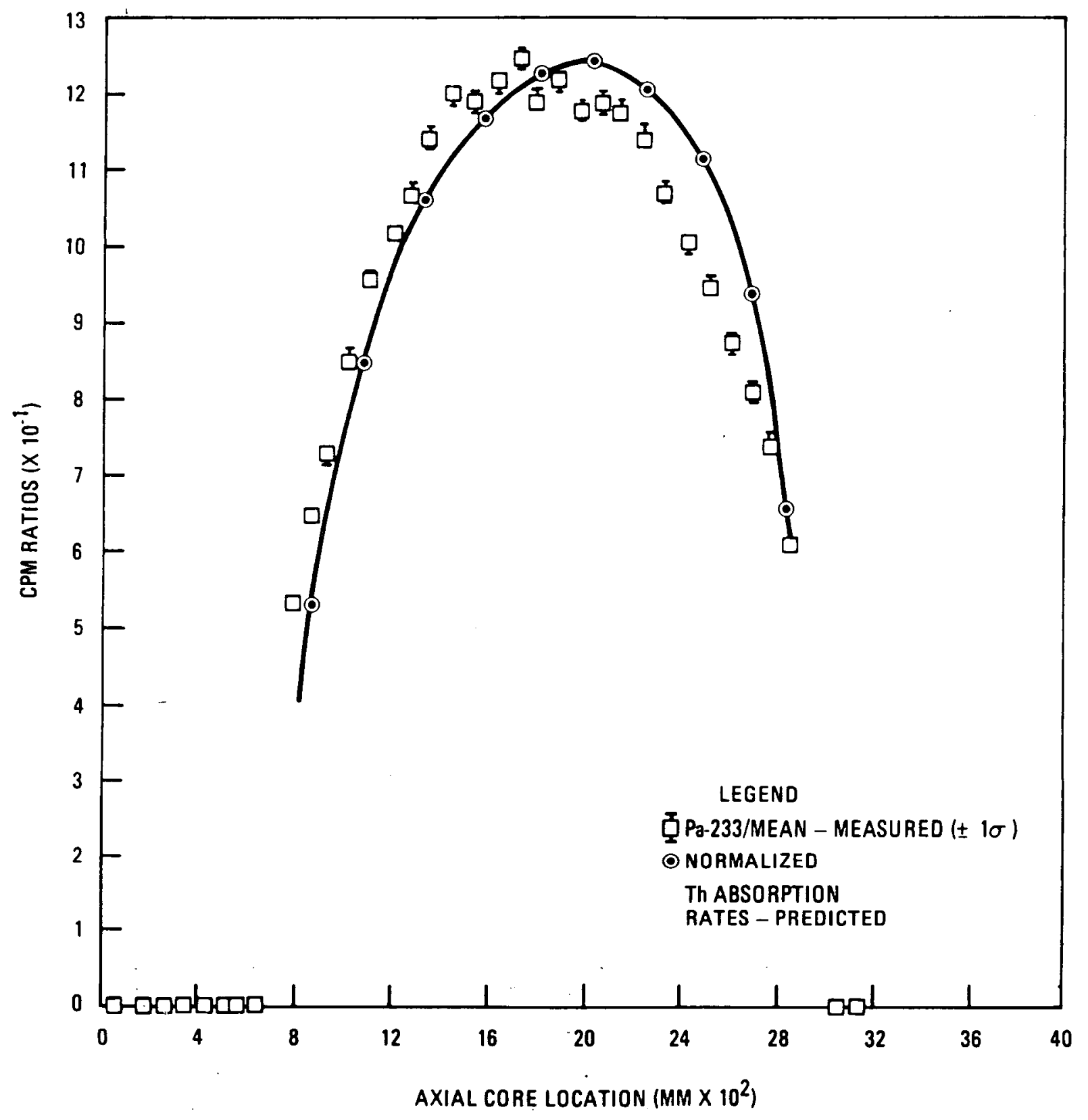

Fig. 33. Normalized protactinium CPM ratios for E14-01 


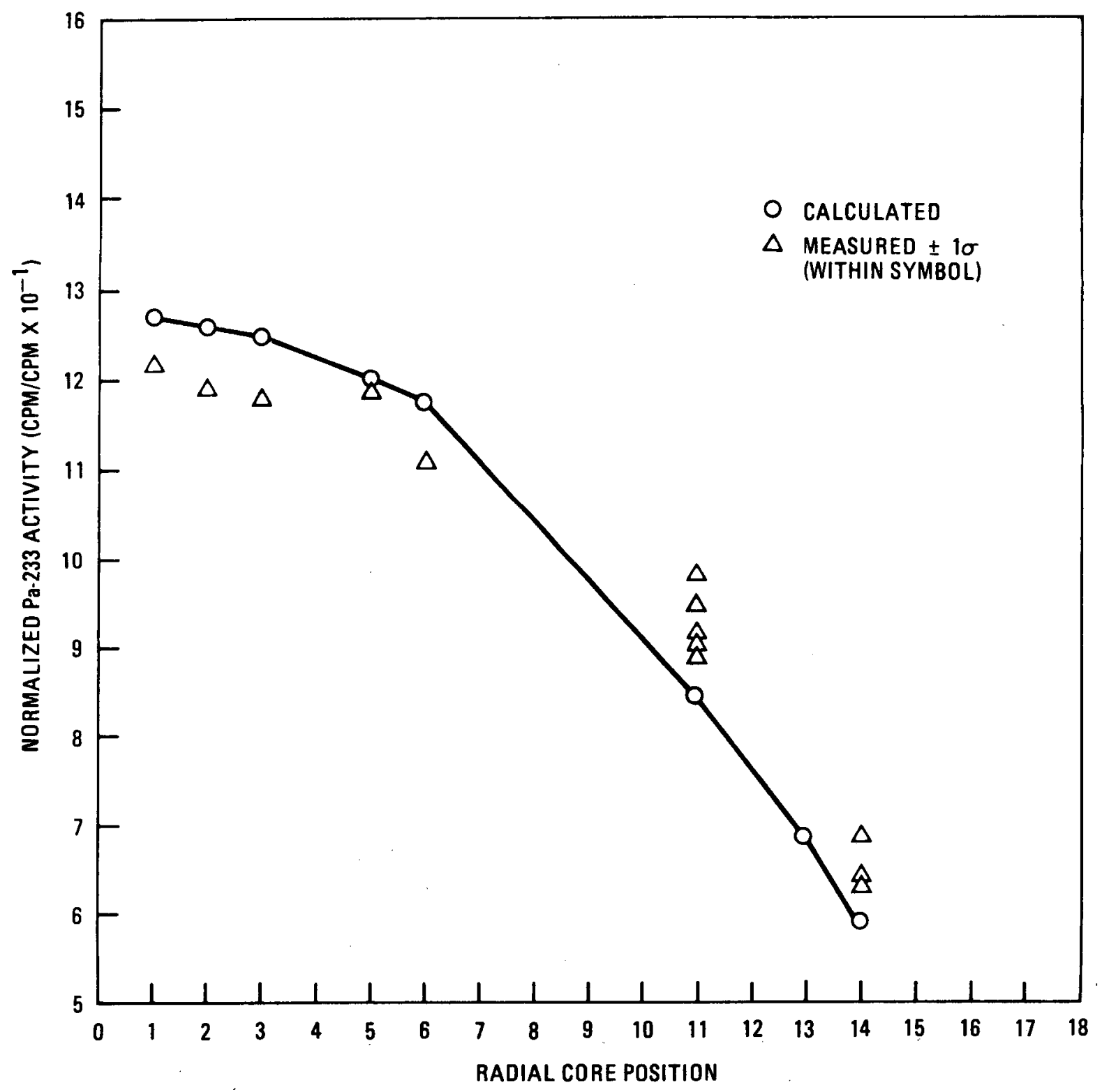

Fig. 34. Normalized radial distribution of Pa-233 in Phase I driver elements 


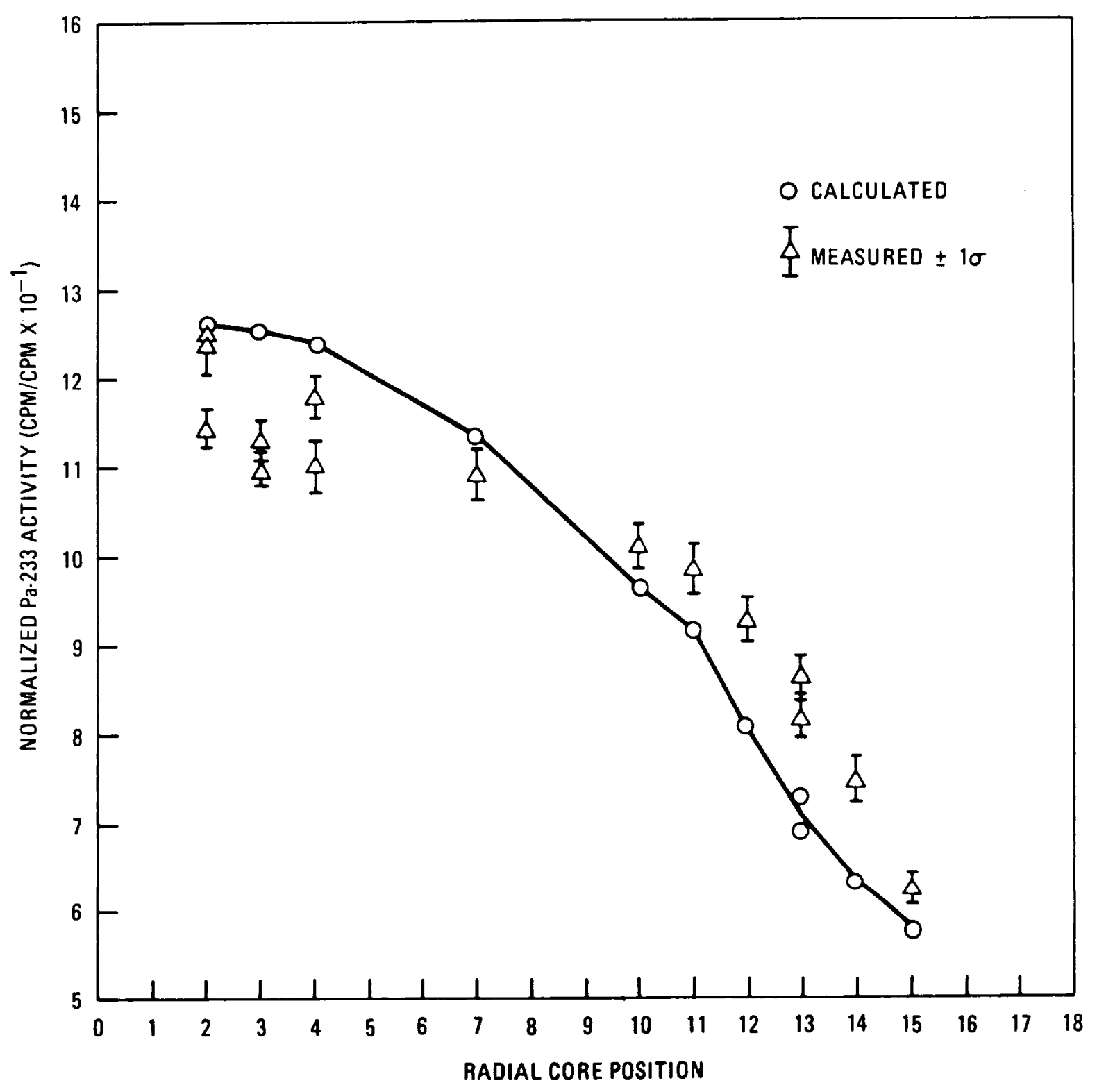

Fig. 35. Normalized radial distribution of Pa-233 in Phase II driver elements 
APPENDIX B

\section{TABLES}

$B-1$ 
1 
TABLE 1

PEACH BOTTOM ELEMENTS GAMMA SCANNED DURING PHASE I

\begin{tabular}{|c|c|c|c|c|c|c|}
\hline \multirow{2}{*}{$\begin{array}{l}\text { Element } \\
\text { I.D. }\end{array}$} & \multirow{2}{*}{$\begin{array}{l}\text { Element } \\
\text { Type }\end{array}$} & \multirow{2}{*}{$\begin{array}{l}\text { Date } \\
\text { Scanned }\end{array}$} & \multirow{2}{*}{$\underset{(\mathrm{mm})}{\operatorname{Collimator}}(\mathrm{b})$} & \multirow{2}{*}{$\begin{array}{c}\text { Scans } \\
\text { (GA Tag No. 15) }\end{array}$} & \multicolumn{2}{|c|}{ UNIVAC Tape Storage } \\
\hline & & & & & Tape No. & File No. \\
\hline A $17-11$ & $\mathrm{D}$ & $11 / 24 / 74$ & $17.475 \times 0.254$ & $1-105$ & 2530 & 1 \\
\hline E14-01 & ID & $11 / 24 / 74$ & 1 & $106-191$ & & 2 \\
\hline $\mathrm{C} 02-01$ & FTE-6 & $11 / 25 / 74$ & & $192-267$ & & 3 \\
\hline E01-01 & ID & $11 / 26 / 74$ & & $268-343$ & & 4 \\
\hline E02-02 & ID & $11 / 27 / 74$ & & $344-386$ & & 5 \\
\hline E06-01 & FTE -18 & $11 / 27 / 74$ & & $387-468$ & & 6 \\
\hline E09-01 & ID & $11 / 29 / 74$ & & $469-515$ & & 7 \\
\hline E11-01 & ID & $11 / 29 / 74$ & & $516-574$ & & 8 \\
\hline E!5-01 & ID & $11 / 29 / 74$ & & $575-621$ & & 9 \\
\hline D 14-08 & FTE-8 & $11 / 30 / 74$ & & $622-668$ & & 10 \\
\hline E $10-01$ & FTE -13 & $11 / 30 / 74$ & & $669-717$ & & 11 \\
\hline E07-01 & ID & $11 / 30 / 74$ & & $718-764$ & & 12 \\
\hline E06-02 & $D$ & $12 / 1 / 74$ & & $765-811$ & & 13 \\
\hline E05-01 & ID & $12 / 1 / 74$ & & $812-859$ & & 14 \\
\hline E15-02 & $\mathrm{D}$ & $12 / 2 / 74$ & & $860-907$ & & 15 \\
\hline D 10-06 & RTE-6 & $12 / 2 / 74$ & & $908-957$ & & 16 \\
\hline B $13-01$ & ID & $12 / 2 / 74$ & & $958-1010$ & & 17 \\
\hline$A 03-03$ & $\mathrm{D}$ & $12 / 2 / 74$ & & $1011-1056$ & & 18 \\
\hline D06-01 & ETE-9 & $12 / 3 / 74$ & & $1057-1102$ & & 19 \\
\hline $\mathrm{B} 02-02$ & ID & $12 / 3 / 74$ & & $1103-1148$ & & 20 \\
\hline $\mathrm{E} 02-01$ & FTE- 10 & $12 / 3 / 74$ & & $1149-1195$ & & 21 \\
\hline C10-06 & RTE-5 & $12 / 3 / 74$ & & $1196-1257$ & & 22 \\
\hline E $11-02$ & $\mathrm{D}$ & $12 / 4 / 74$ & & $1258-1306$ & & 23 \\
\hline A05-05 & $\mathrm{D}$ & $12 / 4 / 74$ & & $1307-1353$ & & 24 \\
\hline C14-08 & FTE-5 & $12 / 5 / 74$ & & $1354-1407$ & & 25 \\
\hline $\mathrm{A} 02-01$ & FTE-17 & $12 / 5 / 74$ & & $1408-1462$ & & 26 \\
\hline B03-01 & $\mathrm{D}$ & $12 / 5 / 74$ & & $1463-1507$ & & 27 \\
\hline C05-04 & FBTE-1 & $12 / 5 / 74$ & & $1508-1555$ & & 28 \\
\hline B $14-02$ & $\mathrm{D}$ & $12 / 5 / 74$ & & $1556-1605$ & & 29 \\
\hline D09-04 & FBTE-5 & $12 / 6 / 74$ & & $1606-1652$ & & 30 \\
\hline F10-06 & RTE-8 & $12 / 6 / 74$ & & $1655-1707$ & & 31 \\
\hline A 11-11 & FBTE-2 & $12 / 7 / 74$ & & $1708-1759$ & & 32 \\
\hline B06-01 & FTE- 12 & $12 / 7 / 74$ & & $1760-1809$ & & 33 \\
\hline B14-08 & FBTE-3 & $12 / 7 / 74$ & & $1810-1857$ & & 34 \\
\hline B03-03 & $\mathrm{D}$ & $12 / 7 / 74$ & & $1858-1904$ & & 35 \\
\hline B05-01 & $\mathrm{D}$ & $12 / 7 / 74$ & & $1905-1955$ & 2530 & 36 \\
\hline F03-01 & $D$ & $12 / 8 / 74$ & & $1958-2004$ & 2555 & 1 \\
\hline F06-01 & FTE- 16 & $12 / 8 / 74$ & & $2005-2054$ & 1 & 2 \\
\hline F05-05 & $\mathrm{D}$ & $12 / 8 / 74$ & & $2055-2101$ & & 3 \\
\hline A $17-08$ & D & $12 / 8 / 74$ & & $2102-2169$ & & 4 \\
\hline F11-03 & $\mathrm{D}$ & $12 / 8 / 74$ & $17.475 \times 0.254$ & $2170-2231$ & & 5 \\
\hline A $14-08$ & FTE- 15 & $12 / 9 / 74$ & $22.86 \times 0.254$ & $2232-2303$ & & 6 \\
\hline E14-08 & FPTE-3 & $12 / 18 / 74$ & $17.475 \times 0.254$ & $2304-2432$ & & 7 \\
\hline c17-08 & $\mathrm{D}$ & $12 / 6 / 74$ & 1 & $2433-2450$ & & 8 \\
\hline E10-06 & FTE- 11 & $12 / 6 / 74$ & 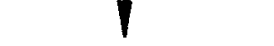 & $2451-2508$ & 1 & 8 \\
\hline F14-08 & FTE-7 & $12 / 6 / 74$ & $17.475 \times 0.254$ & $2509-2559$ & 2555 & 9 \\
\hline
\end{tabular}

(a) $D$ - driver

ID - instrumented driver

FTE - final test element

RTE - recycle test element

FBTE - fuel bed test element

FPTE - fuel pin test element

(b)

Cross section dimensions. 
TABLE 2

PEACH BOTTOM ELEMENTS GAMMA SCANNED DURING PHASE II

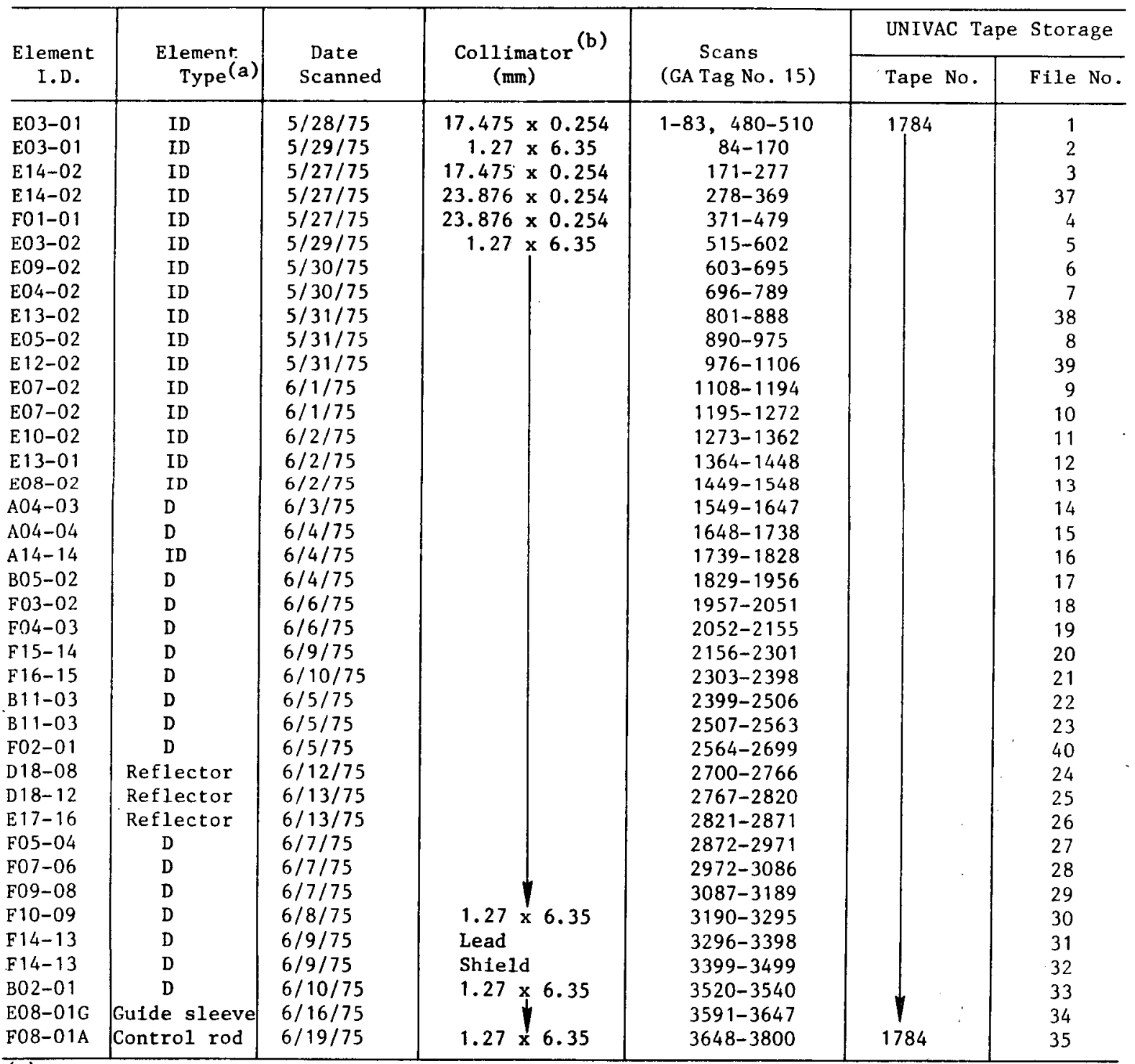

(a) D - driver

ID - instrumented driver

(b) Cross section dimensions. 
TABLE 3

NUCLEAR CONSTANTS FOR ISOTOPES USED IN PEACH BOTTOM EOL GAMMA SCANNING

\begin{tabular}{|c|c|c|c|c|c|c|c|c|}
\hline \multirow[b]{2}{*}{$\begin{array}{l}\text { Isotope } \\
\text { I.D. }\end{array}$} & \multirow{2}{*}{$\begin{array}{l}\text { Gamma } \\
\text { Energy } \\
\text { Peak } \\
(\mathrm{keV})\end{array}$} & \multirow{2}{*}{$\begin{array}{c}\text { Decay Copstant } \\
\lambda_{\left(\mathrm{a}^{-1}\right)} \\
\left(\sec ^{-1}\right)\end{array}$} & \multirow[b]{2}{*}{ Half-Life $e^{(a)}$} & \multicolumn{2}{|c|}{$\begin{array}{l}\text { Thermal } \\
\text { Fission Yield }\end{array}$} & \multirow[b]{2}{*}{$\begin{array}{l}\text { Absolute } \\
\text { Intensity }\end{array}$} & \multirow[b]{2}{*}{ Precursor } & \multirow[b]{2}{*}{$\underset{\text { Factors }}{\text { PBGST }}(c)$} \\
\hline & & & & $\begin{array}{c}\mathrm{U}-233 \\
(\%)\end{array}$ & $\begin{array}{c}\mathrm{U}-235 \\
(\%)\end{array}$ & & & \\
\hline $\mathrm{Ce}-144$ & 133 & $2.821 \times 10^{-8}$ & 284.4 days & 4.64 & 5.46 & 0.030 & & 5.1 \\
\hline$C \in-141$ & 145 & $2.466 \times 10^{-7}$ & 32.5 days & 6.58 & 5.89 & 0.480 & & 0.536 \\
\hline $\mathrm{Pa}-233$ & 312 & $2.967 \times 10^{-7}$ & 27.5 days & -- & -- & 0.0033 & & 0.446 \\
\hline$I-131$ & 364 & $6.723 \times 10^{-7}$ & 8.1 days & -- & -- & 0.820 & & 0.215 \\
\hline$R u-103$ & 497 & $2.026 \times 10^{-7}$ & 39.6 days & 1.70 & 3.14 & 0.890 & & 0.220 \\
\hline$R u-106$ & 512 & $2.174 \times 10^{-8}$ & 369.0 days & 0.257 & 0.392 & 0.210 & & 0.933 \\
\hline $\mathrm{Cs}-137$ & 662 & $7.302 \times 10^{-10}$ & 30.1 years & 6.80 & 6.27 & 0.846 & & 0.252 \\
\hline$Z r-95$ & 724 & $1.225 \times 10^{-7}$ & 65.5 days & 6.25 & 6.46 & 0.436 & & 0.518 \\
\hline $\mathrm{Cs}-134$ & 796 & $1.067 \times 10^{-8}$ & 762.9 days & $1.36 \times 10^{-3}$ & $4.5 \times 10^{-5}$ & 0.961 & $\mathrm{Xe}-133$ & 0.279 \\
\hline $\mathrm{La}-140^{(\mathrm{d})}$ & 1596 & $6.268 \times 10^{-7}$ & 12.8 days & 6.43 & 6.32 & 0.956 & $B a-140$ & 0.291 \\
\hline
\end{tabular}

(a) Data taken from Ref. 5 .

(b) Data taken from Ref. 6

${ }^{(c)}$ Corrected to CPM for relative detector effictency, attenuation, and absolute intensity (Ref. 7).

(d) Precursor Ba-140 is the direct fission yield isotope, measured through its daughter La-140. Direct yield La-140 1s decayed at time of gamma scan because of a short half-life of $40.2 \mathrm{hr}$. 
TABLE 4

FTE-6 COMPARISON OF FUEL STACK LENGTH

\begin{tabular}{|c|c|c|c|c|c|c|c|c|c|}
\hline \multirow[b]{3}{*}{ Body } & \multicolumn{6}{|c|}{ EOL Fuel Stack Length } & \multirow[b]{3}{*}{$\begin{array}{l}\text { Test } 1 \\
D=Z / S_{Z}\end{array}$} & \multirow[b]{3}{*}{$\begin{array}{l}\text { Test } 1 \\
\text { Results }\end{array}$} & \multirow[b]{3}{*}{$\begin{array}{c}\text { Test } \\
\mathrm{D}^{2}\end{array}$} \\
\hline & \multicolumn{2}{|c|}{ Metrology } & \multicolumn{2}{|c|}{$\begin{array}{l}\text { Peach Bottom } \\
\text { Gamma Scan }\end{array}$} & \multicolumn{2}{|c|}{ Relative Difference } & & & \\
\hline & $\begin{array}{c}\bar{x}_{1} \\
(\mathrm{~mm})\end{array}$ & $\begin{array}{r}\mathrm{s}_{\bar{x}_{1}} \\
(\mathrm{~mm})\end{array}$ & $\begin{array}{c}\bar{x}_{2} \\
(\mathrm{~mm})\end{array}$ & $\begin{array}{l}s_{\bar{x}_{2}}(a) \\
(\mathrm{mm})\end{array}$ & $\begin{array}{c}z=\bar{x}_{2} / \bar{x}_{1}-1 \\
(\%)\end{array}$ & $\begin{array}{r}\mathrm{S}_{\mathrm{Z}} \\
(\%)\end{array}$ & & & \\
\hline 1 & 679.8 & \pm 2.7 & 677.4 & \pm 3.3 & -0.35 & \pm 0.63 & -0.56 & $0.56<1.96$ Insignificant & 0.31 \\
\hline 2 & 677.0 & \pm 3.0 & 678.9 & \pm 2.8 & +0.28 & \pm 0.60 & +0.47 & $0.47<1.96$ Insignificant & 0.22 \\
\hline 3 & 676.5 & \pm 3.1 & 677.0 & \pm 2.2 & +0.07 & \pm 0.56 & +0.12 & $0.12<1.96$ Insignificant & 0.02 \\
\hline $\begin{array}{l}\text { Mean } \overline{\bar{x}}, S_{\bar{x}} \\
\text { RMS, } S_{\bar{x}} \\
\text { Test results }\end{array}$ & $\begin{array}{r}677.8 \\
\pm 1.4\end{array}$ & $\begin{array}{l} \pm 2.9 \\
\pm 1.7\end{array}$ & $\begin{array}{r}677.8 \\
\pm 0.8\end{array}$ & $\begin{array}{l} \pm 2.8 \\
\pm 1.6\end{array}$ & $\begin{array}{l}0.0 \\
0.0\end{array}$ & $\begin{array}{l} \pm 0.60 \\
\pm 0.34\end{array}$ & $\begin{array}{l}0.017<1.96 \\
\text { Insignificant }\end{array}$ & & $\begin{array}{l}\quad 0.18 \\
\quad \\
0.18<2.6 \\
\text { Insignificant }\end{array}$ \\
\hline
\end{tabular}

${ }^{(a)} S_{\bar{X}}$ from three single-channel analyzer strip charts. 
TABLE 5
FTE-18 COMPARISON OF FUEL BODY AND STACK LENGTHS DERIVED FROM METROLOGY AND GAMMA SCANNING

\begin{tabular}{|c|c|c|c|c|c|c|c|c|c|c|c|c|c|c|}
\hline \multirow[b]{3}{*}{ Body I.D. } & \multirow{2}{*}{\multicolumn{2}{|c|}{$\begin{array}{c}\text { BOL } \\
\text { Body Length }\end{array}$}} & \multirow{3}{*}{$\begin{array}{c}\begin{array}{c}\text { EOL } \\
\text { Body }\end{array} \\
\bar{x}_{2} \\
(\text { in.) }\end{array}$} & \multirow{3}{*}{$\begin{array}{c}\begin{array}{c}\text { PIE } \\
\text { Length }\end{array} \\
\\
\mathrm{s}_{2} \\
(\text { in.) }\end{array}$} & \multirow{2}{*}{\multicolumn{2}{|c|}{$\begin{array}{l}\text { Peach Bottom } \\
\text { EOL Y Scan } \\
\text { Body Length }\end{array}$}} & \multicolumn{2}{|c|}{$\begin{array}{l}\text { Hot Cell } \\
\text { EOL } \gamma \text { Scan }\end{array}$} & \multirow{2}{*}{\multicolumn{2}{|c|}{$\begin{array}{l}\text { Relative Change } \\
\text { from Metrology } \\
\text { (Method 1) }\end{array}$}} & \multirow{2}{*}{\multicolumn{2}{|c|}{$\begin{array}{l}\text { Relative } \\
\text { Change } \\
\text { from } \\
\text { Peach Bottom } \\
\text { Y Scan } \\
\text { (Method 2) }\end{array}$}} & \multirow{2}{*}{\multicolumn{2}{|c|}{$\begin{array}{l}\text { Relative } \\
\text { Difference } \\
\text { Between } \\
\text { Methods } 2 \text { and } 1\end{array}$}} \\
\hline & & & & & & & \multirow{2}{*}{$\begin{array}{c}\begin{array}{c}\text { Fue 1 } \\
\text { Length }\end{array} \\
\bar{x}_{4} \text { (b) } \\
(\text { in.) }\end{array}$} & \multirow{2}{*}{$\begin{array}{l}\begin{array}{c}\text { Unfueled } \\
\text { Length }\end{array} \\
\bar{x}_{2}-\bar{x}_{4} \\
(1 \mathrm{n} .)\end{array}$} & & & & & & \\
\hline & $\begin{array}{c}\bar{x}_{1} \\
(1 \mathrm{n} .)\end{array}$ & $\begin{array}{c}s_{1} \\
(\text { In. })\end{array}$ & & & $\begin{array}{l}\bar{x}_{3} \\
(\text { in. })\end{array}$ & $\begin{array}{l}s_{3} \\
(\text { in. })\end{array}$ & & & 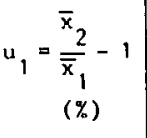 & ${ }_{(\%)}^{s}$ & $\begin{array}{c}u_{2}=\frac{\bar{x}_{3}}{\bar{x}_{1}}- \\
(\%)\end{array}$ & $\begin{array}{l}s_{u} \\
(\%)^{2}\end{array}$ & $z=\frac{u_{2}}{u_{1}}-1$ & $\mathrm{~s}_{z}$ \\
\hline Body 1 & 13.7761 & \pm 0.0021 & 13.6886 & \pm 0.0020 & 13.71 & \pm 0.016 & 13.50 & 0.19 & -0.6349 & \pm 0.0210 & -0.480 & \pm 0.117 & -0.24 & \pm 0.19 \\
\hline Body 2 & 13.7769 & \pm 0.0024 & 13.7051 & \pm 0.0020 & 13.58 & \pm 0.028 & 13.50 & 0.20 & -0.5215 & \pm 0.0226 & -1.429 & \pm 0.204 & +1.74 & \pm 0.41 \\
\hline Body 3 & 13.7826 & \pm 0.0036 & 13.7109 & \pm 0.0020 & 13.61 & \pm 0.026 & 13.42 & 0.29 & -0.5204 & \pm 0.0300 & -1.252 & \pm 0.190 & +1.41 & \pm 0.39 \\
\hline Body 4 & 13.7800 & \pm 0.0034 & 13.7128 & \pm 0.0020 & 13.95 & \pm 0.042 & 13.58 & 0.13 & -0.4881 & \pm 0.0284 & +1.234 & \pm 0.306 & -3.53 & \pm 0.64 \\
\hline Body 5 & 13.6286 & \pm 0.0033 & 13.5284 & \pm 0.0020 & 13.65 & \pm 0.040 & 13.29 & 0.24 & -0.7353 & \pm 0.0283 & +0.157 & \pm 0.295 & -1.21 & \pm 0.40 \\
\hline Body 6 & 13.7767 & \pm 0.0032 & 13.6654 & \pm 0.0020 & 13.82 & \pm 0.026 & 13.46 & $\underline{0.21}$ & -0.8079 & \pm 0.0275 & +0.314 & \pm 0.190 & -1.39 & \pm 0.24 \\
\hline Total stack & 82.5209 & \pm 0.0075 & 82.0112 & \pm 0.0049 & 82.32 & \pm 0.076 & $80.75^{(c)}$ & 1.26 & -0.6177 & \pm 0.0261 & -0.243 & \pm 0.267 & -0.61 & \pm 0.43 \\
\hline Mean $\overline{\bar{x}}, \bar{s}_{\bar{x}}$ & 13.7535 & \pm 0.0030 & 13.6685 & \pm 0.0020 & 13.72 & \pm 0.031 & 13.46 & 0.21 & -0.6180 & \pm 0.0265 & -0.243 & \pm 0.267 & -0.54 & \pm 0.41 \\
\hline RMS, $S_{\bar{x}}$ & 0.0559 & \pm 0.0012 & 0.0647 & \pm 0.0008 & 0.13 & \pm 0.013 & 0.09 & 0.05 & \pm 0.1196 & \pm 0.0108 & \pm 0.925 & \pm 0.093 & \pm 1.79 & \pm 0.17 \\
\hline
\end{tabular}

(a) Determined from five strip chart examinations.

(b) Measurement error assumed to be $\pm 0.04 \mathrm{in}$.

(c) $\mathrm{BOL}$ composite fuel length of $81.25 \mathrm{in}$. concluded. 
TABLE 6

PHASE I AND PHASE II FUEL STACK LENGTH COMPARISON FOR DRIVER ELEMENTS

\begin{tabular}{|c|c|c|c|c|c|c|c|c|}
\hline $\begin{array}{l}\text { Element } \\
\text { I.D. }\end{array}$ & $\begin{array}{l}\text { Preirradiatign } \\
\text { Stack Length, } \\
x_{1}(\mathrm{~mm})\end{array}$ & $\begin{array}{l}\text { Postirradiation } \\
\text { Stack Length, } \\
x_{2}(\mathrm{~mm})\end{array}$ & $\begin{array}{l}\mathrm{S}_{\bar{x}_{2}} \\
(\mathrm{~mm})\end{array}$ & $\begin{array}{l}\text { Difference } \\
\bar{x}_{2}-x_{1} \\
(\mathrm{~mm})\end{array}$ & $z=\bar{x}_{2} / x_{1}-1$ & $\begin{array}{c}S_{z} \\
(\%)\end{array}$ & $\begin{array}{l}\text { Fast } \\
\text { Fluence } \\
\left(10^{25} \mathrm{n} / \mathrm{m}^{2}\right)\end{array}$ & $\begin{array}{c}\text { Fue } 1 \\
\left(^{\circ} \mathrm{C}\right)\end{array}$ \\
\hline \multicolumn{9}{|c|}{ PHASE I } \\
\hline $\begin{array}{l}\text { E14-01 (c) } \\
\text { E01-01 (c) } \\
\text { F03-01 (c) } \\
\text { F05-05 } \\
\text { E02-02 } \\
\text { E09-01 } \\
\text { E11-01 } \\
\text { E15-01 } \\
\text { E07-01 } \\
\text { E05-01 } \\
\text { E15-02 } \\
\text { B13-01 } \\
\text { A03-03 } \\
\text { B02-02 } \\
\text { E11-02 } \\
\text { A05-05 } \\
\text { B03-01 } \\
\text { B14-02 } \\
\text { B03-03 } \\
\text { B05-01 } \\
\text { A } 17-08 \\
\text { E } 11-03 \\
\end{array}$ & $\begin{array}{l}2290.8 \\
2276.5 \\
2289.2 \\
2276.5 \\
2295.5 \\
2297.1 \\
2287.6 \\
2289.2 \\
2290.8 \\
2297.1 \\
2292.4 \\
2289.2 \\
2263.8 \\
2265.4 \\
2287.6 \\
2278.1 \\
2282.8 \\
2274.9 \\
2260.6 \\
2293.9 \\
2279.7 \\
2293.1\end{array}$ & $\begin{array}{l}2289.3 \\
2304.6 \\
2303.9 \\
2300.0 \\
2311.2 \\
2296.1 \\
2306.6 \\
2286.4 \\
2293.9 \\
2306.6 \\
2295.2 \\
2294.8 \\
2267.6 \\
2289.5 \\
2307.4 \\
2300.5 \\
2296.0 \\
2289.2 \\
2289.5 \\
2318.9 \\
2282.4 \\
2315.6\end{array}$ & $\begin{array}{l} \pm 2.3 \\
\pm 2.6 \\
\pm 3.6 \\
\pm 0.9 \\
\pm 2.6 \\
\pm 2.3 \\
\pm 0 \\
\pm 2.6 \\
\pm 0.7 \\
\pm 0 \\
\pm 5.8 \\
\pm 1.8 \\
\pm 2.8 \\
\pm 1.4 \\
\pm 0.5 \\
\pm 0.8 \\
\pm 1.3 \\
\pm 0.7 \\
\pm 0.7 \\
\pm 1.6 \\
\pm 0.6 \\
\pm 0.5\end{array}$ & $\begin{array}{l}-1.5 \\
+28.1 \\
+14.7 \\
+23.5 \\
+15.7 \\
-1.0 \\
+19.0 \\
-2.8 \\
+3.1 \\
+9.5 \\
+2.8 \\
+5.6 \\
+3.8 \\
+24.1 \\
+19.8 \\
+22.4 \\
+13.2 \\
+14.3 \\
+28.9 \\
+25.0 \\
+2.7 \\
+22.5\end{array}$ & $\begin{array}{l}-0.06 \\
+1.23 \\
+0.64 \\
+1.03 \\
+0.68 \\
-0.04 \\
+0.83 \\
-0.12 \\
+0.14 \\
+0.41 \\
+0.12 \\
+0.24 \\
+0.17 \\
+1.06 \\
+0.87 \\
+0.98 \\
+0.58 \\
+0.63 \\
+1.28 \\
+1.09 \\
+0.12 \\
+0.98\end{array}$ & $\begin{array}{l} \pm 0.17 \\
\pm 0.18 \\
\pm 0.21 \\
\pm 0.11 \\
\pm 0.18 \\
\pm 0.17 \\
\pm 0.14 \\
\pm 0.18 \\
\pm 0.14 \\
\pm 0.14 \\
\pm 0.29 \\
\pm 0.16 \\
\pm 0.19 \\
\pm 0.16 \\
\pm 0.14 \\
\pm 0.15 \\
\pm 0.15 \\
\pm 0.14 \\
\pm 0.15 \\
\pm 0.16 \\
\pm 0.14 \\
\pm 0.14\end{array}$ & $\begin{array}{l}2.3 \\
3.2 \\
3.1 \\
3.1 \\
3.2 \\
3.1 \\
3.1 \\
1.6 \\
3.1 \\
3.1 \\
2.0 \\
2.8 \\
0.8 \\
3.2 \\
3.1 \\
3.1 \\
3.1 \\
3.1 \\
2.7 \\
3.1 \\
1.8 \\
3.3\end{array}$ & $\begin{array}{r}945 \\
1024 \\
940 \\
969 \\
1007 \\
950 \\
1011 \\
827 \\
949 \\
958 \\
828 \\
1011 \\
\mathrm{~N} . \mathrm{D} . \\
1010 \\
1007 \\
949 \\
950 \\
999 \\
987 \\
939 \\
861 \\
1024\end{array}$ \\
\hline \multicolumn{9}{|c|}{ PHASE II } \\
\hline $\begin{array}{l}\text { E14-02 } \\
\text { F01-01 } \\
\text { E03-01 } \\
\text { E03-02 } \\
\text { E09-02 } \\
\text { E04-02 } \\
\text { E13-02 } \\
\text { E05-02 } \\
\text { E12-02 } \\
\text { E07-02 } \\
\text { E10-02 } \\
\text { E13-01 } \\
\text { E08-02 } \\
\text { A04-03 } \\
\text { A04-04 } \\
\text { A14-14 } \\
\text { B05-02 } \\
\text { B11-03(c) } \\
\text { F02-01 } \\
\text { F03-02 } \\
\text { F04-03 } \\
\text { F05-04 } \\
\text { F09-08 } \\
\text { F10-09 } \\
\text { F14-13 } \\
\text { F15-14 } \\
\text { F16-15 } \\
\text { B02-01 }\end{array}$ & $\begin{array}{l}2287.6 \\
2281.2 \\
2271.7 \\
2287.6 \\
2282.8 \\
2282.8 \\
2290.8 \\
2298.7 \\
2284.4 \\
2292.4 \\
2292.4 \\
2290.8 \\
2292.4 \\
2279.7 \\
2282.8 \\
2290.8 \\
2278.1 \\
2273.3 \\
2289.2 \\
2282.8 \\
2260.6 \\
2284.4 \\
2284.4 \\
2290.8 \\
2279.1 \\
2308.4 \\
2304.3 \\
2310.0\end{array}$ & $\begin{array}{l}2308.9 \\
2307.7 \\
2282.8 \\
2309.4 \\
2300.3 \\
2304.5 \\
2307.8 \\
2313.3 \\
2290.1 \\
2299.9 \\
2307.8 \\
2304.2 \\
2307.8 \\
2302.4 \\
2306.6 \\
2306.5 \\
2306.5 \\
2306.6 \\
2308.0 \\
2306.6 \\
2286.2 \\
2293.7 \\
2298.9 \\
2298.2 \\
2303.7 \\
2309.4 \\
2304.5 \\
2311.5\end{array}$ & $\begin{array}{l} \pm 3.4 \\
\pm 1.9 \\
\pm 8.1 \\
\pm 3.2 \\
\pm 6.3 \\
\pm 1.2 \\
\pm 0.6 \\
\pm 1.9 \\
\pm 10.5 \\
\pm 1.4 \\
\pm 2.0 \\
\pm 2.9 \\
\pm 1.2 \\
\pm 3.3 \\
\pm 0 \\
\pm 0.1 \\
\pm 0 \\
\pm 0 \\
\pm 0.9 \\
\pm 0.1 \\
\pm 2.2 \\
\pm 1.3 \\
\pm 2.7 \\
\pm 4.6 \\
\pm 1.4 \\
\pm 0.5 \\
\pm 6.7 \\
\pm 1.4\end{array}$ & $\begin{array}{l}+21.3 \\
+26.5 \\
+11.1 \\
+21.8 \\
+17.5 \\
-2.1 \\
+17.0 \\
+14.6 \\
+5.7 \\
+7.5 \\
+15.4 \\
+13.4 \\
+15.4 \\
+22.7 \\
+23.8 \\
+15.7 \\
+28.4 \\
+33.3 \\
+18.8 \\
+23.8 \\
+25.6 \\
+9.3 \\
+14.5 \\
+7.4 \\
+24.6 \\
+20.2 \\
+5.8 \\
+25.5\end{array}$ & $\begin{array}{l}+0.93 \\
+1.16 \\
+0.49 \\
+0.95 \\
+0.77 \\
-0.09 \\
+0.74 \\
+0.64 \\
+0.25 \\
+0.33 \\
+0.67 \\
+0.58 \\
+0.67 \\
+1.00 \\
+1.04 \\
+0.69 \\
+1.25 \\
+1.46 \\
+0.82 \\
+1.04 \\
+1.13 \\
+0.41 \\
+0.63 \\
+0.32 \\
+1.08 \\
+0.88 \\
+0.25 \\
+1.12\end{array}$ & $\begin{array}{l} \pm 0.20 \\
\pm 0.16 \\
\pm 0.38 \\
\pm 0.20 \\
\pm 0.31 \\
\pm 0.15 \\
\pm 0.14 \\
\pm 0.16 \\
\pm 0.48 \\
\pm 0.15 \\
\pm 0.16 \\
\pm 0.19 \\
\pm 0.15 \\
\pm 0.20 \\
\pm 0.14 \\
\pm 0.14 \\
\pm 0.14 \\
\pm 0.14 \\
\pm 0.15 \\
\pm 0.14 \\
\pm 0.17 \\
\pm 0.15 \\
\pm 0.18 \\
\pm 0.24 \\
\pm 0.15 \\
\pm 0.14 \\
\pm 0.32 \\
\pm 0.15\end{array}$ & $\begin{array}{l}2.6 \\
3.1 \\
3.1 \\
3.1 \\
3.1 \\
3.1 \\
2.9 \\
3.1 \\
3.0 \\
3.2 \\
3.2 \\
2.7 \\
3.1 \\
3.2 \\
3.1 \\
2.7 \\
3.1 \\
3.3 \\
3.2 \\
3.1 \\
3.2 \\
3.2 \\
3.3 \\
3.3 \\
2.9 \\
2.4 \\
1.6 \\
3.2\end{array}$ & $\begin{array}{r}951 \\
1023 \\
960 \\
986 \\
947 \\
957 \\
980 \\
963 \\
1000 \\
993 \\
995 \\
967 \\
948 \\
987 \\
948 \\
995 \\
950 \\
1029 \\
997 \\
986 \\
984 \\
994 \\
1018 \\
1020 \\
1002 \\
992 \\
860 \\
1004\end{array}$ \\
\hline $\begin{array}{l}\text { Mean } \bar{x}, \bar{S}_{x}, \\
\bar{S}_{\bar{x}}\end{array}$ & 2285.7 & 2300.8 & \pm 3.0 & +15.6 & +0.68 & \pm 0.19 & 2.9 & 971 \\
\hline RMS, $S=$ & \pm 10.6 & \pm 9.8 & \pm 0.4 & \pm 9.2 & \pm 0.40 & \pm 0.03 & \pm 0.5 & \pm 46 \\
\hline
\end{tabular}

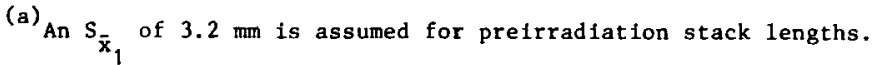

(b) Time and volume averaged.

(c) Scanned at ORNL. 
TABLE 7

COMPARISON OF STACK LENGTH OF TEST ELEMENTS

\begin{tabular}{|c|c|c|c|c|c|c|c|c|c|}
\hline $\begin{array}{c}\text { Element } \\
\text { I.D. }\end{array}$ & $\begin{array}{l}\text { Preirradiatign } \\
\text { Stack Length, } \\
\quad x_{1}(\mathrm{~mm})\end{array}$ & $\begin{array}{c}\text { Postirradiation } \\
\text { Stack Length, } \\
x_{2}(\mathrm{~mm})\end{array}$ & $\begin{array}{c}\mathrm{S}_{\overline{\mathrm{x}}_{2}} \\
(\mathrm{~mm})\end{array}$ & $\begin{array}{c}\text { Dif f erence } \\
\bar{x}_{2}-x_{1} \\
m_{(m)}\end{array}$ & $\begin{array}{c}z=\bar{x}_{2} / x_{1}-1 \\
(\%)\end{array}$ & $\begin{array}{l}\mathrm{S}_{2} \\
(\%)\end{array}$ & $\begin{array}{l}\text { Fast } \\
\text { Fluence } \\
\left(10^{25} \mathrm{n} / \mathrm{m}^{2}\right)\end{array}$ & $\begin{array}{l}\text { Fuel } \\
\text { Temp. (b) } \\
\left({ }^{\circ} \mathrm{c}\right)\end{array}$ & Fuel Geometry \\
\hline F06-01, FIE-18(b) & 2063.8 & 2051.1 & \pm 0.2 & -210.3 & -0.62 & \pm 0.03 & 1.9 & NA & Molded bed \\
\hline D14-08, FTE-8 & 2275.8 & 2257.7 & \pm 0.8 & -18.1 & -0.80 & \pm 0.14 & 2.1 & $\mathrm{NA}$ & Rods \\
\hline E10-01, FTE-13 & 2290.8 & 2269.5 & \pm 0 & -21.3 & -0.93 & \pm 0.14 & 1.8 & NA & Rods \\
\hline D06-01, FTE-9 & 2337.5 & 2257.0 & \pm 0.1 & -80.5 & -3.44 & \pm 0.13 & 2.3 & 939 & Rods \\
\hline E02-01, FTE-10 & 2273.3 & 2253.4 & \pm 0.6 & -19.9 & -0.88 & \pm 0.14 & 3.2 & $\mathrm{NA}$ & Rods \\
\hline C14-08, FTE-5 & 2287.6 & 2269.5 & -- & -18.1 & -0.79 & \pm 0.14 & 3.0 & 965 & Rods \\
\hline F06-01, FTE-16 & 2275.6 & 2262.6 & \pm 0.3 & -13.0 & -0.57 & \pm 0.14 & 1.8 & $\mathrm{NA}$ & Rods \\
\hline A $14-08$, FTE-15 & 2287.5 & 2269.1 & \pm 2.4 & -18.4 & -0.80 & \pm 0.17 & 1.7 & 1064 & Rods \\
\hline D10-06, RTE-6 & 2294.7 & 2274.4 & \pm 0.9 & -20.3 & -0.88 & \pm 0.14 & 3.3 & 1010 & Rods \\
\hline C10-06, RTE-5 & 2290.3 & 2275.5 & \pm 0.6 & -14.8 & -0.65 & \pm 0.14 & 3.3 & 1005 & Rods \\
\hline F10-06, RTE-8 & 2300.1 & 2287.5 & \pm 8.0 & -12.6 & -0.55 & \pm 0.37 & 3.3 & 991 & Rods \\
\hline C05-04, FBTE- 1 & 2298.7 & 2227.7 & \pm 0.9 & -71.0 & -3.09 & \pm 0.14 & 3.1 & NA & Rods \\
\hline D09-04, FBTE-5 & 2277.7 & 2236.6 & \pm 0.7 & -41.1 & -1.80 & \pm 0.14 & 3.3 & NA & Blended bed \\
\hline A $11-11$, FBTE-2 & 2281.2 & 2263.2 & \pm 2.4 & -22.4 & -0.98 & \pm 0.17 & 3.1 & NA & Rods \\
\hline B $14-08$, FBTE- 3 & 2276.0 & 2252.3 & \pm 1.3 & -23.7 & -1.04 & \pm 0.15 & 3.1 & NA & Rods \\
\hline E14-08, FPTE-3 (b) & 2234.7 & 2226.9 & \pm 1.4 & -7.8 & -0.35 & \pm 0.16 & 2.2 & NA & Compacts \\
\hline$\overline{M e a n} \bar{x}$ & 2284.9 & 2248.5 & \pm 2.3 & -36.7 & -29.2 & \pm 0.17 & 2.6 & 996 & \\
\hline
\end{tabular}

(a) A preirradiation $s_{\bar{x}_{1}}$ of $3.2 \mathrm{~mm} \mathrm{is} \mathrm{assumed,} \mathrm{except} \mathrm{for} \mathrm{FTE-18} \mathrm{with} s_{\mathrm{x}_{1}}= \pm 0.1 \mathrm{~mm}$ (see Table 6).

(b) Element time-weighed average fuel temperature.

${ }^{(c)}$ Scanned at GA hot cell. 
TABLE 8

BURNUP COMPARISON FOR DRIVER AND TEST ELEMENTS SCANNED DURING PHASE I OF PEACH BOTTOM EOL PROGRAM

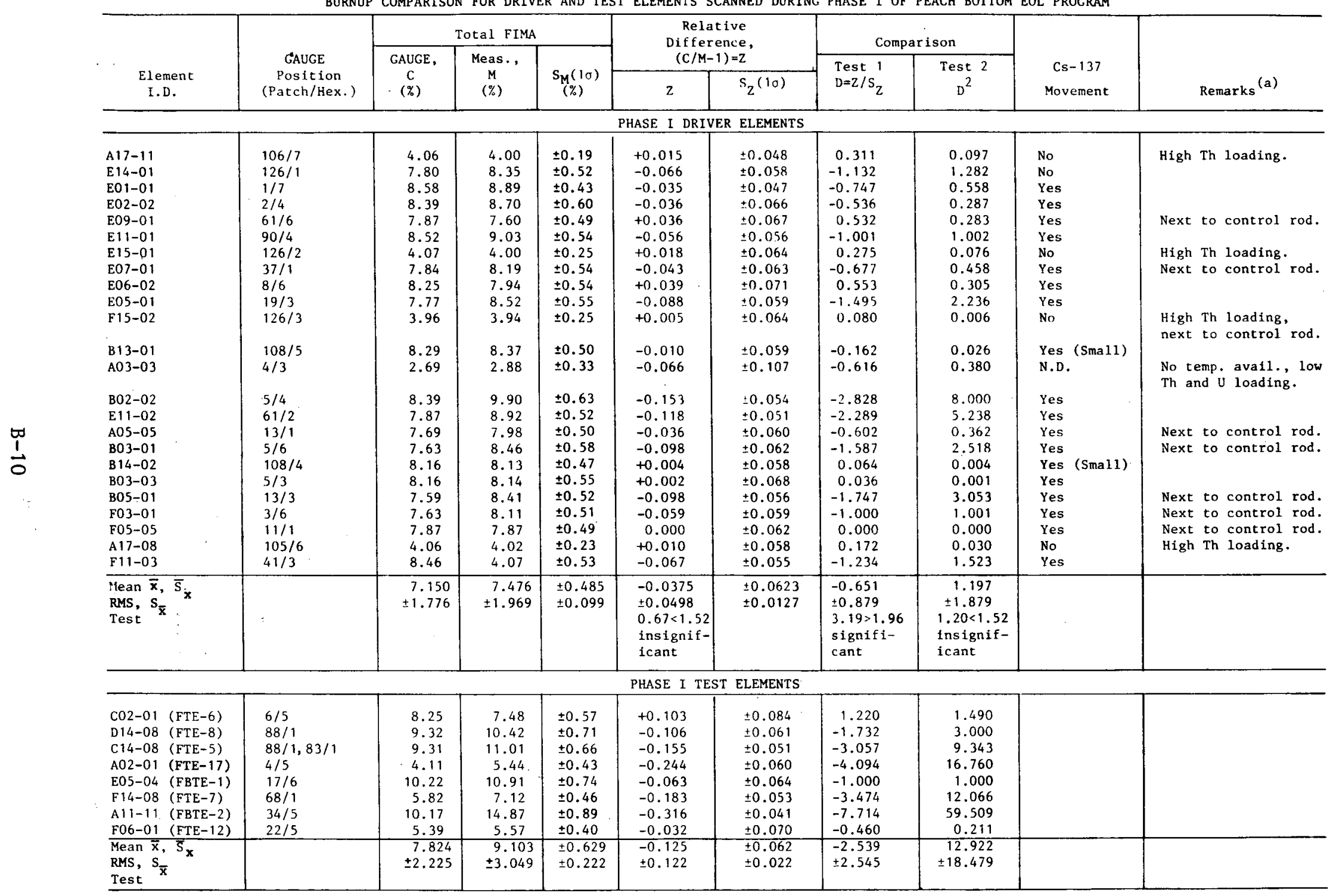

${ }^{(a)}$ All elements are unperturbed except where noted. 
TABLE 9

BURNUP COMPARISON OF DRIVER ELEMENTS SCANNED DURING PHASE II OF PEACH BOTTOM EOL PROGRAM

\begin{tabular}{|c|c|c|c|c|c|c|c|c|c|c|}
\hline \multirow[b]{2}{*}{$\begin{array}{l}\text { E1ement } \\
\text { I.D. }\end{array}$} & \multirow[b]{2}{*}{$\begin{array}{c}\text { GAUGE } \\
\text { Position } \\
\text { (Patch/Hex.) }\end{array}$} & \multicolumn{3}{|c|}{ Total FIMA } & \multicolumn{2}{|c|}{$\begin{array}{c}\text { Relative } \\
\text { Difference }\end{array}$} & \multicolumn{2}{|c|}{ Comparison } & \multirow[b]{2}{*}{$\begin{array}{c}\text { Cs-137 } \\
\text { Movement }\end{array}$} & \multirow[b]{2}{*}{ Remarks ${ }^{(a)}$} \\
\hline & & $\begin{array}{l}\text { GAUGE, } \\
\text { C } \\
(\%)\end{array}$ & $\begin{array}{c}\text { Meas., } \\
M \\
(\%)\end{array}$ & $\begin{array}{c}S_{M}(10) \\
(\%)\end{array}$ & $(C / M-1)=2$ & $\frac{s_{Z}(1 \sigma)}{?}$ & $\begin{array}{l}\text { Test } \quad{ }^{\prime} \\
D=7 . / S_{Z}\end{array}$ & $\begin{array}{c}\text { Test } 2 \\
\mathrm{D}^{2}\end{array}$ & & \\
\hline \multicolumn{11}{|c|}{ PHASE II DRIVER ELEMENTS } \\
\hline $\begin{array}{l}E 03-01 \\
\text { E14-02 }\end{array}$ & $\begin{array}{l}2 / 6 \\
126 / 4\end{array}$ & $\begin{array}{l}7.85 \\
8.11\end{array}$ & $\begin{array}{l}8.20 \\
8.78\end{array}$ & $\begin{array}{l} \pm 0.24 \\
\pm 0.42\end{array}$ & -0.043 & \pm 0.028 & -1.523 & 2.321 & Yes & \\
\hline FO1-01. & $1 / 2$ & 8.54 & \multicolumn{2}{|c|}{ Not Determined } & & & & 2.300 & Yes & No calibration. \\
\hline E03-02 & $2 / 1$ & 8.16 & 8.19 & \pm 0.24 & -0.004 & \pm 0.029 & -0.125 & 0.016 & Yes & \\
\hline E09-02 & $61 / 5$ & 7.86 & 7.13 & \pm 0.21 & +0.102 & \pm 0.032 & 3.153 & 9.943 & Yes & Next to control rod. \\
\hline $\mathrm{E} 04-02$ & $2 / 7$ & 7.80 & 7.54 & \pm 0.24 & +0.034 & 10.033 & 1.047 & 1.097 & $\mathrm{Yes}$ & Next to control rod. \\
\hline E13-02 & $91 / 7$ & 8.31 & 7.67 & \pm 0.20 & +0.083 & -0.029 & 2.954 & 8.723 & No & \\
\hline EOS-02 & $8 / 5$ & 7.87 & 6.99 & \pm 0.20 & +0.126 & \pm 0.032 & 3.908 & 15.273 & Yes & Next to control rod. \\
\hline E) $2-02$ & $91 / 6$ & 8.44 & 8.07 & \pm 0.21 & +0.046 & \pm 0.027 & 1.685 & 2.838 & Yes & \\
\hline $1807-02$ & $37 / 4$ & 8.25 & 8.50 & \pm 0.18 & -0.029 & \pm 0.021 & -1.431 & 2.048 & Yes & \\
\hline E10-02 & $61 / 1$ & 8.29 & 7.85 & \pm 0.21 & +0.056 & \pm 0.028 & 1.984 & 3.936 & Yes & \\
\hline E13-01 & $126 / 5$ & 8.24 & 8.17 & \pm 0.22 & +0.009 & \pm 0.027 & 0.315 & 0.100 & No & \\
\hline E08-02 & $37 / 3$ & 7.86 & 6.94 & \pm 0.20 & +0.133 & \pm 0.033 & 4.062 & 16.496 & Yes & Ntexe to control rod. \\
\hline $\mathrm{A} 04-03$ & $4 / 2$ & 8.06 & 7.80 & \pm 0.23 & +0.033 & \pm 0.030 & 1.094 & 1.197 & Yes & \\
\hline $\mathrm{A} 04-04$ & $13 / 5$ & 7.63 & 8.05 & \pm 0.22 & -0.052 & \pm 0.026 & -2.014 & 4.057 & Yes & Next to control rod. \\
\hline A14-14 & $108 / 6$ & 8.16 & 8.11 & \pm 0.21 & +0.006 & \pm 0.026 & 0.237 & 0.056 & No & \\
\hline B05-02 & $5 / 4$ & 7.69 & 7.79 & \pm 0.22 & -0.013 & \pm 0.028 & -0.460 & 0.212 & Yes & Next to control rod. \\
\hline F03-02 & $3 / 1$ & 8.05 & 7.60 & \pm 0.19 & +0.059 & \pm 0.026 & 2.236 & 5.0000 & Yes & \\
\hline F04-03 & $3 / 2$ & 8.06 & 7.39 & \pm 0.19 & +0.091 & \pm 0.028 & 3.233 & 10.453 & Yes & \\
\hline F15-14 & $101 / 3$ & 8.13 & 9.03 & \pm 0.18 & -0.100 & \pm 0.018 & -5.554 & 30.842 & No & \\
\hline B10-15 & $139 / 5$ & 4.05 & 4.19 & \pm 0.09 & -0.033 & $: 0.020$ & -1.609 & 2.590 & No & \\
\hline B11-03 & $49 / 3$ & 8.46 & 7.62 & \pm 0.20 & +0.110 & \pm 0.029 & 3.783 & 14.311 & Yes & \\
\hline FO2-01 & $3 / 5$ & 8.23 & 7.71 & \pm 0.19 & +0.067 & \pm 0.026 & 2.564 & 6.574 & Yes & \\
\hline F05-04 & $11 / 6$ & 8.17 & 7.19 & \pm 0.17 & +0.136 & \pm 0.027 & 5.073 & 25.738 & Yes & \\
\hline F07-06 & $24 / 4$ & 3.04 & \multirow{4}{*}{\multicolumn{2}{|c|}{$\begin{array}{l}\text { Not Determined } \\
\text { Not Determined } \\
\text { Not Determined } \\
\text { Not Determined }\end{array}$}} & & & & & - & No caltbration. \\
\hline F09-08 & $44 / 5$ & 8.38 & & & & & & & Yes & No calibration. \\
\hline F12-09 & $44 / 1$ & 8.37 & & & & & & & Yes & No calibration. \\
\hline F14-13 & $101 / 4$ & 8.12 & & & & & & & - & No calfbration. \\
\hline B02-01 & $5 / 5$ & 8.23 & \multirow{2}{*}{\multicolumn{2}{|c|}{$\begin{array}{l}8.57 \quad 1 \quad \pm 0.21 \\
\text { Not Determined }\end{array}$}} & -0.040 & $: 0.024$ & -1.686 & 2.842 & Yes & \\
\hline F12-11 & $70 / 6$ & 8.34 & & & & & & & - & No callibration. \\
\hline $\begin{array}{l}\text { Mean } \bar{x}, \bar{s}_{\mathbf{x}} \\
\text { RMS, } S_{\bar{x}} \\
\text { Test }\end{array}$ & & $\begin{array}{r}7.915 \\
\pm 0.834\end{array}$ & $\begin{array}{r}7.712 \\
\pm 0.904 \\
\end{array}$ & $\begin{array}{l} \pm 0.218 \\
\pm 0.044\end{array}$ & $\begin{array}{l}+0.0292 \\
\pm 0.0674 \\
6.05>1.52 \\
\text { Significant }\end{array}$ & $\begin{array}{l} \pm 0.028 \\
\pm 0.0058\end{array}$ & $\begin{array}{c}0.883 \\
\pm 2.508 \\
4.33>1.96 \\
\text { Significant }\end{array}$ & \begin{tabular}{|c|}
7.069 \\
\pm 8.044 \\
$7.07>1.52$ \\
Significant
\end{tabular} & & \\
\hline \multicolumn{11}{|c|}{ PHASE I \& PHASE II DRIVER ELEMENTS } \\
\hline Total $\bar{x}, s_{\bar{z}}$ & & 7.533 & 7.594 & \pm 0.376 & -0.0042 & \pm 0.0478 & 0.116 & 4.133 & & \\
\hline $\begin{array}{l}\text { RMS, } \\
\text { Test }\end{array}$ & & \pm 1.439 & \pm 1.537 & \pm 0.054 & $\begin{array}{c} \pm 0.0680 \\
3.95>1.35 \\
\text { Significant }\end{array}$ & \pm 0.0069 & $\begin{array}{c} \pm 2.030 \\
0.80<1.96 \\
\text { Not } \\
\text { Significant }\end{array}$ & $\begin{array}{l} \pm 6.537 \\
4.13>1.35 \\
\text { Signif icant }\end{array}$ & & \\
\hline
\end{tabular}

\footnotetext{
(a) All elements are unperturbed except where noted.
} 
TABLE 10

Cs-137 INVENTORY COMPARISON OF PHASE I DRIVER ELEMENTS

\begin{tabular}{|c|c|c|c|c|c|c|c|c|c|c|c|}
\hline \multirow[b]{2}{*}{$\begin{array}{l}\text { Element } \\
\text { I.D. }\end{array}$} & \multirow[b]{2}{*}{$\begin{array}{c}\text { GAUGE } \\
\text { Position } \\
\text { (Patch/Hex.) }\end{array}$} & \multicolumn{3}{|c|}{ Cs-137 Inventory } & \multicolumn{2}{|c|}{$\begin{array}{l}\text { Relative } \\
\text { Difference }\end{array}$} & \multicolumn{2}{|c|}{ Comparison } & \multicolumn{2}{|c|}{$\begin{array}{c}\text { Fission Product } \\
\text { Trap Activity }\end{array}$} & \multirow[b]{2}{*}{$\begin{array}{c}\text { Cs-137 } \\
\text { Movement }\end{array}$} \\
\hline & & $\begin{array}{c}\text { GAUGE, } \\
\text { C } \\
\text { (Ci) }\end{array}$ & $\begin{array}{c}\text { MEAS. , } \\
\text { M } \\
(\mathrm{C} i)\end{array}$ & $\begin{array}{l}\mathrm{S}_{\mathrm{M}}(1 \sigma) \\
(\mathrm{C} i)\end{array}$ & $(C / M-1)=2$ & $s_{z}(1 \sigma)$ & $\mathrm{D}=\mathrm{Z} / \mathrm{S}_{\mathrm{Z}}$ & $\mathrm{D}^{2}$ & $\begin{array}{l}\mathrm{Cs}-137 \\
(\mathrm{Ci} \pm 1 \sigma)\end{array}$ & $\begin{array}{l}\text { Cs }-134 \\
(\mathrm{C} i \pm 1 \sigma)\end{array}$ & \\
\hline \multicolumn{12}{|c|}{ PHASE I DRIVER ELEMENTS } \\
\hline$A 17-11$ & $106 / 7$ & 344.7 & 339.0 & \pm 9.3 & 0.017 & \pm 0.028 & 0.60 & 0.36 & $\mathrm{NA}$ & $\mathrm{NA}$ & No \\
\hline E $14-01$ & $126 / 1$ & 392.1 & 420.0 & \pm 10.4 & -0.066 & \pm 0.023 & -2.87 & 8.26 & $0.5 \pm 0.1$ & $<0.1$ & No \\
\hline E01-01 & $1 / 7$ & 431.4 & 447.0 & \pm 13.1 & -0.035 & \pm 0.028 & -1.23 & 1.52 & $0.4 \pm 0.1$ & $0.2 \pm 0.1$ & Yes \\
\hline $\mathrm{E} 02-02$ & $2 / 4$ & 421.8 & 438.0 & \pm 12.6 & -0.037 & \pm 0.028 & -1.34 & 1.78 & $0.4 \pm 0.1$ & $<0.1$ & Yes \\
\hline E09-01 & $61 / 6$ & 395.7 & 381.0 & \pm 10.4 & 0.039 & \pm 0.028 & 1.36 & 1.85 & $0.5 \pm 0.1$ & $0.2 \pm 0.1$ & Yes \\
\hline E11-01 & $90 / 4$ & 428.4 & 453.0 & \pm 11.5 & -0.054 & \pm 0.024 & -2.26 & 5.12 & $0.5 \pm 0.1$ & $<0.1$ & Yes \\
\hline E15-01 & $126 / 2$ & 345.6 & 339.0 & \pm 9.3 & 0.019 & \pm 0.028 & 0.70 & 0.49 & $0.4 \pm 0.2$ & $<0.1$ & No \\
\hline E07-01 & $37 / 1$ & 394.2 & 411.0 & \pm 11.5 & -0.041 & \pm 0.027 & -1.52 & 2.32 & $0.5 \pm 0.2$ & $<0.1$ & Yes \\
\hline E06-02 & $8 / 6$ & 414.8 & 399.0 & \pm 11.5 & 0.040 & \pm 0.030 & 1.32 & 1.75 & $0.6 \pm 0.1$ & $<0.1$ & Yes \\
\hline E05-01 & $19 / 3$ & 390.7 & 429.0 & \pm 12.0 & -0.089 & \pm 0.025 & -3.51 & 12.28 & $0.5 \pm 0.1$ & $<0.1$ & Yes \\
\hline E15-02 & $126 / 3$ & 336.2 & 333.0 & \pm 8.8 & 0.010 & \pm 0.027 & 0.36 & 0.13 & $0.4 \pm 0.1$ & $<0.1$ & No \\
\hline B 13-01 & $108 / 5$ & 416.8 & 420.0 & \pm 11.0 & -0.008 & \pm 0.026 & -0.27 & 0.09 & $0.5 \pm 0.2$ & $<0.1$ & Yes (Sma11) \\
\hline $\mathrm{AO} 3-03$ & $4 / 3$ & 100.5 & 108.0 & \pm 6.6 & -0.069 & \pm 0.057 & -1.22 & 1.48 & $0.3 \pm 0.1$ & $<0.1$ & N.D. \\
\hline $\mathrm{B} 02-02$ & $5 / 4$ & 421.8 & 498.0 & \pm 14.2 . & -0.153 & \pm 0.024 & -6.34 & 40.14 & $<0.1$ & $<0.1$ & Yes \\
\hline E11-02 & $61 / 2$ & 395.7 & 450.0 & \pm 11.5 & -0.121 & \pm 0.022 & -5.37 & 28.83 & $0.5 \pm 0.2$ & $<0.1$ & Yes \\
\hline A05-05 & $13 / 1$ & 386.6 & 402.0 & \pm 11.0 & -0.038 & \pm 0.026 & -1.46 & 2.12 & $0.4 \pm 0.1$ & $0.2 \pm 0.1$ & Yes \\
\hline B03-01 & $5 / 6$ & 383.6 & 426.0 & \pm 12.0 & -0.100 & \pm 0.025 & -3.92 & 15.40 & $0.3 \pm 0.1$ & $0.1 \pm 0.1$ & Yes \\
\hline B 14-02 & $108 / 4$ & 410.3 & 408.0 & \pm 10.4 & 0.006 & \pm 0.026 & 0.22 & 0.05 & $0.5 \pm 0.1$ & $0.1 \pm 0.1$ & Yes (Sma11) \\
\hline В03-03 & $5 / 3$ & 410.3 & 408.0 & \pm 12.0 & 0.006 & \pm 0.026 & 0.22 & 0.05 & $0.4 \pm 0.1$ & $<0.1$ & Yes \\
\hline B05-01 & $13 / 3$ & 381.6 & 423.0 & \pm 11.5 & -0.098 & \pm 0.025 & -3.99 & 15.93 & $0.4 \pm 0.1$ & $<0.1$ & Yes \\
\hline F03-01 & $3 / 6$ & 383.6 & 404.8 & \pm 11.0 & -0.060 & \pm 0.025 & -2.36 & 5.57 & $0.4 \pm 0.1$ & $<0.1$ & Yes \\
\hline F05-05 & $11 / 1$ & 395.7 & 396.0 & \pm 11.0 & -0.001 & \pm 0.028 & -0.03 & 0.01 & $0.5 \pm 0.1$ & $<0.1$ & Yes \\
\hline A $17-08$ & $105 / 6$ & 344.7 & 342.0 & \pm 8.8 & 0.008 & \pm 0.026 & 0.30 & 0.09 & $0.5 \pm 0.1$ & $<0.1$ & No \\
\hline F11-03 & $41 / 3$ & 425.4 & 456.0 & \pm 11.5 & -0.067 & \pm 0.024 & -2.85 & 8.14 & $0.5 \pm 0.1$ & $<0.1$ & Yes \\
\hline Mean $\bar{x}, \bar{s}_{x}$ & & 381.3 & 397.8 & \pm 11.1 & -0.038 & \pm 0.028 & -1.48 & 6.41 & $0.43 \pm 0.12$ & $0.035 \pm 0.05$ & \\
\hline $\mathrm{RMS}, \mathrm{S}_{\mathbf{x}}$ & & \pm 64.5 & \pm 69.4 & \pm 2.3 & \pm 0.050 & \pm 0.006 & \pm 2.06 & \pm 9.82 & $\pm 0.12 \pm 0.025$ & $\pm 0.07 \pm 0.01$ & \\
\hline Test & & & & & $\begin{array}{l}3.08<1.52 \\
\text { Significant }\end{array}$ & & $\begin{array}{l}4.46>1.96 \\
\text { Significant }\end{array}$ & $\begin{array}{l}6.41>1.52 \\
\text { Significant }\end{array}$ & & & \\
\hline
\end{tabular}


TABLE 11

CS-137 INVENTORY COMPARISON OF PHASE I AND II DRIVER ELEMENTS

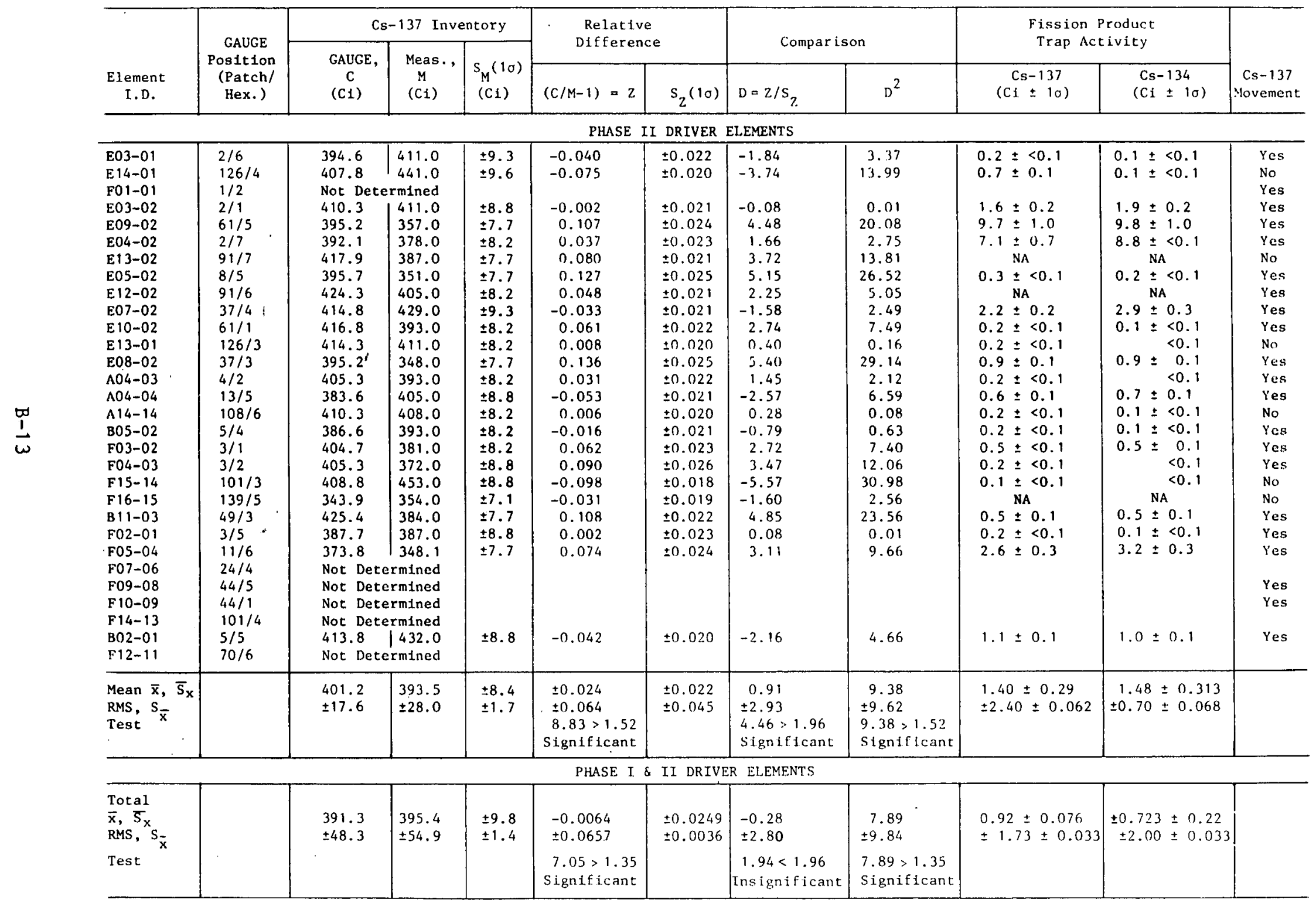


TABLE 12

F03-01 Cs-137 INVENTORY COMPARISON

\begin{tabular}{|c|c|c|c|c|c|c|c|c|c|c|c|}
\hline \multirow{3}{*}{$\begin{array}{c}\text { Compact } \\
\text { I.D. }\end{array}$} & \multirow{3}{*}{$\begin{array}{c}\text { FISS-PROD } \\
\text { Calc. } \\
\text { Cs-137 } \\
\text { Inventory } \\
\text { (Ci) }\end{array}$} & \multicolumn{8}{|c|}{ ORNL Scans } & \multirow{2}{*}{\multicolumn{2}{|c|}{$\begin{array}{c}\text { Peach } \\
\text { Bottom Scan } \\
\quad \text { (Total Ci) } \\
\end{array}$}} \\
\hline & & \multicolumn{2}{|c|}{ Compact (Ci) } & \multicolumn{2}{|c|}{ Sleeve (Ci) } & \multicolumn{2}{|c|}{ Spine (Ci) } & \multicolumn{2}{|c|}{ Total (Ci) } & & \\
\hline & & Meas. & $\pm 1 \sigma(a)$ & Meas. & $\pm 10(\mathrm{~b})$ & Meas. & $\pm 10(b)$ & Meas. & $\pm 10(\mathrm{~b})$ & Meas. & \pm 10 \\
\hline 1 & 6.4 & 8.20 & 0.21 & 0.0032 & 0.00008 & 0.0080 & 0.0002 & 8.21 & 0.21 & 9.50 & 1.30 \\
\hline 2 & 7.7 & 9.43 & 0.24 & 0.0066 & 0.00017 & 0.067 & 0.0017 & 9.50 & 0.24 & 9.23 & 0.87 \\
\hline 3 & 8.8 & 10.70 & 0.62 & 0.0108 & 0.0006 & 0.154 & 0.0089 & 10.86 & 0.63 & 10.43 & 1.01 \\
\hline 4 & 10.0 & 12.50 & 0.28 & 0.0233 & 0.0005 & 0.201 & 0.0045 & 12.72 & 0.28 & 14.47 & 1.26 \\
\hline 5 & 11.2 & 14.90 & 0.35 & 0.0352 & 0.0008 & 0.223 & 0.0052 & 15.19 & 0.36 & 16.84 & 1.29 \\
\hline 6 & 12.2 & 16.40 & 0.80 & 0.0811 & 0.0040 & 0.250 & 0.012 & 16.73 & 0.82 & 17.62 & 1.31 \\
\hline 7 & 13.0 & 17.40 & 0.69 & 0.2653 & 0.011 & 0.257 & 0.010 & 17.92 & 0.71 & 20.39 & 1.45 \\
\hline 8 & 13.6 & 22.20 & 0.86 & 0.9841 & 0.038 & 0.378 & 0.015 & 23.56 & 0.91 & 23.84 & 1.51 \\
\hline 9 & 14.0 & 20.70 & 0.21 & 2.195 & 0.022 & 0.622 & 0.006 & 23.52 & 0.24 & 27.03 & 1.53 \\
\hline 10 & 14.4 & 23.70 & 1.02 & 1.753 & 0.075 & 0.774 & 0.033 & 26.23 & 1.13 & 27.44 & 1.57 \\
\hline 11 & 14.6 & 22.50 & 0.43 & 2.222 & 0.042 & 0.887 & 0.017 & 25.61 & 0.49 & 26.99 & 1.48 \\
\hline 12 & 14.9 & 17.50 & 0.31 & 3.308 & 0.058 & 0.887 & 0.016 & 21.70 & 0.38 & 23.11 & 1.48 \\
\hline 13 & 15.2 & 18.90 & 1.06 & 2.536 & 0.142 & 0.793 & 0.044 & 22.23 & 1.24 & 20.43 & 1.38 \\
\hline 14 & 15.4 & 13.50 & 0.62 & 2.032 & 0.093 & 0.646 & 0.030 & 16.18 & 0.74 & 16.63 & 1.46 \\
\hline 15 & 15.4 & 11.30 & 0.46 & 2.253 & 0.092 & 0.553 & 0.023 & 14.11 & 0.57 & 12.52 & 1.38 \\
\hline 16 & 15.6 & 10.30 & 0.88 & 2.328 & 0.199 & 0.618 & 0.053 & 13.25 & 1.13 & 10.77 & 1.24 \\
\hline 17 & 15.6 & 8.26 & 0.46 & 2.930 & 0.163 & 0.745 & 0.041 & 11.94 & 0.66 & 9.72 & 1.30 \\
\hline 18 & 15.6 & 5.99 & 0.21 & 3.003 & 0.105 & 0.370 & 0.013 & 9.36 & 0.33 & 8.71 & 1.42 \\
\hline 19 & 15.4 & 4.88 & 0.09 & 1.987 & 0.037 & 0.178 & 0.003 & 7.05 & 0.13 & 9.35 & 1.51 \\
\hline 20 & 15.3 & 7.92 & 0.46 & 2.518 & 0.146 & 0.429 & 0.025 & 10.87 & 0.63 & 10.96 & 1.45 \\
\hline 21 & 15.1 & 5.77 & 0.09 & 1.985 & 0.031 & 0,480 & 0.007 & 8.24 & 0.13 & 10.28 & 1.23 \\
\hline 22 & 14.7 & 4.73 & 0.16 & 1.106 & 0.037 & 0.220 & 0.007 & 6.06 & 0.21 & 5.64 & 1.25 \\
\hline 23 & 14.3 & 5.50 & 0.22 & 0.787 & 0.031 & 0.119 & 0.004 & 6.41 & 0.26 & 4.16 & 1.12 \\
\hline 24 & 13.9 & 7.35 & 0.42 & 0.803 & 0.046 & 0.037 & 0.002 & 8.19 & 0.47 & 4.06 & 1.11 \\
\hline 25 & 13.4 & 8.82 & 0.30 & 0.703 & 0.024 & 0.052 & 0.002 & 9.58 & 0.33 & 6.79 & 1.09 \\
\hline 26 & 12.9 & 9.35 & 0.26 & 0.378 & 0.011 & 0.026 & 0.0007 & 9.75 & 0.27 & 10.13 & 1.18 \\
\hline 27 & 12.3 & 10.10 & 0.45 & 0.130 & 0.006 & 0.0035 & 0.0002 & 10.23 & 0.46 & 9.77 & 1.09 \\
\hline 28 & 11.7 & 9.79 & 0.13 & 0.047 & 0.0006 & 0.0010 & 0.00001 & 9.84 & 0.13 & 9.17 & 1.01 \\
\hline 29 & 11.2 & 9.89 & 0.38 & 0.011 & 0.0004 & 0.0005 & 0.00002 & 9.90 & 0.38 & 9.61 & 1.07 \\
\hline 30 & 10.8 & 9.23 & 0.13 & 0.0078 & 0.0001 & 0.0004 & 0.000006 & 9.24 & 0.13 & 9.20 & 1.40 \\
\hline Total_ & 394.60 & 357.71 & \pm 2.77 & 36.43 & \pm 0.40 & 9.98 & \pm 0.11 & 404.18 & \pm 3.16 & 404.79 & \pm 7.14 \\
\hline Mean $\bar{X}, \bar{S}_{x}$ & 13.15 & 11.91 & \pm 0.51 & 1.21 & \pm 0.07 & 0.33 & \pm 0.019 & 13.47 & \pm 0.58 & \pm 13.49 & \pm 1.30 \\
\hline $\mathrm{RMS}, \mathrm{S}_{\overline{\mathrm{x}}}$ & \pm 2.43 & \pm 5.48 & \pm 0.09 & \pm 1.10 & \pm 0.013 & \pm 0.29 & \pm 0.004 & \pm 5.94 & \pm 0.11 & \pm 6.78 & \pm 0.24 \\
\hline
\end{tabular}

(a) Standard deviation $/ \sqrt{6}$, where 6 is the number of scans taken on each compact.

(b) Error assumed to be the same fractional error reported on compact scans. 
TABLE 13

E01-1 COMPARISON OF. CALCULATED AND MEASURED AXIAL Cs-137 INVENTORY

\begin{tabular}{|c|c|c|c|c|c|c|c|c|c|c|}
\hline \multirow{3}{*}{$\begin{array}{l}\text { Compact } \\
\text { I.D. }\end{array}$} & \multirow{3}{*}{$\begin{array}{l}\text { Core } \\
\text { Helght } \\
(\mathrm{mm})\end{array}$} & \multicolumn{3}{|c|}{$\begin{array}{c}\text { Cs }-137 \text { Inventory } \\
\text { Per Compact }\end{array}$} & \multirow{2}{*}{\multicolumn{2}{|c|}{$\begin{array}{l}\text { Relative Difference } \\
\qquad(\mathrm{C} / \mathrm{M}-1)=\mathrm{Z}\end{array}$}} & \multirow{2}{*}{\multicolumn{2}{|c|}{ Comparison }} & \multirow{3}{*}{$\begin{array}{l}\text { GAUGE/FEVER } \\
\text { Thermal } \\
\text { Fluence } \\
\left(\mathrm{n} / \mathrm{m}^{2} \times 10^{25}\right) \\
(\mathrm{E}<0.38 \mathrm{aJ})\end{array}$} & \multirow{3}{*}{$\begin{array}{l}\text { Time- } \\
\text { Avg. } \\
\text { SURVEY } \\
\text { Fue1 } \\
\text { Temp. } \\
\left({ }^{\circ} \mathrm{C}\right)\end{array}$} \\
\hline & & \multirow{2}{*}{$\begin{array}{c}\text { Calc., } \\
\text { C } \\
(\%)\end{array}$} & \multirow{2}{*}{$\begin{array}{c}\text { Meas., } \\
\mathrm{M} \\
(\%)\end{array}$} & \multirow{2}{*}{$\mathrm{S}_{\mathrm{M}}(1 \sigma)$} & & & & & & \\
\hline & & & & & 2 & $s_{Z}\left(1_{\sigma}\right)$ & $\mathrm{D}=\mathrm{Z} / \mathrm{S}_{Z}$ & $\mathrm{D}^{2}$ & & \\
\hline 2 & 775 & 9.2 & 20.6 & \pm 2.7 & -0.553 & \pm 0.059 & -9.45 & 89.38 & 2.07 & 632.7 \\
\hline 4 & 927 & 12.5 & 26.2 & \pm 3.3 & -0.523 & \pm 0.060 & -8.70 & 75.72 & 3.01 & 790.6 \\
\hline 6 & 1080 & 15.2 & 28.7 & \pm 3.3 & -0.470 & \pm 0.061 & -7.72 & 59.66 & 3.90 & 905.8 \\
\hline 8 & 1232 & 16.9 & 27.2 & \pm 3.3 & -0.379 & \pm 0.075 & -5.02 & 25.24 & 4.53 & 994.7 \\
\hline 10 & 1384 & 17.8 & 18.2 & \pm 2.5 & -0.022 & \pm 0.134 & -0.16 & 0.03 & 4.85 & 1055.4 \\
\hline 12 & 1537 & 17.9 & 20.9 & \pm 2.7 & -0.144 & \pm 0.111 & -1.29 & 1.68 & 5.01 & 1096.8 \\
\hline 14 & 1689 & 18.3 & 12.5 & \pm 2.1 & 0.464 & \pm 0.246 & 1.89 & 3.56 & 5.09 & 1127.0 \\
\hline 16 & 1842 & 18.3 & 6.8 & \pm 1.5 & 1.691 & \pm 0.594 & 2.85 & 8.13 & 5.09 & 1145.8 \\
\hline .18 & 1994 & 17.9 & 11.1 & \pm 2.1 & 0.613 & \pm 0.305 & 2.01 & 4.03 & 4.96 & 1152.5 \\
\hline 20 & 2146 & 17.4 & 7.4 & \pm 1.6 & 1.351 & \pm 0.508 & 2.66 & 7.07 & 4.68 & 1151.1 \\
\hline 22 & 2299 & 16.2 & 5.4 & \pm 1.3 & 2.000 & \pm 0.722 & 2.77 & 7.67 & 4.27 & 1135.8 \\
\hline 24 & 2451 & 14.8 & 8.4 & \pm 1.6 & 0.762 & \pm 0.336 & 2.27 & 5.15 & 3.78 & 1107.1 \\
\hline 26 & 2604 & 13.0 & 6.2 & \pm 1.5 & 1.097 & \pm 0.507 & 2.16 & 4.67 & 3.18 & 1065.8 \\
\hline 28 & 2756 & 11.2 & 13.8 & \pm 2.3 & -0.188 & \pm 0.135 & -1.39 & 1.94 & 2.61 & 1011.1 \\
\hline 30 & 2908 & 9.8 & 9.3 & \pm 1.6 & 0.054 & \pm 0.181 & 0.30 & 0.09 & 2.20 & 980.7 \\
\hline Mean $\bar{x}, S_{\bar{x}}$ & . & 15.09 & 15.00 & $\pm 0.61^{(b)}$ & & & & & & \\
\hline RMS & & \pm 3.08 & \pm 7.88 & & & & & & & \\
\hline
\end{tabular}

(a) From "0" Ref., Drawing 33-FT-2.

(b) $s_{\overline{\mathbf{x}}}=\left[\frac{1}{\mathrm{n}^{2}} \sum\left(1_{\sigma}\right)^{2}\right]^{1 / 2}$. 
TABLE 14

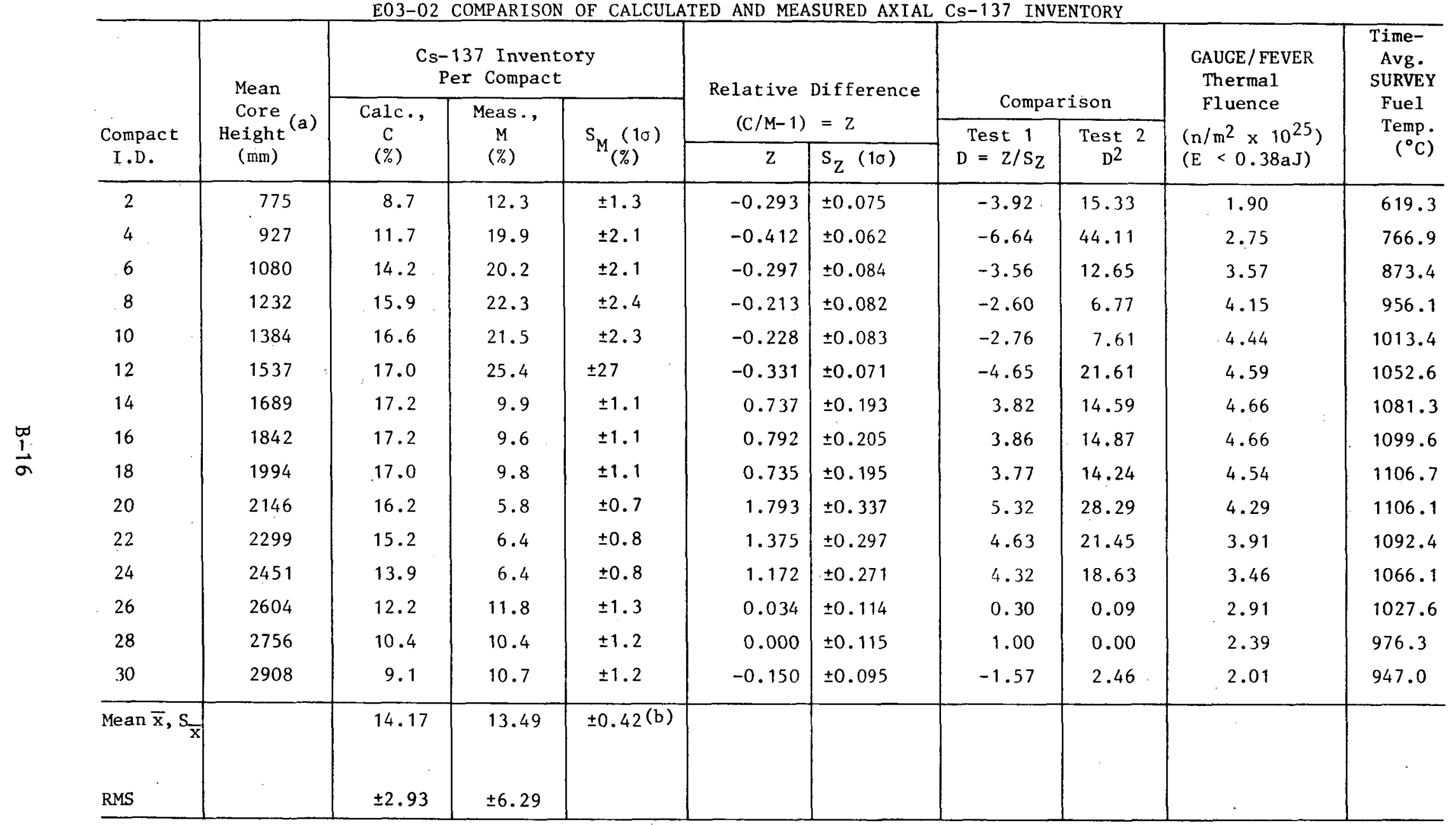

(a) From "0" Ref., Drawing 33-FT-2.

(b) $S_{\bar{x}}=\left[\frac{1}{n^{2}} \sum(1 \sigma)^{2}\right]^{1 / 2}$. 
TABLE 15

E06-02 COMPARISON OF Cs-137 AXIAL INVENTORY

\begin{tabular}{|c|c|c|c|c|c|c|c|c|c|c|}
\hline \multirow{3}{*}{$\begin{array}{l}\text { Compact } \\
\text { I.D. }\end{array}$} & \multirow{3}{*}{$\begin{array}{l}\text { Core } \\
\text { Height } \\
(\mathrm{mm})\end{array}$} & \multicolumn{3}{|c|}{$\begin{array}{l}\text { Cs-137 Inventory } \\
\text { Per Compact }\end{array}$} & \multirow{2}{*}{\multicolumn{2}{|c|}{$\begin{array}{l}\text { Relative Difference } \\
\qquad(\mathrm{C} / \mathrm{M}-1)=\mathrm{Z}\end{array}$}} & \multirow{2}{*}{\multicolumn{2}{|c|}{ Comparison }} & \multirow{3}{*}{$\begin{array}{l}\text { GAUCE/FEVER } \\
\text { Thermal } \\
\text { Fluence } \\
\left(\mathrm{n} / \mathrm{m}^{2} \times 10^{25}\right) \\
(\mathrm{E}<0.38 \mathrm{~J})\end{array}$} & \multirow{3}{*}{$\begin{array}{l}\text { TIne } \\
\text { Avg. } \\
\text { SURVEY } \\
\text { Fuel } \\
\text { Temp. } \\
\left({ }^{\circ} \mathrm{C}\right)\end{array}$} \\
\hline & & \multirow{2}{*}{$\begin{array}{c}\text { Calc., } \\
\text { C } \\
(\%)\end{array}$} & \multirow{2}{*}{$\begin{array}{l}\text { Meas., } \\
M \\
(\%)\end{array}$} & \multirow{2}{*}{$S_{M}\left(1_{\sigma}\right)$} & & & & & & \\
\hline & & & & & 2 & $s_{Z}\left(1_{0}\right)$ & $\begin{array}{l}\text { Test } 1 \\
D=2 / S_{Z}\end{array}$ & $\begin{array}{c}\text { Test }{ }^{2} \\
D^{2}\end{array}$ & & \\
\hline 2 & 775 & 8.9 & 10.1 & \pm 1.5 & -0.109 & \pm 0.132 & -0.08 & 0.68 & 1.95 & 624.9 \\
\hline 4 & 927 & 11.9 & 11.8 & \pm 1.8 & 0.008 & \pm 0.154 & 0.06 & 0.00 & 2.83 & 774.7 \\
\hline 6 & 1080 & 14.5 & 23.5 & \pm 2.9 & -0.383 & +0.076 & -5.03 & 25.30 & 3.67 & 899.5 \\
\hline 8 & 1232 & 16.1 & 25.5 & \pm 3.2 & -0.369 & \pm 0.079 & -4.66 & 21.65 & 4.26 & 960.2 \\
\hline 10 & 1384 & 16.9 & 22.8 & \pm 2.8 & -0.259 & \pm 0.091 & -2.84 & 8.08 & 4.56 & 1017.1 \\
\hline 12 & 1537 & 17.3 & 20.5 & \pm 2.7 & -0.156 & \pm 0.111 & -1.40 & 1.97 & 4.71 & 1056.6 \\
\hline 14 & 1689 & 17.5 & 14.8 & \pm 2.1 & 0.182 & \pm 0.170 & 1.09 & 1.18 & 4.79 & 1086.3 \\
\hline 16 & 1842 & 17.5 & 10.7 & \pm 1.8 & 0.636 & \pm 0.275 & 2.31 & 5.34 & 4.78 & 1105.8 \\
\hline 18 & 1994 & 17.2 & 7.4 & \pm 1.5 & 1.324 & \pm 0.471 & 2.81 & 7.90 & 4.66 & 1114.4 \\
\hline 20 & 2146 & 16.6 & 7.6 & \pm 1.3 & 1.184 & \pm 0.374 & 3.17 & 12.05 & 4.40 & 1115.2 \\
\hline 22 & 2299 & 15.4 & 7.4 & \pm 1.4 & 1.081 & \pm 0.394 & 2.75 & 7.54 & 4.01 & 1102.7 \\
\hline 24 & 2451 & 14.2 & 5.2 & \pm 1.1 & 1.731 & \pm 0.578 & 3.00 & 8.98 & 3.55 & 1077.1 \\
\hline 26 & 2604 & 12.5 & 7.6 & \pm 1.6 & 0.645 & \pm 0.281 & 2.29 & 5.25 & 2.99 & 1040.1 \\
\hline 28 & 2756 & 10.6 & 8.7 & \pm 1.4 & 0.218 & \pm 0.196 & 1.11 & 1.24 & 2.45 & 989.2 \\
\hline 30 & 2908 & 9.3 & 7.9 & \pm 1.4 & 0.177 & \pm 0.209 & 0.85 & 0.72 & 2.07 & 960.0 \\
\hline $\operatorname{Mean} \bar{x}, s_{\bar{x}}$ & & 14.43 & 12.77 & $\pm 0.52^{(b)}$ & & & & & & \\
\hline RMS & & \pm 2.96 & \pm 6.65 & & & & & & & \\
\hline
\end{tabular}

(a) From "0" Ref., Drawing 33-FT-2.

(b) $\mathrm{s}_{\overline{\mathrm{x}}}=\left[\frac{1}{\mathrm{n}^{2}} \sum(1 \sigma)^{2}\right]^{1 / 2}$. 
TABLE 16

E09-01 COMPARISON OF MEASURED AND CALCULATED Cs-137 AXIAL INVENTORY

\begin{tabular}{|c|c|c|c|c|c|c|c|c|c|c|}
\hline \multirow{3}{*}{$\begin{array}{l}\text { Compact } \\
\text { I.D. }\end{array}$} & \multirow{3}{*}{$\mid \begin{array}{c}\text { Core } \\
\text { Height } \\
(\mathrm{mm})\end{array}$} & \multicolumn{3}{|c|}{$\begin{array}{l}\text { Cs-137 Inventory } \\
\text { Per Compact }\end{array}$} & \multirow{2}{*}{\multicolumn{2}{|c|}{$\begin{array}{l}\text { Relative Difference } \\
\qquad(\mathrm{C} / \mathrm{M}-1)=\mathrm{Z}\end{array}$}} & \multicolumn{2}{|c|}{ Comparison } & \multirow{3}{*}{$\begin{array}{l}\text { GAUGE/FEVER } \\
\text { Thermal } \\
\text { Fluence } \\
\left(\mathrm{n} / \mathrm{m}^{2} \times 10^{25}\right) \\
(\mathrm{E}<0.38 \mathrm{aJ})\end{array}$} & \multirow{3}{*}{$\begin{array}{l}\text { Time } \\
\text { Avg. } \\
\text { SURVEY } \\
\text { Fuel } \\
\text { Temp. } \\
\left({ }^{\circ} \mathrm{C}\right)\end{array}$} \\
\hline & & \multirow{2}{*}{$\begin{array}{c}\text { Calc.. } \\
\text { C } \\
(\%)\end{array}$} & \multirow{2}{*}{$\begin{array}{c}\text { Meas., } \\
\text { M } \\
(\%)\end{array}$} & \multirow{2}{*}{$\underset{(\%)}{\mathrm{S}_{\mathrm{M}}(1 \sigma)}$} & & & \multirow{2}{*}{$\begin{array}{l}\text { Test } 1 \\
\mathrm{D}=\mathrm{Z} / \mathrm{S}_{\mathrm{Z}}\end{array}$} & \multirow{2}{*}{$\begin{array}{c}\text { Test } \\
D^{2}\end{array}$} & & \\
\hline & & & & & $\mathrm{Z}$ & $S_{Z}(1 \sigma)$ & & & & \\
\hline 2 & 775 & 8.0 & 9.5 & \pm 1.4 & -0.158 & \pm 0.124 & -1.27 & 1.62 & 1.72 & 579.4 \\
\hline 4 & 927 & 10.3 & 12.9 & \pm 1.7 & -0.202 & \pm 0.105 & -1.92 & 3.67 & 2.34 & 669.0 \\
\hline 6 & 1080 & 12.3 & 20.1 & \pm 2.5 & -0.388 & \pm 0.076 & -5.10 & 26.00 & 2.94 & 739.7 \\
\hline 8 & 1232 & 13.8 & 24.6 & \pm 2.9 & -0.439 & \pm 0.066 & -6.64 & 44.07 & 3.42 & 803.3 \\
\hline 10 & 1384 & 14.6 & 18.8 & \pm 2.3 & -0.223 & \pm 0.095 & -2.35 & 5.53 & 3.69 & 856.3 \\
\hline 12 & 1537 & 15.2 & 18.3 & \pm 2.4 & -0.169 & \pm 0.109 & -1.56 & 2.42 & 3.92 & 912.0 \\
\hline 14 & 1689 & 15.8 & 13.1 & \pm 1.9 & 0.206 & \pm 0.175 & 1.18 & 1.39 & 4.12 & 970.1 \\
\hline 16 & 1842 & 16.2 & 13.2 & \pm 1.9 & 0.227 & \pm 0.177 & 1.29 & 1.66 & 4.25 & 1014.0 \\
\hline 18 & 1994 & 16.2 & 10.5 & \pm 1.7 & 0.543 & \pm 0.250 & 2.17 & 4.72 & 4.27 & 1049.8 \\
\hline 20 & 2149 & 16.0 & 6.9 & \pm 1.3 & 1.319 & \pm 0.437 & 3.02 & 9.11 & 4.20 & 1076.2 \\
\hline 22 & 2299 & 15.6 & 8.1 & \pm 1.7 & 0.926 & \pm 0.404 & 2.29 & 5.25 & 4.05 & 1102.6 \\
\hline 24 & 2451 & 15.1 & 6.4 & \pm 1.5 & 1.360 & \pm 0.553 & 2.46 & 6.04 & 3.87 & 1119.4 \\
\hline 26 & 2604 & 14.6 & 10.1 & \pm 1.7 & 0.446 & \pm 0.243 & 1.83 & 3.35 & 3.71 & 1099.3 \\
\hline 28 & 2756 & 13.6 & 8.8 & \pm 1.5 & 0.545 & \pm 0.263 & 2.07 & 4.29 & 3.39 & 1120.9 \\
\hline 30 & 2908 & 12.9 & 8.7 & \pm 1.7 & 0.483 & \pm 0.290 & 1.07 & 2.78 & 3.16 & 1103.8 \\
\hline $\begin{array}{l}\text { Mean } \bar{x}, S_{\bar{x}} \\
\text { RMS }\end{array}$ & & $\begin{array}{l}14.01 \\
\pm 2.26\end{array}$ & $\begin{array}{l}12.67 \\
\pm 5.25\end{array}$ & $\pm 0.50(\mathrm{~b})$ & & & & & & \\
\hline
\end{tabular}

(a) From "0" Ref., Drawing 33-FT-2.

(b) $s_{\bar{x}}=\left[\frac{1}{n^{2}} \sum(1 \sigma)^{2}\right]^{1 / 2}$ 
TABLE 17

E11-01 COMPARISON OF Cs-137 AXIAL INVENTORY

\begin{tabular}{|c|c|c|c|c|c|c|c|c|c|c|}
\hline \multirow{3}{*}{$\begin{array}{l}\text { Compact } \\
\text { I.D. }\end{array}$} & \multirow{3}{*}{$\begin{array}{l}\text { Core } \\
\text { Helght } \\
\text { (mm) }\end{array}$} & \multicolumn{3}{|c|}{$\begin{array}{l}\text { Cs-137 Inventory } \\
\text { Per Compact }\end{array}$} & \multirow{2}{*}{\multicolumn{2}{|c|}{$\begin{array}{l}\text { Relative Difference } \\
\qquad(\mathrm{C} / \mathrm{M}-1)=2\end{array}$}} & \multicolumn{2}{|c|}{ Comparison } & \multirow{3}{*}{$\begin{array}{c}\text { GAUGE/FEVER } \\
\text { Thermal } \\
\text { Fluence } \\
\left(\mathrm{n} / \mathrm{m}^{2} \times 10^{25}\right) \\
(\mathrm{E}<0.38 \mathrm{aJ})\end{array}$} & \multirow{3}{*}{$\begin{array}{l}\text { Time- } \\
\text { Avg. } \\
\text { SURVEY } \\
\text { Fuel } \\
\text { Temp. } \\
\left({ }^{\circ} \mathrm{C}\right)\end{array}$} \\
\hline & & \multirow{2}{*}{$\begin{array}{c}\text { Calc., } \\
\text { C } \\
(\%)\end{array}$} & \multirow{2}{*}{$\begin{array}{c}\text { Meas, } \\
\mathbf{M} \\
(\%)\end{array}$} & \multirow{2}{*}{$\underset{(\%)}{\mathrm{S}_{M}(1 \sigma)}$} & & & \multirow{2}{*}{$\begin{array}{l}\text { Test } 1 \\
\mathrm{D}=2 / \mathrm{s}_{Z}\end{array}$} & \multirow{2}{*}{$\begin{array}{r}\text { Test } \\
D^{2}\end{array}$} & & \\
\hline & & & & & $\mathrm{z}$ & $S_{Z}(1 \sigma)$ & & & & \\
\hline 2 & 775 & 9.2 & 11.9 & \pm 1.7 & -0.227 & \pm 0.110 & -2.03 & 4.22 & 2.08 & 627.2 \\
\hline 4 & 927 & 12.5 & 16.4 & \pm 2.1 & -0.238 & \pm 0.098 & -2.44 & 5.94 & 3.02 & 782.4 \\
\hline 6 & 1080 & 15.2 & 18.4 & \pm 2.3 & -0.174 & \pm 0.103 & -1.68 & 2.84 & 3.92 & 895.4 \\
\hline 8 & 1232 & 16.9 & 25.3 & \pm 3.1 & -0.332 & \pm 0.082 & -4.06 & 16.46 & 4.56 & 982.7 \\
\hline 10 & 1384 & 17.8 & 19.6 & \pm 2.5 & -0.092 & \pm 0.116 & -0.79 & 0.63 & 4.88 & 1042.9 \\
\hline 12 & 1537 & 17.9 & 21.3 & \pm 2.7 & -0.160 & \pm 0.107 & -1.50 & 2.25 & 5.04 & 1083.9 \\
\hline 14 & 1689 & 18.3 & 14.7 & \pm 1.9 & 0.245 & \pm 0.161 & 1.52 & 2.32 & 5.12 & 1114.0 \\
\hline 16 & 1842 & 18.3 & 14.6 & \pm 2.0 & 0.253 & \pm 0.172 & 1.48 & 2.18 & 5.12 & 1132.9 \\
\hline 18 & 1994 & 17.9 & 11.4 & \pm 1.8 & 0.570 & \pm 0.248 & 2.30 & 5.29 & 4.99 & 1139.3 \\
\hline 20 & 2146 & 17.4 & 13.3 & \pm 1.8 & 0.308 & \pm 0.177 & 1.74 & 3.03 & 4.71 & 1130.7 \\
\hline 22 & 2299 & 16.2 & 11.5 & \pm 1.9 & 0.409 & \pm 0.233 & 1.756 & 3.08 & 4.29 & 1122.1 \\
\hline 24 & 2451 & 14.8 & 12.1 & \pm 1.8 & 0.223 & \pm 0.182 & 1.226 & 1.50 & 3.80 & 1093.4 \\
\hline 26 & 2604 & 13.2 & 15.6 & \pm 2.6 & -0.154 & \pm 0.141 & -1.09 & 1.19 & 3.20 & 1052.0 \\
\hline 28 & 2756 & 11.2 & 13.2 & \pm 2.1 & -0.152 & \pm 0.135 & -1.12 & 1.26 & 2.62 & 998.0 \\
\hline 30 & 2908 & 9.8 & 10.1 & \pm 1.5 & -0.030 & \pm 0.144 & -0.20 & 0.04 & 2.21 & 968.1 \\
\hline $\begin{array}{l}\text { Mean } \bar{x}, S_{\bar{x}} \\
\operatorname{RMS}\end{array}$ & & $\begin{array}{l}15.11 \\
\pm 3.07\end{array}$ & $\begin{array}{r}15.29 \\
\pm 4.11\end{array}$ & $\pm 0.56^{(b)}$ & & & & & & \\
\hline
\end{tabular}

(a) From "0" Ref., Drawing 33-FT-2.

(b) $S_{\bar{x}}=\left[\frac{1}{n^{2}} \sum(1 \sigma)^{2}\right]^{1 / 2}$. 
TABLE 18

E14-01 COMPARISON OF MEASURED AND CALCULATED Cs-137 AXIAL INVENTORY

\begin{tabular}{|c|c|c|c|c|c|c|c|c|c|c|}
\hline \multirow{3}{*}{$\begin{array}{l}\text { Compact } \\
\text { I.D. }\end{array}$} & \multirow{3}{*}{$\begin{array}{l}\text { Core } \\
\text { Height } \\
(\mathrm{m}) \\
(\mathrm{mm})\end{array}$} & \multicolumn{3}{|c|}{$\begin{array}{l}\text { Cs-137 Inventory } \\
\text { Per Compact }\end{array}$} & \multirow{2}{*}{\multicolumn{2}{|c|}{$\begin{array}{l}\text { Relative Difference } \\
\qquad(\mathrm{C} / \mathrm{M}-1)=\mathrm{Z}\end{array}$}} & \multicolumn{2}{|c|}{ Comparison } & \multirow{3}{*}{$\begin{array}{c}\text { GAUGE/FEVER } \\
\text { Therma1 } \\
\text { Fluence } \\
\left(\mathrm{n} / \mathrm{m}^{2} \times 10^{25}\right) \\
(\mathrm{E}<0.38 \mathrm{aJ})\end{array}$} & \multirow{3}{*}{$\begin{array}{l}\text { Time- } \\
\text { Avg. } \\
\text { SURVEY } \\
\text { Fue1 } \\
\text { Temp. } \\
\left({ }^{\circ} \mathrm{C}\right)\end{array}$} \\
\hline & & \multirow{2}{*}{$\begin{array}{c}\text { Calc., } \\
\text { C } \\
(\%)\end{array}$} & \multirow{2}{*}{$\begin{array}{c}\text { Meas., } \\
\underset{(\%)}{(\%)}\end{array}$} & \multirow{2}{*}{$\underset{(\%)}{S_{M}(1 \sigma)}$} & & & \multirow{2}{*}{$\begin{array}{l}\text { Test } 1 \\
D=Z / S_{Z}\end{array}$} & \multirow{2}{*}{$\begin{array}{c}\text { Test } \\
\mathrm{D}^{2}\end{array}$} & & \\
\hline & & & & & $\mathrm{Z}$ & $S_{Z}(1 \sigma)$ & & & & \\
\hline 2 & 775 & 9.1 & 10.9 & \pm 1.6 & -0.165 & \pm 0.123 & 1.35 & 1.82 & 2.02 & 598.8 \\
\hline 4 & 927 & 12.3 & 9.8 & \pm 1.5 & 0.255 & \pm 0.192 & 1.33 & 1.76 & 2.93 & 734.8 \\
\hline 6 & 1080 & 14.8 & 12.8 & \pm 1.8 & 0.156 & \pm 0.163 & 0.96 & 0.92 & 3.80 & 833.6 \\
\hline 8 & 1232 & 16.6 & 15.6 & \pm 2.0 & 0.064 & \pm 0.136 & 0.47 & 0.22 & 4.41 & 913.3 \\
\hline 10 & 1384 & 17.4 & 14.4 & \pm 1.9 & 0.208 & \pm 0.159 & 1.31 & 1.71 & 4.72 & 970.1 \\
\hline 12 & 1537 & 17.8 & 15.8 & \pm 2.2 & 0.127 & \pm 0.157 & 0.81 & 0.65 & 4.88 & 1009.3 \\
\hline 14 & 1689 & 18.0 & 17.9 & \pm 2.2 & 0.006 & \pm 0.124 & 0.05 & 0.00 & 4.96 & 1038.1 \\
\hline 16 & 1842 & 18.0 & 17.6 & \pm 2.2 & 0.023 & \pm 0.128 & 0.18 & 0.03 & 4.96 & 1056.1 \\
\hline 18 & 1994 & 17.6 & 17.2 & \pm 2.2 & 0.023 & \pm 0.131 & 0.18 & 0.03 & 4.83 & 1062.4 \\
\hline 20 & 2146 & 17.0 & 14.9 & \pm 1.9 & 0.141 & \pm 0.145 & 0.97 & 0.94 & 4.56 & 1054.8 \\
\hline 22 & 2299 & 15.9 & 16.5 & \pm 2.2 & -0.040 & \pm 0.128 & 0.28 & 0.08 & 4.15 & 1047.2 \\
\hline 24 & 2451 & 14.6 & 13.7 & \pm 1.9 & 0.070 & \pm 0.148 & 0.44 & 0.20 & 3.68 & 1020.9 \\
\hline 26 & 2604 & 12.8 & 11.9 & \pm 1.8 & 0.076 & \pm 0.163 & 0.47 & 0.22 & 3.10 & 983.6 \\
\hline 28 & 2756 & 10.9 & 10.0 & \pm 1.6 & 0.090 & \pm 0.174 & 0.52 & 0.27 & 2.54 & 935.6 \\
\hline 30 & 2908 & 9.5 & 8.1 & \pm 1.3 & 0.173 & \pm 0.188 & 0.92 & 0.84 & 2.14 & 911.6 \\
\hline $\begin{array}{c}\text { Mean } \bar{x}, S_{\bar{x}} \\
\text { RMS }\end{array}$ & & $\begin{array}{l}14.82 \\
\pm 3.05\end{array}$ & $\begin{array}{l}13.81 \\
\pm 2.99\end{array}$ & $\pm 0.49^{(b)}$ & & & & & & \\
\hline
\end{tabular}

(a) From "0" Ref., Drawing 33-FT-2.

(b) $s_{\bar{x}}=\left[\frac{1}{n^{2}} \sum(1 \sigma)^{2}\right]^{1 / 2}$. 
TABL:F 19

SURVEY TEMPERATURE PREDICTIONS FOR PEACH BOTTOM DRIVER ELEMENTS

\begin{tabular}{|c|c|c|c|c|c|c|c|c|c|c|c|c|c|c|c|c|c|c|}
\hline \multirow[b]{2}{*}{$\begin{array}{l}\text { Element } \\
\text { I.D. }\end{array}$} & \multirow{2}{*}{$\begin{array}{l}\text { GAUCE } \\
\text { Location } \\
\text { (Patch/ } \\
\text { Column) }\end{array}$} & \multicolumn{5}{|c|}{ Predicted } & \multirow{2}{*}{$\frac{12}{12}$} & \multirow{2}{*}{$\frac{14}{14}$} & \multirow{2}{*}{$-\frac{-A v e r a g}{16}$} & \multirow{2}{*}{\multicolumn{2}{|c|}{\begin{tabular}{|c|c} 
d & Temperatures for \\
18 & 20
\end{tabular}}} & \multicolumn{4}{|c|}{ Even-Numbered Fuel Compacts $\left({ }^{\circ} \mathrm{C}\right)$} & \multirow[b]{2}{*}{\begin{tabular}{|r|} 
Top \\
30
\end{tabular}} & \multirow[b]{2}{*}{$\bar{x}$} & \multirow[b]{2}{*}{ RMS $^{(A)}$} \\
\hline & & $\begin{array}{c}\text { Bottom } \\
2\end{array}$ & 4 & 6 & 8 & 10 & & & & & & 22 & 24 & 26 & 28 & & & \\
\hline F0 $1-01$ & $1 / 2$ & 632 & 790 & 905 & 994 & 105.5 & 1097 & 1127 & 1146 & 1152 & 1151 & 1136 & 1106 & 1065 & 1010 & 980 & 1023 & 126 \\
\hline E01-01 & $1 / 7$ & 632 & 790 & 905 & 994 & 1055 & 1096 & 1127 & 1145 & 1152 & 1151 & 1135 & 1107 & 1065 & 1011 & 980 & 1023 & $\begin{array}{l}126 \\
127\end{array}$ \\
\hline E03-02 & $2 / 1$ & 619 & 767 & 873 & 956 & 1013 & 1052 & 1081 & 1099 & 1106 & 1106 & 1092 & 1066 & 1027 & 976 & 947 & 985 & 118 \\
\hline E02-02 & $2 / 4$ & 626 & 780 & 892 & 979 & 1038 & 1079 & 1108 & 1126 & 1133 & 1132 & 1117 & 1089 & 1048 & 995 & 965 & 1007 & 123 \\
\hline E03-01 & $2 / 6$ & 611 & 752 & 851 & 928 & 982 & 1020 & 1048 & 1066 & 1075 & 1075 & 1064 & 1040 & 10014 & 956 & 927. & 960 & 111 \\
\hline $\begin{array}{l}E 04-02 \\
F 03-02\end{array}$ & $\begin{array}{l}2 / 7 \\
3 / 1\end{array}$ & 610 & 750 & 848 & 924 & 978 & 1015 & 1044 & 1062 & 1070 & 1071 & 1059 & 1036 & 1000 & 952 & 924 & 956 & 110 \\
\hline $\begin{array}{l}\mathrm{F03}-02 \\
\mathrm{~F} 04-03\end{array}$ & $\begin{array}{l}3 / 1 \\
3 / 2\end{array}$ & $\begin{array}{l}616 \\
617\end{array}$ & $\begin{array}{l}764 \\
765\end{array}$ & $\begin{array}{l}873 \\
872\end{array}$ & $\begin{array}{l}958 \\
955\end{array}$ & $\begin{array}{l}1016 \\
1013\end{array}$ & \begin{tabular}{|l}
1056 \\
1052
\end{tabular} & $\begin{array}{l}1084 \\
1081\end{array}$ & \begin{tabular}{|l|l|}
1102 \\
1094
\end{tabular} & $\begin{array}{l}1108 \\
1105\end{array}$ & $\begin{array}{l}11116 \\
1104\end{array}$ & $\mid 1091$ & 1064 & 1024 & 972 & 942 & 985 & 119 \\
\hline F02-01 & $3 / 5$ & 621 & 772 & \begin{tabular}{|l|l}
812 \\
883
\end{tabular} & $\begin{array}{l}958 \\
970\end{array}$ & 1029 & $\begin{array}{l}1072 \\
1069\end{array}$ & 1098 & 1116 & 1122 & $\begin{array}{l}1104 \\
1120\end{array}$ & $\begin{array}{l}1090 \\
1103\end{array}$ & $\begin{array}{l}1063 \\
1077\end{array}$ & $\begin{array}{l}1024 \\
1036\end{array}$ & $\begin{array}{l}973 \\
983\end{array}$ & $\begin{array}{l}943 \\
953\end{array}$ & $\begin{array}{l}984 \\
997\end{array}$ & 122 \\
\hline $103-01$ & $3 / 6$ & 576 & 693 & 786 & 866 & 926 & $9 / 4$ & 1016 & 1064 & 101,2 & 1074 & 1071 & 1055 & 1031 & 992 & 971 & 940 & 128 \\
\hline $104-03$ & $4 / 2$ & 618 & 767 & 874 & 958 & 1016 & 1055 & 1084 & 1102 & 1109 & 1108 & 1093 & 1066 & 1027 & 976 & $94 \mathrm{~K}$ & 987 & 124 \\
\hline $\mathrm{B} 03-03$ & $5 / 3$ & 619 & 768 & 875 & 958 & 1016 & 1055 & 1084 & 1802 & 1109 & 1108 & 1094 & 1067 & 1028 & 977 & 347 & 987 & 118 \\
\hline B02-02 & $5 / 4$ & 627 & 781 & 894 & 981 & 1041 & 1082 & 1111 & 1129 & 1130 & 1134 & 1119 & 1091 & 1050 & 996 & 966 & 1010 & 124 \\
\hline B02-01 & $5 / 5$ & 624 & $\begin{array}{l}777 \\
697\end{array}$ & 889 & 976 & 1036 & 1076 & 1105 & 1124 & 1130 & 1128 & 1113 & 1084 & 1043 & 990 & 959 & 1004 & 123 \\
\hline $\mathrm{HO3}-01$ & $\begin{array}{l}5 / 6 \\
8 / 5\end{array}$ & $\begin{array}{l}579 \\
613\end{array}$ & $\begin{array}{l}697 \\
755\end{array}$ & $\begin{array}{l}791 \\
853\end{array}$ & 873 & $\begin{array}{l}933 \\
983\end{array}$ & $\begin{array}{r}982 \\
1020\end{array}$ & 1023 & 1052 & 1070 & 1082 & 1079 & 1063 & 1038 & 999 & 977 & 94.9 & 129 \\
\hline $\begin{array}{l}1: 05-02 \\
: 06-02\end{array}$ & $\begin{array}{l}8 / 5 \\
8 / 6\end{array}$ & $\begin{array}{l}613 \\
624\end{array}$ & 774 & $\begin{array}{l}833 \\
879\end{array}$ & $\begin{array}{l}929 \\
960\end{array}$ & $\begin{array}{r}983 \\
1017\end{array}$ & $\begin{array}{l}1020 \\
1056\end{array}$ & $10 \% 9$ & 1068 & 1077 & 1078 & 1067 & 1043 & 1008 & 960 & 931 & $9+2$ & 111 \\
\hline $\begin{array}{l}500-02 \\
\text { F05-05 }\end{array}$ & $11 / 1$ & $\begin{array}{l}024 \\
615\end{array}$ & 758 & 858 & 935 & 990 & $\begin{array}{l}1056 \\
1028\end{array}$ & $\begin{array}{l}1086 \\
1057\end{array}$ & $\begin{array}{l}1105 \\
1076\end{array}$ & 1114 & 1115 & 1102 & 1077 & 1040 & 989 & $\begin{array}{l}960 \\
936\end{array}$ & & 118 \\
\hline F05-04 & $11 / 6$ & 623 & 773 & 881 & 964 & 1022 & 1068 & 1090 & & $\begin{array}{l}1086 \\
1116\end{array}$ & $\begin{array}{l}1085 \\
1116\end{array}$ & $\begin{array}{l}1073 \\
1102\end{array}$ & $\begin{array}{l}1049 \\
1076\end{array}$ & $\begin{array}{l}1013 \\
1037\end{array}$ & $\begin{array}{l}964 \\
985\end{array}$ & $\begin{array}{l}936 \\
955\end{array}$ & $\begin{array}{l}968 \\
994\end{array}$ & $\begin{array}{l}113 \\
119\end{array}$ \\
\hline A05-05 & $13 / 1$ & 579 & 697 & 790 & 872 & 927 & 980 & 1022 & 1051 & 1069 & 1081 & 1074 & $\begin{array}{l}1076 \\
106,3\end{array}$ & $\begin{array}{l}1037 \\
1039\end{array}$ & $\begin{array}{r}985 \\
1000\end{array}$ & 978 & 949 & $\begin{array}{l}119 \\
129\end{array}$ \\
\hline BOS-01 & $13 / 3$ & 576 & 692 & 783 & 862 & 921 & 969 & 1010 & 1039 & 1056 & 1069 & 1067 & 1052 & $\begin{array}{r}1029 \\
1029\end{array}$ & 991 & 970 & 939 & $\begin{array}{l}129 \\
127\end{array}$ \\
\hline $104-04$ & $13 / 5$ & 578 & 696 & 790 & 871 & 931 & 980 & 1021 & 1050 & $106 \mathrm{fig}$ & 1080 & 1077 & 1062 & 1037 & 998 & 976 & 948 & 129 \\
\hline $305-02$ & $14 / 5$ & 579 & 697 & 791 & 873 & 933 & 982 & 1023 & 1052 & 1070 & 1082 & 1080 & 10665 & 1040 & 1001 & 979 & 950 & 130 \\
\hline E05-01 & $19 / 3$ & 612 & 752 & 848 & 922 & 976 & 1013 & 1012 & 1061 & 1071 & 1072 & 1062 & 1039 & 1005 & 957 & 928 & 957 & 110 \\
\hline E07-01 & $37 / 1$ & 578 & 669 & 739 & 802 & 855 & 910 & 968 & 1012 & 1048 & 1079 & 1101 & 1117 & 1135 & 1117 & 1100 & 949 & 158 \\
\hline E.08-02 & $37 / 3$ & 577 & 668 & 738 & 801 & 853 & 909 & 967 & 1011 & 1046 & 1077 & 1099 & 1115 & 1133 & 1115 & 1098 & 947 & 158 \\
\hline $807-02$ & $37 / 4$ & 624 & 774 & 878 & 959 & 1015 & 1055 & 1085 & 1106 & 1113 & 1114 & 1102 & 1077 & 1039 & 989 & 959 & 993 & 118 \\
\hline F11-03 & $41 / 3$ & 632 & 792 & 909 & 998 & 1059 & 1100 & 1130 & 1148 & 1155 & $1145^{(b)}$ & 1136 & 1107 & 1064 & 1009 & 977 & 1024 & 127 \\
\hline F10-09 & $44 / 1$ & 632 & 791 & \begin{tabular}{|l}
709 \\
904
\end{tabular} & 991 & 1051 & 1092 & 1122 & 1141 & 114.8 & $1140^{(\mathrm{b})}$ & 1132 & 1103 & 1062 & 1008 & 976 & 1019 & 125 \\
\hline F09-08 & $44 / 5$ & 633 & 790 & 903 & 989 & 1048 & 1089 & 1119 & 1139 & 1146 & $1139^{(b)}$ & 1131 & 1103 & 1063 & 1009 & 978 & 1018 & 124 \\
\hline B $111-0\}$ & $49 / 3$ & 634 & 795 & 913 & 1003 & 1065 & 1106 & 1136 & 1155 & 1161 & $1151^{(b)}$ & 1142 & 1111 & 1068 & 1012 & 980 & 1029 & 128 \\
\hline E 10-02 & $61 / 1$ & 623 & 789 & 880 & 963 & 1021 & 1061 & 1090 & 1109 & 1117 & $1110^{(b)}$ & 1103 & 1078 & 1038 & 98 & 956 & 995 & 118 \\
\hline E11-02 & $61 / 2$ & 626 & 780 & 892 & 978 & 1037 & 1077 & 1107 & 1126 & 1133 & $1125^{(b)}$ & 1117 & 1088 & 1047 & 994 & 964 & 1006 & 123 \\
\hline 809-02 & $61 / 5$ & 577 & 667 & \begin{tabular}{|l|l|} 
& \\
737
\end{tabular} & 800 & 853 & \begin{tabular}{|l|l}
008 \\
\end{tabular} & 966 & 1010 & 1046 & $1072^{(b)}$ & 1098 & 1114 & 1133 & 1115 & 1098 & 946 & 157 \\
\hline E09-01 & $61 / 6$ & 578 & 669 & 739 & 803 & 856 & 912 & 970 & 1014 & 1049 & $1076^{(\mathrm{b})}$ & 1102 & 1119 & 1138 & 1120 & 1103 & 950 & 159 \\
\hline F12-11 & $70 / 6$ & 631 & $\begin{array}{l}709 \\
790\end{array}$ & \begin{tabular}{|l|l|}
739 \\
907
\end{tabular} & 997 & $\begin{array}{r}050 \\
1057\end{array}$ & 1098 & 1128 & 1146 & 1152 & $1142^{(b)}$ & 1133 & 1103 & $\begin{array}{l}1060 \\
\end{array}$ & 1004 & 973 & 1021 & 126 \\
\hline E11-01 & $90 / 4$ & 627 & 782 & 895 & 982 & 1042 & \begin{tabular}{|l}
1050 \\
1083
\end{tabular} & 1114 & 1132 & 1139 & $1130^{(\mathrm{b})}$ & 1122 & 10 & 1052 & 998 & 968 & 1011 & 124 \\
\hline E12-02 & $91 / 6$ & 622 & 774 & 885 & 972 & 1031 & 1072 & 1101 & 1119 & 1126 & $1117^{(\mathrm{b})}$ & 1108 & 1080 & 1039 & 985 & 95 & 999 & 122 \\
\hline E13-02 & $91 / 7$ & 613 & 7.60 & 869 & 954 & 1013 & 1053 & 1082 & 1100 & 1105 & $1097^{(\mathrm{b})}$ & $\mid 1088$ & 1059 & 1019 & 939 & 938 & 979 & 119 \\
\hline F15-14 & $101 / 3$ & 613 & 761 & 873 & 963 & 1025 & 1067 & 1098 & 1116 & 1121 & $1111^{(\mathrm{b})}$ & 1101 & 1071 & 1029 & 976 & 951 & 992 & 126 \\
\hline F14-13 & $101 / 4$ & 619 & 772 & 887 & 977 & 1039 & 1080 & 1110 & 1127 & 1132 & $1121^{\text {(b) }}$ & 1111 & 1080 & 1037 & 983 & 954 & 1002 & 126 \\
\hline A $17-08$ & $105 / 6$ & 564 & 679 & 761 & 828 & 877 & 912 & 938 & 955 & 961 & 95 & 949 & 927 & 895 & 855 & 837 & 861 & 91 \\
\hline$A 17-11$ & $106 / 7$ & 562 & 677 & 758 & 825 & 874 & 908 & 934 & 950 & 957 & 951 (b) & & 922 & 891 & 851 & 83 & 858. & 92 \\
\hline B14-02 & $108 / 4$ & 616 & 768 & \begin{tabular}{|l|l|}
882 \\
\end{tabular} & 973 & 1036 & 1078 & 1107 & 1124 & 1129 & $\begin{array}{r}931 \\
1118^{(b)}\end{array}$ & \begin{tabular}{|r|}
944 \\
1108
\end{tabular} & 1077 & \begin{tabular}{|l}
1031 \\
1034
\end{tabular} & 980 & 951 & $\begin{array}{l}030 . \\
999\end{array}$ & 125 \\
\hline B13-01 & $108 / 5$ & 622 & 777 & 894 & 986 & 1049 & 1091 & 1120 & 1138 & 1142 & $1132^{(\mathrm{b})}$ & 1121 & 1090 & 1046 & 991 & 962 & 1011 & 127 \\
\hline A14-14 & $108 / 6$ & 615 & 765 & 879 & 969 & 1031 & 1073 & 1102 & 1119 & 1124 & 1114 & 1103 & 1072 & 1030 & 976 & 948 & 995 & 124 \\
\hline E14-01 & $126 / 1$ & 598 & 734 & 833 & 913 & 970 & 1009 & 1038 & 1056 & 1062 & $1054^{(\mathrm{b})}$ & $\begin{array}{l}1047 \\
\end{array}$ & 1020 & 983 & 935 & 911. & .944 & 111 \\
\hline E15-01 & $126 / 2$ & 550 & 658 & \begin{tabular}{|l}
033 \\
733
\end{tabular} & 794 & 839 & \begin{tabular}{|l}
$\quad 872$ \\
\end{tabular} & \begin{tabular}{|r}
8 \\
897
\end{tabular} & 913 & 919 & $915^{\text {(b) }}$ & 910 & \begin{tabular}{|l}
891 \\
\end{tabular} & 863 & 862 & 811 & 826 & 85 \\
\hline E15-02 & $126 / 3$ & 550 & 661 & 737 & 799 & 845 & 877 & 901 & 916 & 922 & 917 (b) & 911 & $\begin{array}{l}891 \\
\end{array}$ & 860 & 822 & 803 & 828 & 85 \\
\hline E14-02 & $126 / 4$ & 600 & 739 & 840 & 922 & 979 & 1018 & 1046 & 1064 & 1070 & $\begin{array}{c}911(\mathrm{~b}) \\
10661^{2}\end{array}$ & 1053 & \begin{tabular}{|l}
090 \\
1025
\end{tabular} & $\begin{array}{l}860 \\
987\end{array}$ & 938 & 912 & $\begin{array}{l}020 \\
950\end{array}$ & 113 \\
\hline E13-01 & $126 / 5$ & 607 & 750 & 855 & 939 & 997 & 1036 & 1065 & 1082 & 1088 & $1080^{(\mathrm{b})}$ & 1071 & 1043 & 1004 & 953 & 925 & 966 & 117 \\
\hline F $16-15$ & $139 / 5$ & 562 & 677 & 759 & 826 & 876 & 911 & 938 & 954 & 961 & $955^{(\mathrm{b})}$ & 949 & 927 & 896 & 857 & 840 & 859 & 94 \\
\hline
\end{tabular}

(a) ${ }_{\text {RMS }}=\left[\frac{1}{n}\left(x_{i}-\bar{x}^{2}\right]^{1 / 2}\right.$.

(b) Interpolated value. 
TABLE 20

POSITION AND MAGNITUDE OF MAXIMUM Cs-137 RELEASE IN DRIVER ELEMENTS

\begin{tabular}{|c|c|c|c|c|c|c|c|c|c|c|c|}
\hline \multirow{3}{*}{$\begin{array}{c}\text { Element } \\
\text { I.D. }\end{array}$} & \multirow{3}{*}{$\begin{array}{c}\text { Axial } \\
\text { Location } \\
(\mathrm{mm})\end{array}$} & \multicolumn{3}{|c|}{$\begin{array}{c}\text { Maximum } \\
\text { Cs-137 Loss }\end{array}$} & \multirow{2}{*}{\multicolumn{2}{|c|}{$\begin{array}{l}\text { Relative D1fference } \\
(\mathrm{C} / \mathrm{M}-1)=\mathrm{Z}\end{array}$}} & \multicolumn{2}{|c|}{ Comparison } & \multirow{3}{*}{$\begin{array}{c}\text { Compact } \\
\text { I.D. }\end{array}$} & \multirow{3}{*}{$\begin{array}{l}\text { GAUGE / FEVER } \\
\text { Thermal } \\
\text { Fluence } \\
\left(\mathrm{n} / \mathrm{m}^{2} \times 10^{25}\right) \\
(\mathrm{E}<0.38 \mathrm{aJ})\end{array}$} & \multirow{3}{*}{$\begin{array}{l}\text { Time- } \\
\text { Avg. } \\
\text { SURVEY } \\
\text { Fue 1 } \\
\text { Temp. } \\
\left({ }^{\circ} \mathrm{C}\right)\end{array}$} \\
\hline & & \multirow{2}{*}{$\begin{array}{c}\text { Calc.. } \\
\text { C } \\
(\%)\end{array}$} & \multirow{2}{*}{$\begin{array}{c}\text { Meas. } \\
M \\
(\%)\end{array}$} & \multirow{2}{*}{$S_{M}(1 \sigma)$} & & & \multirow{2}{*}{$\begin{array}{l}\text { Test } 1 \\
D=Z / S_{Z}\end{array}$} & \multirow{2}{*}{$\begin{array}{c}\text { Test } \\
D^{2}\end{array}$} & & & \\
\hline & & & & & $\mathrm{z}$ & $\mathrm{S}_{z}(1 \sigma)$ & & & & & \\
\hline E03-01 & 1991 & 16.1 & 7.3 & \pm 0.9 & 1.205 & \pm 0.272 & 4.43 & 19.66 & 18 & 4.26 & 1075 \\
\hline E 14-02 & Smooth & Profile & & & & & & & & & \\
\hline E03-02 & 2109 & 16.2 & 5.8 & \pm 0.7 & 1.793 & \pm 0.337 & 5.32 & 28.29 & 20 & 4.29 & 1106 \\
\hline E09-02 & 2000 & 16.0 & 6.4 & \pm 0.7 & 1.500 & \pm 0.273 & 5.49 & 30.01 & 18 & 4.22 & 1046 \\
\hline E04-02 & 1660 & 16.4 & 9.5 & \pm 1.0 & 0.726 & \pm 0.182 & 4.00 & 15.98 & 15 & 4.34 & 1053 \\
\hline E13-02 & Smooth & Profile & & & & & & & & & \\
\hline $\mathrm{E} 05-02$ & 2266 & 14.8 & 5.1 & \pm 0.6 & 1.902 & \pm 0.341 & 5.57 & 31.04 & $21-22$ & 3.78 & 1067 \\
\hline E.12-02 & 2236 & 16.7 & 10.7 & \pm 1.2 & 0.561 & \pm 0.175 & 3.21 & 10.26 & 21 & 4.45 & 1113 \\
\hline $\mathrm{E} 07-02$ & 2248 & 16.2 & 5.8 & \pm 0.7 & 1.793 & \pm 0.337 & 5.32 & 28.29 & 21 & 4.25 & 1109 \\
\hline E $10-02$ & 2333 & 16.2 & 7.4 & \pm 0.8 & 1.189 & \pm 0.237 & 5.02 & 25.25 & 21 & 4.29 & 1107 \\
\hline E.13-01 & 2192 & 16.7 & 11.8 & \pm 1.3 & 0.415 & \pm 0.156 & 2.66 & 7.09 & $20-21$ & 4.46 & 1080 \\
\hline E08-02 & 2511 & 14.8 & 5.4 & \pm 0.6 & 1.741 & \pm 0.304 & 5.72 & 32.68 & 25 & 3.80 & 1125 \\
\hline $\mathrm{A} 04-03$ & 2415 & 13.9 & 5.3 & \pm 0.6 & 1.623 & \pm 0.297 & 5.47 & 29.87 & 24 & 3.44 & 1067 \\
\hline$A 04-04$ & 2070 & 15.6 & 4.6 & \pm 0.5 & 2.391 & \pm 0.368 & 6.49 & 42.08 & 19 & 4.04 & 1074 \\
\hline A14-14 & Smooth & Profile & & & & & & & & & \\
\hline B05-02 & 2106 & 16.8 & 5.3 & \pm 0.6 & 2.170 & \pm 0.359 & 6.05 & 36.56 & 20 & 4.51 & 1083 \\
\hline F03-02 & 2028 & 16.4 & 6.1 & \pm 0.7 & 1.688 & \pm 0.309 & 5.47 & 29.96 & 19 & 4.37 & 1108 \\
\hline F04-03 & 1971 & 16.7 & 5.1 & \pm 0.6 & 2.275 & \pm 0.385 & 5.91 & 34.86 & 18 & 4.48 & 1106 \\
\hline F15-14 & Smooth & Profile & & & & & & & & & \\
\hline B $11-03$ & 2211 & 16.7 & 7.2 & \pm 0.8 & 1.319 & \pm 0.258 & 5.12 & 26.21 & 21 & 4.47 & 1147 \\
\hline F02-81 & 2470 & 14.1 & 5.0 & \pm 0.6 & 1.820 & \pm 0.338 & 5.38 & 28.93 & 24 & 3.53 & 1077 \\
\hline F05-04 & 2014 & 16.8 & 5.5 & \pm 0.6 & 2.055 & \pm 0.333 & 6.17 & 38.02 & 19 & 4.47 & 1117 \\
\hline $\mathrm{B} 02-01$ & 1996 & 17.3 & 6.3 & \pm 0.7 & 1.746 & \pm 0.305 & 5.72 & 32.75 & 18 & 4.68 & 1130 \\
\hline A17-11 & Smooth & Profile & & & & & & & & & \\
\hline E14-01 & Smooth & Profile & & & & & & & & & \\
\hline E01-01 & 1917 & 18.2 & 5.8 & \pm 1.2 & 2.138 & \pm 0.649 & 3.29 & 10.84 & 27 & 5.05 & 1149 \\
\hline E02-02 & 2255 & 16.4 & 4.6 & \pm 1.5 & 2.565 & \pm 1.163 & 2.21 & 4.87 & 21 & 4.33 & 1125 \\
\hline E09-01 & 2379 & 15.4 & 5.2 & \pm 1.2 & 1.962 & \pm 0.683 & 2.87 & 8.24 & 23 & 3.95 & 1111 \\
\hline F11-01 & 2035 & 17.7 & 11.4 & \pm 1.8 & 0.553 & \pm 0.245 & 2.25 & 5.08 & 19 & 4.85 & 1135 \\
\hline F15-01 & Smooth & Profile & & & & & & & & & \\
\hline E07-01 & 1988 & 16.0 & 6.3 & \pm 1.3 & 1.540 & \pm 0.524 & 2.94 & 8.63 & 19 & 4.22 & 1064 \\
\hline E06-02 & 2038 & 16.9 & 7.4 & \pm 1.5 & 1.284 & \pm 0.463 & 2.77 & 7.69 & 19 & 4.54 & 1114 \\
\hline E05-01 & 1979 & 16.0 & 8.2 & \pm 1.6 & 0.951 & \pm 0.381 & 2.50 & 6.24 & 18 & 4.22 & 1071 \\
\hline E15-02 & Smooth & Profile & & & & & & & & & \\
\hline B $13-01$ & 2083 & 17.9 & 11.4 & \pm 2.2 & 0.570 & \pm 0.303 & 1.88 & 3.54 & 19 & 4.94 & 1137 \\
\hline A03-03 & Smooth & Profile & & & & & & & & & \\
\hline B02-02 & 1998 & 17.5 & 4.6 & \pm 1.1 & 2.804 & \pm 0.910 & 3.08 & 9.50 & 18 & 4.77 & 1136 \\
\hline F11-02 & 1979 & 17.7 & 8.0 & \pm 1.3 & 1.213 & \pm 0.360 & 3.37 & 11.37 & 18 & 4.88 & 1133 \\
\hline A05-05 & 2236 & 15.4 & 5.9 & \pm 1.3 & 1.610 & \pm 0.575 & 2.80 & 7.84 & 21 & 3.91 & 1080 \\
\hline B03-01 & 1963 & 15.7 & 7.9 & \pm 1.7 & 0.987 & \pm 0.428 & 2.31 & 5.33 & 18 & 4.09 & 1070 \\
\hline B $14-02$ & 2204 & 17.1 & 11.1 & \pm 1.7 & 0.541 & \pm 0.236 & 2.29 & 5.25 & 21 & 4.62 & 1131 \\
\hline B03-03 & 1914 & 17.1 & 2.7 & \pm 1.0 & 5.333 & \pm 2.346 & 2.27 & 5.16 & 17 & 4.62 & 1106 \\
\hline B05-01 & 1984 & 15.4 & 5.5 & \pm 1.2 & 1.800 & \pm 0.610 & 2.95 & 8.68 & 18 & 3.99 & 1057 \\
\hline F03-01 & 2384 & 14.3 & 4.0 & \pm 1.2 & 2.575 & \pm 0.107 & 2.40 & 5.76 & 23 & 3.60 & 1063 \\
\hline F05-05 & 1730 & 16.6 & 7.5 & \pm 1.4 & 1.213 & \pm 0.413 & 2.94 & 8.62 & 15 & 4.44 & 1066 \\
\hline A $17-08$ & Smooth & Proftle & & & & & & & & & \\
\hline F11-03 & 1770 & 18.2 & 9.0 & \pm 1.3 & 1.022 & \pm 0.292 & 3.50 & 12.24 & 15 & 5.06 & 1113 \\
\hline $\begin{array}{l}\text { Mean } \bar{x} \\
\text { RMS }\end{array}$ & & & & & & & & , & & $\cdot$ & $\begin{array}{r}1110 \\
\pm 29\end{array}$ \\
\hline
\end{tabular}


TABLE 21

POSITION AND MAGNITUDE OF MAXIMM Cs-137 PLATEOUT IN DRIVER ELEMENTS

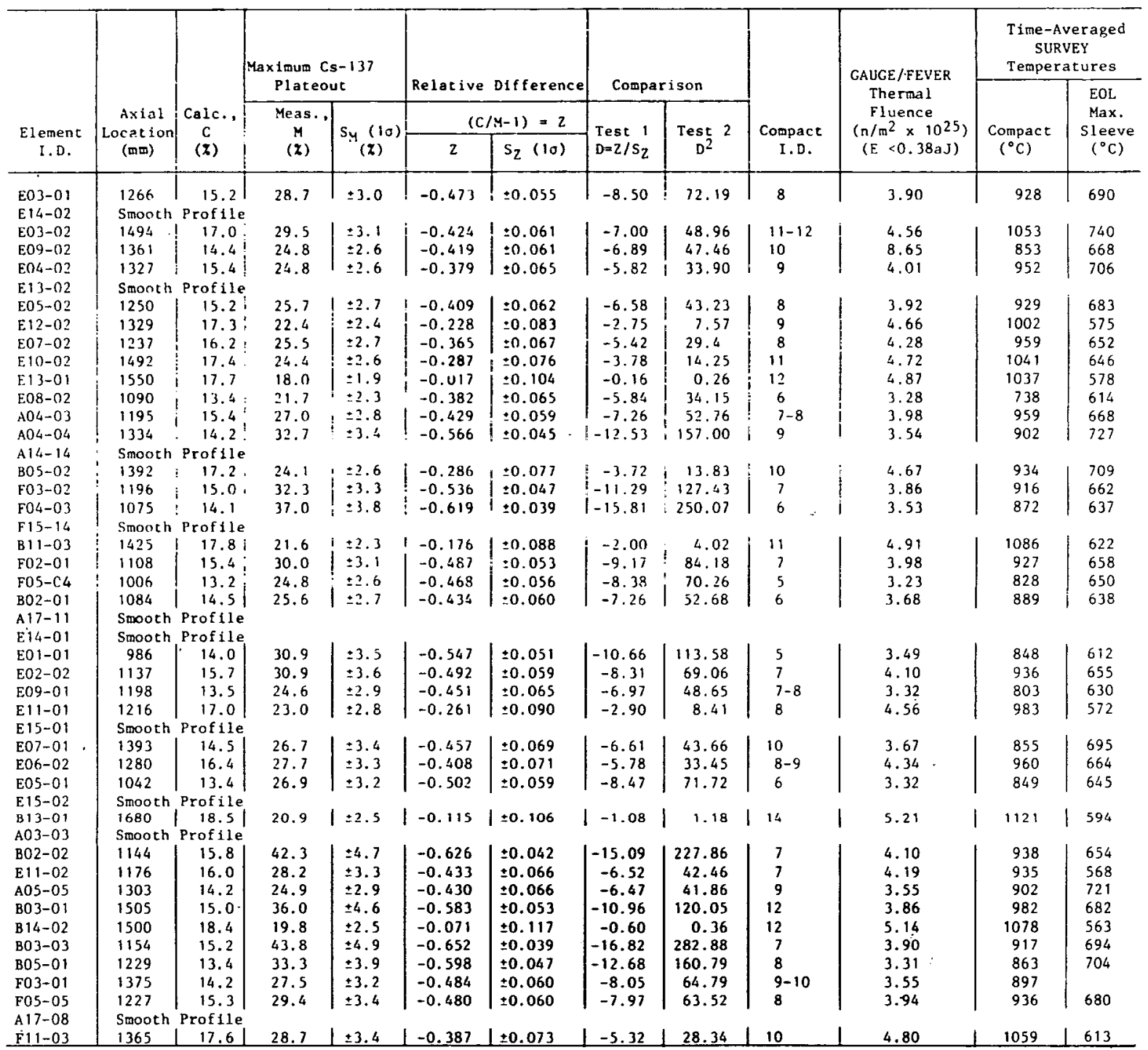


APPENDIX C

E14-01 DATA PACKAGE

C-1 


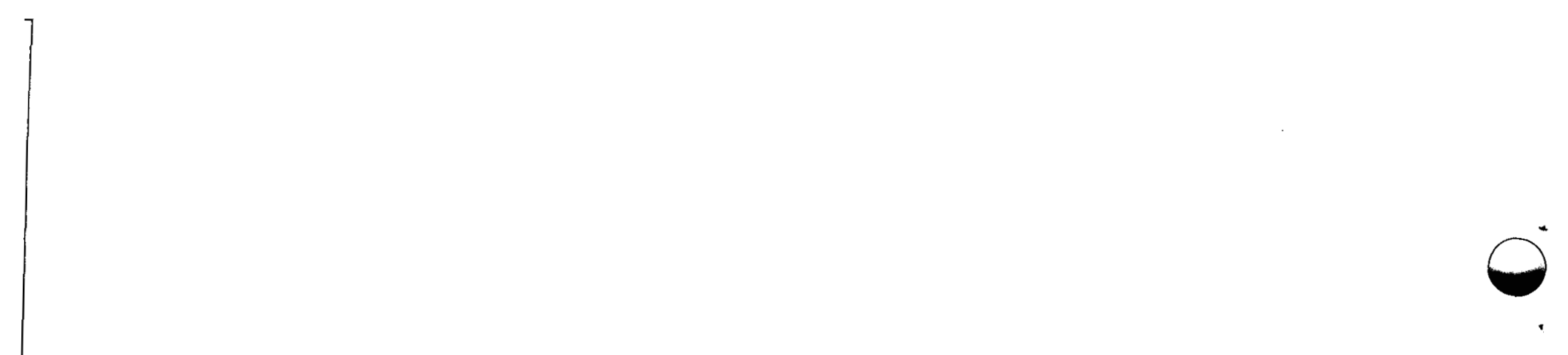


0

DISC has 15 PLOT Frames

0

ERRORS WERE DETECTED

* Exit loc*00407j

OXUT,O PBEOLES

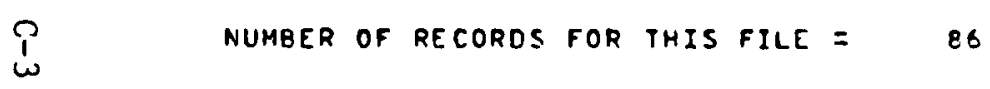

MISC. SCANS STPATAS

$\begin{array}{llll}106 & 107 & 10 \% & 115\end{array}$

$190 \quad 191 \quad 143 \quad 144$

$0 \quad: 45 \quad 152$

$\begin{array}{llll}0 & 2 & 0 & 0 \\ 0 & 0 & 0 & 0\end{array}$

$\begin{array}{llll}0 & 0 & 0 & ? \\ 0 & 0 & 0 & 0 \\ 0 & 0 & 0 & c\end{array}$

$\begin{array}{llll}0 & 0 & 0 & 0 \\ 0 & 0 & 0 & 0 \\ 0 & 0 & 0 & 0\end{array}$

$\begin{array}{llll}0 & c & 0 & c \\ 0 & j & c & 5\end{array}$

$\begin{array}{llll}0 & 0 & 0 & 0 \\ 0 & 0 & 0 & 0\end{array}$

FIRST RECORD

3 LAST RECORD \#

47

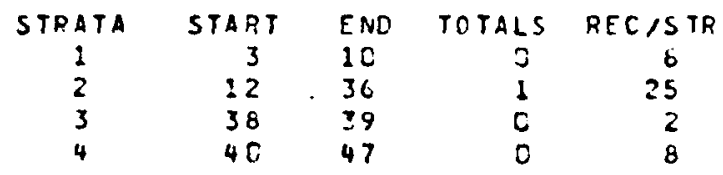




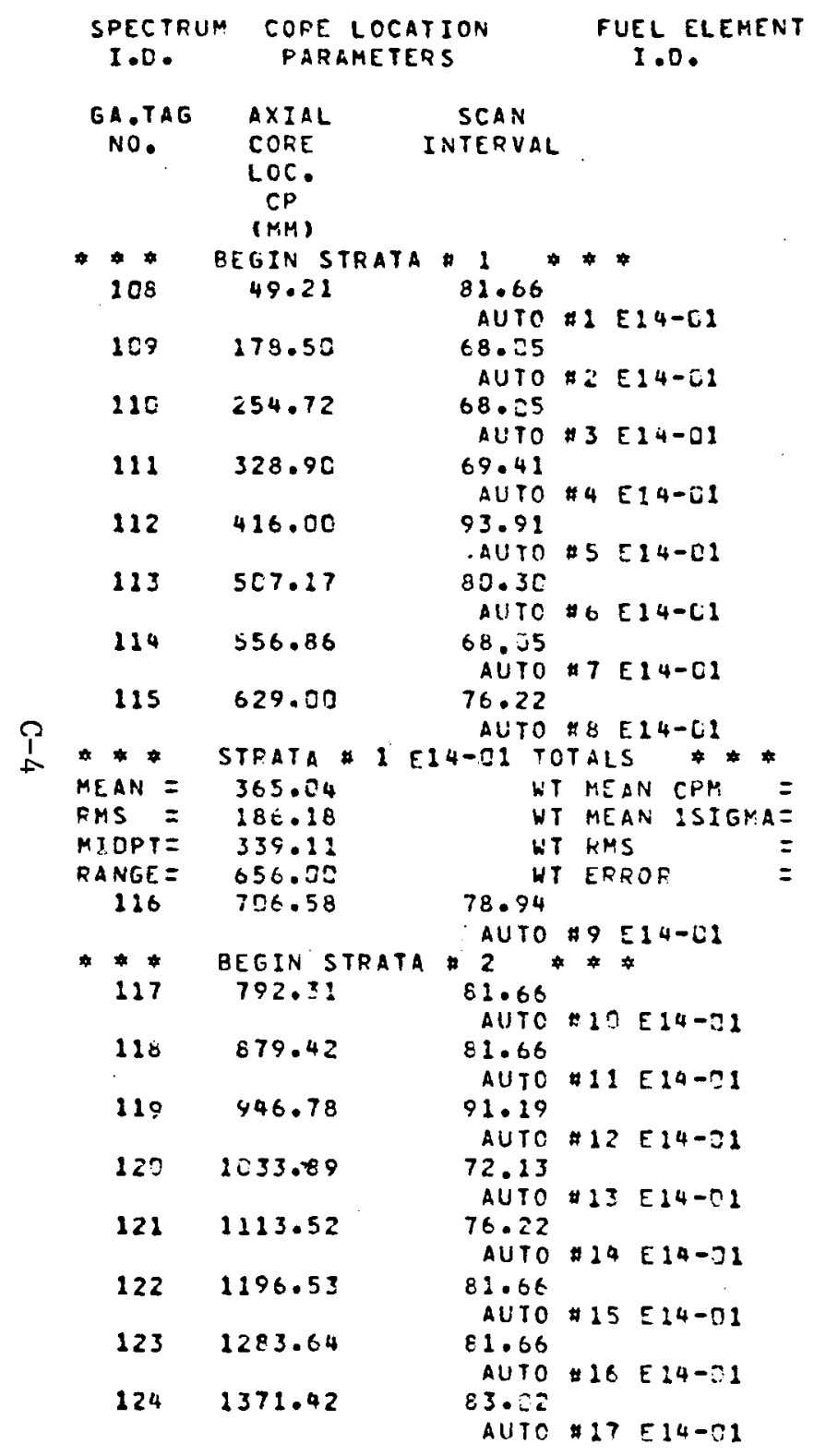
CE-144 CE-141 PA-233 I-131 RU-103 RU-1C6 CS-137 2R-95 CS-134 LA-140 I3 KEV 145 KEV 312 KEV 364 KEV 497 KEV 512 KEV 661 KEV 724 KEV 796 KEV 1596 KEV

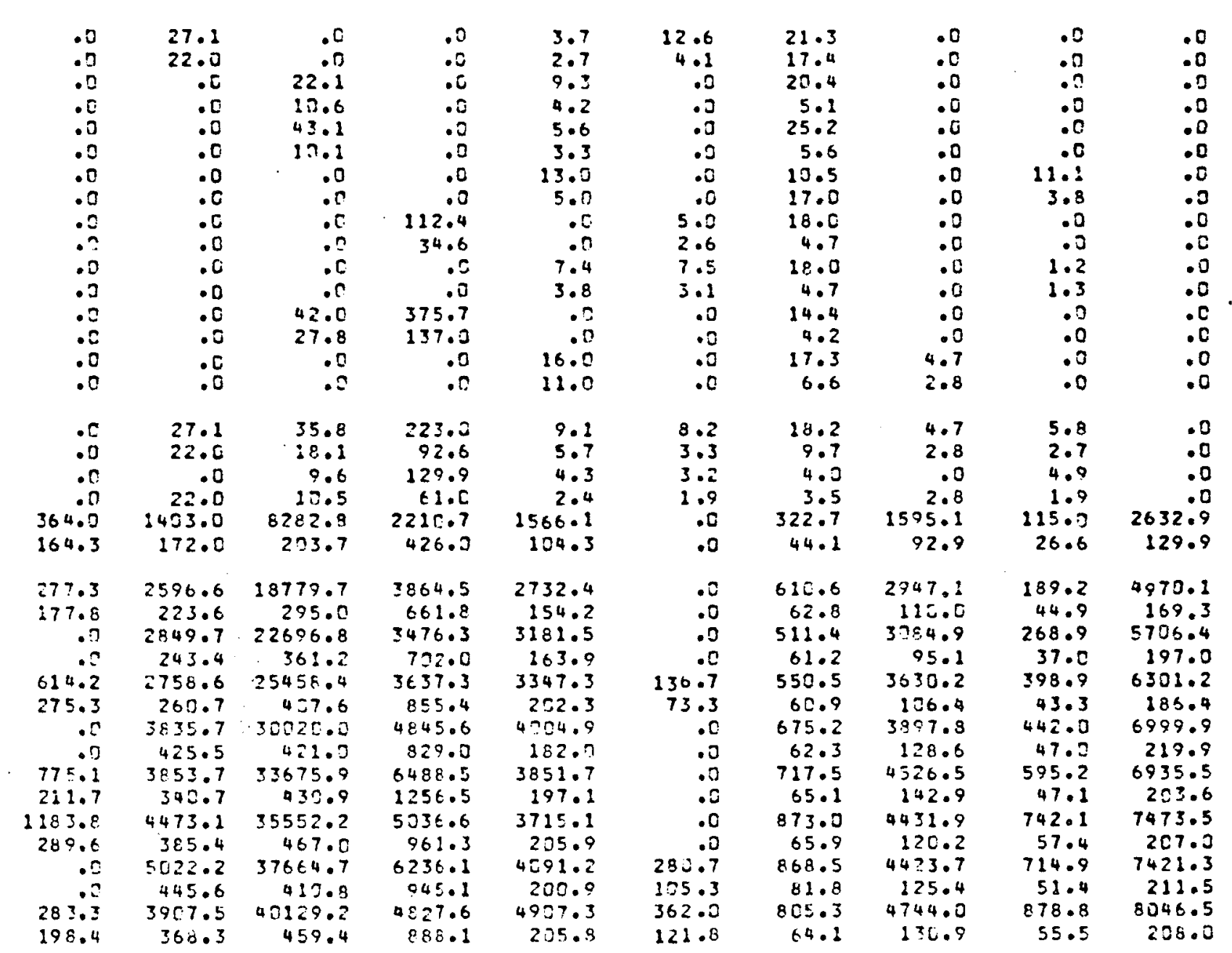




\begin{tabular}{|c|c|c|c|c|}
\hline $\begin{array}{l}\text { SPECTRU: } \\
\text { I.D. }\end{array}$ & $\begin{array}{l}\text { CORE } \\
\text { PARA }\end{array}$ & $\begin{array}{l}\text { ATION } \\
\text { ERS }\end{array}$ & & $\begin{array}{l}J E L \text { ELE } \\
I . D .\end{array}$ \\
\hline $\begin{array}{l}\text { GA.TAG } \\
\text { NO. }\end{array}$ & $\begin{array}{l}\text { AXIAL } \\
\text { CORE } \\
\text { LOC. } \\
\text { CP } \\
\text { (MM) }\end{array}$ & $\begin{array}{c}\text { SCAN } \\
\text { INTERVAL }\end{array}$ & & \\
\hline 125 & 1460.58 & $\begin{array}{c}84.38 \\
\text { AUTO }\end{array}$ & 218 & $=14-01$ \\
\hline 126 & 1547.68 & $\begin{array}{l}78.94 \\
\text { AUTO }\end{array}$ & $\$ 19$ & $E 14-01$ \\
\hline 127 & 1643.23 & $\begin{array}{r}95.27 \\
\text { AUTO }\end{array}$ & $\forall \geq 0$ & E $14-31$ \\
\hline 128 & 1730.06 & $\begin{array}{r}73.49 \\
A 470\end{array}$ & 421 & E $14-C 1$ \\
\hline 129 & 1811.71 & $\begin{array}{r}78.94 \\
\text { AUTO }\end{array}$ & 422 & $E 24-01$ \\
\hline 130 & 1896.77 & $\begin{array}{r}\text { BI. } 22 \\
\text { AUTO }\end{array}$ & $\$ 23$ & {$[14-\Gamma .1$} \\
\hline 131 & 1985.25 & $\begin{array}{r}83 . C 2 \\
\text { AUTO }\end{array}$ & .24 & E14-31 \\
\hline 132 & 2075.07 & $\begin{array}{r}\text { E5.74 } \\
\text { AUTO }\end{array}$ & $\$ 25$ & $E 14-C, 1$ \\
\hline 153 & 2160.90 & $\begin{array}{r}83.02 \\
\text { AUTO }\end{array}$ & 126 & E14-01 \\
\hline 134 & 2252.68 & $\begin{array}{l}81.66 \\
4 \cup 70\end{array}$ & $\$ 27$ & $\varepsilon\{4-02$ \\
\hline 135 & 2341.14 & $\begin{array}{r}84.38 \\
\text { AUTO }\end{array}$ & 128 & E14-01 \\
\hline 136 & 2430.98 & $\begin{array}{r}84 \cdot 38 \\
\text { AUTO }\end{array}$ & 429 & $E 14-01$ \\
\hline 137 & 2520.81 & $\begin{array}{r}84 \cdot 38 \\
\text { AUTO }\end{array}$ & 130 & E $14-01$ \\
\hline 238 & 2611.99 & $\begin{array}{l}67.11 \\
\text { AUTO }\end{array}$ & 431 & E $14-C 1$ \\
\hline 239 & 2701.81 & $\begin{array}{l}81.68 \\
\text { AUTO }\end{array}$ & 132 & $E: 4-01$ \\
\hline 145 & 2789.60 & $\begin{array}{r}83.02 \\
\text { AUTO }\end{array}$ & 433 & $E\left\{4-C_{1}\right.$ \\
\hline 141 & 2873.98 & $\begin{array}{r}77.58 \\
\text { AUTD }\end{array}$ & $\$ 34$ & $E: 4-51$ \\
\hline
\end{tabular}

\begin{tabular}{|c|c|c|c|c|c|c|c|c|c|}
\hline$C \varepsilon-144$ & $C E-141$ & $P A-233$ & $1-131$ & $R U-1 C 3$ & $R U-1=6$ & $C s-137$ & $7 R-95$ & $c 5-134$ & $(A-100$ \\
\hline $33 \mathrm{KEV}$ & $145 \mathrm{KEV}$ & 312 KEV & 364 KEV & $497 \mathrm{KEV}$ & 512 KEV & 662 KEV & 724 KEV & 796 KEV & $1596 \mathrm{KEV}$ \\
\hline 279.2 & 4933.5 & 42064.2 & 6642.2 & 4853.9 & $\because$ & 1001.8 & $51 \geq 1.8$ & 696 & 8062.3 \\
\hline 189.9 & & 446.5 & 1232.9 & 197.7 & .0 & 93.0 & $15 C \cdot 5$ & 55.4 & 213.1 \\
\hline 465.0 & 4769.9 & 1735.6 & $550 ? .3$ & 4356.1 & 136.1 & 886.4 & 5220.5 & 962.2 & 8081.8 \\
\hline 21 & 344.9 & 469.3 & 926.9 & 210.2 & 108.4 & 75.2 & 131.3 & 58.4 & 213.4 \\
\hline 879.1 & 5475.4 & 42542.4 & 7782.4 & 4489.7 & .0 & 1004.8 & 5235.7 & 967.5 & 8502.3 \\
\hline $\begin{array}{l}229.5 \\
754.8\end{array}$ & $\begin{array}{r}433.3 \\
4153.2\end{array}$ & $\begin{array}{r}048.6 \\
03757.6\end{array}$ & $\begin{array}{l}1512.3 \\
5159.9\end{array}$ & $\begin{array}{r}130.2 \\
4602.9\end{array}$ & $\begin{array}{r}.0 \\
213.6\end{array}$ & $\begin{array}{r}71.6 \\
882.0\end{array}$ & $\begin{array}{r}135.8 \\
98=1.2\end{array}$ & $\begin{array}{r}60.1 \\
937.4\end{array}$ & $\begin{array}{r}235.3 \\
8228.9\end{array}$ \\
\hline 259.4 & 472.1 & $4 \varepsilon 2.7$ & 870.9 & 207.3 & 134.5 & 79.7 & 133.7 & 54.6 & 209.8 \\
\hline 242.7 & 5152.7 & 41962.4 & 7729.5 & 49.17 .5 & 344.4 & 985.0 & 4921.1 & 1092.2 & 8506.3 \\
\hline 22 & $42 \mathrm{C} \cdot 2$ & $44: .4$ & 1077.3 & 212.7 & 110.6 & 70.6 & 128.7 & $79 \cdot 3$ & $21 t .2$ \\
\hline 828.4 & $5252 . .8$ & 42698.4 & 4532.6 & $407^{\circ} .2$ & .3 & 862.2 & 5157.6 & 1035.1 & 8214.6 \\
\hline 206.3 & $4 C 6.9$ & 452.2 & $8=4.4$ & 190.2 & .3 & 64.9 & 146.4 & 62.9 & 228.7 \\
\hline 308.5 & 4595.2 & 41399.0 & 6723.9 & 4777.5 & .3 & 971.1 & 4850.7 & 894.5 & 8236.5 \\
\hline $27 \Omega .4$ & $46 \pm .1$ & $486 . ?$ & 988.4 & 295.4 & . $c$ & 74.8 & 124.1 & 56.1 & 217.6 \\
\hline $111 \geq .8$ & 4829.0 & 41756.3 & 5450.3 & 3872.6 & 208.1 & 794.5 & $4 ; 47.3$ & 859.8 & 7769.3 \\
\hline $35 \div 8$ & $a \in 3.1$ & 5.74 .8 & 1887.4 & 211.2 & 126.7 & 68.0 & 133.6 & $52 . \Gamma$ & 204.4 \\
\hline 43.9 & 4876.7 & 41424.1 & 7.6 .1 .7 & 3769.3 & 342.8 & 833.2 & 4945.5 & 845.1 & 8265.8 \\
\hline $\begin{array}{l}189.4 \\
745.5\end{array}$ & $\begin{array}{r}415.3 \\
5033.8\end{array}$ & $\begin{array}{r}495.5 \\
40241.0\end{array}$ & $\begin{array}{l}1542.0 \\
5283.3\end{array}$ & $\begin{array}{r}20 ? .4 \\
4820.1\end{array}$ & $\begin{array}{l}105.5 \\
606.7\end{array}$ & $\begin{array}{r}67.7 \\
926.7\end{array}$ & $\begin{array}{r}199.1 \\
4955.8\end{array}$ & $\begin{array}{r}51.8 \\
894.3\end{array}$ & $\begin{array}{r}217.4 \\
8264.3\end{array}$ \\
\hline 253.6 & 530.1 & 496.2 & 1054.2 & 199.9 & $122 . c$ & 83.6 & $: 48 . J$ & 64.4 & 213.2 \\
\hline & 442 & $376 \geq 1.7$ & 0 & 4107.4 & 951.7 & 765.6 & 4478.6 & 643.4 & 7579.1 \\
\hline & 436.9 & 4.2 .3 & 1176.8 & 217.5 & 133.7 & 69.2 & 125.1 & 51.2 & 207.4 \\
\hline 569.9 & 4243.1 & 35263.6 & $424 \geq .0$ & 4419.2 & 797.0 & 765.5 & 4525.3 & 801.8 & 7335.1 \\
\hline & & & 892.5 & 192.5 & 147.4 & 73.6 & $14 \varepsilon \cdot 2$ & 65.3 & 215.3 \\
\hline . 0 & $425: .00$ & 33438.4 & 3991.0 & 4092.5 & 679.1 & 836.7 & 4202.2 & 567.3 & 6727.5 \\
\hline .0 & & $4 \in 9.2$ & 1.7 & 208.6 & 133.1 & $7 \geq .9$ & 133.2 & 45.7 & 194.7 \\
\hline 712.7 & 3996.7 & $3[675.3$ & 3.339 .8 & 3976.8 & 887.8 & 604.6 & $39-4.3$ & 499.3 & 6561.5 \\
\hline 217.1 & 512.5 & 474.7 & 364.1 & $212 \cdot 2$ & 140.0 & 75.0 & 129.3 & 51.7 & 189.5 \\
\hline 464.1 & 3908.2 & 28433.0 & 4546.7 & 3949.4 & 943.6 & 746.7 & 3934.9 & 442.0 & 6613.7 \\
\hline 8.1 & $50 \geq .3$ & 437.9 & 873.1 & 198.3 & 140.8 & 84.4 & 132.9 & 47.6 & 191.5 \\
\hline .0 & 3524.1 & 26103.6 & 2845.0 & $36 \geq 7.0$ & 862.3 & 562.5 & 3588.7 & 376.9 & 5826.2 \\
\hline$\therefore$ & 254.0 & 487.5 & 256.5 & 190.5 & 107.2 & 69.5 & 123.8 & 39.3 & 180.1 \\
\hline 31.5 & $349 t .5$ & 2.2472 .7 & $3=84.1$ & 3787.1 & 1153.6 & 454.0 & 3215.9 & 358.5 & 5520.4 \\
\hline 709.9 & $43 E .3$ & $4=3.5$ & 947.8 & 200.6 & 150.2 & 55.8 & 111.8 & 43.1 & 191.8 \\
\hline
\end{tabular}




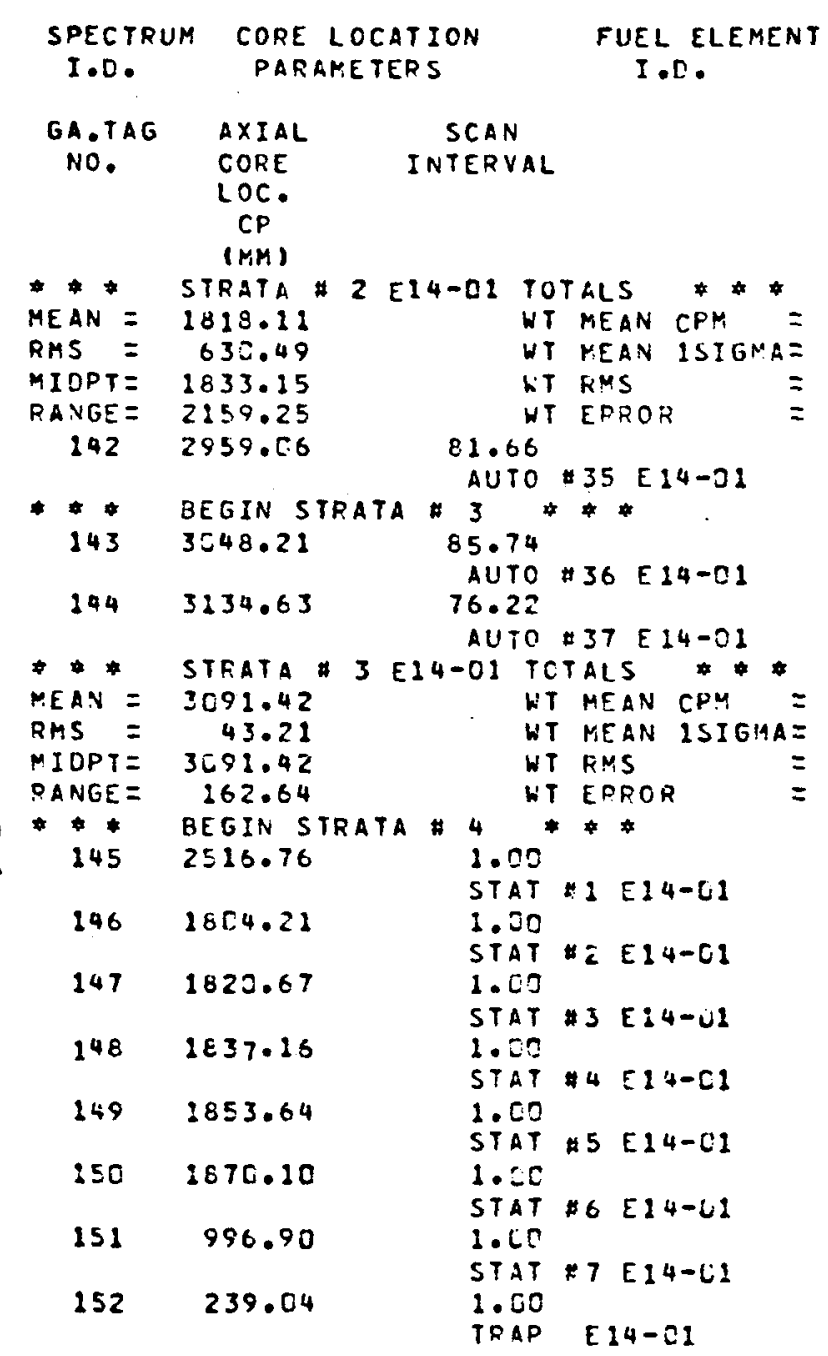

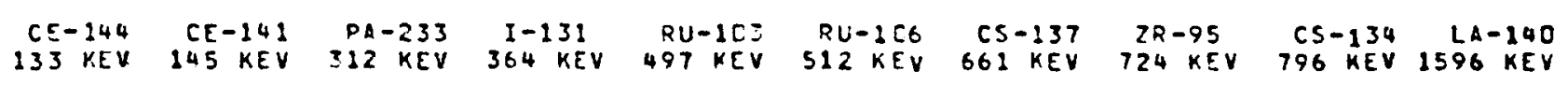

NUCLIDE CPM - 1 - 1 SIGMA COUNTING ERROQ

\begin{tabular}{|c|c|c|c|c|c|c|c|c|c|}
\hline $\begin{array}{r}666.3 \\
241.8 \\
283.8 \\
55.6 \\
656.1 \\
265.3\end{array}$ & $\begin{array}{r}4241.4 \\
414.7 \\
769.5 \\
93.1 \\
2256.1 \\
484.3\end{array}$ & $\begin{array}{r}35293.0 \\
448.8 \\
7445.2 \\
95.0 \\
19693.6 \\
341.6\end{array}$ & $\begin{array}{r}5158.9 \\
1029.7 \\
1453.2 \\
207.3 \\
4653.9 \\
278.3\end{array}$ & $\begin{array}{r}4056.8 \\
199.2 \\
573.8 \\
39.9 \\
3614.6 \\
150.3\end{array}$ & $\begin{array}{r}565.7 \\
123.7 \\
335.2 \\
30.9 \\
1014.7 \\
123.6\end{array}$ & $\begin{array}{r}783.2 \\
71.5 \\
153.9 \\
14.3 \\
652.6 \\
58.1\end{array}$ & $\begin{array}{r}4377.9 \\
130.7 \\
655.5 \\
26.2 \\
3420.5 \\
175.3\end{array}$ & $\begin{array}{r}693.2 \\
53.6 \\
254.8 \\
10.7 \\
221.2 \\
48.3\end{array}$ & $\begin{array}{r}7292.0 \\
208.3 \\
2007.4 \\
41.3 \\
5607.7 \\
180.7\end{array}$ \\
\hline $\begin{array}{l}.0 \\
.0 \\
.0 \\
.0\end{array}$ & $\begin{array}{l}.0 \\
.0 \\
.0 \\
.0\end{array}$ & $\begin{array}{l}.0 \\
.0 \\
.0 \\
.0\end{array}$ & $\begin{array}{l}.0 \\
.0 \\
.0 \\
.0\end{array}$ & $\begin{array}{l}.0 \\
.0 \\
.0 \\
.0\end{array}$ & $\begin{array}{r}951.2 \\
71.6 \\
875.2 \\
63.1\end{array}$ & $\begin{array}{l}.0 \\
.0 \\
.0 \\
.0\end{array}$ & $\begin{array}{l}.0 \\
.0 \\
.2 \\
.0\end{array}$ & $\begin{array}{l}.0 \\
.0 \\
.0 \\
.0\end{array}$ & $\begin{array}{l}.0 \\
.0 \\
.0 \\
.0\end{array}$ \\
\hline $\begin{array}{l}.0 \\
.0 \\
.0 \\
.0\end{array}$ & $\begin{array}{l}.0 \\
.0 \\
.0 \\
.0\end{array}$ & $\begin{array}{l}.0 \\
.0 \\
.0 \\
.0\end{array}$ & $\begin{array}{l}.2 \\
.0 \\
.0 \\
.0\end{array}$ & $\begin{array}{l}.0 \\
.2 \\
.0 \\
.0\end{array}$ & $\begin{array}{r}915.4 \\
66.3 \\
38.3 \\
47.3\end{array}$ & $\begin{array}{l}.0 \\
.0 \\
.0 \\
.0\end{array}$ & $\begin{array}{r}.0 \\
.0 \\
.0 \\
.0\end{array}$ & $\begin{array}{l}.0 \\
.0 \\
.0 \\
.0\end{array}$ & $\begin{array}{l}.0 \\
.0 \\
.0 \\
.0\end{array}$ \\
\hline $\begin{array}{r}481.3 \\
85.1 \\
54 \mathrm{C} .1 \\
83.6 \\
664.6\end{array}$ & $\begin{array}{r}4521.5 \\
220.3 \\
4829.5 \\
203.7 \\
4796.6\end{array}$ & $\begin{array}{r}32374.7 \\
195.3 \\
41073.2 \\
196.2 \\
41587.5\end{array}$ & $\begin{array}{r}4994.7 \\
455.9 \\
5116.3 \\
393.7 \\
6114.3\end{array}$ & $\begin{array}{r}4285.1 \\
82.4 \\
4472.9 \\
83.4 \\
4642.7\end{array}$ & $\begin{array}{r}859.0 \\
50.6 \\
255.8 \\
40.9 \\
127.7\end{array}$ & $\begin{array}{r}677.4 \\
29.3 \\
925.0 \\
31.2 \\
923.3\end{array}$ & $\begin{array}{r}4190.0 \\
53.3 \\
4696.1 \\
53.2 \\
4753.8\end{array}$ & $\begin{array}{r}540.4 \\
21.6 \\
961.1 \\
26.9 \\
998.3\end{array}$ & $\begin{array}{r}7050.2 \\
80.6 \\
7599.1 \\
82.9 \\
8134.0\end{array}$ \\
\hline $\begin{array}{l}200.0 \\
129.9 \\
515.2\end{array}$ & $\begin{array}{r}149.9 \\
4524.9\end{array}$ & $\begin{array}{r}195.5 \\
41714.3\end{array}$ & $\begin{array}{r}437.5 \\
6136.1\end{array}$ & $\begin{array}{r}83.8 \\
4596.8\end{array}$ & $\begin{array}{r}32.7 \\
119.3\end{array}$ & $\begin{array}{r}30.8 \\
991.7\end{array}$ & $\begin{array}{r}54.2 \\
4674.6\end{array}$ & $\begin{array}{r}24.7 \\
940.1\end{array}$ & $\begin{array}{r}86.5 \\
7971.2\end{array}$ \\
\hline $\begin{array}{r}58.9 \\
741.0 \\
80.5\end{array}$ & $\begin{array}{r}158.9 \\
178.2\end{array}$ & $\begin{array}{r}290.4 \\
1256.0 \\
156.5\end{array}$ & $\begin{array}{r}5202.1 \\
397.5\end{array}$ & $\begin{array}{r}89.4 \\
4713.5 \\
79.9\end{array}$ & $\begin{array}{r}33.5 \\
234.5 \\
42.3\end{array}$ & $\begin{array}{r}970.4 \\
36.0\end{array}$ & $\begin{array}{r}54.8 \\
4874.9 \\
55.0\end{array}$ & $\begin{array}{r}24.5 \\
903.9 \\
25.9\end{array}$ & $\begin{array}{r}85.2 \\
7725.8 \\
85.7\end{array}$ \\
\hline $\begin{array}{r}683.6 \\
86.4 \\
503.2\end{array}$ & $\begin{array}{r}5286.1 \\
181.1 \\
3921.6\end{array}$ & $\begin{array}{r}47155.7 \\
215.2 \\
32543.2\end{array}$ & $\begin{array}{r}6278.8 \\
393.8 \\
5375.3\end{array}$ & $\begin{array}{r}5262.5 \\
88.3 \\
4337.2\end{array}$ & $\begin{array}{r}214.2 \\
43.4 \\
195.4\end{array}$ & $\begin{array}{r}1132.2 \\
36.0 \\
765.0\end{array}$ & $\begin{array}{r}5533.9 \\
61.6 \\
4261.4\end{array}$ & $\begin{array}{r}999.8 \\
24.7 \\
521.7\end{array}$ & $\begin{array}{r}8703.1 \\
89.3 \\
7227.1\end{array}$ \\
\hline $\begin{array}{r}65.4 \\
.0 \\
.0\end{array}$ & $\begin{array}{r}125.2 \\
.0 \\
.0\end{array}$ & $\begin{array}{r}170.7 \\
.7 \\
.5\end{array}$ & $\begin{array}{r}408.6 \\
.0 \\
.0\end{array}$ & $\begin{array}{r}77.2 \\
.0 \\
.0\end{array}$ & $\begin{array}{r}43.1 \\
.0 \\
.0\end{array}$ & $\begin{array}{r}30.2 \\
20.1 \\
3.6\end{array}$ & $\begin{array}{r}49.9 \\
.0 \\
.0\end{array}$ & $\begin{array}{r}22.4 \\
.0 \\
.0\end{array}$ & $\begin{array}{r}80.4 \\
.0 \\
.0\end{array}$ \\
\hline
\end{tabular}




$\begin{array}{llc}\text { SPECTRUM CORE LOCATION } & \text { FUEL ELEMENT } \\ \text { I.D. } & \text { PARAMETERS } & \text { I.O. } \\ \text { GA.TAG AXIAL S SCAN }\end{array}$

GATTAG AXIAL SCAN

NO. CORE INTERVAL

LOC. (MM)

* strata * 4 el4-0l totals

MEAN = 1617.31 HT MEAN CPII

$\begin{array}{ll}\text { MEAN }=1617.31 & \text { WT MEAN CPH = } \\ \text { RMS }=645.94 & \text { WT MEAN ISIGMAE }\end{array}$

MIOPT $=1377.90$

RANGE $=-2276.72$

WT MEAN
WT RMS

WT ERROR

$C E-144$
133 KEV

$C E-241$

$P Q-233$
312 KEV

NUCLINE CPM + - - I SIGMA COUNTING ERROR

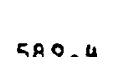

$\begin{aligned} \text { MEAN } & =1818.11 \\ \text { PMS } & =632.49\end{aligned}$

PMS $=632.49$
MIDPT $=1833.15$

RANGE $=2159.25$
WT MEAN CPM =
WT MEAN ISIGMA= WT RMS
HT ERROR

WT MEAN CPM $=666.0$
WT MEAN ISIGMA $=241.8$ $28 \geq .8$ 55.6

$\begin{array}{rrrrr}4241.4 & 35093.0 & 5158.9 & 4056.8 & 565.7 \\ 414.7 & 448.8 & 1329.7 & 199.2 & 123.7 \\ 769.5 & 7445.2 & 1450.2 & 573.8 & 335.2 \\ 83.1 & 90.0 & 207.3 & 39.9 & 30.9\end{array}$

CS-134 LA-140 796 KEV 1596 KEV 
M ISCELLANEOUS SCANS

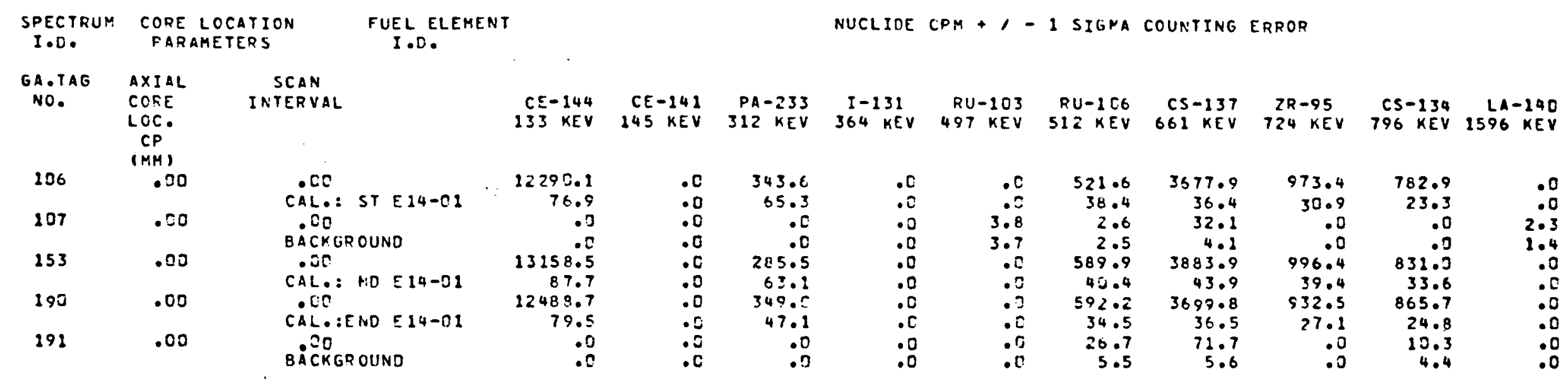




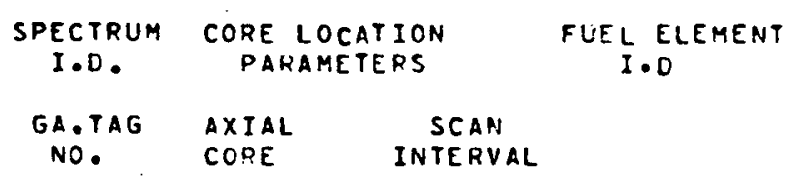

NUCLIOE CPM RATIOS AND I SIGMA ERRORS

$\begin{array}{lllllll}C E-141 & C E-144 & I-131 & R U-103 & C S-137 & R U-106 & C S-134 \\ Z R-95 & Z R-95 & Z R-95 & Z R-95 & Z R-95 & 2 R-95 & C S-137\end{array}$

\begin{tabular}{|c|c|c|c|c|c|c|}
\hline $\begin{array}{l}-c c 0 \\
.000 \\
.200 \\
.020 \\
.000 \\
.300 \\
.000 \\
.0100 \\
.000 \\
.000\end{array}$ & 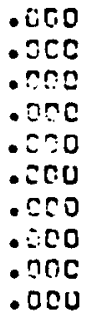 & 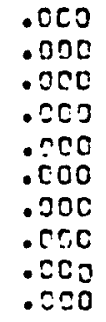 & $\begin{array}{l}.000 \\
.0 .70 \\
.050 \\
.<50 \\
.050 \\
.000 \\
.250 \\
.0 \div 0 \\
.000 \\
.000\end{array}$ & $\begin{array}{l}.000 \\
.000 \\
.000 \\
.000 \\
.000 \\
.000 \\
.000 \\
.000 \\
.000 \\
.000\end{array}$ & $\begin{array}{l}.000 \\
.000 \\
.000 \\
.000 \\
.000 \\
-000 \\
.000 \\
.000 \\
.000 \\
.000\end{array}$ & $\begin{array}{r}.000 \\
.000 \\
.000 \\
.000 \\
.000 \\
.000 \\
1.051 \\
1.739 \\
.000 \\
.000\end{array}$ \\
\hline $\begin{array}{l}.000 \\
.000\end{array}$ & $\begin{array}{l}\because \approx 0 \\
\therefore \leq 0\end{array}$ & $\begin{array}{l}\text {-ccc } \\
\text { - cecus }\end{array}$ & $\begin{array}{l}.020 \\
.200\end{array}$ & $\begin{array}{l}.000 \\
.000\end{array}$ & $\begin{array}{l}-\approx \Omega c \\
-c=0\end{array}$ & $\begin{array}{r}.068 \\
.072\end{array}$ \\
\hline $\begin{array}{l}.5=0 \\
. r 50 \\
.000 \\
.000\end{array}$ & 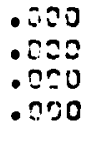 & $\begin{array}{l}.300 \\
.000 \\
.050 \\
.000\end{array}$ & $\begin{array}{r}.020 \\
.6=0 \\
3.458 \\
3.080\end{array}$ & $\begin{array}{r}.000 \\
.000 \\
3.675 \\
2.581\end{array}$ & $\begin{array}{l}.000 \\
.000 \\
.000 \\
.000\end{array}$ & $\begin{array}{l}.000 \\
.000 \\
.000 \\
.000\end{array}$ \\
\hline $\begin{array}{l}-\mathrm{JCu} \\
\text { - oco }\end{array}$ & $\begin{array}{l}.550 \\
.050\end{array}$ & $\begin{array}{l}.5 C a \\
. \cos \end{array}$ & $\begin{array}{l}3.4 C 8 \\
3.080\end{array}$ & $\begin{array}{l}3.675 \\
2.581\end{array}$ & $\begin{array}{l}\text { - coo } \\
\text { - }\end{array}$ & $\begin{array}{r}.524 \\
1.185\end{array}$ \\
\hline ס0כ0 & $\begin{array}{l}\text { - 0ro } \\
\text { - orc }\end{array}$ & $\begin{array}{l}\text { Ecc } \\
\therefore \Delta 00\end{array}$ & $\begin{array}{r}.000 \\
3.080\end{array}$ & $\begin{array}{r}.000 \\
2.581\end{array}$ & $\begin{array}{l}.000 \\
.000\end{array}$ & $\begin{array}{l}.495 \\
.807\end{array}$ \\
\hline .881 & .594 & 1.311 & .927 & .207 & - VOC & .310 \\
\hline .063 & .360 & .230 & .063 & .023 & .000 & .CBD \\
\hline .924 & $.00 C$ & 1.127 & 1.031 & $.16 \mathrm{t}$ & - $[\cap \cap C$ & .526 \\
\hline $\begin{array}{r}.084 \\
.760\end{array}$ & $\begin{array}{l}-3<0 \\
.169\end{array}$ & $\begin{array}{r}.2 \geq 0 \\
1.0<2\end{array}$ & $\begin{array}{l}. C \leq 2 \\
.922\end{array}$ & $\begin{array}{r}.020 \\
.252\end{array}$ & $\begin{array}{l}.000 \\
.038\end{array}$ & $\begin{array}{l}.096 \\
.725\end{array}$ \\
\hline $\begin{array}{r}.075 \\
.984 \\
.114\end{array}$ & $\begin{array}{l}.576 \\
.020 \\
.800\end{array}$ & $\begin{array}{r}.237 \\
1.243 \\
.217\end{array}$ & $\begin{array}{r}.062 \\
1.027 \\
.058\end{array}$ & $\begin{array}{l}.017 \\
.173 \\
.017\end{array}$ & $\begin{array}{l}\text {. C20 } \\
.000 \\
. c 00\end{array}$ & $\begin{array}{l}.112 \\
.655 \\
.092\end{array}$ \\
\hline .851 & .171 & 1.433 & .851 & .159 & .000 & .829 \\
\hline $\begin{array}{r}.08 c \\
.039\end{array}$ & $\begin{array}{l}.247 \\
.267\end{array}$ & $\begin{array}{r}.281 \\
1.136\end{array}$ & $\begin{array}{l}.051 \\
.838\end{array}$ & $\begin{array}{r}.215 \\
.297\end{array}$ & $\begin{array}{l}-C C O \\
-C O D\end{array}$ & $\begin{array}{l}.100 \\
.850\end{array}$ \\
\hline $\begin{array}{r}.291 \\
1.135\end{array}$ & $\begin{array}{l}-\because 66 \\
-\because 00\end{array}$ & $\begin{array}{r}.219 \\
1.410\end{array}$ & $\begin{array}{r}0527 \\
.925\end{array}$ & $\begin{array}{l}.016 \\
.196\end{array}$ & $\begin{array}{l}-0 \leq 0 \\
.063\end{array}$ & $\begin{array}{r}.092 \\
.823\end{array}$ \\
\hline .106 & .000 & .217 & .052 & .019 & .024 & .098 \\
\hline .824 & .260 & 1.018 & 1.034 & .170 & .076 & 1.091 \\
\hline . 021 & 0.42 & .189 & $.0 \leq 2$ & .014 & .026 & .111 \\
\hline .961 & $\cdot[54$ & 1.294 & .936 & .195 & .000 & .895 \\
\hline .098 & .037 & .244 & .048 & .019 & $\cdot \cos$ & .100 \\
\hline
\end{tabular}




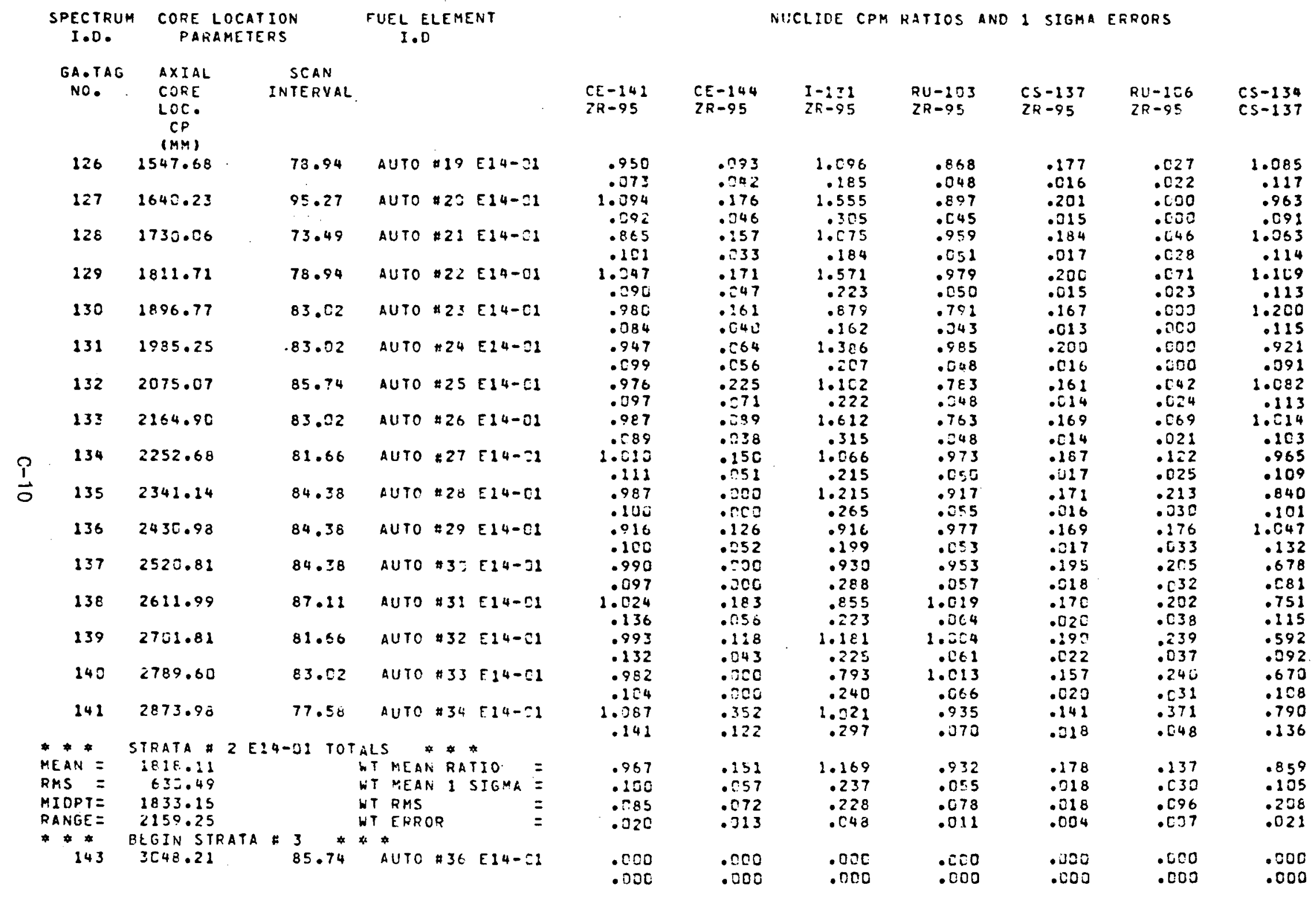




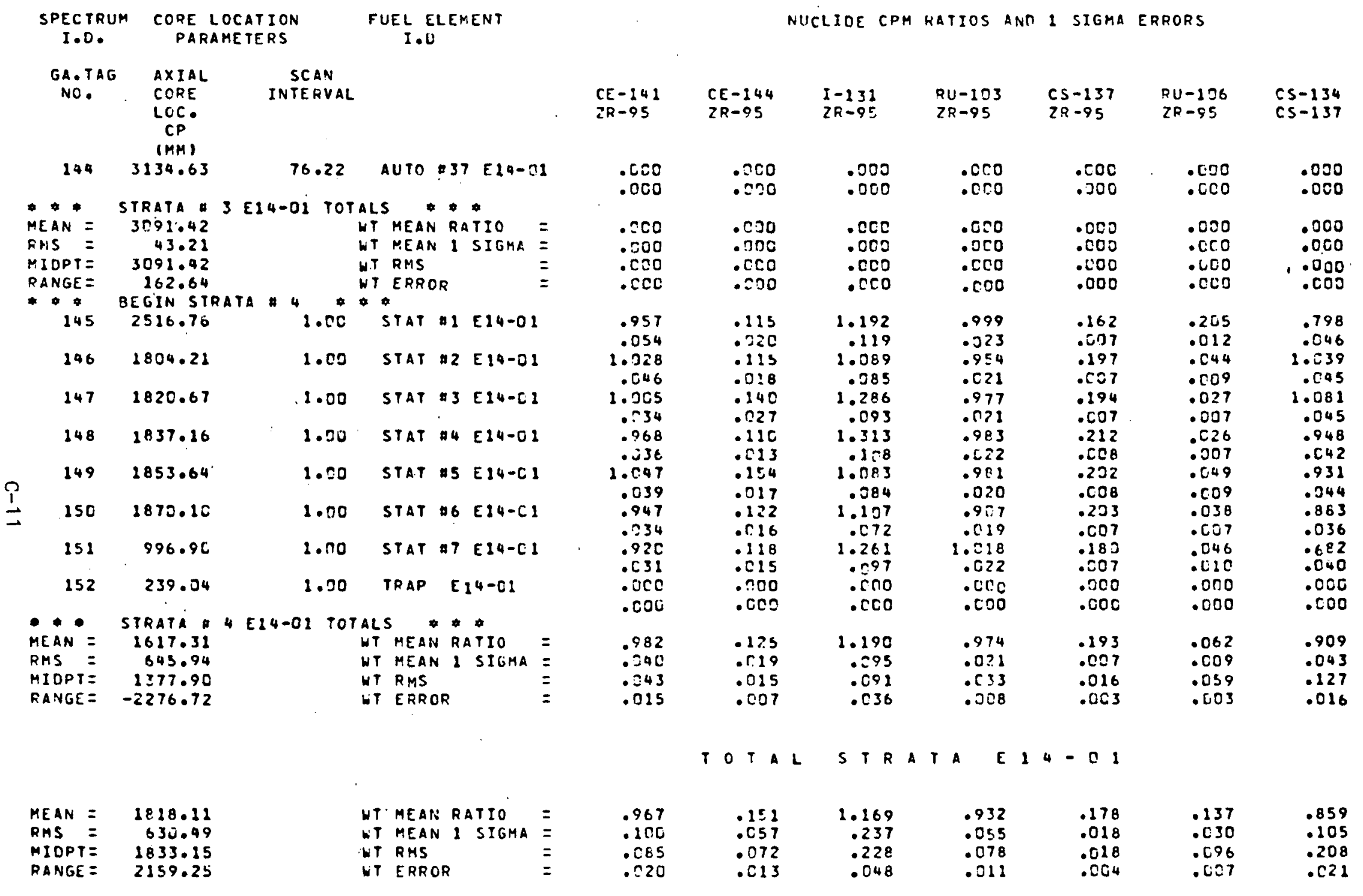




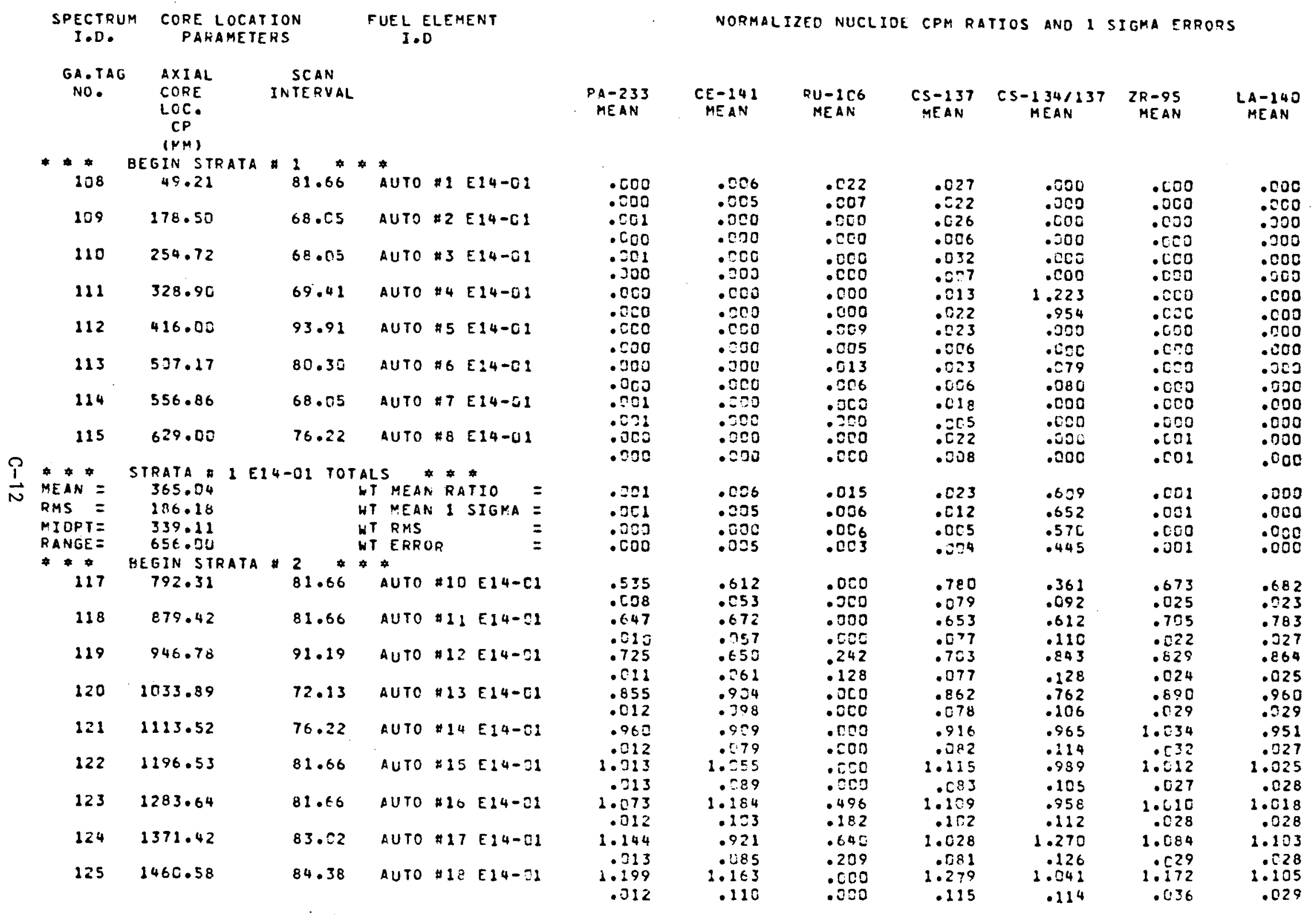




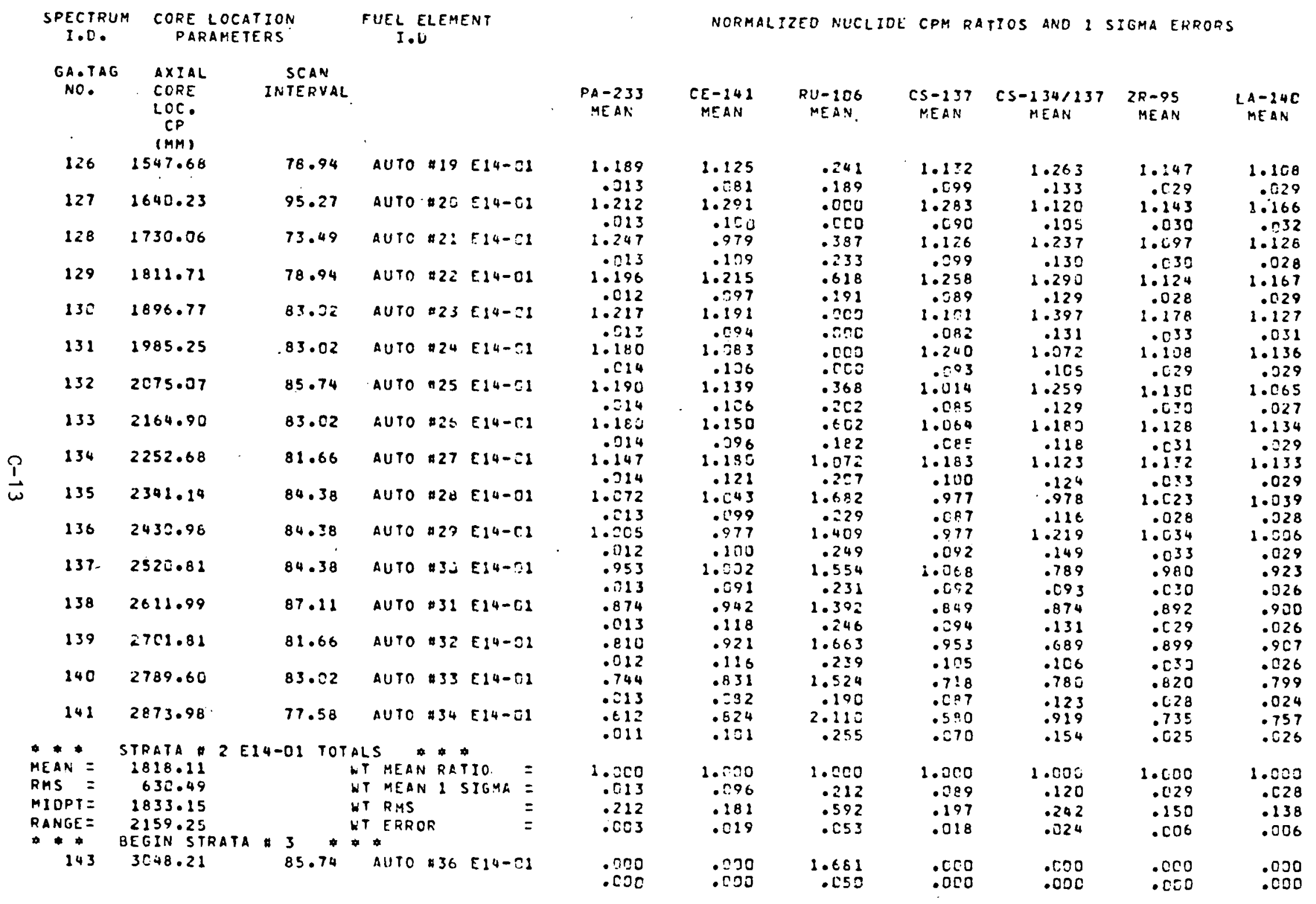




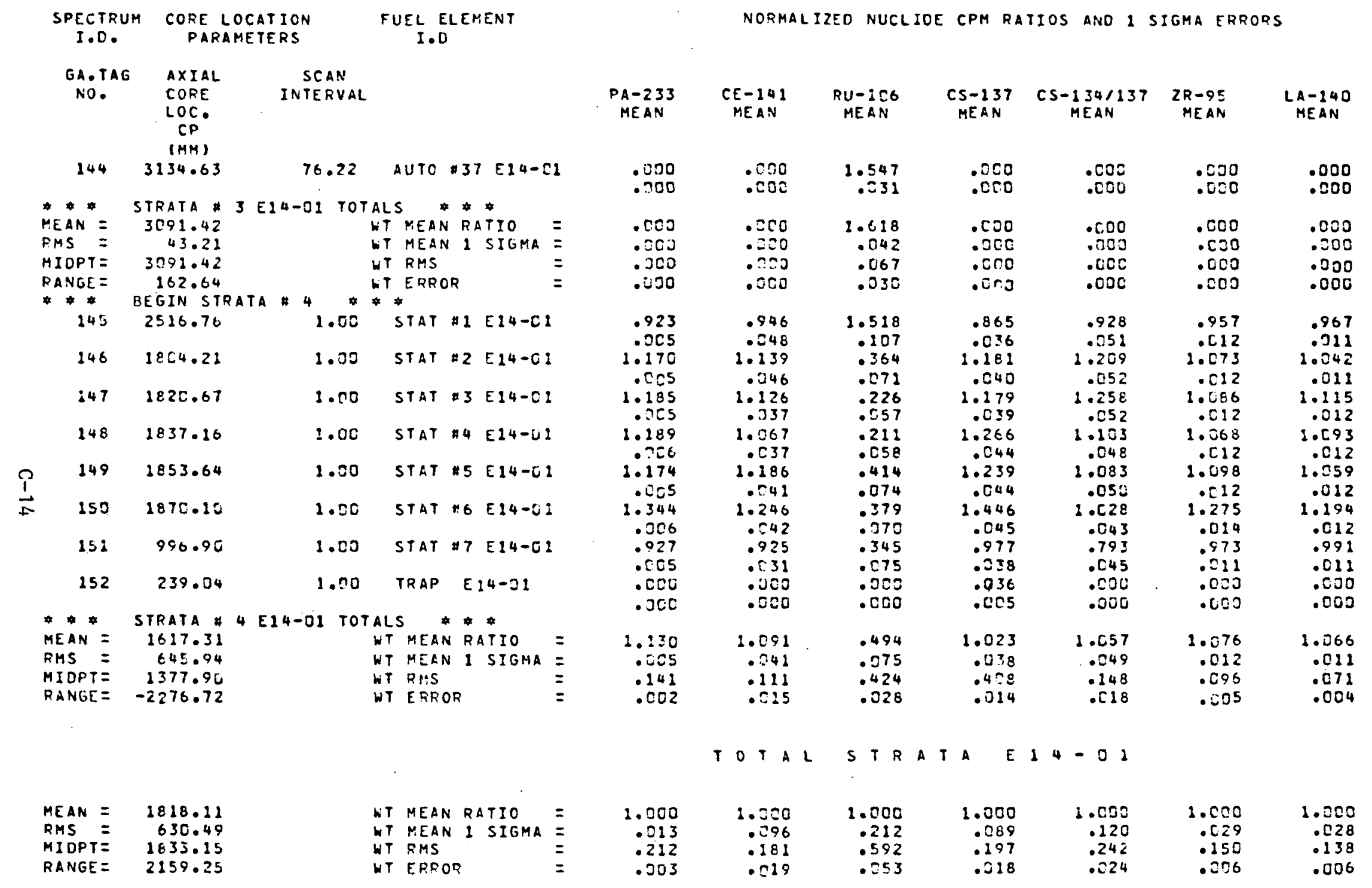


ABSOLUTE NUCLIDE ACTIVITIES ANO COMPOSITE BURNUP

FUEL IOENTIFICATION

TAG CORE INTERVAL

* aegin sirata l

AUTO H1 $514-01$

$109 \quad 178.50 \quad 68.55$

AUTO *2 E14-CI

$110 \quad 254.72 \quad 68.05$

AUTO 3 E $14-C$ ?

$121 \quad 328.90 \quad 69.42$ LUTO :4 E14-0

$112 \quad 416.0 \mathrm{C} \quad 93.91$

AUTO म5 E:4-C:

$\begin{array}{lll}13 \quad 507.17 & 80.30\end{array}$

SUTO 50 E $14-01$

AUTO $=7$ E14-CI

$125 \quad 629.2 C \quad 76.22$

* aUTO DSEI4-C? STRATA I EI4-0I TOTALS

CE -144
133 Y EV

CE-141

NUCLIDE CII) +1- I SIGMA ERROR

A-233 I-131 RU-103 RU-106 CS-1 SCLKEV $497 K E$

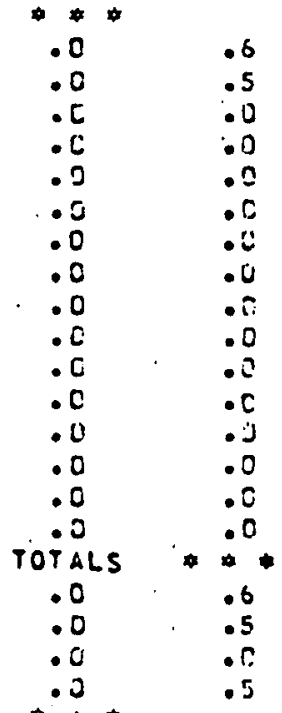

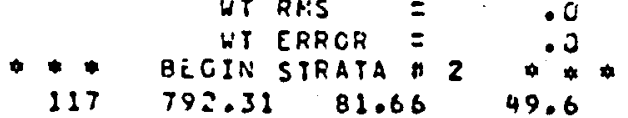

WT HEAN
HT I SIGHA
WT RHSS

$117792.31 \quad 81.66 \quad 49.6$
AUTO 910 E14-0i

$118 \quad 879.42 \quad 81.66$

AUTO И21 $[14-C 1$

200.0

2UTO म12 $140-01$

I2C $2033.8 .9 \quad 72.13$

AUTO 13 E14-C1

$221113.52 \quad 76.22$

AUTO $14 \quad 5: 14-01$

$2221196.53 \quad 81.66$ AUTO \#15 E\$4-01

$223 \quad: 283.64 \quad 81.66$

$124: 371.42 \quad 83.02$ AUTO 17 E $14-01$

$125 \quad 1450.59 \quad 84.38$

AUTO \& 18 E14-DI

\section{.0}

209.8

C. 5

.0

138.5

40.4

212.5

56.1

50.0
30.0

35.8

34.2

$\begin{array}{lll}.0 & .0 & .1 \\ .0 & .0 & .0 \\ .5 & .0 & .1 \\ .3 & .0 & .1 \\ 1.0 & .0 & .1 \\ .3 & .0 & .0 \\ .0 & .0 & .2 \\ .0 & .0 & .1 \\ .0 & 1.4 & .1 \\ .0 & .4 & .0 \\ .0 & .0 & .1 \\ .0 & .0 & .1 \\ 1.0 & 4.5 & .0 \\ .7 & 1.7 & .3 \\ .0 & .0 & .2 \\ .0 & .0 & .2\end{array}$

$2 \cdot 7$

1.2
1.6

$54.3 \quad 437.3$

$\begin{array}{rr}7.3 & 45.4 \\ 59.6 & 528.5\end{array}$

8.354 .9

$57.7 \quad 592.8$

$8.0 \quad 61.5$

en.2 639.7

12. 1

20.6

10.8

93.5

14.2

81.7

11.4

24.6

72.4
754.1

$81 . C$

627.8

55.6
877.2

90.5

$9 \geq 4.4$

96.4
979.4

46.5

9.3
41.9

9.5

43.8

11.2

53.4
11.6

21.6
78.1

$17 \cdot 1$

63.7

13.1

75.1

13.7
$58 . ?$

12.2
$3 \div .0$

27.0

$7 \cdot 5$
101.0
$C 5-137$
$662 K E V$

ZR- 95
$724 \times E V$

$C S-134$
$796 K E V$

$\angle A-290$ IS96KEV COMPOSITE FIMA

CS-137 RU-106 MONITOR MONITO

$$
\begin{aligned}
& .8 \\
& .3 \\
& .0 \\
& .0 \\
& .0 \\
& .0 \\
& .0 \\
& .0 \\
& .3 \\
& .2 \\
& .5 \\
& .2 \\
& .0 \\
& .2 \\
& .0 \\
& .0
\end{aligned}
$$$$
\begin{aligned}
& .4 \\
& .3 \\
& .4 \\
& .1 \\
& .5 \\
& .1 \\
& .2 \\
& .3 \\
& .3 \\
& .2 \\
& .3 \\
& .1 \\
& .3 \\
& .1 \\
& .3 \\
& .1
\end{aligned}
$$$$
\begin{aligned}
& .0 \\
& .0 \\
& .0 \\
& .0 \\
& .8 \\
& .0 \\
& .0 \\
& .0 \\
& .0 \\
& .6 \\
& .0 \\
& .0 \\
& .5 \\
& .2
\end{aligned}
$$$$
\begin{aligned}
& .0 \\
& .0 \\
& .0 \\
& .0 \\
& .0 \\
& .0 \\
& .2 \\
& .1 \\
& .0 \\
& .0 \\
& .0 \\
& .0 \\
& .0 \\
& .0 \\
& .0 \\
& .0
\end{aligned}
$$$$
\begin{array}{ll}
.0 & .0 \\
.0 & .0 \\
.0 & .0 \\
.0 & .0 \\
.0 & .0 \\
.0 & .0 \\
.2 & .0 \\
.1 & .0 \\
.0 & .0 \\
.0 & .0 \\
.0 & .0 \\
.0 & .0 \\
.0 & .0 \\
.0 & .0 \\
.0 & .0 \\
.0 & .0 \\
.1 & .0 \\
.1 & .0 \\
.1 & .0 \\
.0 & .0
\end{array}
$$$$
\begin{aligned}
& .000 \\
& .000 \\
& .000
\end{aligned}
$$$$
.000
$$$$
.506
$$$$
\text { - } 000
$$$$
\text { -.000 }
$$$$
\text { .000 }
$$$$
\text { -c0o }
$$$$
.000
$$$$
.200
$$$$
.000
$$$$
\text { - CCE }
$$$$
.000
$$$$
.000
$$$$
.000
$$$$
.000
$$$$
.000
$$

146.8

168.9

11.9

113.9

$12 \cdot 2$
$134 \cdot 1$

134.1
14.3

$294 . C$

15.5
167.2

167.2

163.7

17.4

263.4

17.4

175.2

189.6

20.3

6.505

2.121

15.9

163.6

136.1

19.9

5.449

1.903
5.865

5.865
1.978

1.978
7.193

$\begin{array}{rr}22.2 & 2.235 \\ 204.9 & 7.645\end{array}$

7.645

21.9

2.257

9.301

23.5

2.644

$2: 0.2$

9.25,3

2.901
8.579

237.7

17.6

25.1

2.495

238.1

3.673
6.5
7.4
.000

. ODC

. 000

.000
.000

.003

. 000

.002

- 020

.000

.000
.005

.000

-ces

.002

.000

- COC

.020
.050

.000

$.0 C C$
$.0 O S$

.000

5.891

1.677

. 020

.000

.000

.020

.000

22.073

3.236

3.959

.050

.000 
ABSOLUTE NUCLIDE AETIVITIES AND COMPOSITE BURNUP

FLEL IDENTIFICATION

GA. AXIAL SCAN

TAG COR

NO. LOC. INTERVAL

$126 \quad 1547.68 \quad 76.94$

AUTO $\$: 9$ E14-01

$127 \quad 2640.23 \quad 95.27$

AUTO :20 E24-C1

$128 \quad 1730.06 \quad 73.48$

AUTO $=21$ E $14-51$

$129 \quad 1811.71 \quad 78.94$ AUTO $422 \leq 14-01$

$130 \quad: 896.77 \quad 83.02$ AUTO W23 El4-01

$131 \quad 1985.25 \quad 83.02$ AUTO $=24$ E:4-31

$132 \quad 2075.07 \quad 85.74^{\circ}$ AUTC $\div 25$ E14-01 $2332164.90 \quad 83.02$
AUTO 26 E14-0!

$134 \quad 2252.68 \quad 81.66$

(2) AUTO $=27$ E14-C:

$1235 \quad 2341.24 \quad 84.38$

AUTO $\neq 28 E 14-01$

$136 \quad 2430.78 \quad 84.38$

$37 \quad 2525.81 \quad 84.38$ AUTO $=35 E \$ 4-01$

$138 \quad 2611.99 \quad 87.11$ AUTO \#31 E14-01

$139 \quad 276: .81 \quad 81.66$ AUTO 32 [14-01

$1402789.60 \quad 83.02$

AUTO 233 E14-E1 1412873.98 E 77.58
AUTO 34 E14-01

* stpata zelu-0l rotals

UT MEAN = 128.0

HT I SIGMA $=45.2$

WT RMSS $=5 \mathrm{~J} .7$

HT ERROR = 10.4

* eegin strata $3 * * *$

$143 \quad 3048.22 \quad 85.74$
AUTO $\$ 36$ EI4-OI
NUCLIOE CIIS +1- I SIGMA ERROR

$\begin{array}{ll}C E-144 & C E-141 \\ 133 K E V & 145 K E V\end{array}$

83.1 99.7

12.5

117.5

24.8

23.5
157.7

14.1

$155 \cdot 7$

13.8

96.1

12.0

131.5
14.2

14.2

13.6

104.6

15.4

92.5

13.1
06.6

05.6
12.7

88.9

$12 \cdot 3$

83.6

13.7

61.7

3.5

73.7

$1: 05$

72.1
11.3

$4 * 4$

$89.7 \quad 8: 7.1$

12.7

16.1

$2 \cdot 5$

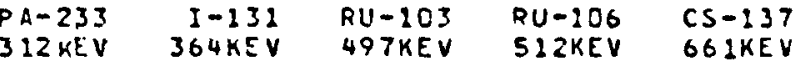

$9: 2.7$

100.3

90.6

$162 \cdot 1$

977.1

100.7

994.2

$102 \cdot 5$

83.9

$79 \cdot 5$
972.3

103.4

964.5

99.6

937.0

96.6

876.2

$821 \cdot 1$

84.8

778.6

80.6

714.3

652.0

63.7

6.57 .8

63.3

45.9

273.4

17.3

.3

\begin{tabular}{|c|c|c|}
\hline $\begin{array}{l}66.3 \\
13.0 \\
93.7 \\
20.6 \\
62.1\end{array}$ & $\begin{array}{r}60.3 \\
6.6 \\
62.2 \\
6.9 \\
63.7\end{array}$ & $\begin{array}{r}8.8 \\
6.5 \\
.0 \\
13.0\end{array}$ \\
\hline $\begin{array}{l}12.3 \\
93.1 \\
16.1\end{array}$ & $\begin{array}{r}7.1 \\
66.7 \\
7.4\end{array}$ & $\begin{array}{r}8.2 \\
20.9 \\
7.0\end{array}$ \\
\hline $\begin{array}{l}54.6 \\
11.4 \\
81.0 \\
14.5\end{array}$ & $\begin{array}{r}53.5 \\
6.4 \\
66.2 \\
7.3\end{array}$ & $\begin{array}{l}.0 \\
.0 \\
.0 \\
.0\end{array}$ \\
\hline $\begin{array}{l}65.8 \\
14.7 \\
95.9 \\
21.6 \\
63.6\end{array}$ & $\begin{array}{r}53.6 \\
6.2 \\
52.2 \\
6.1 \\
66.7\end{array}$ & $\begin{array}{r}12.5 \\
7.1 \\
20.4 \\
6.7 \\
36.3\end{array}$ \\
\hline $\begin{array}{l}14.3 \\
65.5 \\
15.7\end{array}$ & $\begin{array}{r}7.4 \\
55.9 \\
6.6\end{array}$ & $\begin{array}{r}8.1 \\
57.0 \\
9.9\end{array}$ \\
\hline $\begin{array}{l}49.9 \\
11.9\end{array}$ & $\begin{array}{r}6 i .2 \\
6.8\end{array}$ & $\begin{array}{l}47.7 \\
20.2\end{array}$ \\
\hline 48.1 & 56.7 & 52.6 \\
\hline $\begin{array}{l}15.6 \\
45.2 \\
11.2\end{array}$ & $\begin{array}{r}6.5 \\
55.1 \\
5.4\end{array}$ & $\begin{array}{r}9.7 \\
47.2 \\
10.0\end{array}$ \\
\hline $\begin{array}{l}56.0 \\
22.0\end{array}$ & $\begin{array}{r}54.7 \\
6.2\end{array}$ & $\begin{array}{l}56.3 \\
10.2\end{array}$ \\
\hline 34.3 & 50.4 & 51.6 \\
\hline $\begin{array}{l}20.9 \\
35.8\end{array}$ & 5.9 & $\begin{array}{r}8.3 \\
71.5\end{array}$ \\
\hline $\begin{array}{l}35.6 \\
12.1\end{array}$ & $\begin{array}{r}41.6 \\
5.1\end{array}$ & $\begin{array}{l}71.5 \\
11.6\end{array}$ \\
\hline 62.2 & 56.2 & 33.9 \\
\hline $\begin{array}{l}14.2 \\
17.5\end{array}$ & $\begin{array}{l}6.4 \\
7.9\end{array}$ & 8.4 \\
\hline 2.8 & 2.3 & 2.1 \\
\hline $\begin{array}{l}.0 \\
.0\end{array}$ & .0 & $\begin{array}{r}56.9 \\
7.2\end{array}$ \\
\hline
\end{tabular}

15.8

2.2
17.9

2.2

2.2
17.6

2.2

15.4

2.0

2.2

14.2

1.9
24.9

1.9

26.5

2.2

13.7

1.9
13.7

13.7
1.9

14.9

13.9

2.8

2 .

10.2

1.0
8.1

2.3

19.0

19.0

2.7

. .5

$Z R-95$ $724 K E V$

185.4

18.6

177.3

18.8

181.8

29.2

190.5

179.2

19.0

182.7

19.4

162.5

19.4

383.1

19.6

165.4

167.2

18.0

158.5

17.5

244.2

15.5

145.3

25.7

132.6

14.3

12.9

161.7

$261 \cdot 7$
17.5

17.5
24.2

3.5

$: c$
CS -134 $796 K E V$

19.3

19.3
2.3

29.4

2.3

2.2

2.7

23.

2.5

2 .

17.

2.1

2.0

17.

2.2

2.2
12.9
1.7

16.

2.

11.4

2.5

1.5

$1 \cdot 5$

3.3

7.3

1.1

$7 \cdot 2$

1.1

23.9

2.9
2.9

5.1

$: 0$

COMPOSITE

FIMA

LA-140 CS-1 27 RU-1C6 SKEV

25.3

251.2

25.7

25.7

$25: .3$

26.6

242.7

25.8

25.9

229.5

24.3

244.2

25.9

244.1

223.9

25.8

$2: 6.7$

$23 \cdot 1$

198.7

21.2

293.8

275.4

27.4

172.1

28.4

163.1
17.7

9.444

2.991

5.854
2.270

2.705

9.397

2.852

10.494

2.917

9.186

10.346

2.966

8.464

2.542

8.877

2.605

2.386

8.157

2.510

8.155

2.585
6.914

2.715

7.081

2.409

7.955

5.708

5.993
2.125

4. 837

1.711

215.4

8.345

23.1

2.594

1.640

.520

29.332

4.6 
ABSOLUTE NUCLIDE ACTIVITIES AND COMPOSITE BUDNUP

FUEL IDENTIFICATION

GA. AXIAL SCAN

TAG C.ORE INTERVAL

NO.

$144 \quad 3134.63 \quad 76.22$ AUTO 37 E24-01

RATA 3 E14-01 TOT STRATA 3 E14-01 TOTALS WT MEAN = WT 2 SIGHA WT RMS

0
.0

WT ERROR =

- eegir strata a $45 \quad 2516.76 \quad 1.00 \quad 060$ STAT I E $14-01$ $14618 C 4.211 .00$ STAT E2 E:4-C $197 \quad 1820.67 \quad 1.0 \mathrm{C}$ STAT \# E14-01

$1481837.16 \quad 1.00$ STAT 4 E $14-C 2$

$1492853.64 \quad 1.00$ P STAT DS E14-01 2070.10 1.0C STAT 6 [14-01

$151996.90 \quad 1.00$

STAT 239 E $14-01$ 1.00

TRAP ELL-DI

TRATA HEI4-01 TOTALS

HT MEAN = 20503

LT I SIGMA = $190 \mathrm{C}$

WT RMS $=17$.

WT ERROR =

7.18
NUCLIDE CII) +1- I SIGMA ERRUR

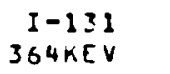

$R U-103$

SU $-1 C 6$

$\operatorname{cs}-137$

t6IKEV

$Z R-95$

$24 K F V$

.3
.3
.0
.0
.0

.2

. C

.0

2.4
6.5

.0

.0

. .0

.

.0
.5
-5

.0
.0
.0
.0

54.8

6.9

2.3

.0
.0
.0
.0

60.2

8?.9 753.8

3.8
163.0

2.0
11.2

40.7

1C.?

94.6

10.2

$1 \mathrm{C5} \cdot 2$

11.4

110.5

12.0
82.0

82.0

8. 8

is

96.7

10.0

10.0
9.8

4.5

77.5

956.4

$96 \cdot 2$

99.4

971.3

99.7

959.4
98.5

1698.0

112.7

757.7

77.8
. .2

.0

923.6

95.6

115.5
36.1

8.6
61.6

61.6
7.9

73.8

9.2

73.9

9.7
62.7

62.7
8.5

74.4
9.6

9.6

34.7

8.3
.0

58.0

6.1
62.3

62.3

6.5
64.3

6.7

63.7

5.6

65.3
6.8

75.1

7.3

6.. 1

6.3
.0

.0

51.4

6.1
12.3

2.8

7.8

2.1

2.1

14.0

2.9
12.8

12.8
2.8

11.7

2.8
.3

12.1

1.3
10.5

1.8
16.5

1.8

17.7

1.9

17.3
2.9

20.2
2.2

13.7

1.5
.5
.1

67.3

8.7
5.9
3.3

63.3

3.6

26.7

16.7
3.3
14.4

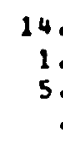

14.3
1.7
5.7
.6

1.3

TO TA L

r

WT MEAN $=119.0$

WT ERROR =

119.0

50.7

88.7.817.1

$12.7 \quad 86.3$

$\begin{array}{rr}26.1 & 173.4 \\ 2.5 & 17.3\end{array}$

62.1
14.1
17.5

55.2

6.4
7.9

1.3

33.9
8.4
20.1
2.1

14.0
1.9
2.7
.4

$17 \cdot 5$
$24 \cdot 2$

3.5

154.8

173.5

17.9

175.6

18.1

17.

177.5

18.3

21.

157.4

16.2

. $\mathrm{C}$

173.9

18.0
15.6

6.8

2.8

$\sqrt{2}$
COMPOSITE
FIMA
$05-134$ CS

796KEV 1596KEV MONITOR RONITOR

$\begin{array}{llll}.0 & .0 & .000 & .000 \\ .0 & .0 & .000 & .000\end{array}$

$.0 \quad .0$

.0
.0
.0

10.8

1.2

19.3

20.0

2.1

18.8

2.0

18.1

1.9
20.0

$2 \cdot 1$
10.4

2.1 .4
1.2

.0

\section{6.}

16.8
1.8
3.9
.7

23.7

9.0

.000

.000

$.000 \quad .000$

. 000 .000

$.000 \quad .000$

36.944

209.3

21.5
224.5

23.2

240.3

$235 \cdot 5$

228.2

23.5

257.1

26.5

213.5

22.0

.0

7.217

1.601
9.854

$2.023 \quad 1.749$

5.994

$2.001 \quad 1.225$

$10.566 \quad 5.129$

$2.196 \quad 1.187$

$10.338 \quad 10.084$

$2.193 \quad 1.900$

$12.062 \quad 9.212$

$2.409 \quad 2.775$

$8.150 \quad 8.405$

$1.769 \quad 1.749$

$\begin{array}{ll}.355 & .000 \\ .108 & .000\end{array}$

8.541

1.910

3.409

12.017

2.189

10.324
.627 


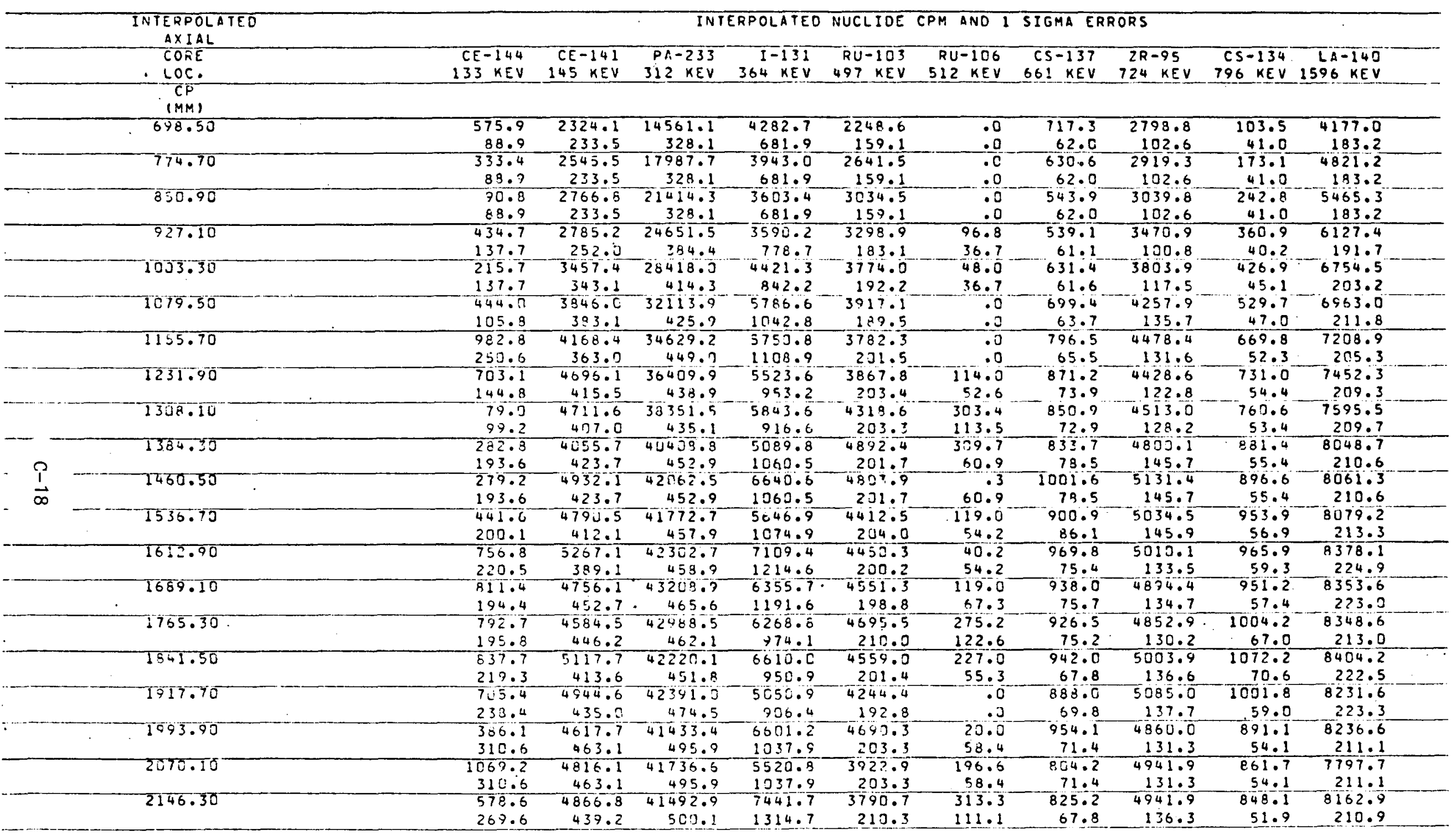




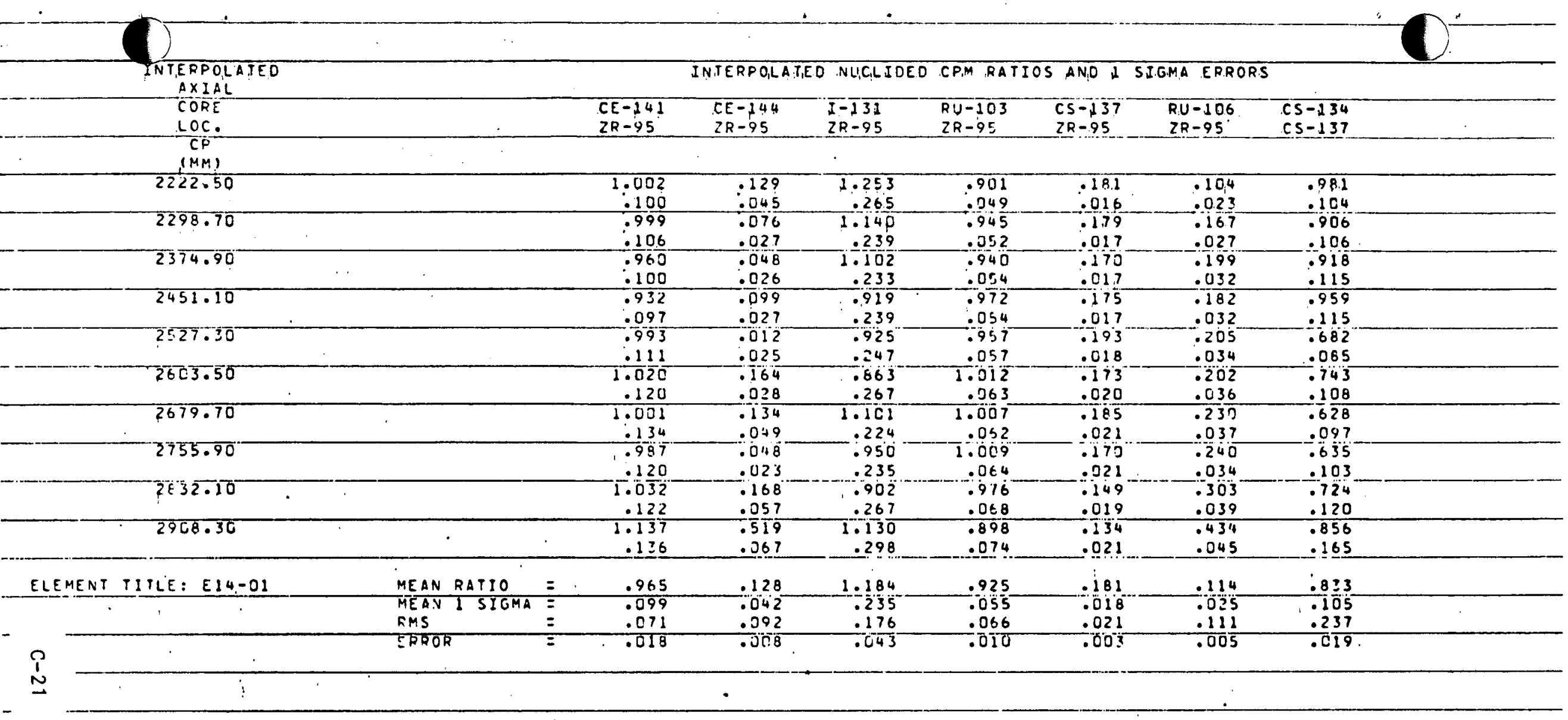




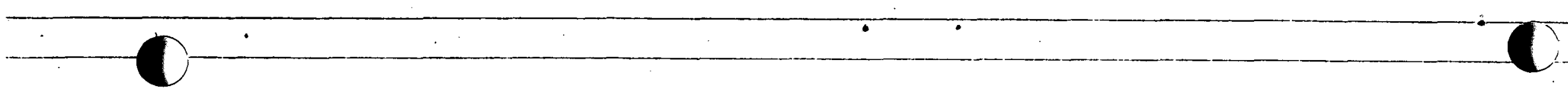

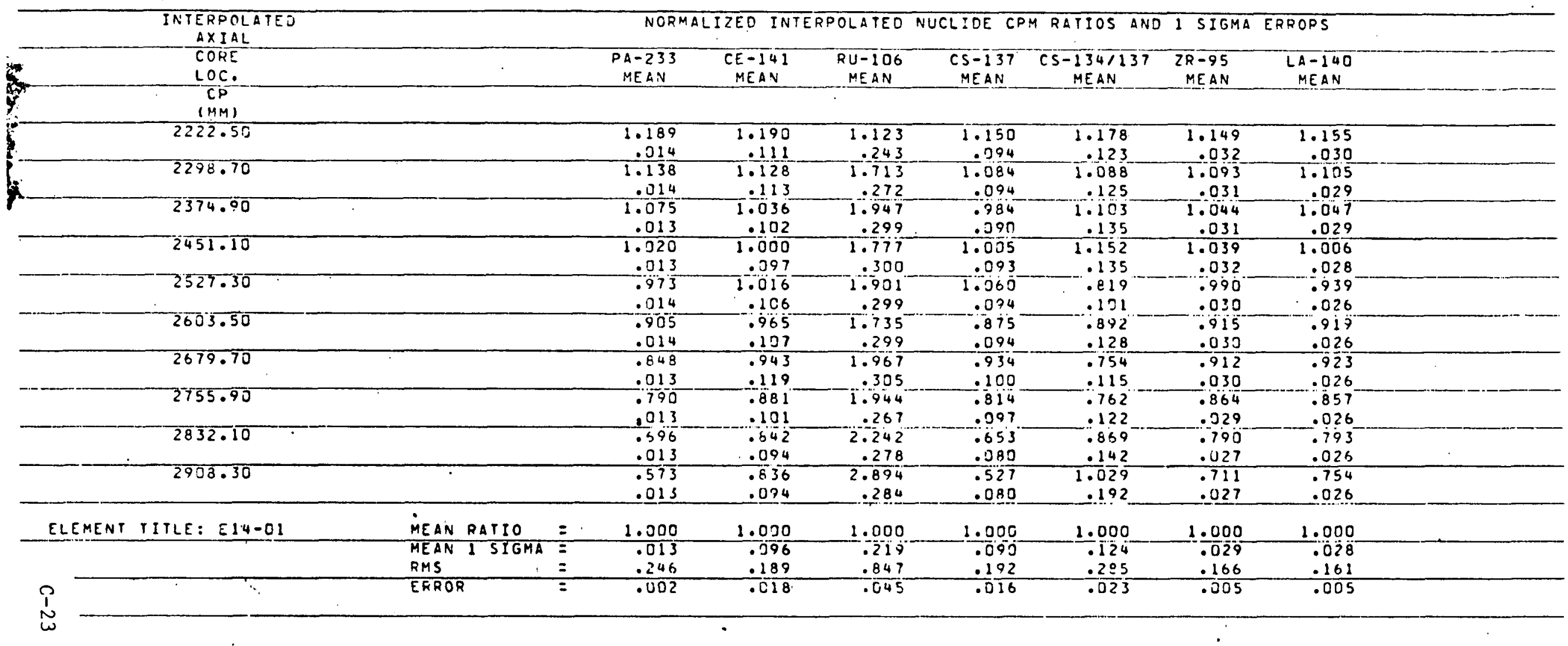


SPECTRUM CORE LOCATION

FUEL ELENENT $I . D$.
NUCLIOE CPM + $1-1$ SIOMA COUNTING ERROR

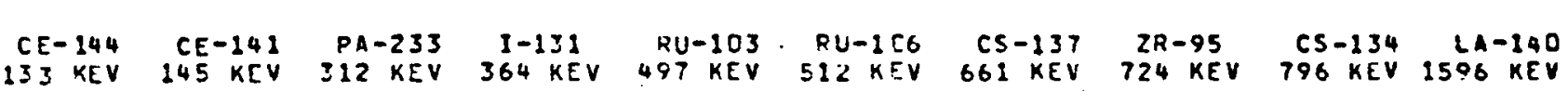

\begin{tabular}{|c|c|c|c|c|c|c|c|c|c|}
\hline $\begin{array}{l}.0 \\
.0 \\
.0 \\
.0\end{array}$ & $\begin{array}{r}27.1 \\
22.0 \\
.0 \\
22.0\end{array}$ & $\begin{array}{r}35.8 \\
18.1 \\
9.6 \\
10.5\end{array}$ & $\begin{array}{r}223.0 \\
92.6 \\
129.9 \\
61.0\end{array}$ & $\begin{array}{l}9.1 \\
5.7 \\
4.3 \\
2.4\end{array}$ & $\begin{array}{l}8.2 \\
3.3 \\
3.2 \\
1.9\end{array}$ & $\begin{array}{r}18.2 \\
9.7 \\
4.0 \\
3.5\end{array}$ & $\begin{array}{r}4.7 \\
2.8 \\
.0 \\
2.8\end{array}$ & $\begin{array}{l}5.8 \\
2.7 \\
4.9 \\
1.9\end{array}$ & $\begin{array}{l}.0 \\
.0 \\
.0 \\
.0\end{array}$ \\
\hline $\begin{array}{l}666.0 \\
241.8\end{array}$ & $\begin{array}{r}4241.4 \\
414.7\end{array}$ & $\begin{array}{r}35 \cap 92.0 \\
448.8\end{array}$ & $\begin{array}{l}5156.9 \\
1029.7\end{array}$ & $\begin{array}{r}4056.8 \\
199.2\end{array}$ & $\begin{array}{l}565.7 \\
123.7\end{array}$ & $\begin{array}{r}783.2 \\
71.5\end{array}$ & $\begin{array}{r}4377.9 \\
130.7\end{array}$ & $\begin{array}{r}693.2 \\
53.6\end{array}$ & $\begin{array}{r}7292.0 \\
206.3\end{array}$ \\
\hline $\begin{array}{r}283.8 \\
55.6\end{array}$ & $\begin{array}{r}769.5 \\
83.2\end{array}$ & $\begin{array}{r}7445.2 \\
90.0\end{array}$ & $\begin{array}{r}1450.2 \\
207.3\end{array}$ & $\begin{array}{r}573.8 \\
39.9\end{array}$ & $\begin{array}{r}335.2 \\
33.9\end{array}$ & $\begin{array}{r}153.9 \\
14.3\end{array}$ & $\begin{array}{r}655.5 \\
26.2\end{array}$ & $\begin{array}{r}254.8 \\
10.7\end{array}$ & $\begin{array}{r}1007.4 \\
41.3\end{array}$ \\
\hline $\begin{array}{l}.0 \\
.0 \\
.0\end{array}$ & $\begin{array}{l}.0 \\
.0 \\
.0\end{array}$ & $\begin{array}{l}.0 \\
.0 \\
.0\end{array}$ & $\begin{array}{l}.0 \\
.0 \\
.0\end{array}$ & $\begin{array}{l}.0 \\
.0 \\
.0\end{array}$ & $\begin{array}{r}915.4 \\
35.5 \\
38.0\end{array}$ & $\begin{array}{l}.0 \\
.0 \\
.0\end{array}$ & $\begin{array}{l}.0 \\
.0 \\
.0\end{array}$ & $\begin{array}{l}.0 \\
.0 \\
.0\end{array}$ & $\begin{array}{l}.0 \\
.0 \\
.0\end{array}$ \\
\hline .0 & $\cdot \mathrm{D}$ & .0 & .0 & .0 & 47.3 & .0 & .0 & .0 & .0 \\
\hline $\begin{array}{r}589.4 \\
86.9 \\
95.6 \\
32.8\end{array}$ & $\begin{array}{r}4625.9 \\
177.2 \\
470.2 \\
67.0\end{array}$ & $\begin{array}{r}39564.9 \\
195.8 \\
496.3 \\
74.0\end{array}$ & $\begin{array}{r}5588.3 \\
434.3 \\
492.1 \\
164.2\end{array}$ & $\begin{array}{r}4573.8 \\
83.6 \\
261.8 \\
31.6\end{array}$ & $\begin{array}{r}279.4 \\
40.8 \\
240.0 \\
15.4\end{array}$ & $\begin{array}{r}802.6 \\
30.5 \\
319.9 \\
10.6\end{array}$ & $\begin{array}{r}4739.2 \\
55.0 \\
422.2 \\
20.8\end{array}$ & $\begin{array}{r}837.8 \\
24.4 \\
196.5 \\
9.2\end{array}$ & $\begin{array}{r}7772.9 \\
84.4 \\
519.3 \\
31.9\end{array}$ \\
\hline
\end{tabular}

TOTALSTTRATA E I 4 - O I

MEAN $=1818.11$
RMS $=630.49$
MIDPT $=1833.15$
RANGE $=2159.25$

UT MEAN CPM =

WT MEAN ISIGMA=

WT RMS

WT ERROR

$666 . C$
241.8
283.8
55.8

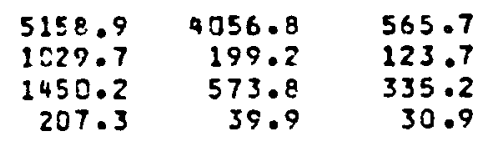

207.3

39.9
783.2
71.5
153.9
14.3
4377.9
130.7
655.5

693.2

53.6

53.6
254.8

7292.0

769.5

7445.2 


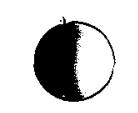

SPECTRUM I.D.

CORE LOCATION

FUEL ELEMENT

GA.TAG AXIAL SCAN

NO. CCRE INTERVAL

LOC.

CP

(MM)

* * STrata l el4-0l totals * *

MEAN $=365.04$ WT MEAN RATIO

RMS $=106.18$

MIDPI $=339.11$

RANGE = $356.0 \mathrm{C}$

E14-01 TOTALS \# \#

MEAN = 1818.11 WT MEAN RATIO

RMS $=635.48$

PIOPT $=1833.15$

RANGE = 21E9.25 3 SIRATA 3EI4-OI TOTALS EFROR

MEAN = 3C91.42 WT MEAN RATIO

RMS = 43021

RMS $=$

MIDPT $=$

RANGE

- STRATA

MEAN $=1617.31$

I PAS $=\quad 645.94$

M MIDPT $=1377.90$

RANGE $=-2276.72$

MEAN $=2818.11$
FMS $=630.49$
MIDPT $=1833.15$

MIDPT $=1833.15$

RANGE $=2159.25$ WT PMS

4 EI4-OL TOTALS

WT MEAN RATIO

WT MEAN 1 SIGHA =

WT RNS

HT ERROR

WT RMS

WT ERPOR

$C E-141$
$Z R-95$

.000
.020
.000
.060
.967
.100
.085
.020
.000
.000
.000
.600
.982
.040
.043
.025

$C E-144$ ZR-95

$$
\begin{aligned}
& I-131 \\
& Z R-95
\end{aligned}
$$

$$
\begin{aligned}
& R U-1=3 \\
& 2 R-95
\end{aligned}
$$$$
\text { CS }-137
$$$$
2 \mathrm{R}-95
$$

$R U-106$ $2 R-95$

$c s-134$

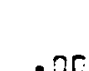

-000
-050

.000

.500

.151

.057

.072
.023

.243

.030
.030

.0 .000

.300
.050

.125
.019
.015

$$
\begin{array}{r}
.000 \\
.000 \\
.000 \\
.000 \\
1.169 \\
.237 \\
.228 \\
.048 \\
.000 \\
.002 \\
.020 \\
.000 \\
1.190 \\
.095 \\
.091
\end{array}
$$$$
\begin{aligned}
& 3.498 \\
& 3.280
\end{aligned}
$$$$
\begin{array}{r}
3 .-80 \\
.250
\end{array}
$$$$
\begin{aligned}
& 3.675 \\
& 2.581
\end{aligned}
$$$$
.050
$$$$
2.581
$$$$
\text { J.C8C }
$$$$
\begin{array}{r}
.178 \\
.018
\end{array}
$$$$
.018
$$$$
\begin{array}{r}
.018 \\
.004
\end{array}
$$$$
\text { . } 255
$$$$
.278
$$$$
\text { . C1: }
$$

. 204$$
\text { . }
$$$$
\text { -cco }
$$$$
.000
$$$$
\begin{aligned}
& .000 \\
& .200
\end{aligned}
$$$$
\begin{aligned}
& . .000 \\
& .200
\end{aligned}
$$$$
\text { .cos }
$$

.193

.007

.974

$.0 \geq 3$
.028

.016

.003

$\begin{array}{ll}.000 & .524 \\ .000 & 1.185 \\ .000 & .490 \\ .000 & .007 \\ .137 & .659 \\ .030 & .105 \\ .096 & .208 \\ .007 & .021 \\ .000 & .000 \\ .000 & .000 \\ .050 & .000 \\ .000 & .000 \\ .062 & .909 \\ .009 & .043 \\ .059 & .127 \\ .053 & .026\end{array}$

TOTAL

STRATA E I A - O I

WT MEAN RATIO = 967

WT MEAN I SIGMA $=\quad .100$

$\begin{array}{rl}1.169 & .932 \\ .237 & .255 \\ .228 & .078\end{array}$

$\begin{array}{ll}.048 & .078 \\ & .011\end{array}$
.178
.028
.016

.016
.004
.137
.033
.096

.096
.037
.859

.105 .208 


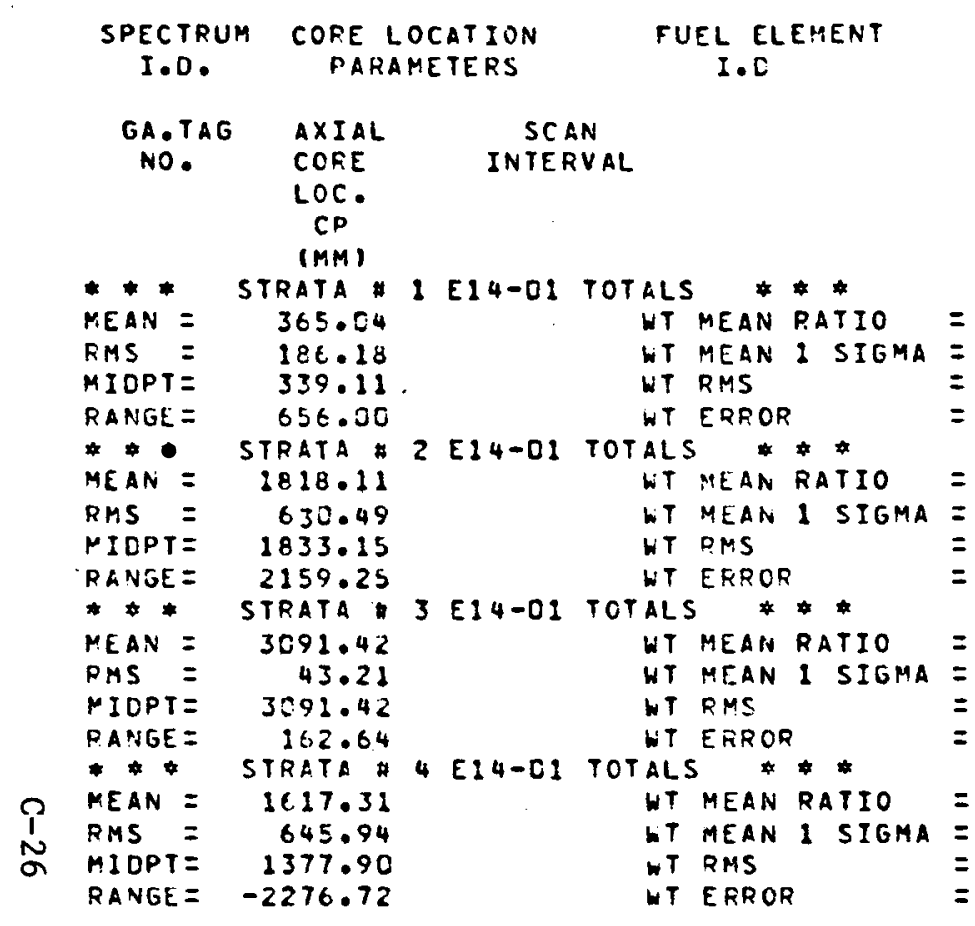

$P A-233$ MEAN

CE-14 MEAN

$R U-106$ MEAN

\section{.00}

- CCI

- EDC

- CCC

1. 000

.013

. COI

- cos

ספטים

סטن

ס00

1. 130

. 305

.325

.002

\section{.006}

.005

- 000

.055

\section{.015}

.006

- ccs

1.000

.096

1.000

.212

.019

0.053

.023

- 212

- Cट5

.004

.609

.652
.570

.445

1.

.389

.197

1.000

.120

.242
.024

$\begin{array}{rr}.060 & 1.618 \\ .000 & .042\end{array}$

- 500

ספנ.

.300
.090

.050
.000

.000

$.020 \quad .030$
1.091
- 41

.494

.075

\section{023}

.038

.408

.408
.014

.000

.000

. . 00

1.057

.049

.148

.018

TOTAL STRATA E14-01

MEAN $=1818.11$
RMS $=632.49$
MIOPT $=1833.15$
RANGE $=2159.25$

WT MEAN RATIO
WT MEAN I SIGMA $=$
WT RMS
WT ERRCR

1.000

.013

.212

.003

2.000
.096
.191
.219
1.000
.089
.197
.028

$\begin{array}{ll}.001 & .000 \\ .001 & .000 \\ .000 & .000 \\ .001 & .000 \\ 1.000 & 1.000 \\ .029 & .028 \\ .150 & .138 \\ .006 & .006 \\ .000 & .000 \\ .000 & .000 \\ .050 & .000 \\ .000 & .000 \\ 1.076 & 1.066 \\ .012 & .011 \\ .096 & .071 \\ .055 & .004\end{array}$

1.020
.029
.150
.026

1.000

.028

.138
.006 
ABSOLUTE NUCLIOE ACTIVITIES AND COMPOSITE BURNUP

FUEL IDENTIFICATION

GA. AXIAL SCAN

TAG CORE INTERVAL CE-144

NO. LOC. IJSKEV

$145 K E V$

$$
\text { NUCLIDE CII) }
$$

$P A-233$

$1-131$

$364 k E V$

$R U-103$

1 SIGMA EFROR

* * strata l elu-oi totals $\begin{array}{ll}\text { WT MEAN }= & .0 \\ \text { WT I SIGMA }= & .0 \\ \text { WT RHS }= & .0 \\ \text { WT ERROR }= & .0\end{array}$ STRATA 2 E14-OI TOTALS $\begin{aligned} \text { WT MEAN } & =119.0 \\ \text { WT I SIGMA } & =45.2 \\ \text { WT RMS } & =50.7 \\ \text { WTERROR } & =10.4\end{aligned}$ STRATA IE14-01 TOTALS

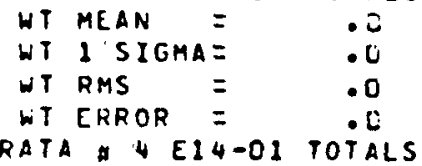
$\begin{aligned} \text { TRATA HEI E } & \text { TOTALS } \\ \text { WT MEAN } & 105.3 \\ \text { WT I SIGMA } & 19.0\end{aligned}$ WT RNS $=17.1$
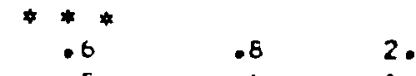

.0

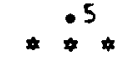

83.7

$83.7 \quad 617.1$

$12.7 \quad 26.3$

$26.1 \quad 173.4$

$+4$

$\begin{array}{ll}.2 & .0 \\ .2 & .0 \\ .0 & .0 \\ .0 & .0\end{array}$

$4 *$

$96.7 \quad 923.6$

$20.6 \quad 95.5$

$\begin{array}{ll}2.7 & .1 \\ 1.2 & .1 \\ 1.6 & .1 \\ .8 & .0\end{array}$

62.156 .2
14.1
17.5

$2 \cdot 8$

.0

.0
.0
.0

.0

67.3

5.9

3.3

$$
\begin{aligned}
& 6.4 \\
& 7.9 \\
& 1.3
\end{aligned}
$$$$
1.3
$$$$
\begin{aligned}
& .0 \\
& .0 \\
& .0 \\
& .0
\end{aligned}
$$

$36 \cdot 1$

63.3

6.6
3.6
2.5
$R U-1.26$
$512 \mathrm{KEV}$

CS -137 GSIKEV

$2 R-95$
$724 K E V$ $796 K E V$

$$
\begin{aligned}
& .5 \\
& .2 \\
& .2 \\
& .1
\end{aligned}
$$

$$
\begin{array}{r}
.3 \\
.2 \\
.1
\end{array}
$$

33.9

8.9
25.1
2.1

14.0

14.0
1.9
2.7

161.7
17.5

59.8
6.9

6.9
2.3
4.9

.0
.0
.0
.0

16.7

36.3
14.4
1.3

14.3

1.7
5.7
.6$$
\begin{array}{r}
.2 \\
: 1 \\
: 1 \\
.1
\end{array}
$$

17.5
24.2

$$
\begin{aligned}
& .1 \\
& .1 \\
& .1 \\
& .0
\end{aligned}
$$

33.9

5.2

.

.0

173.9

$28 .=$

15.6
6.8

\section{8}

1.8

\begin{tabular}{|c|c|c|c|}
\hline $\begin{array}{l}\text { WT } \\
\text { WT } \\
\text { WT }\end{array}$ & $\begin{array}{l}\text { MEAN } \\
\text { I SIGMA } \\
\text { RHS }\end{array}$ & $\begin{array}{l}= \\
= \\
=\end{array}$ & $\begin{array}{r}119.0 \\
45.2 \\
50.7\end{array}$ \\
\hline & ERR OR & $=$ & 10.4 \\
\hline
\end{tabular}

3.9
.7

TOTAL

S T R A T A

E 14-01

$\begin{array}{rr}88.7 & 817.1 \\ 12.7 & 86.3\end{array}$

$22.7 \quad 86.3$

$\begin{array}{rr}26.1 & 173.4 \\ 2.5 & 17.3\end{array}$

\begin{abstract}
$62 \cdot 1$
14.1

17.5
2.8
\end{abstract}

56.2
6.9
7.9
1.3

\begin{abstract}
33.9
\end{abstract}
14.0

161.7

17.5

8.4
20.1

1.9

24.2

23.9
1.9
5.2
.4

215.4

23.1

20.8

8.345

2.394

1.640
.520

$24 \cdot 332$

5.252

14.425

COMPOSITE

CS-137 RU-106

$\begin{array}{rr}.000 & .000 \\ .000 & .000 \\ .000 & .000 \\ .000 & .000 \\ 8.345 & 24.332 \\ 2.594 & 5.202 \\ 1.640 & 14.015 \\ .520 & 1.301 \\ .000 & .000 \\ .000 & .000 \\ .000 & .000 \\ .000 & .000 \\ 8.541 & 12.017 \\ 1.910 & 2.189 \\ 3.409 & 10.324 \\ .6675 & .827\end{array}$




$$
\begin{array}{ccc}
\text { SPECTRUM CORE LOCATION } & \text { FUEL ELEMENT } \\
\text { I.O. } & \text { PAFAMETSRS } & \text { I. O. }
\end{array}
$$

GA.TAG AXIAL SCAN
NO. CCRE LOC. INTERVAL CENTEF POINT INTERVAL CENTER POI$$
\text { * begin statia }
$$

108 49.21 81.66

$109 \quad 178.50 \quad 68.05$

$210 \quad 254.72 \quad$ LUTO \#2 E14-C:

$112 \quad 4: 6.0 \mathrm{C}$

113507.17

$114 \quad 556.86$

115629.00

AUTO \#3 E 14-51
69.41

AUTO \#4 E14-C1

93.91

AUTO :5 E 14-01

.80 .35

AUTO 6 E 14-OI

68.05

AUTO \& 7 E 14-?

76.22

AUTC AB E14-01

$\overbrace{\infty}^{\infty}$

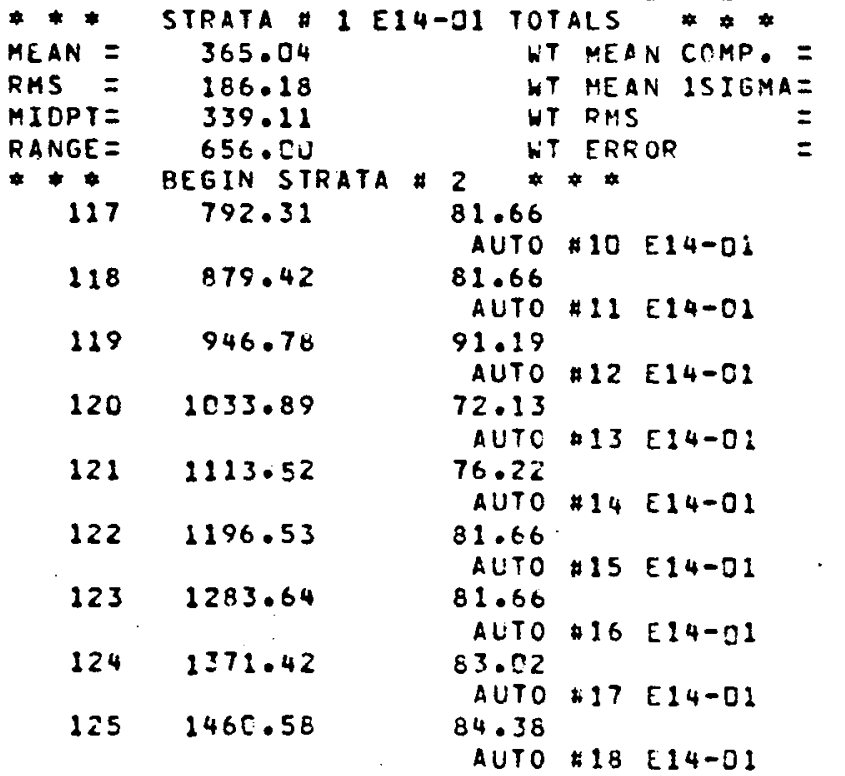

ZR-95 LA14D REL.OIF. COMPARISON

'C.

MEA

MAN

TEST 1

TEST

$D * 2$

FI MA

CS 137

$\begin{array}{ll}\text { FIMA } & \text { REL DIF } \\ \text { RULOS } & Z=-1+C / M\end{array}$

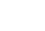

$\therefore$

.000

.005

.

.300
.300

.000
.000

.300

.coa

.000

.200

.500

$.0 \mathrm{CO}$

.001

001

.001

- 251

.300
.001

.673

.025

.755

.329

.024

.990

2.034

.032

1.012

.027
1.010

.028

1.024

.029

1.172
.036

.003
.009
.005
.000
.000
.005
.005
.000
.000
.000
.020
.000
.000
.009
.055
.000
.000
.000
.005
.000
.682
.023
.783
.027
.864
.025
.960
.029
.951
.027
1.025
.028
1.018
.029
1.103
.028
1.105
.029

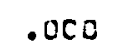$$
.000
$$

$$
\text { - vc0 }
$$$$
\text { - } 200
$$

.005

.000$$
\text { - eco }
$$

- vos

.000

- 000

$$
\text { . } 020
$$

$.00 \mathrm{C}$

.000

.200

.00

. 005

.005

$-.512$

.049

$-100$

.041
. .040

-.040
.039

. .073

.341

.087

.046

.0012
.038

.038
-.087

.039

. .018

.036

.060

.042

.000
.000

.000
.000

- $c 00$

\section{.000}

.003

.000

.500
.050

$.00 \mathrm{C}$

- c.co

- 050

.000

. r.co

.200

. Oce

- coso

. 500

.000

- CCO

.560
.005

- COO$$
\begin{array}{ccc}
0 \\
.020
\end{array}
$$

.000

.

.020

- 600

- 200

.000

.000

.000

- 00

\section{-cro}

- ces

.050
.000

. .250

.000

$-2.424$

.000
-1.026

.000

$-1.753$

.600
1.899

.052
. .326

.000

. .183

.000
. .494

. .494
.000

1.426

1.426
.000
.000

$\begin{array}{ll}.000 & .000 \\ .000 & .000 \\ .000 & .000 \\ .000 & .000 \\ .000 & .000\end{array}$

- $000 \quad .000$

- EDO .JCO

- c00 .000

- EJC .0ट0

- eso

- c5O

- ces

- CCO

-005
.002

.000

.000

.000
.005

.000

.000
.000

-c00

- 500

.000
.005

.005

.000
.000

6.505

2.121

5. 449

1.903

5.865
1.978

1. 978

2. 235

7.645

2. 257

9.351

2. 644

9.253

2. 901

3. 579

2. 495

10.673

3.323
$.00 C$

- Có

.000

5.881

1.877

- OCC

-.00

- 005

-

- ODC

12.073

3.236

15.568

3.959

.000
COMPARISON

$0=2(S(Z) \quad D * * 2$

$.000 .000 \quad .000$

$.000 \quad .020 \quad .003$

.00n .000

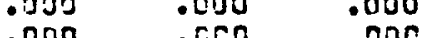

$\begin{array}{ll}.000 & .050\end{array}$

$.000 \quad .000 \quad .000$

$.000 \quad .000 \quad .002$

$\begin{array}{lll}.003 & .000 \\ .000 & .000\end{array}$

.005

.000

- cono

$.000 \quad .020$

$.000 \quad .000$

.000

.000

.000

.000

.000

.000

.000
.003

.000.

.000

.000

.000

.000

.000

.000

$\begin{array}{lll}.000 & .000 & .000 \\ .000 & .000 & .000\end{array}$

.000

.000

.000

.006
.000

.000

.000

.050

.000

.000

.000

-.739
.000

$-2.109$

.005

.000

.000

.000

.000

- 000

.000

.000

.000

000

.000

.546

.000

4.446

.000

.000
.000 


\begin{tabular}{|c|c|c|c|c|}
\hline $\begin{array}{c}\text { SPECTRUR } \\
\text { I.D. }\end{array}$ & $\begin{array}{l}\text { CORE LOCA } \\
\text { PARAMET }\end{array}$ & $\begin{array}{l}\text { ATION } \\
\text { TERS }\end{array}$ & FUE & $\begin{array}{l}E L \text { ELEMEN } \\
\text { I.D. }\end{array}$ \\
\hline $\begin{array}{l}\text { GA.TAG } \\
\text { NO. }\end{array}$ & $\begin{array}{l}\text { AXIAL } \\
\text { CORE LOC. } \\
\text { CENTER POINT } \\
\text { (MM) }\end{array}$ & $\begin{array}{c}\text { SCAN } \\
\text { INTERVAL }\end{array}$ & & \\
\hline 126 & 1547.68 & $\begin{array}{r}78.94 \\
\text { AUTO }\end{array}$ & $\$ 19$ & {$[14-01$} \\
\hline 127 & 1640.23 & 95.27 & & \\
\hline 128 & 1730.06 & 73.49 & 220 & EI4-[1] \\
\hline 129 & 1811.71 & $\begin{array}{r}\text { AUTO } \\
78.94 \\
\text { AUTO }\end{array}$ & $\begin{array}{l}\# 21 \\
122\end{array}$ & $\begin{array}{l}E 14-01 \\
E 14-01\end{array}$ \\
\hline $13 c$ & 2896.77 & 82.52 & & \\
\hline 131 & 1985.25 & $\begin{array}{r}83.32 \\
\text { AUTO }\end{array}$ & $\$ 24$ & $\begin{array}{l}k 14-C 1 \\
E 14-C 1\end{array}$ \\
\hline 132 & 2075.07 & $\begin{array}{r}85.74 \\
\text { A UTO }\end{array}$ & & {$[24-01$} \\
\hline 233 & 2164.90 & $\begin{array}{r}83.02 \\
\text { A UTO }\end{array}$ & 026 & $5=4-0$ \\
\hline 234 & 2252.68 & $\begin{array}{r}81.6 C \\
\text { AUTO }\end{array}$ & $\$ 27$ & {$[14-0]$} \\
\hline 135 & 2341.14 & 84.38 & & \\
\hline 136 & 2430.98 & 84.38 & 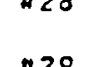 & $=2.4-61$ \\
\hline 137 & 2525.82 & $\begin{array}{r}\text { AUTO } \\
84.38\end{array}$ & 429 & $E 24-51$ \\
\hline 138 & 2611.99 & $\begin{array}{r}\text { AUTO } \\
87 \text {.11 } \\
\text { AUTO }\end{array}$ & $\begin{array}{l}230 \\
.31\end{array}$ & $\begin{array}{l}E 14-0\} \\
E 24-01\end{array}$ \\
\hline 239 & 2702.81 & $\begin{array}{r}81.66 \\
\text { AบTO }\end{array}$ & $* 32$ & E14-01 \\
\hline $29 \mathrm{C}$ & 2789.60 & 83.02 & & 5 \\
\hline 141 & 2873.98 & $\begin{array}{r}77.58 \\
\text { AบTO }\end{array}$ & 234 & $\begin{array}{l}214-01 \\
514-01\end{array}$ \\
\hline $\begin{array}{l}\text { MEAN }= \\
\text { RMS }=\end{array}$ & $\begin{array}{l}\text { STRATA } 2 \text { Z } \\
2818.11 \\
630.49\end{array}$ & $\begin{array}{r}{[14-01 \text { To }} \\
\text { WI } \\
\text { bI }\end{array}$ & $\begin{array}{l}\text { TALS } \\
\text { T. MEA } \\
\text { T MEA }\end{array}$ & $\begin{array}{l}\text { * * * } \\
\text { AN COMP. }=\end{array}$ \\
\hline MIDPT $=$ & $18 \leq 3 \cdot 15$ & 1 & I RMS & 5 \\
\hline $\begin{array}{l}\text { P NGE }= \\
* * * \quad B\end{array}$ & $\begin{array}{l}2159.25 \\
\text { BEGIN STRATA }\end{array}$ & WT & $T$ ERR & $R O R$ \\
\hline 143 & 3048.21 & $\begin{array}{r}85.74 \\
\text { AUTO }\end{array}$ & & $E 24-[1$ \\
\hline
\end{tabular}

2R-9

2R-9S

'C.

LA14J REL.DIF.
MEAN $Z=-1+C / M$

'M.

1.247
.029

1.143

1.108
.029

.029
1.165

$.0 \geq 0$

1.165
.032

1.128

.030

1.224
.328

.028
1.178

.033

1.128

$\therefore .130$

.130
.030

.030
1.128

1.128
1.112

1.152
.033

1.023

.028

1.034
.033

.033
.980

.030

.892

.899

.030

.620

.228

.735

.225

1. $00 \mathrm{C}$

.228

.150

.006

.060
.200

1.167

.029

2.127

0.51

1.136
.029

1. 065

.027
1.134

.029

.029

1. C39

.029

1.006
.029

.029
.923

.026

.920

.026

.907

.026
.799

. 224

.757

.026

1.0.20

.028

.138

.008

.600
.200

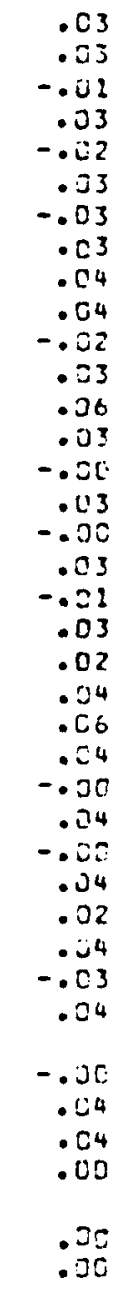

.035
.038
.029
.037
.026
.036
.036
.034
.046
.041
.025
.036
.061
.039
.064
.037
.001
.033
.026
.038
.028
.044
.063
.044
.009
.243
.029
.043
.026
.047
.030
.047
.021
.041
.042
.008
.060
.000

COMPARISIONS OF SELECTED VALUES 2 ITEMS

COMPARISON!

$\begin{array}{ll}\text { TEST } 1 & \text { TEST } 2 \\ 0 Z Z S(Z) & 0 * 2\end{array}$

FIMA

CS: $\mathrm{C}$.

FIMA REL.OIF.

RUIEG $Z=-I+C, M$

COMPARISON

: $M$. $0=z(s, z)$

.922

.850
.070

9.444

5.854

$-.521$

$-000$

. .785
$.00 \mathrm{C}$

$-1.065$

.020

1.129

-0
-.000

$-.752$

1.549

.205

$-.119$

.000
-.03

.031
.000

$-.417$

. .

.0 .70

2.891

10.725

2.968

.616
.000

1.134

.050
1.270

1.276

. C50

.490
.050

2.308

- 000

- 014

- col

-crio

$-174$

- con

.625

$.00 C$
1.416

.050

- $0=0$

2.039

.00
.043

.000

- $0=0$

.200
-.209

- 050

.044

-

.358
.050

.421

.000

$-.633$

.030

1.041

1.018
-.058
.000

1.018

1.018
.060

1.382
.350

2. 892

10.494

2.917

9.186

2.638
10.346

2.966

8.464

2. 542
E. 977

2.606

9.873

2.966

8.157

8. 155

2. 523

8.914

2. 715

2.409

7.055

2. 708

5.093

2. 125

4.837
1.711

$8 . ? 45$

2.594

1.540
.520

.050
.000

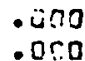

5.854
2.270

- 000

9.910

3.212

15.027

3.710

- 200

- ग00

- Jos

$8.95 \mathrm{C}$

2.925

24.856

3.580

26.094

4033

40.932

34.280

6.546

37.859

6.619
33.881

8.475

40.452

6.994

37.086

5.085

51.336
8.191

24.332

5.202

24.415

14.415
1.301

.005
.000

.000
.000
.613

.013

. OCD

- CCO

-.001
. .459

$-.302$

.260

.230

. cú

.000

.054
.419

$-.398$

.231

$-.622$

.06 .2

.871
.070

. .762

.088

. .764

.083
-.791

.082

$-.803$

.075
-.838

. .838
.063

.0 .26

.037

$-.448$

.310

. 4 10

.428
.077

.789

.769
.000

.030

.000
. .003

.003
.000

$-1.162$

.003

.000

.000

- 0.00

.600
. .130

.000

$-1.705$

.050

$-4.546$

11.465

$-11.465$

$-8.669$

.000

$-9.226$

$-9.699$

.500

$-10.698$

$-10.698$

$-13.356$

.000

-24.776
.000

6

$-6.073$

.000

6.650

.650
.000

.300
.300

.000
.000

$0 * 2$

.592

.

$-000$

$.00 ?$

.000

1.351

.000

- 203

-cos

.000

.027

.000

.000

20.664

.000

231.437

.000
75.147

.000

85.126

.000

94.061

12.450

.000

178.374 


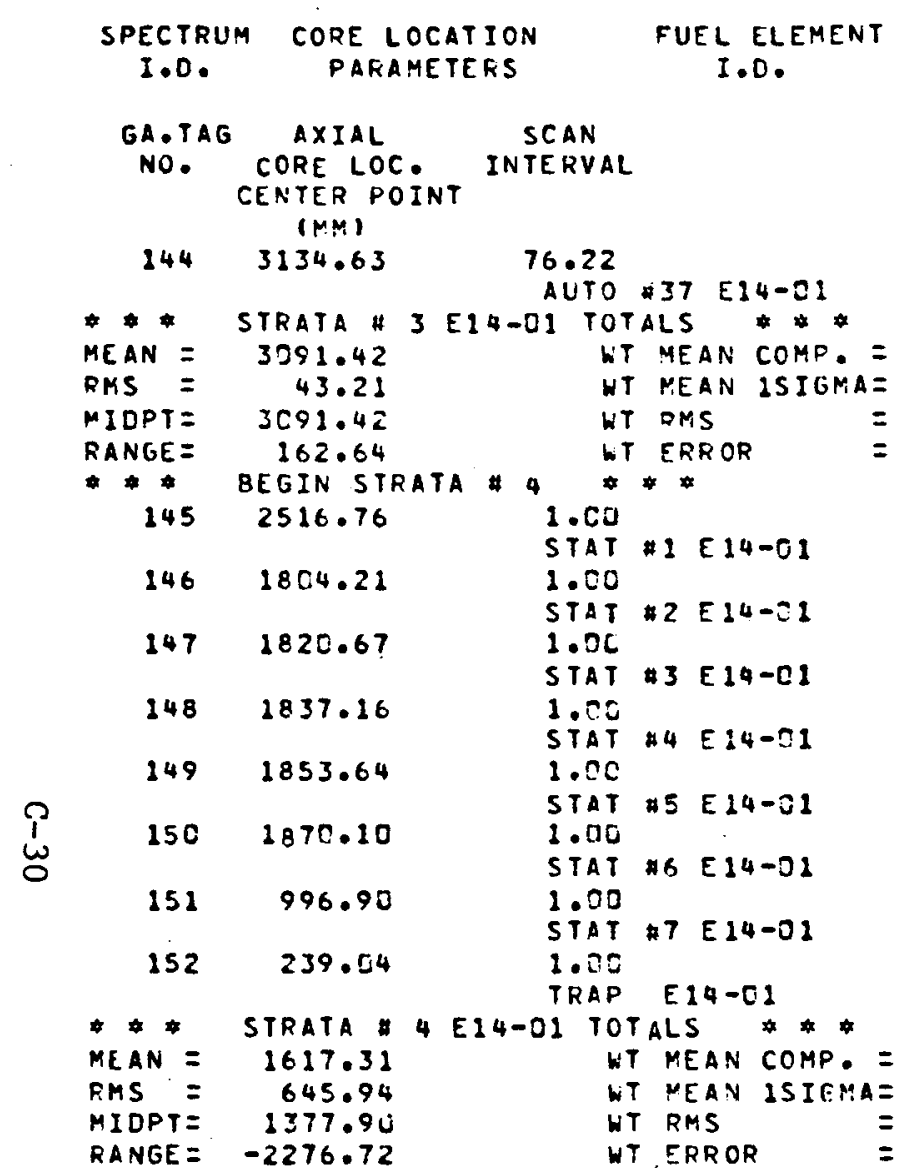

SPECTRUM CORE LOCATION FUEL ELEMENT
I.D.

GA.TAG AXIAL SCAN
NO. CORE LOC. INTERVAL
CENTER POINT

$144 \quad 3134.63 \quad 76.22$

* * STrata 3 eja-0i totals * * *

MEAN = 3091.42 WT MEAN COMP. =

RMS $=43.21$ WT MEAN ISIGMA=

MIDPT $=3 C 91.42$ $=$
$2 D-95$

MEAN

'C.

LAL4C RELODIF
MEAN $Z=-1+C / M$

IM:

.000

.000

.000
.000

.000

.957

.012

1.073

$\therefore 128$

1.086

.012

.012

1. 598

.012

1.275
.014

.014
.973

011

- res

- coa

1.076

.012

.096

.نC5

.000
.005

.000

.000
.500

.000
.005

.967

.011

1.242

.011
1.115

.012

1. 093

.022
1.059

.012

.012
1.194

.012

.99 !

.012

- con

.000

1.066
.011

.011
.071
.004
COMPARISIONS OF SELECTED VALUES E ITEMS
COMPARISON

TEST 2 T.EST 2

$D * \star 2$

.000

.050

.000
.000

.030

.3 .280
.3200

.000

.050

19.218

.050

.000
. sno
. $\mathrm{s}$.

.035

. $\mathrm{JCC}$

.005
.000

$-.016$

.017

.029
.026

$-.027$

.015
-.023

.015

.036

.026

.016

$-.018$

.016

.200
.200

.008
.016

.034
.066
.000

.000
.000

.000

.505

.000
.000

. .609

-.609
.000

1.811

.000
-1.782

.500

$-1.529$

2.220

.000

4.384

.050
-1.130

-1.139
.000

- cco

.480

.480
.000
2.171
.000
FI NA

CS 137

FIMA REL DIF,
RUIDG $Z=-i+C / M$

.372

3.280
.300

.300
3.171

.000
2.337

4.930

.530
2.297

.000
.000

4.944

5.984
.000
.600
.000

' $M$.

\section{.000
.000}

.000

- c00

- $c 00$

.000
.020

7. 517

1. 601

9. 854

2. $C 13$

9.836

2.5 .02

10.566
2.196

10.338

2.290

$2 \cdot 290$
12.662

2. 459

8. 150

1. 759

- $2 \mathrm{CC}$

8. 541

1.910

3.409

.675
.699
-C2C

- 000

.000
.000

36.944

4.213

8.849

1.749

5.494

1.225

5.129

10.084

1.904

9.212

1.775

8.406

1.744

.000

12.017

2.189

10.324

.827
STRATA E I H - O I

MEAN $=1818.11$

RMS $=1818.11$

MIDPT $=18: 8.12$

WT MEAN COMP.

WT MEAN ISIGMA=

WT RMS

1.000

O T A L

$\begin{array}{rr}1.000 & -.001 \\ .028 & .041 \\ .138 & .042 \\ .006 & .008\end{array}$

$\begin{array}{rr}-.058 & 1.041 \\ .000 & .000 \\ 1.018 & 1.382 \\ .000 & .000\end{array}$

8.345
2.594
1.640

24.332

5.202

14.415

-.448
.31
.408
.077

-6.073
.000
6.650
.050

81.110 .000

$.150 \quad .1380401 .02801 .382$

.520

$\begin{array}{rr}.000 & .000 \\ .000 & .000 \\ .000 & .000 \\ .000 & .000 \\ .000 & .000 \\ .000 & .000 \\ -.805 & -16.511 \\ .049 & .000 \\ .114 & .359 \\ .317 & .000 \\ .790 & 1.463 \\ .540 & .000 \\ 1.060 & 1.655 \\ .641 & .000 \\ .025 & .087 \\ .291 & .050 \\ .309 & .851 \\ .353 & .000 \\ . .030 & -.104 \\ .291 & .000 \\ .050 & .000 \\ .000 & .000 \\ .209 & -1.743 \\ .398 & .000 \\ .561 & 6.060 \\ .150 & .000\end{array}$

95.063

.000

\footnotetext{
2818.12
} 


$$
\begin{array}{ccc}
\text { SPECTRUM COPE LOCATICN } & \text { FUEL ELEMENT } \\
\text { I.D. } & \text { PAFAMETERS } & \text { I.D. }
\end{array}
$$

$$
\begin{aligned}
& \text { GA.TAG AXIAL SCAN } \\
& \text { NO. CORELLC. INTERVAL } \\
& \text { CENTER POINT } \\
& \text { (MHI) }
\end{aligned}
$$

* * Begin strata y 1 * * *

$209 \quad 178.50$

AUTO 1 E14-2

68.05

AUTO $2 \simeq 14-01$

$110 \quad 254.72$

68.05

$111328.90^{\circ} \quad 69.41$

311 416.00 AUTO
112 93.91 E 14-?1

93.91

AUTO म5 E $14-01$

$113 \quad 507.17$

.80 .35

$114 \quad 556.86$

AUTO म 6 E 24-E1

$114 \quad 556.86$

69.05

AUTO मT E $14-C$ ]

76.22

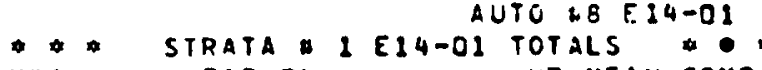

I HEAN $=365.04$ WT MEAN COMP. $=$

$\rightarrow$ RAS $=186.1$

RANGE = 656.11

* bEgIN STRATA

WT RMS LISE =

* begIN STRATa 2

$117.792 .31 \quad 81.66$

679.42

AUTO
81.66

$\begin{array}{rr}129 & 946.78 \\ 120 & 1033.89\end{array}$

AUTO A1 EI4-OI

$121 \quad 1113.52$

$122 \quad 2196.53$

$123 \quad 1283.64$

$124 \quad 2371.42$

1252865.58
91.19

$$
\text { AUTO } 12 \text { E14-O: }
$$

72.13

AUTO 213 E14-OI

76.22

AUTO \#14 E14-DI

B1.66

AUTO \&15 E14-0I

81.06

AUTO IE E:4-O

83.02

AUTO $217514-02$

84.38

AUTO \#IR EI4-OI
CS137 CS4/7 REL.DIF.

MEAN

MEAN $Z=-!+C / A$

COMPARISON

$\begin{array}{ll}\text { TEST 1 TEST } \\ D=Z I S T Z 1 & 0 * 2=2\end{array}$

- $c$

REL.OIF. COMPARISON $Z=-1+C / M \quad T=Z S T 1 \quad$ TEST 2

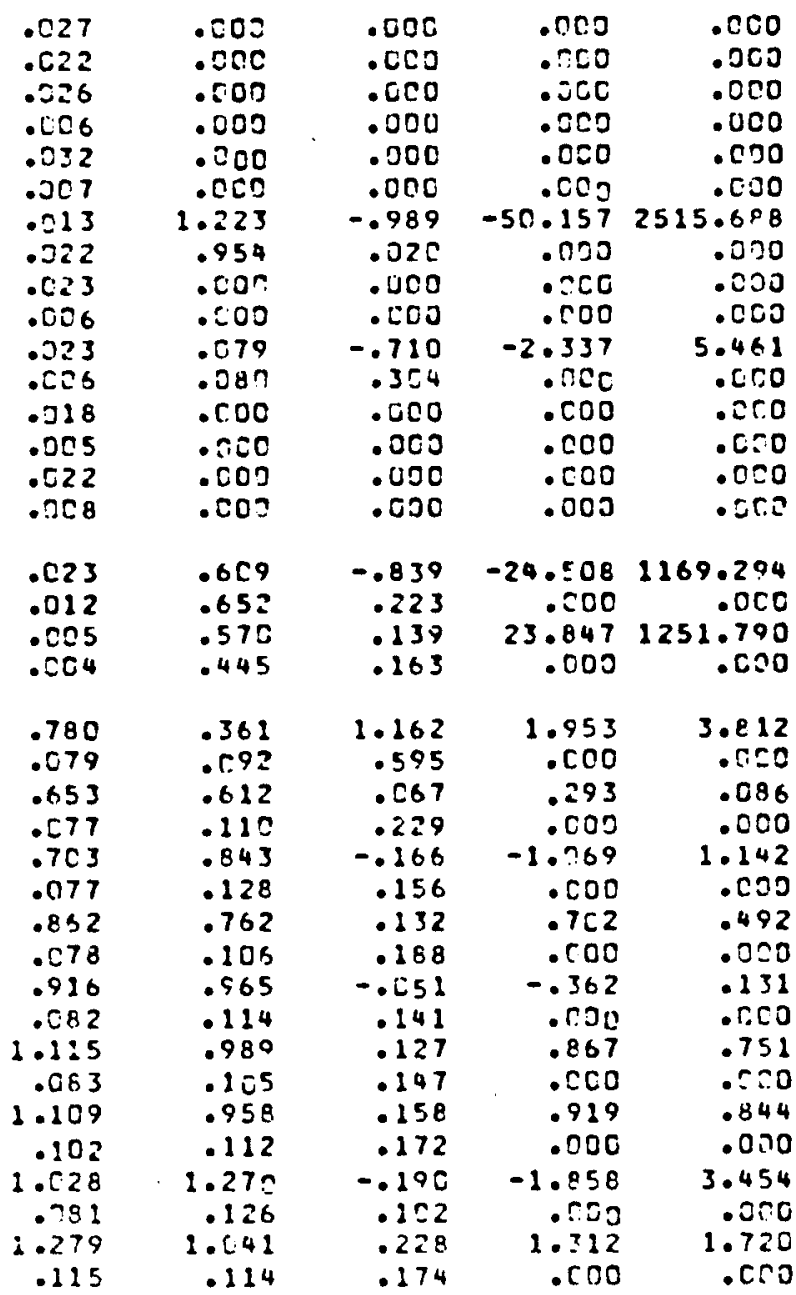


$\begin{array}{ccc}\text { SPECTEUM CORE LOCATION } & \text { FUEL ELEMENT } \\ \text { I.O. } & \text { PAHAMETERS } & \text { I.D. }\end{array}$

\section{GA.TAG AXIAL SCAN}

CENTER POINT

$$
(M, M)
$$

$126 \quad 2547.58$

$127 \quad 164 \mathrm{C} .23$

$128 \quad 1730.06$

$129 \quad 1821.71$

$130 \quad 1896.77$

$131 \quad 1985.25$

$132 \quad 2075.07$

$\$ 33 \quad 2164.90$

1342252.60

$\stackrel{?}{1}$

$135 \quad 2341 \cdot 14$

$136 \quad 2430.98$

$137 \quad 2520.81$

$138 \quad 2611.99$

$139 \quad 2701.81$

$140 \quad 2789.60$

$2412 \varepsilon 73.98$

* strata a.2 el4-0l totals * *

MEAN = 1818.11 WT MEAN COMP. =

RHS $=630.49$

MIDPT= 183 ?

MIDPT 1833.15

RANGE = 2159.25 WTERROR

* begin strata *3

$143 \quad 3048.21$
78.94

A. 27

20 E14-01

AUTO \#21 E14-01

78.94

AUTO :22 E14-01

*23 E14-01

5.74

AUTO \#25 E14-OI

B. 32

1.66

\#27E14-01

84.38

AUTO 28 E14-GI

84.38

AUTO 29 E14-OL

4.38

87.11

\$3 E 24-0I

AUTO \#32 E14-CI

AUTO \#33 E:4-C:

A.

.58

WT MEAN COMP
WT MEAN ISIGMA
WT RMS
WT ERROR
*\#

85.74

AUTO H 36 EI4-Ci
AUTO AI9 E14-01
CS137

MEAN

CS4/7 REL.DIF.

MEAN $Z=-l+C / M$

- $M$.

COSPARISON

1.132

1.599
1.283

1.263

.263
.133

1.123

.105

1.237

1.126

.099

1.258

.089

1.101

.082

1.240

.093

1.014

.085

.064

.085

1.183

.200

.977

.587

.977

.092

$1 . \operatorname{ces}$

.092

.249

004

.953

.205

.718

087

.580

.070

1.000

.589

.107

.518

.000
.000

.130

.290

.129

.131
1.072

.105

1.259

.129

$1.18=$

.118

1.123
.124

.124

.116

.149

.149

.093

.874

.689

.206

.780

.123

.919
.154

1. 000

.120

.242

. 224

.003
.000

$-.843$

1.084

. .716

$-2.246$

.000
COMPARISIONS OF SELECTEO VALUES C ITEMS
$-.104$

.122

.134

. .089

.125

-.025

.119

$-.212$

.094

.157

$-195$

107

-. 099

.125

.054

.147
-.000

.148

$-.198$

.124

.198
-.029

.181

.384

.262

$-.079$

.183

$-.369$

- 1 Ja

.047

.194

.289
.039

.000

.000
REL.DIF •

'c

- $M$ •

.721

$.000 \quad .020$

1.175

.000

.060

.045

00

5.046

.000

1.2:3

$.000 \quad .000$

$-1.824 \quad 3.327$

$-.855$

$.000 \quad .000$

$.365 \quad .133$

- 000 .000

- 000

.000
$-1.602 \quad 2.567$

$.000 \quad 2.567$

$1.700 \quad .060$

2.185

-.161 .ن26

-rOS .0CO

$1.467 \quad 2.151$

$.000 \quad .000$

$-.431 \quad .186$

. $530 \quad .000$

$-2.8318 .017$

$.000 \quad .000$

$\begin{array}{rr}-.121 & 1.659 \\ .000 & .000\end{array}$

$1.282 \quad 1.870$

.0 .870

$\begin{array}{ll}.000 & .000 \\ .000 & .000\end{array}$
$0=2 / S(Z) \quad 0 * 2$
TEST 1 TEST 2 


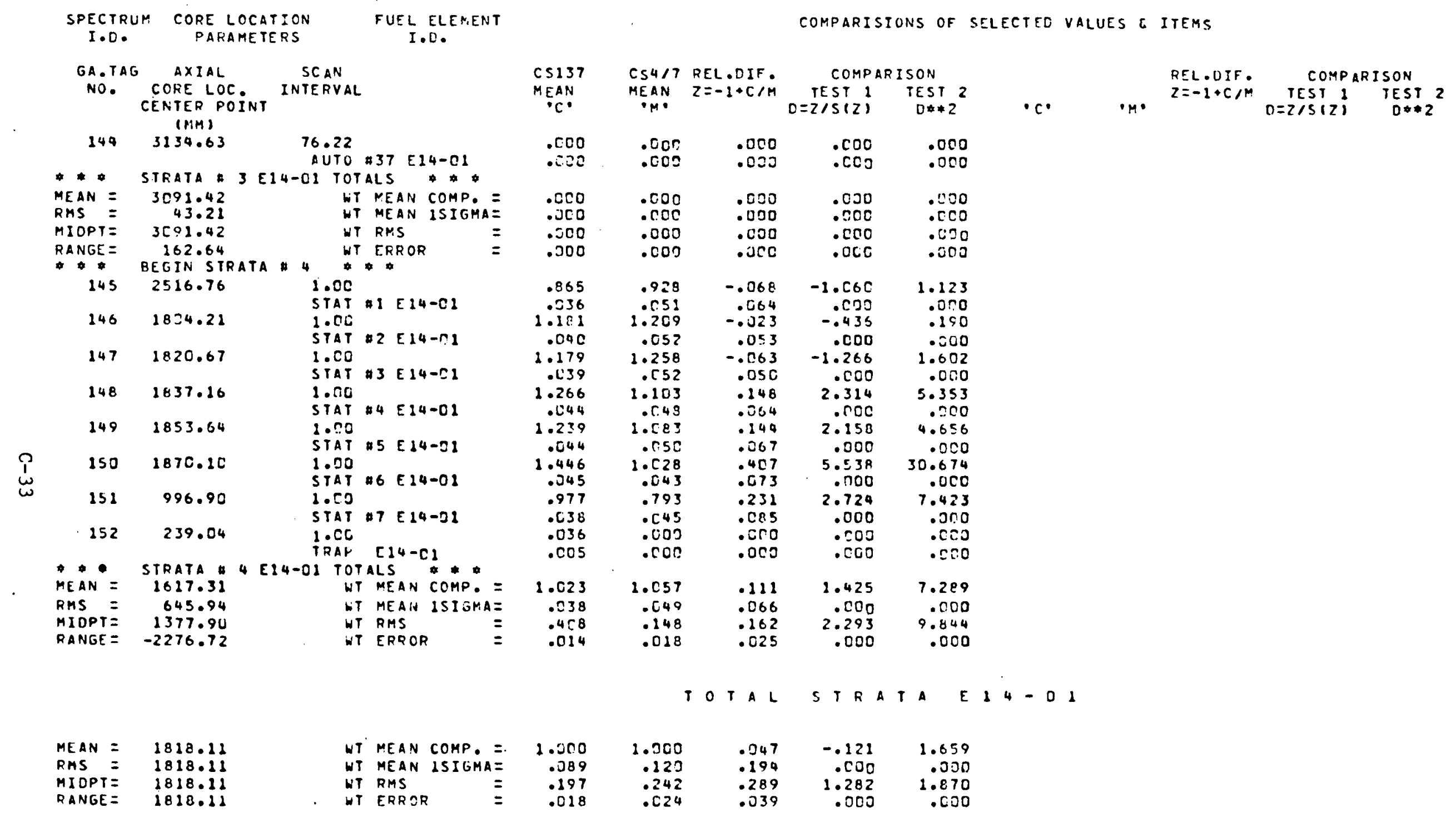




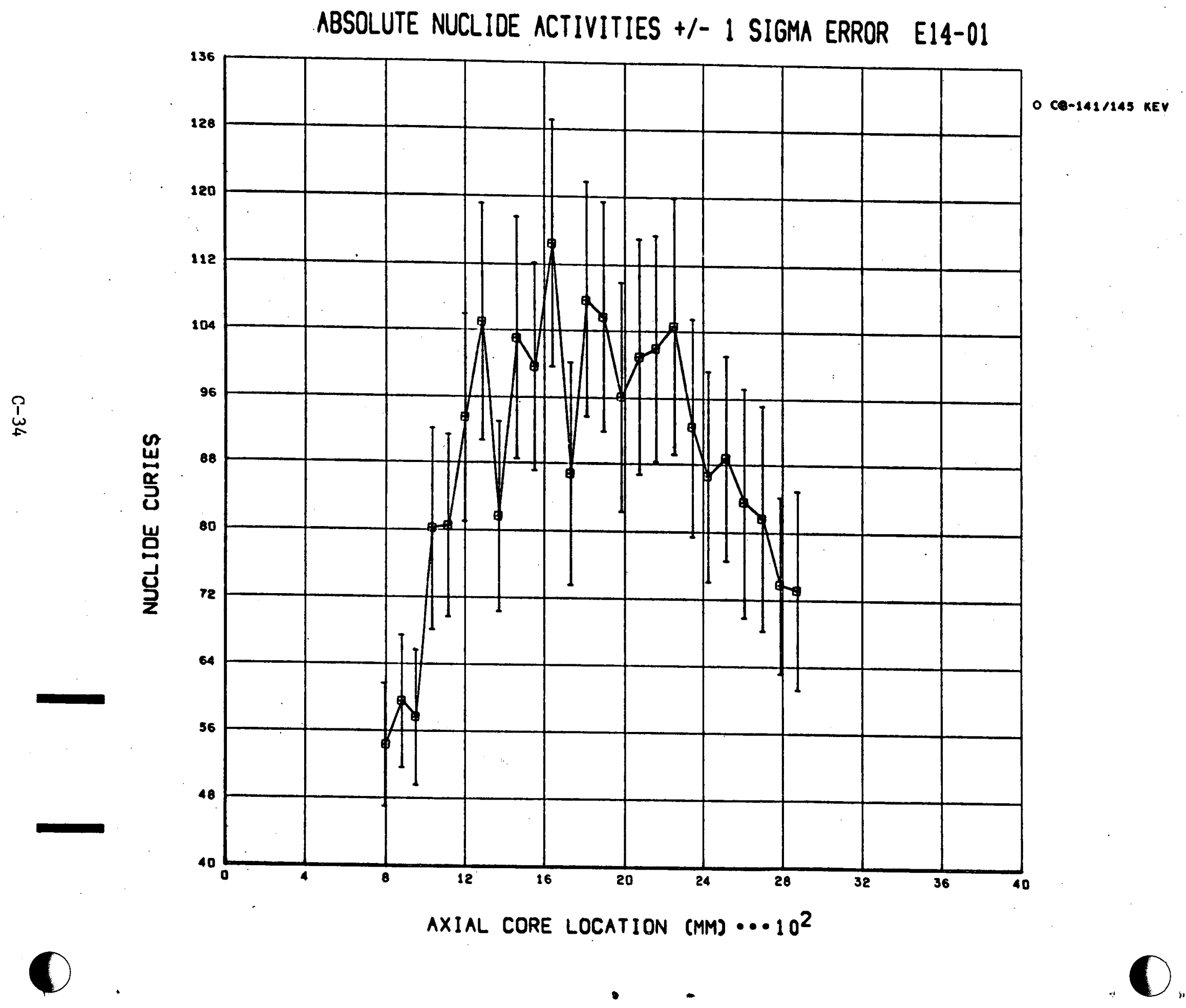


ABSOLUTE NUCLIDE ACTIVITIES +/- 1 SIGMA ERROR EI4-01

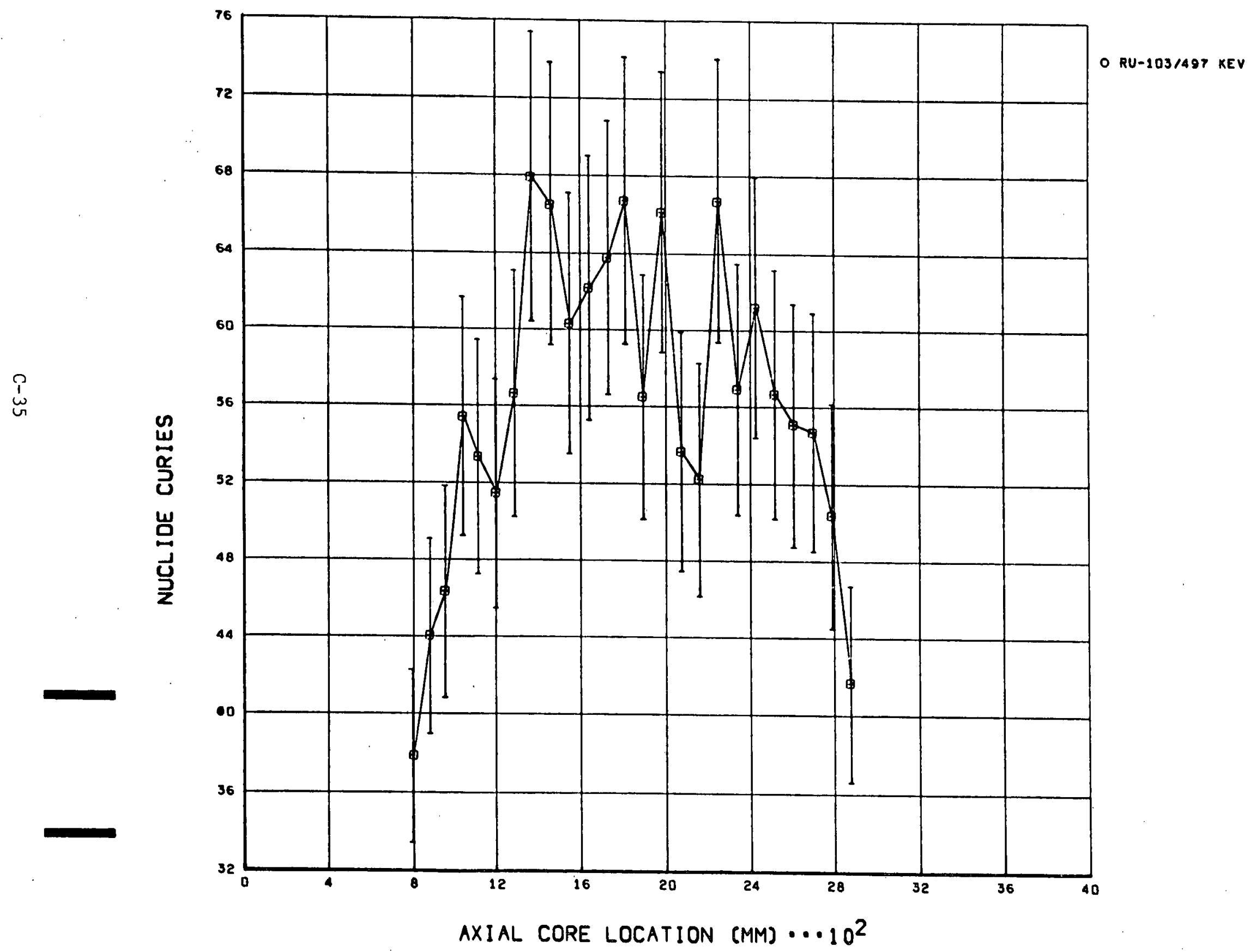




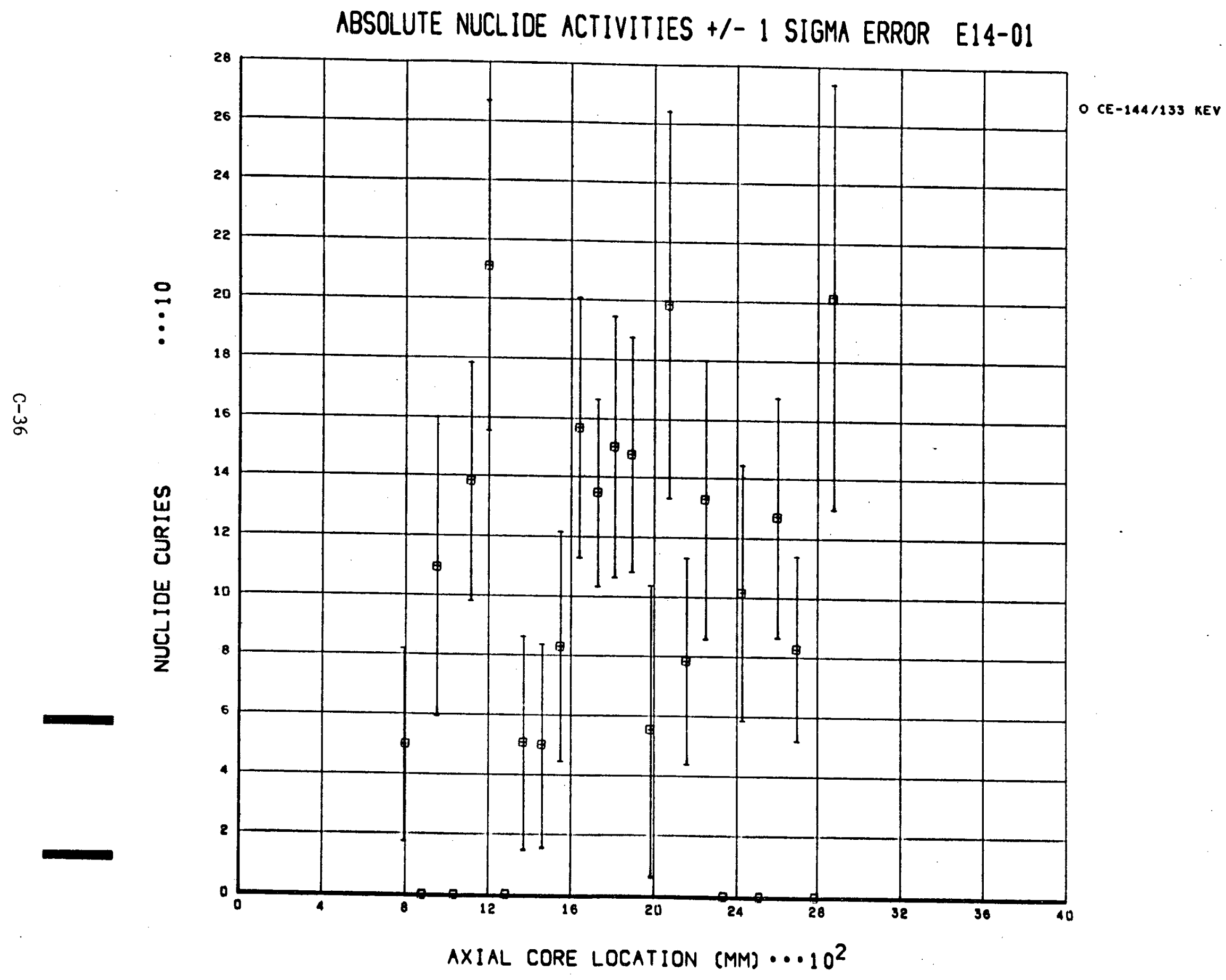

10 
ABSOLUTE NUCLIDE ACTIVITIES +/- 1 SIGMA ERROR E14-01

$\stackrel{p}{\stackrel{\omega}{w}}$

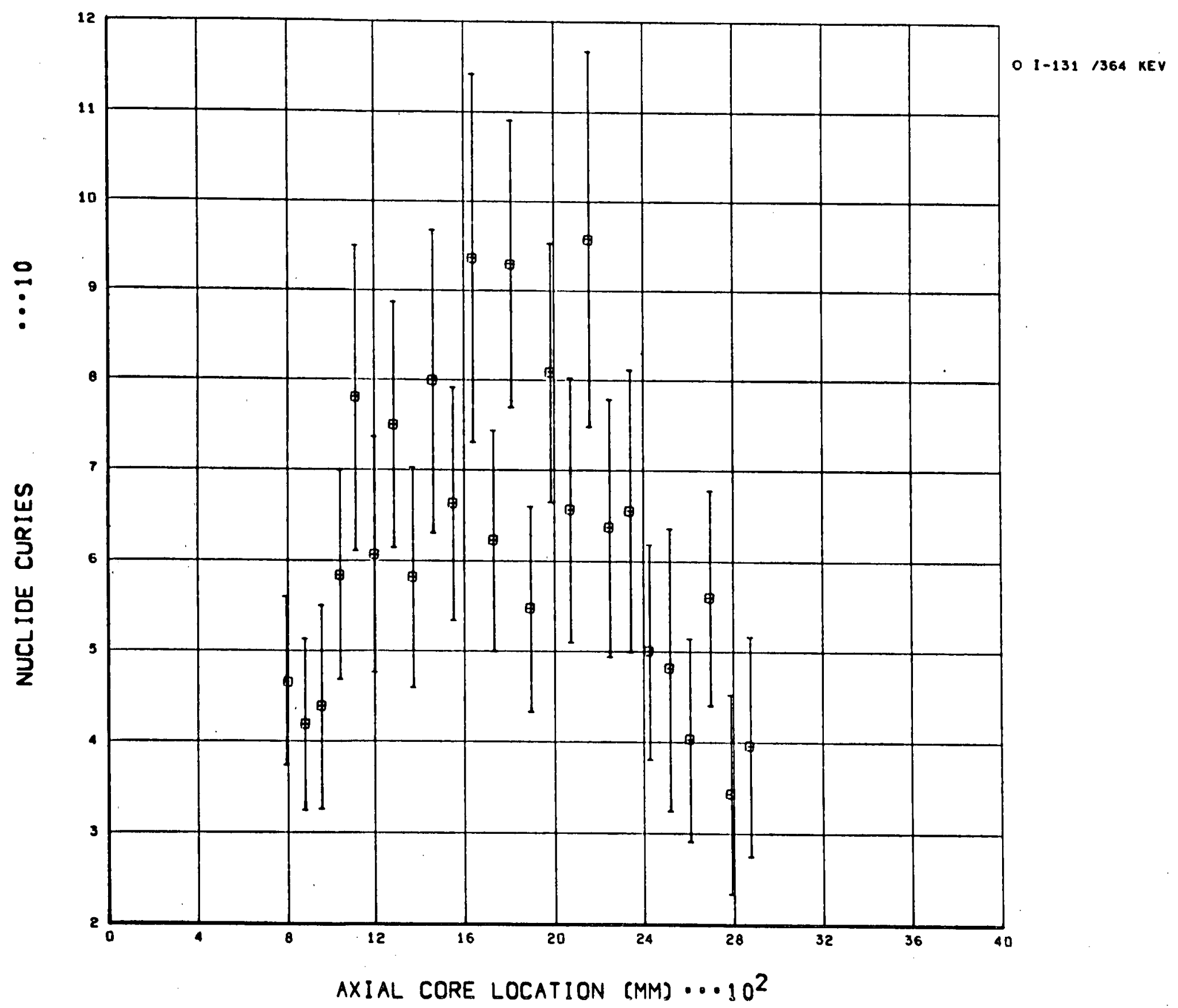




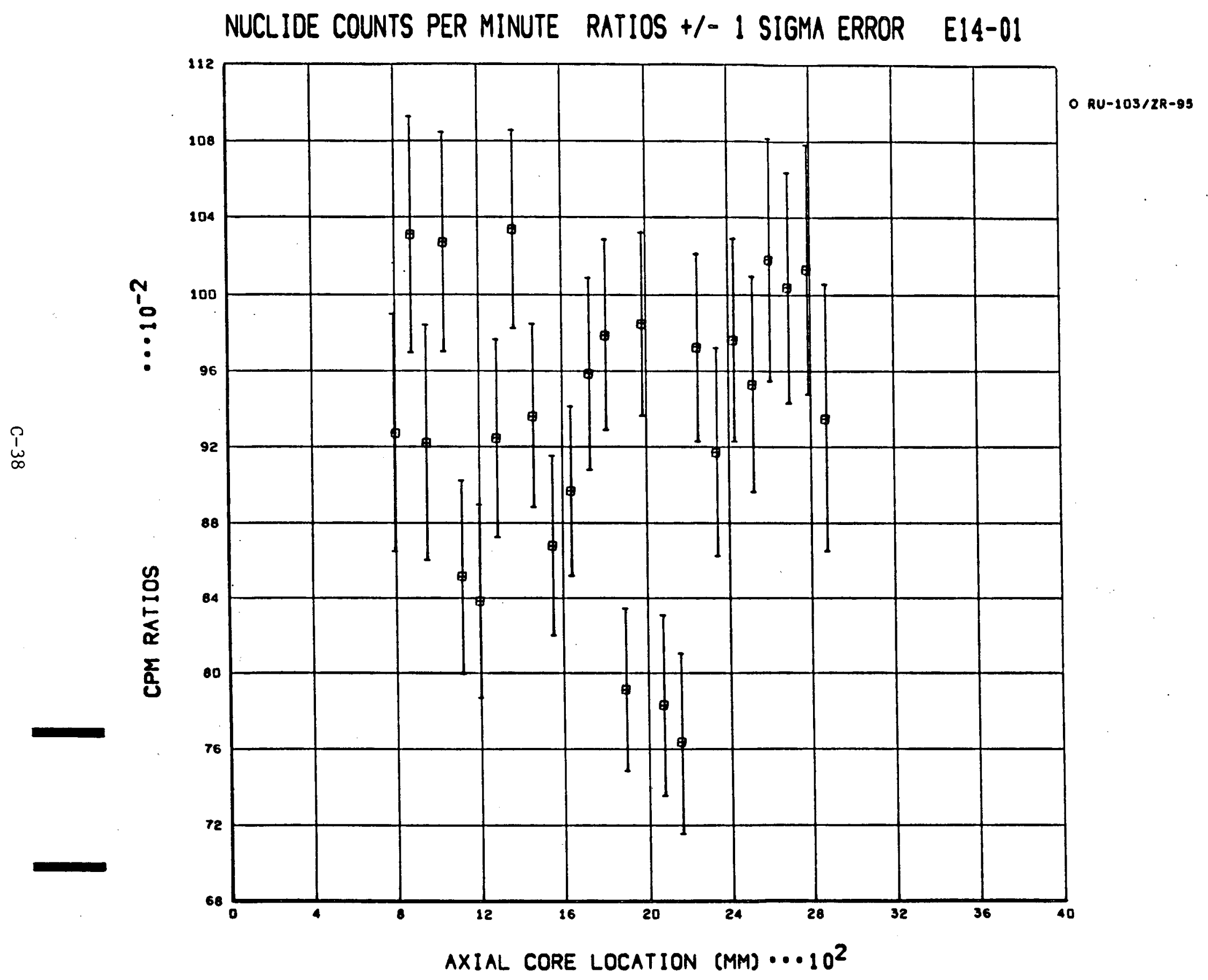


0

NUCLIDE COUNTS PER MINUTE RATIOS +/- 1 SIGMA ERROR E14-01

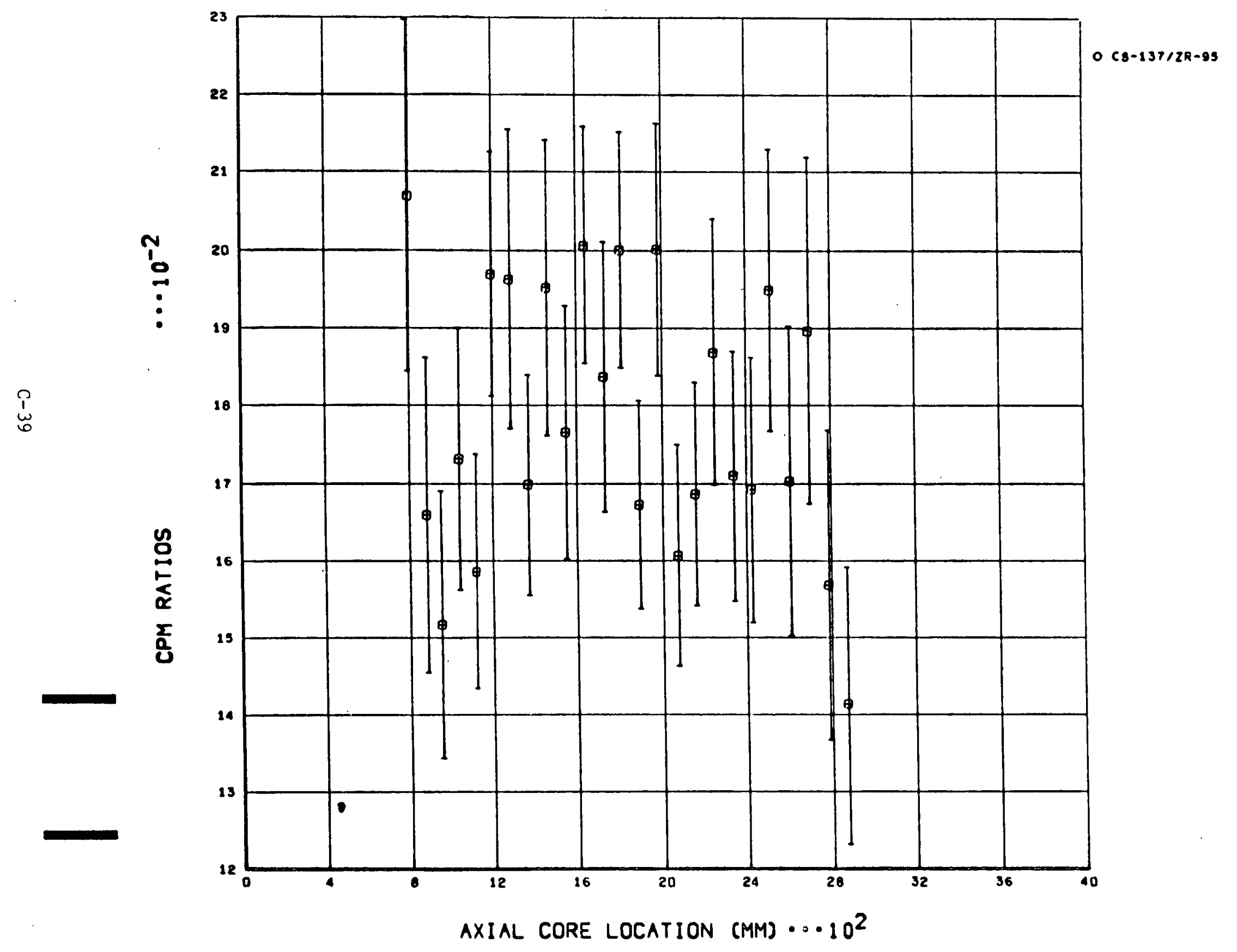




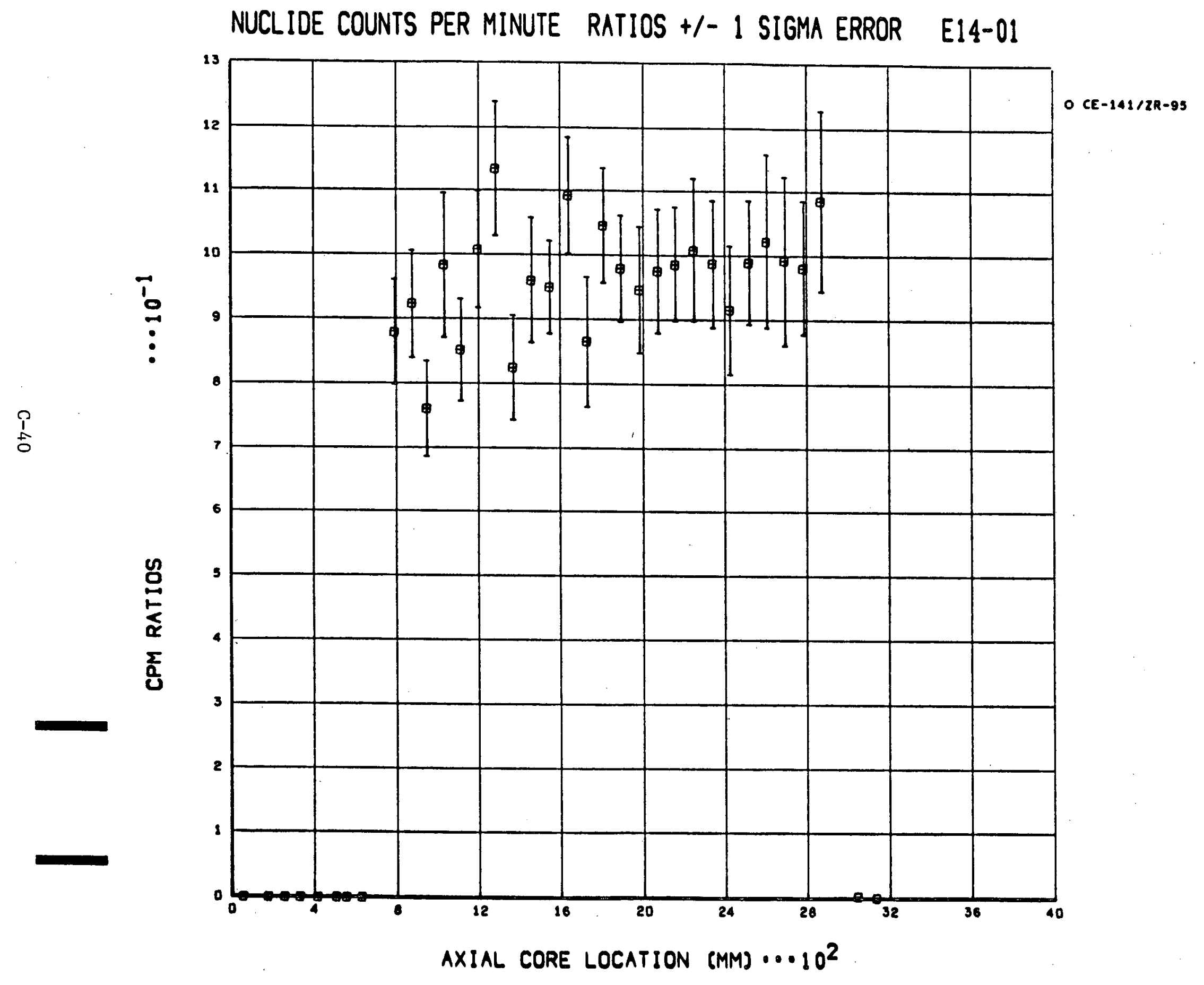

o. 
$0^{\circ}$

\section{NUCLIDE COUNTS PER MINUTE RATIOS +/- I SIGMA ERROR E14-01}

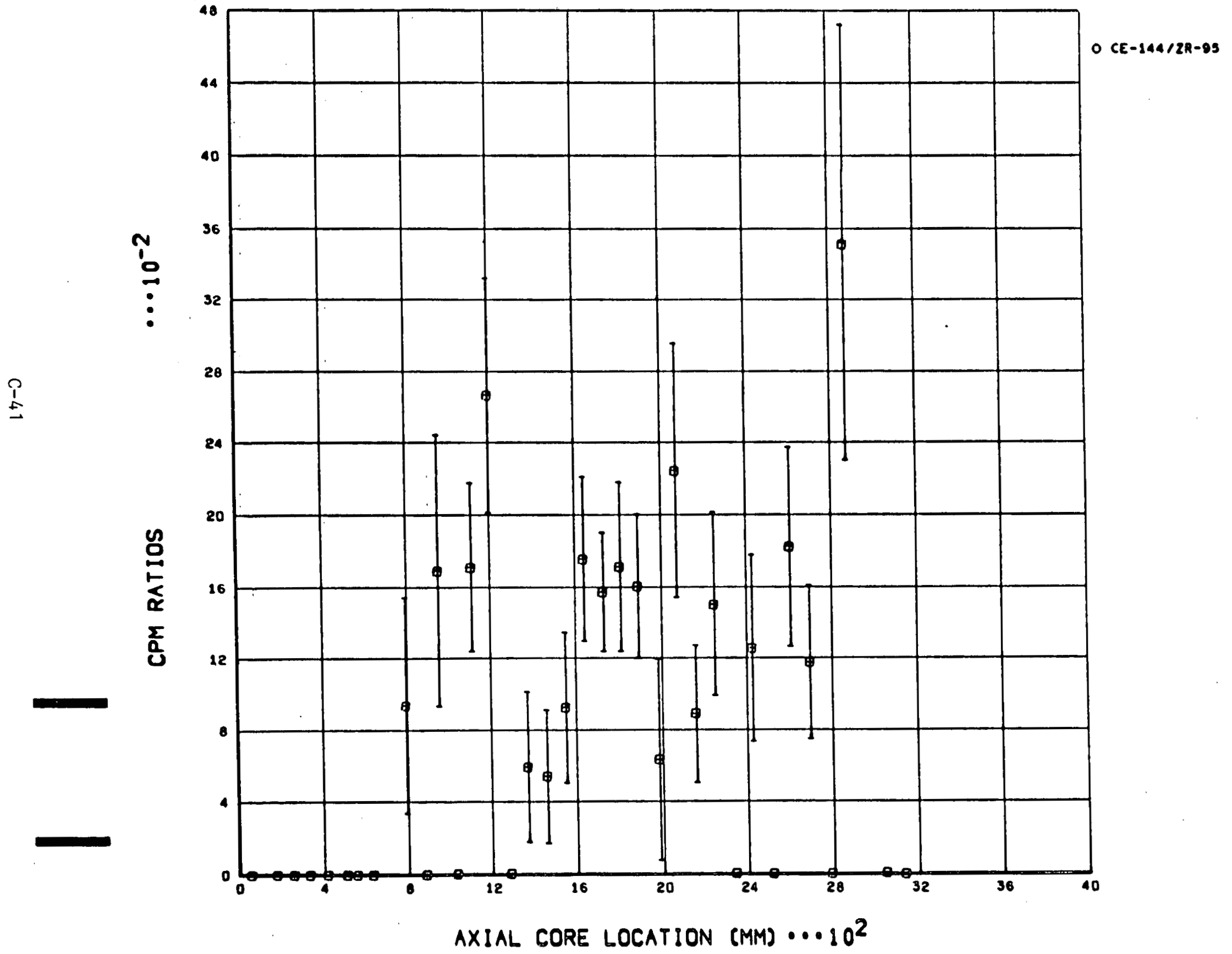




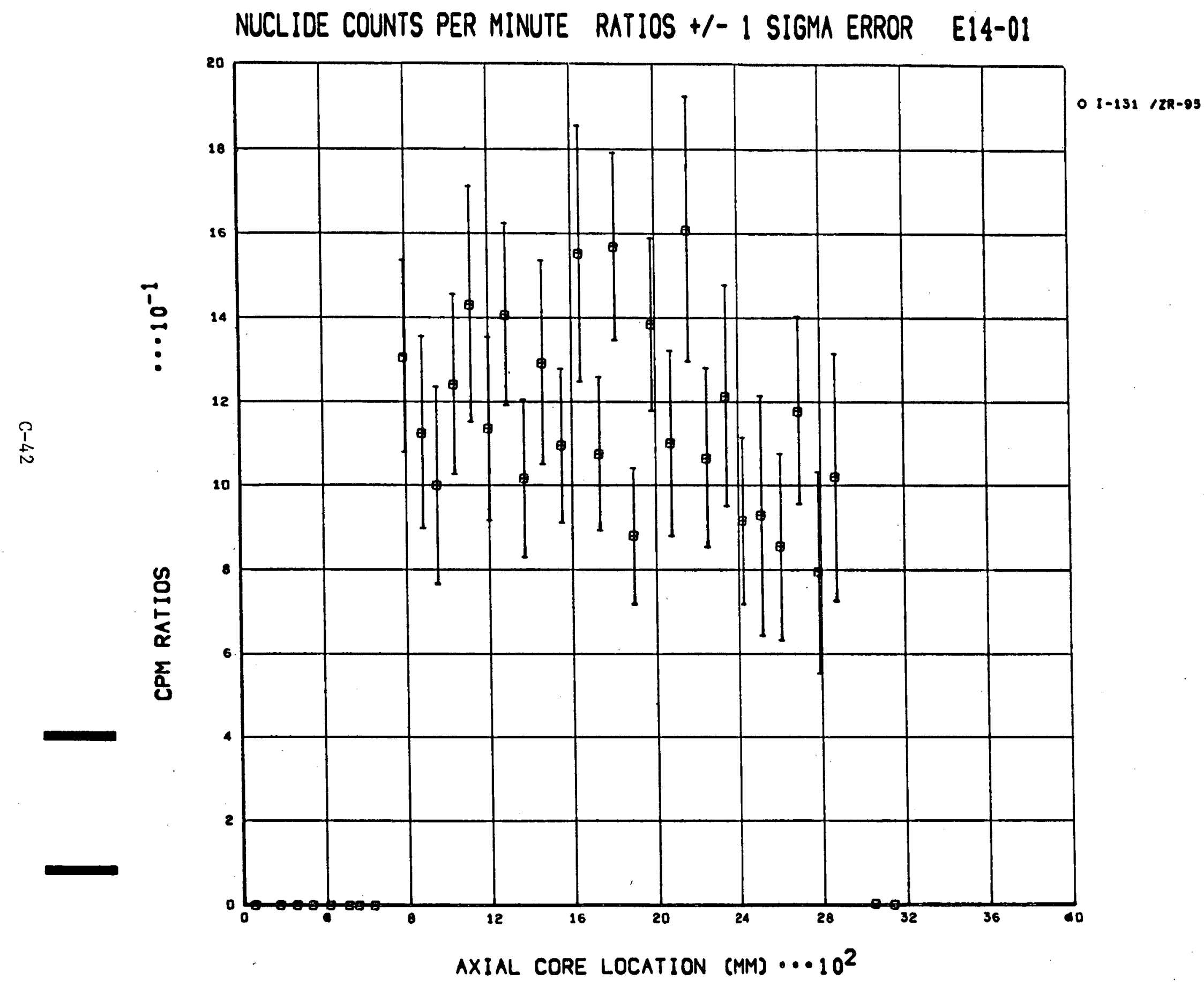

1 


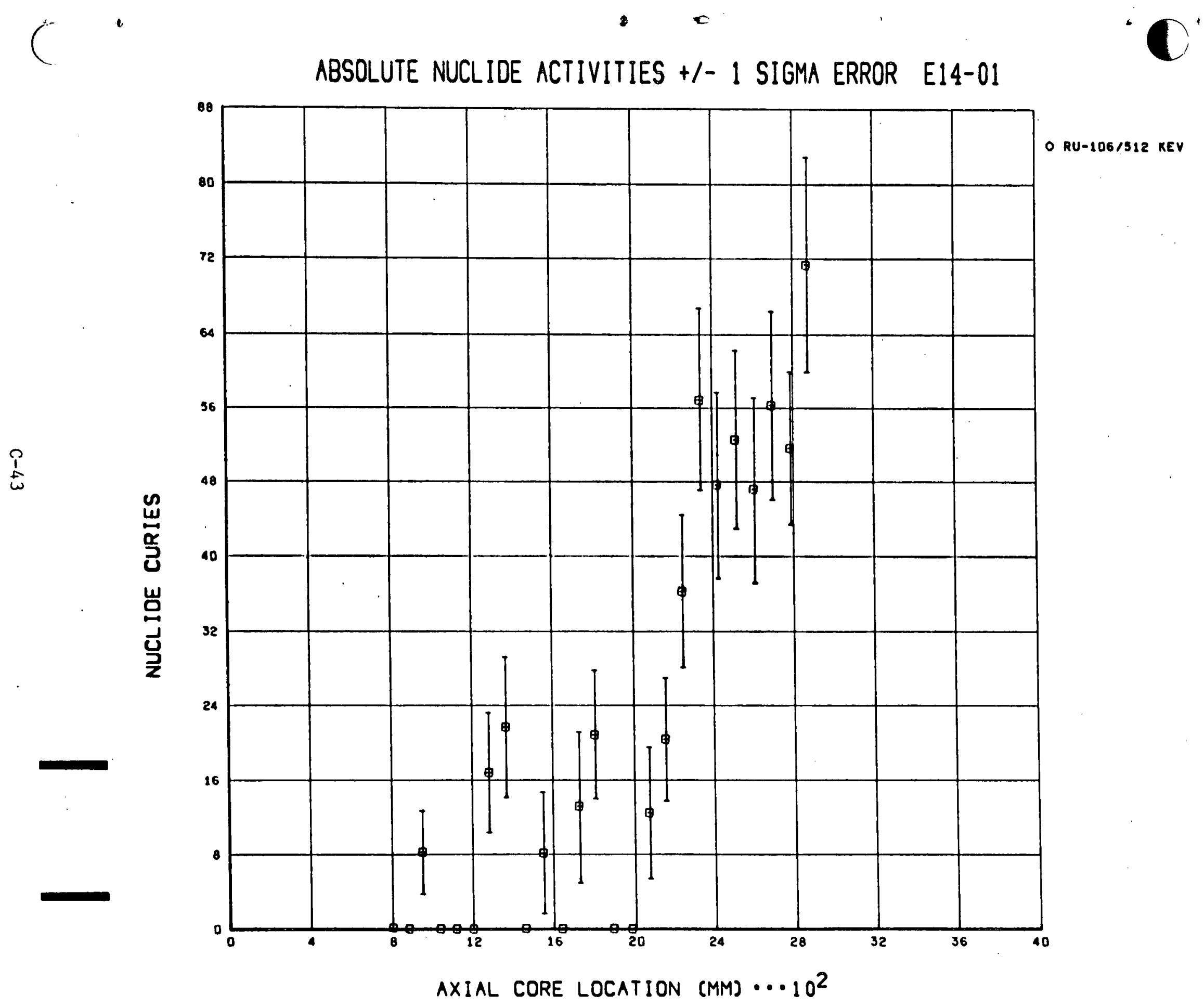




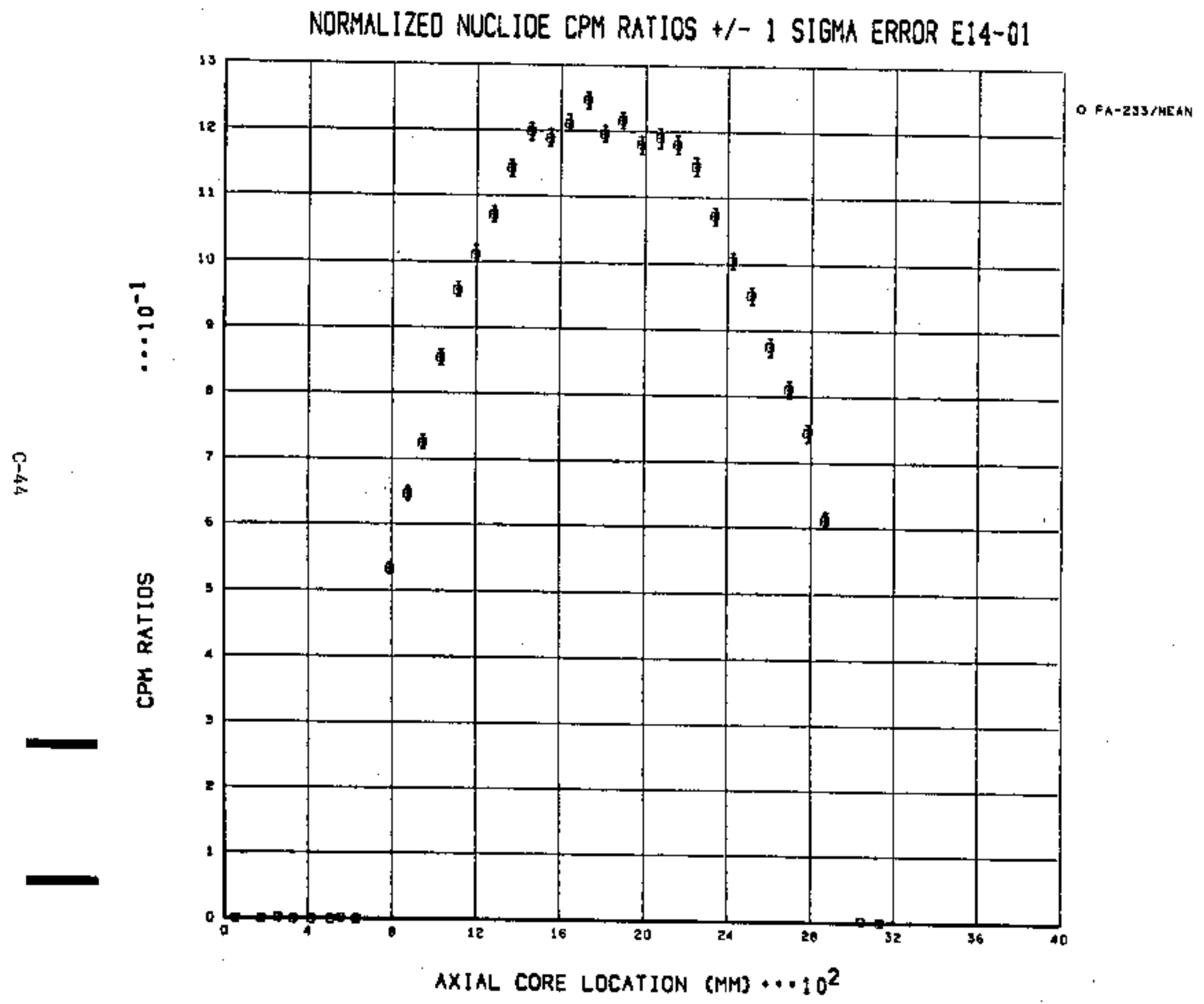




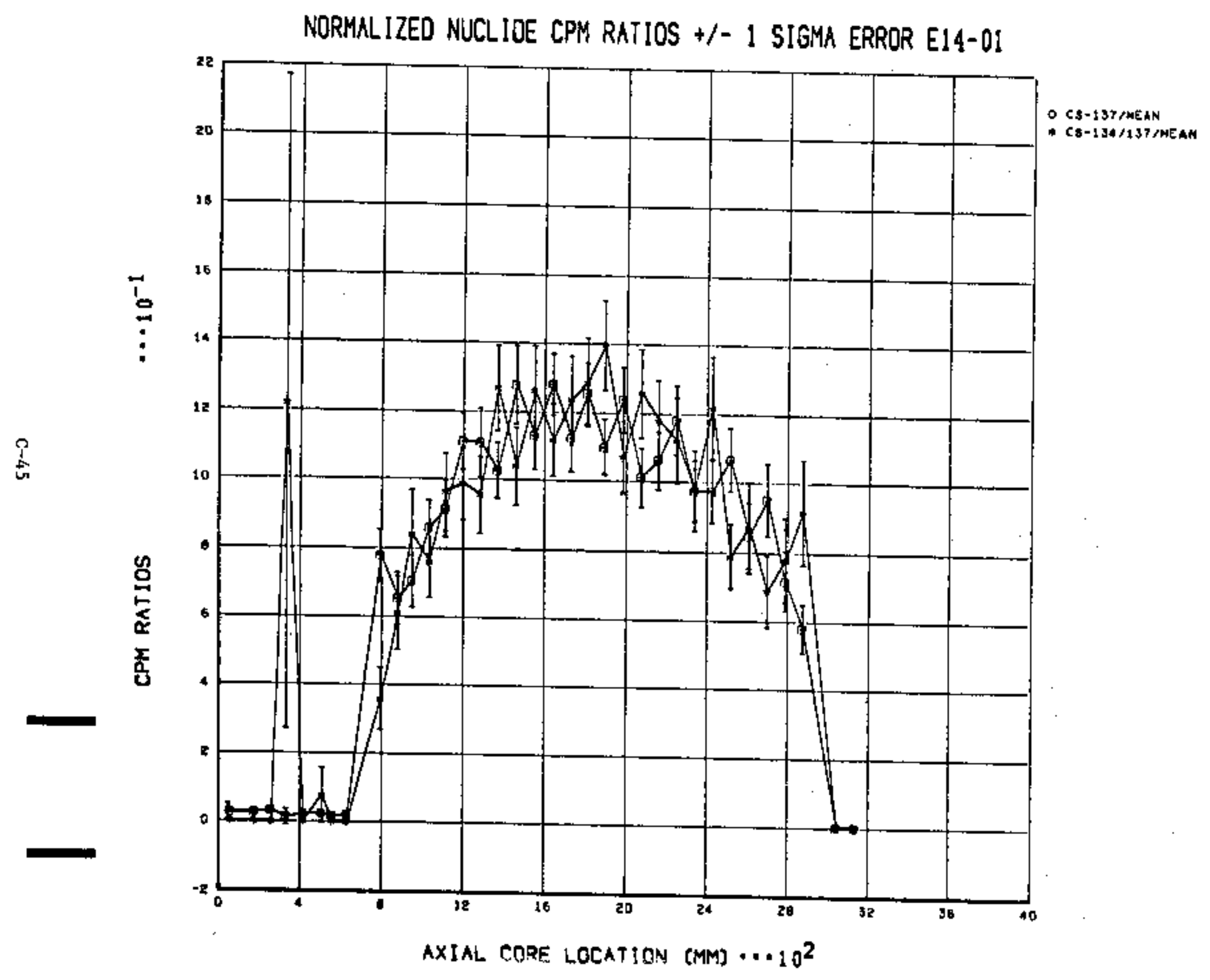




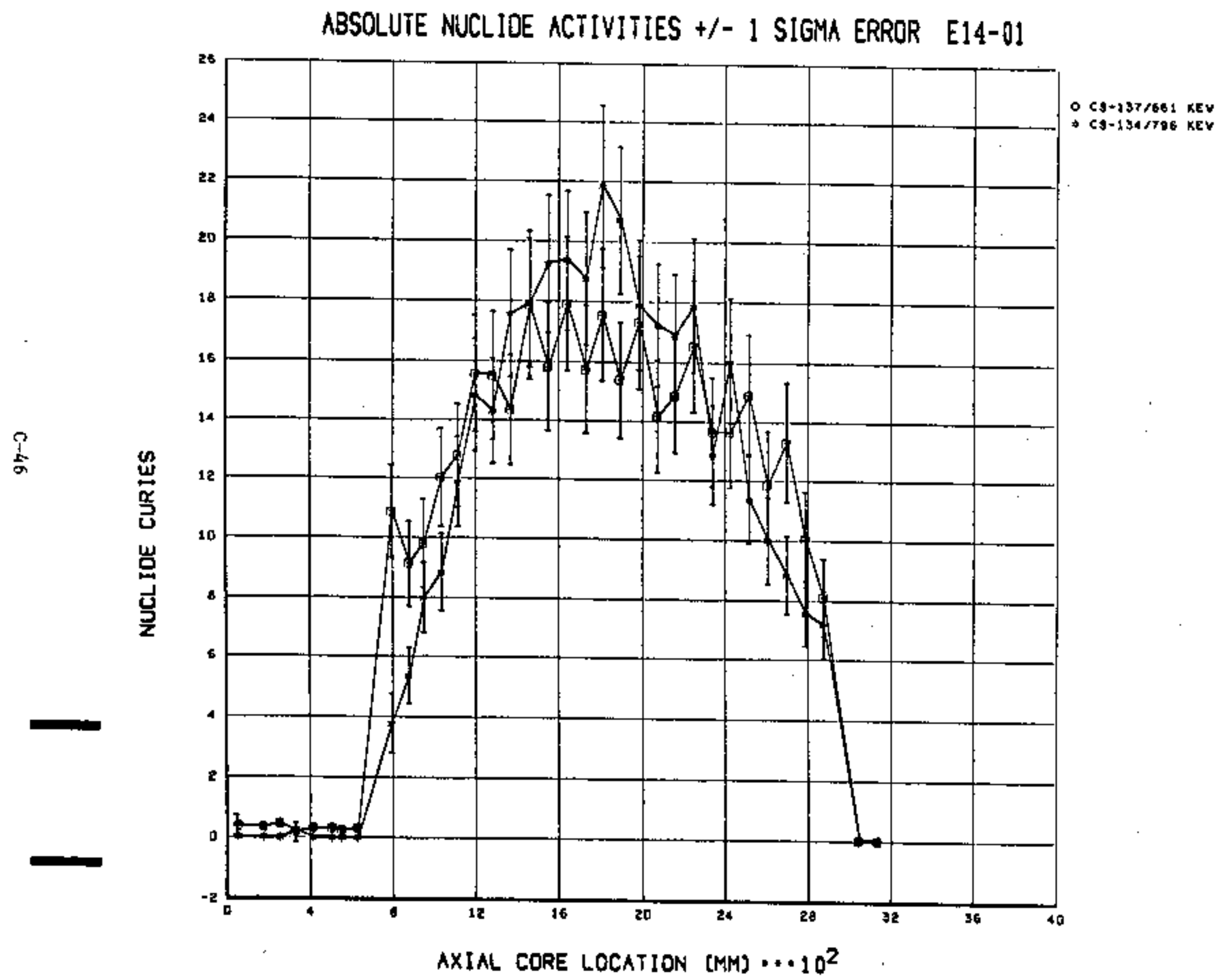




\section{NORMALIZED NUCLIDE CPM RATIOS +/- 1 SIGMA ERROR E14-01}

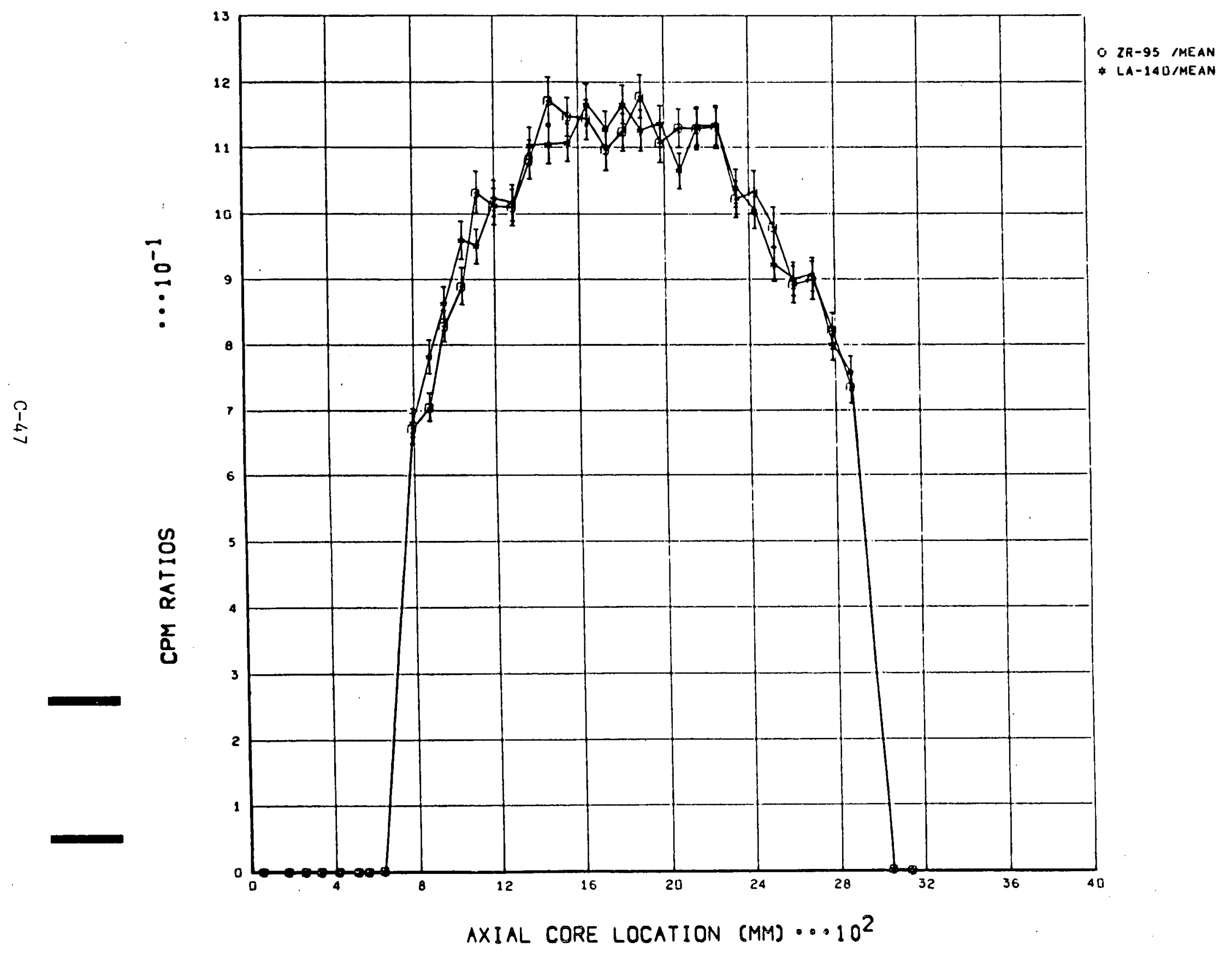




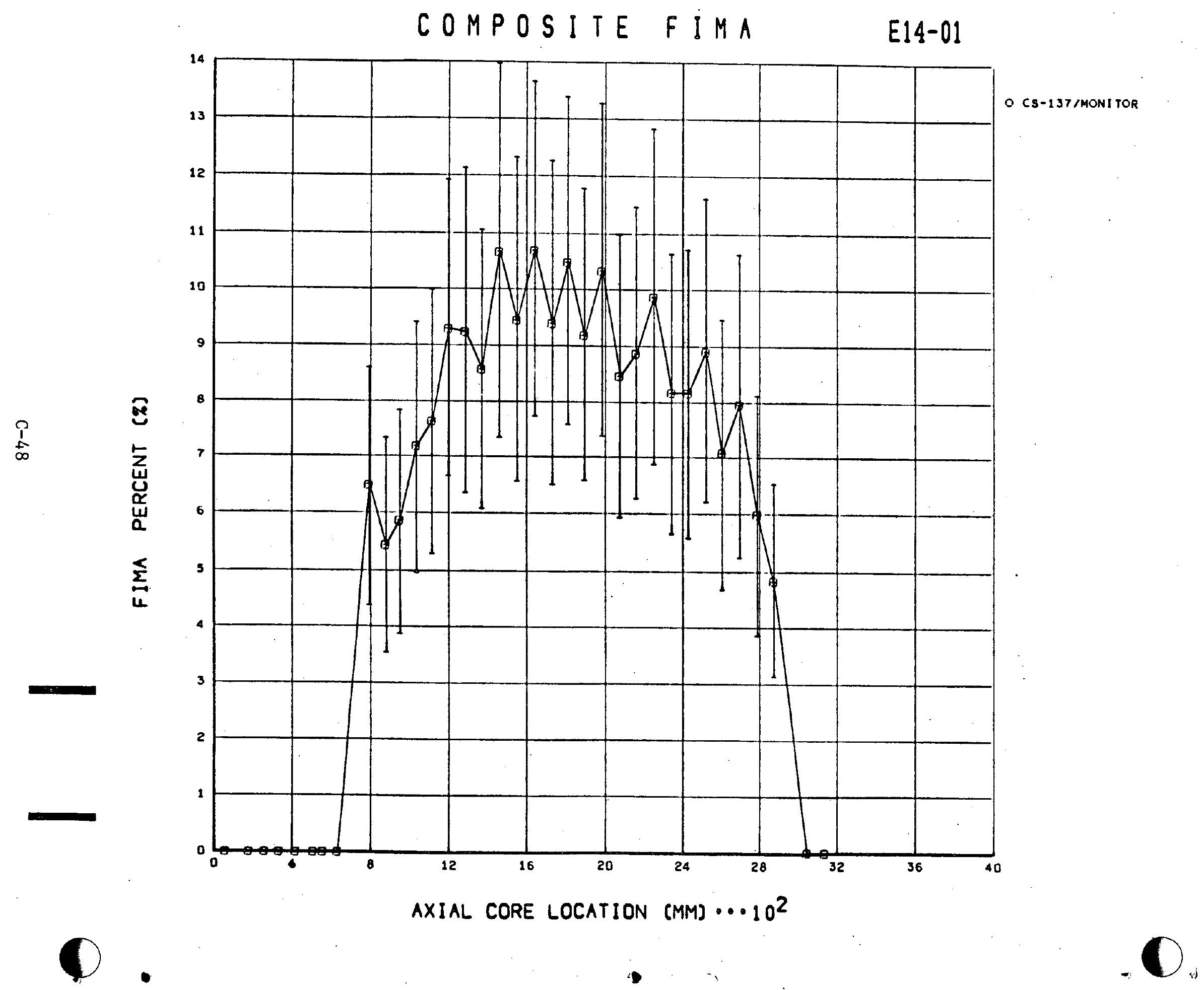

